\title{
Luiz Gastão de Castro Lima: \\ trajetória e obra de um arquiteto
}

Cristiane Kröhling Pinheiro Borges Bernardi

Orientador Prof. Dr. Renato Luiz Sobral Anelli

Universidade de São Paulo

Escola de Engenharia de São Carlos

São Carlos . 2008 
AUTORIZO A REPRODUÇÃO E DIVULGAÇÃO TOTAL OU PARCIAL DESTE TRABALHO, POR QUALQUER MEIO CONVENCIONAL OU ELETRÔNICO, PARA FINS DE ESTUDO E PESQUISA, DESDE QUE CITADA A FONTE.

Ficha catalográfica preparada pela Seção de Tratamento

da Informação do Serviço de Biblioteca - EESC/USP

Bernardi, Cristiane Kröhling Pinheiro Borges
L444L Luiz Gastão de Castro Lima : trajetória e obra de um arquiteto / Cristiane

Kröhling Pinheiro Borges Bernardi; orientador Renato Luiz Sobral Anelli. -- São Carlos, 2008.

Dissertação (Mestrado-Programa de Pós-Graduação em Arquitetura e Urbanismo e Área de Concentração em Teoria e História da Arquitetura e Urbanismo) -- Escola de Engenharia de São Carlos da Universidade de São Paulo, 2008.

1. Luiz Gastão de Castro Lima. 2. Frank Lloyd Wright. 3. Organicistas. 4. Formação profissional. 5. São Carlos. I. Título. 
FOLHA DE JULGAMENTO

Candidata: Arquiteta e Urbanista CRISTIANE KRÖHLING PINHEIRO BERNARDI

Dissertação defendida e julgada em 26/09/2008 perante a Comissão Julgadora:

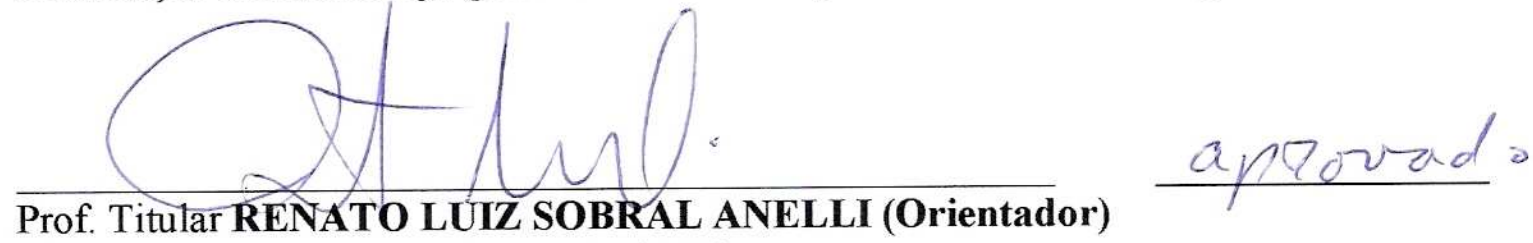

(Escola de Engenharia de São Carlos/USP)

Prof. Dr. PAULO YASSUHIDE FUЛIOKA

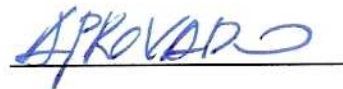

(Escola de Engenharia de São Carlos/USP)

Prof. Dr. ABÍLIO DA SILVA GUERRA NETO

(Universidade Presbiteriana Mackenzie)

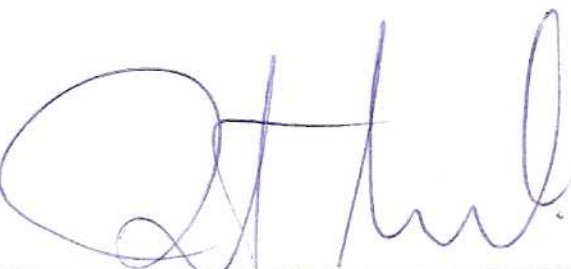

Prof. Titular RENATO LUIZ SOBRAL ANELLI

Coordenador do Programa de Pós-Graduação em Arquitetura e Urbanismo

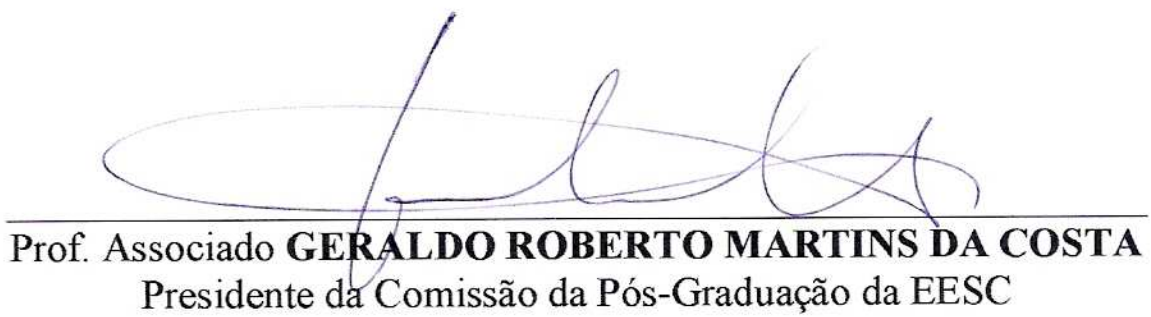




\section{Luiz Gastão de Castro Lima: trajetória e obra de um arquiteto}

Dissertação de Mestrado apresentada ao programa de Pós-graduação em Arquitetura e Urbanismo da Escola de Engenharia da Universidade de São Paulo, para obtenção do Título de Mestre em Arquitetura e Urbanismo.

Área de Concentração: Arquitetura e Urbanismo Orientador Prof. Dr. Renato Luiz Sobral Anelli

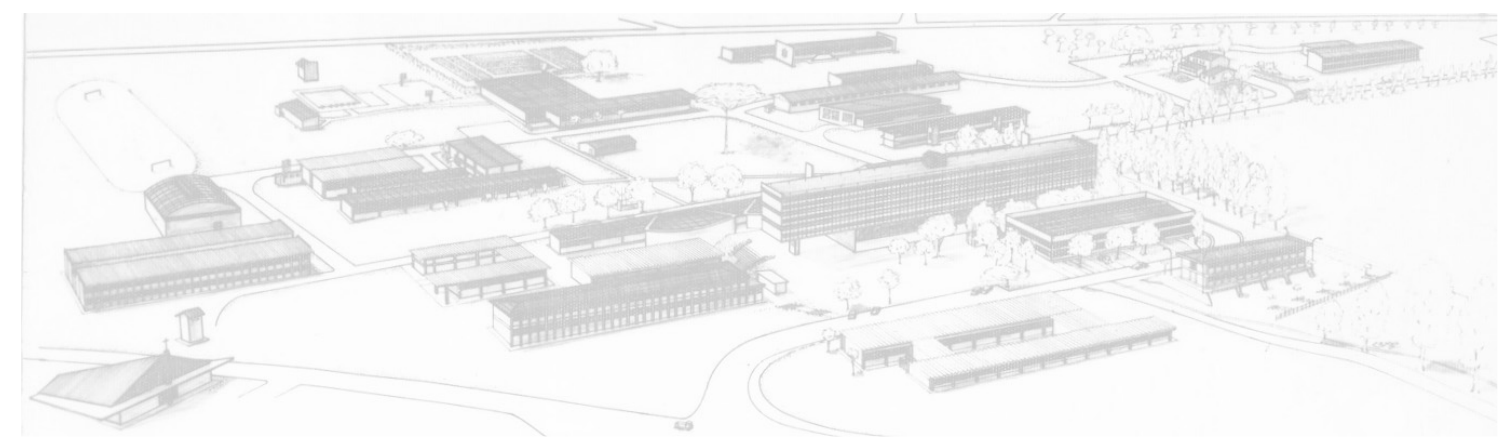


À CAPES, pela bolsa de apoio à pesquisa, de fundamental importância nos momentos finais deste trabalho, sem a qual seria impossível sua concretização.

Ao Renato, pela confiança, paciência, compreensão e pela coerente orientação que forneceu mais que bases e caminhos, tranqüilidade e liberdade para 0 desenvolvimento da pesquisa.

À banca de qualificação pela leitura atenta do Memorial, pelas colocações precisas e pela valiosa colaboração na definição de diretrizes que nos conduziram ao trabalho final.

Ao Prof Nilton Luiz Menegon, pelo cuidado com que tem guardado o acervo de Luiz Gastão de Castro Lima doado pela família, pela confiança em disponibilizá-lo para consulta e pelo empenho em abrir as portas da Universidade Federal de São Carlos para nossa pesquisa.

À Mayara e Alice, estagiárias de biblioteconomia da UFSCar que pacientemente têm trabalhado na organização do acervo.

A Antônio Perioto pela ajuda no reconhecimento das obras atribuídas ao arquiteto e a Raul Guilherme pelo tratamento e recuperação de parte do material gráfico.

A todos que concederam atenção à pesquisa nos fornecendo seu depoimento ou indicando novos rumos, em especial a Lúcio Grinover, Dácio Ottoni, Araquém Martinho, Carlos Martins, Hugo Segawa, Eduvaldo Sichieri, José Celso Contador, Jamil Sader e Alfeu Rohm.

À Sibele Fausto da biblioteca da FAU-USP, Helena da biblioteca da EESC-USP, Michelle Tito da Fundação Pró Memória de São Caetano do Sul e Natália Leoni do arquivo histórico Wanda Svevo da Fundação Bienal de São Paulo.

À família do arquiteto pelo constante incentivo e, de forma especial, à Flávia (Lae), Bruno, Marília, Bau e Maria Helena.

À Prof ${ }^{\mathrm{a}}$ Maria Ângela Bortolucci pela amizade, carinho, apoio e pelas esclarecedoras declarações.

À Prof ${ }^{\underline{a}}$ Sheyla Serra e à arquiteta Maria Zarria pela amizade e camaradagem nos momentos cruciais dessa pesquisa.

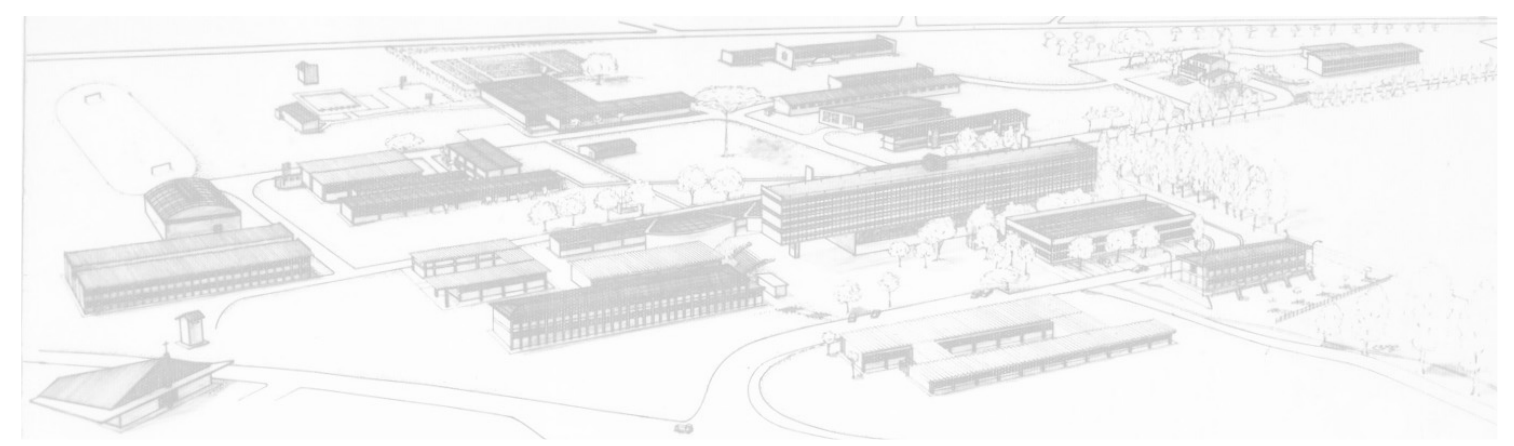


Aos colegas do IAB-São Carlos que desde o início, quando este trabalho era apenas um remoto projeto de pesquisa, incentivaram e apoiaram incondicionalmente: Regina Dória, Elisabeth Bottamedi, Reginaldo Peronti e Luciano Buttignon.

Ao arquiteto Júlio César Alves Ferreira por disponibilizar fotos de seu acervo pessoal e à Mirian Nava pela revisão do abstract.

À Thera, Kiza e Rafaela pela amizade sincera.

Ao Beto por tudo, em especial pela Amizade, Fidelidade, Paciência, cumplicidade e companheirismo ao compartilhar comigo do mesmo propósito.

Ao Lucas, Ana Júlia e Thiago, por tudo que têm me ensinado e por compreenderem minhas ausências durante vários momentos desse trabalho.

E ao Dr Celso Charuri,

Pai, Mestre, Amigo eterno, que me mostrou a razão de tudo isso e a quem rendo as mais elevadas homenagens.

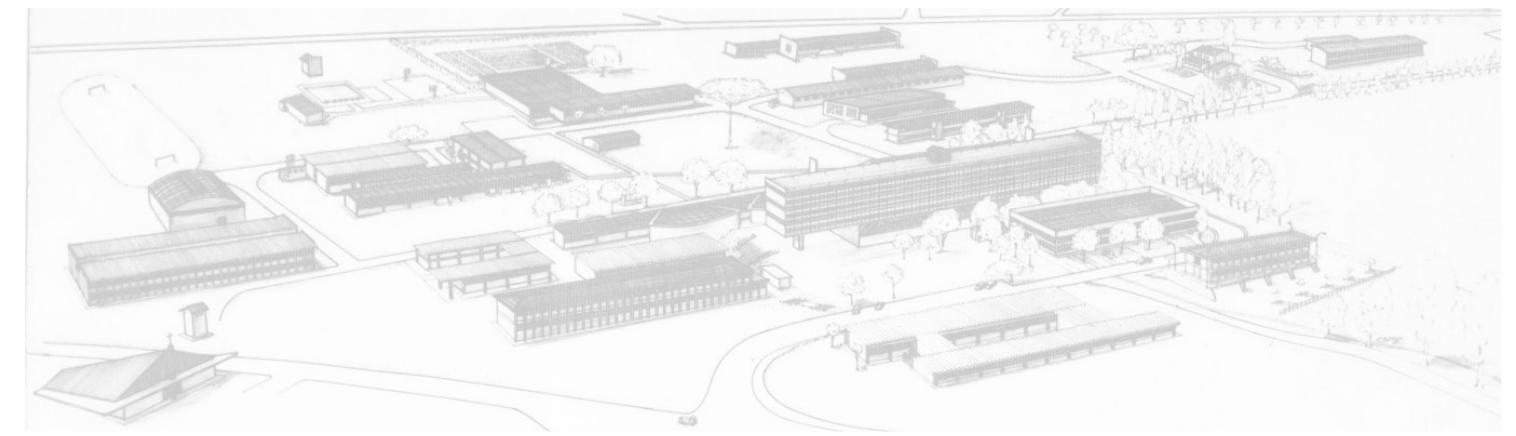




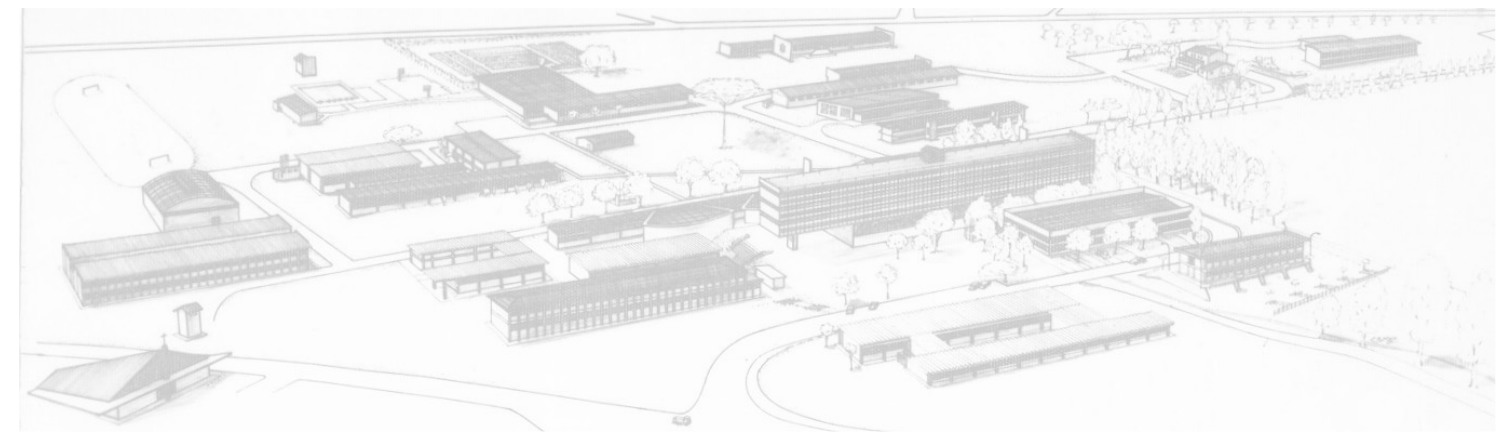


Iniciamos essa pesquisa em 2005, a partir do ingresso no Programa de Pósgraduação em Teoria e História da Arquitetura, da Escola de Engenharia da Universidade de São Paulo, em São Carlos.

Em março deste mesmo ano, ocorreu o falecimento de meu pai.

Exatos dois anos depois, em março de 2007, minha mãe também veio a falecer.

Eu não poderia simplesmente dedicar a eles este trabalho, sem agradecer profundamente a orientação que me deram durante todas as minhas escolhas profissionais.

A meu pai Marílio (in memoriam) pela paixão pela arquitetura e pelo empenho em me direcionar neste caminho

E à minha mãe Maria Esther (in memoriam) pelo exemplo de dedicação ao trabalho e à docência. 
BERNARDI, C.K.P.B. (2008). Luiz Gastão de Castro Lima: trajetória e obra de um arquiteto. $235 \mathrm{f}$. Dissertação (Mestrado) -Escola de Engenharia de São Carlos, Universidade de São Paulo, São Carlos, 2008.

Desde a década de 50, o ensino de Arquitetura em São Paulo enfocou uma grande discussão de valores éticos e estéticos, tendo como centro difusor a Faculdade de Arquitetura da USP e como principal articulador Vilanova Artigas. $\mathrm{Na}$ época, duas linhas se divergiam no âmbito do discurso arquitetônico, dentro e fora da Universidade: Os racionalistas e os organicistas, ou como costumavam se declarar, os "corbusianos" e os "wrightianos". Os dois grupos geraram no seio da discussão moderna nacional, debates interessantes que foram muitas vezes além do aspecto arquitetônico. Entre os declaradamente wrightianos estava o jovem Luiz Gastão de Castro Lima, formado pela FAU-USP em 1954, depois de ter cursado dois anos na Politécnica. A recuperação de sua produção acadêmica e arquitetônica, ainda que pautada na experiência relativa de uma trajetória individual, é capaz de ilustrar uma parte da história da arquitetura que ficou por muito tempo às margens da historiografia.

Palavras-chave: 1. Luiz Gastão de Castro Lima. 2. Frank Lloyd Wright. 3. Organicistas. 4. Formação profissional. 5. São Carlos. 
BERNARDI, C.K.P.B. (2008). Luiz Gastão de Castro Lima: A biography of an architect. $235 \mathrm{f}$. Dissertation (Mestrado) - Escola de Engenharia de São Carlos, Universidade de São Paulo, São Carlos, 2008.

Since the 50's, the teaching of Architecture in Sao Paulo has focused on a broad discussion of ethical and aesthetic values, having as its diffuser centre the Faculty of Architecture and Urbanism of Sao Paulo (FAU-USP), and as its main articulator Vilanova Artigas. At the time, two streams used to have different ideas about the architectural discourse: the "racionalistas" and "organicistas", or as they used to call themselves, "corbusianos" and "wrightianos". The discussions generated by these two groups have sometimes gone beyond the architectural aspect. Among the "wrightianos" was Luiz Gastão de Castro Lima, who graduated by FAU-USP in 1954 after two years studying at Polytechnic School. The recovery of his academic and architectural production is able to illustrate a part of the history of architecture that was, for a long time, kept on the edge of historiography.

Keywords: 1. Luiz Gastão de Castro Lima. 2. Frank Lloyd Wright. 3. Organicistas. 4. professional carrer. 5. São Carlos. 
ASCORAL - Assembléia de Construtores para uma Renovação Arquitetônica

AUH - Departamento de História da Arquitetura e Estética do Projeto da Faculdade de Arquitetura e Urbanismo da Universidade de São Paulo

CBT - Companhia Brasileira de Tratores

CENA - Centro de Energia Nuclear

CENEMA - Centro de Estudos de Solos do Instituto de Genética da ESALQ

CEF - Centro de Estudos Folclóricos

CFE - Conselho Federal de Educação

CIAM - Congresso Internacional de Arquitetura Moderna

CPD - Centro de Processamento de dados

CTR - Departamento de Cinema, Teatro, Rádio e Televisão da Escola de Comunicação e Artes da Universidade de São Paulo

ECA - Escola de Comunicação e Artes da Universidade de São Paulo

EESC - Escola de Engenharia de São Carlos

ENBA - Escola Nacional de Belas Artes

ESALQ - Escola Superior de Agricultura Luiz de Queiroz

FAAC - Faculdade de Arquitetura, Artes e Comunicação da Universidade Estadual Paulista FAU ou FAU-USP- Faculdade de Arquitetura e Urbanismo da USP

Fundusp - Fundo de Construção da Cidade Universitária Armando Salles de Oliveira GFAU - Grêmio da Faculdade de Arquitetura e Urbanismo da Universidade de São Paulo LIEP - Laboratório Integrado Engenharia de Produção da Universidade Federal de São Carlos

MES - Ministério da Educação e Saúde

PERT - Program Evaluation and Review Technique

POLI - Escola Politécnica

SAMBRA - Sociedade Anônima de Mármores do Brasil

SAP - Departamento de Arquitetura da Escola de Engenharia de São Carlos

USP - Universidade de São Paulo

UFSCar - Universidade Federal de São Carlos

UNB - Universidade de Brasília

UNESP - Universidade Estadual Paulista 


\section{RESUMO}

\section{ABSTRACT}

INTRODUÇÃO

PARTEI - FORMAÇÃO

Origens.. 20

Anos 30: desenho de uma modernidade .24

As mudanças na ENBA .25

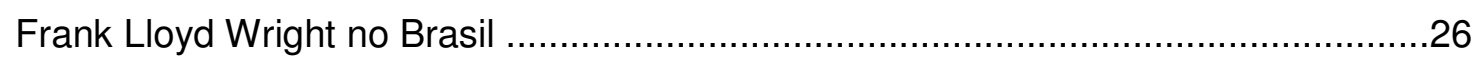

Anos 40: revisão crítica do projeto moderno .......................................................28

Arquitetura moderna no Brasil: entre o orgânico e o racional .....................................31

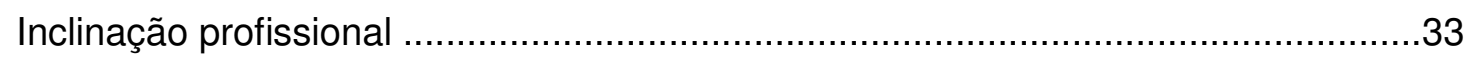

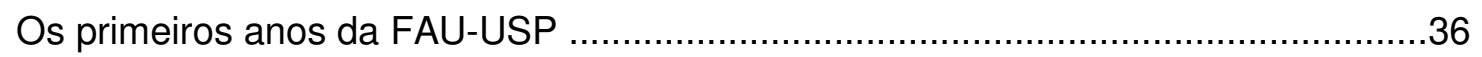

O Folclore e as origens remotas do AUH .......................................................40

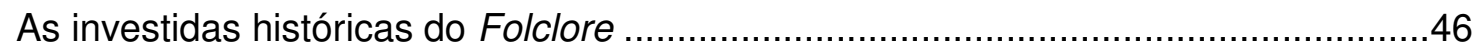

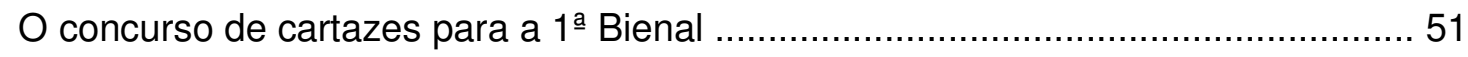

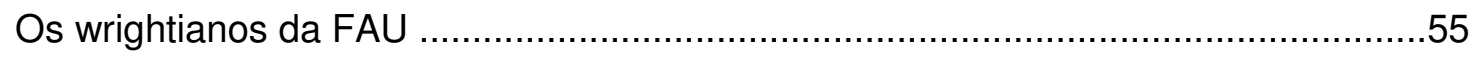

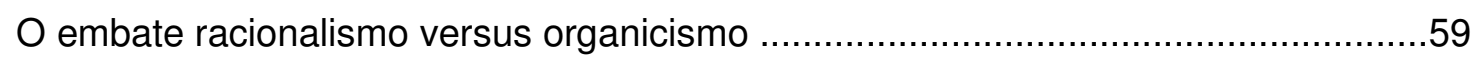

PARTE II - PRIMEIROS PASSOS

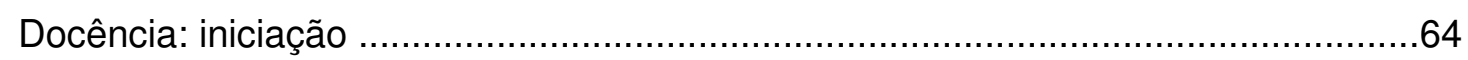

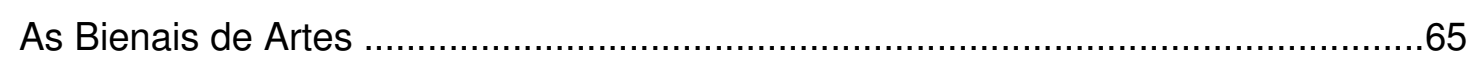

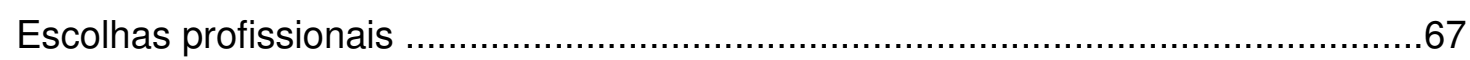

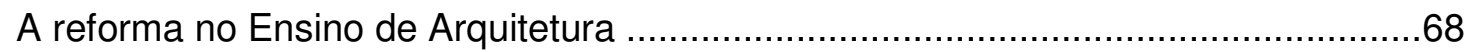

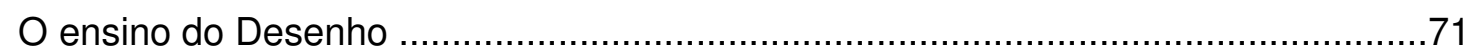

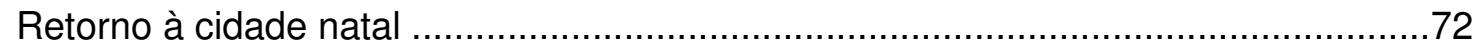

Os edifícios da EESC e o Governo Carvalho Pinto ...............................................77

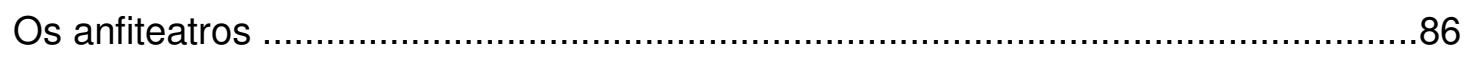

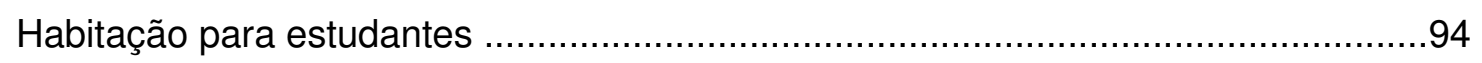

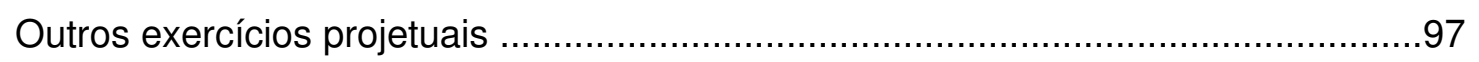

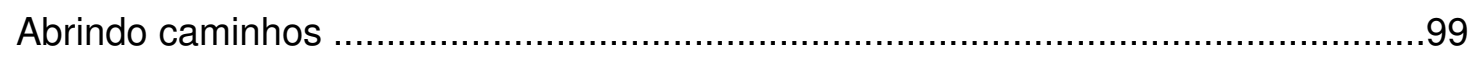

Diamantul (1964) e Wirth Latina (1977) …........................................................ 102

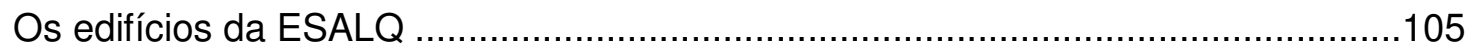




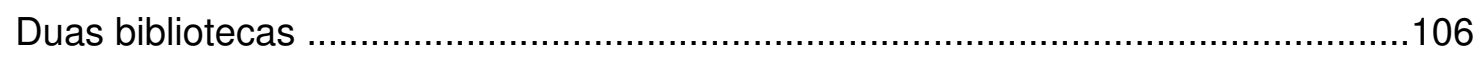

CENA

PARTE III - ABRINDO CAMINHOS

Residência Wilson Senise (1966) ......................................................................120

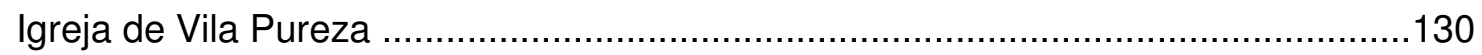

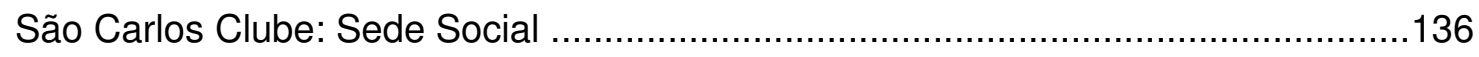

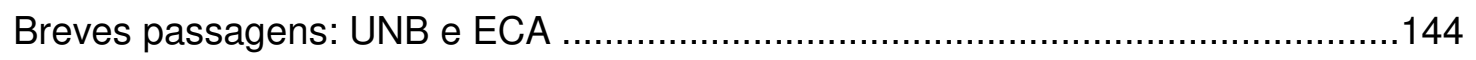

A organização de uma metodologia de trabalho e ensino .......................................148

A criação do SAP e o Mestrado em Industrialização da Construção ........................153

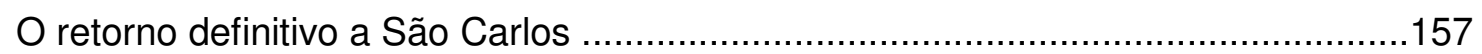

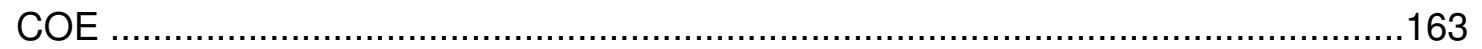

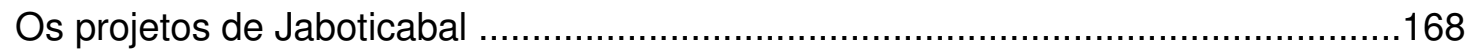

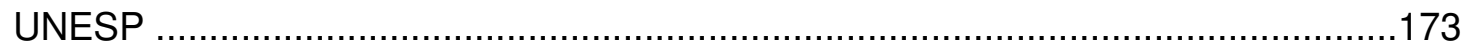

A Universidade Federal de São Carlos e o LIEP ...............................................174

PARTEIV - SEDIMENTAÇÃO

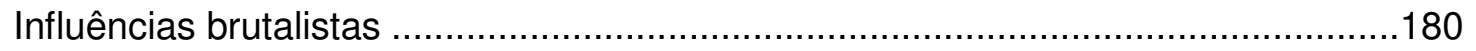

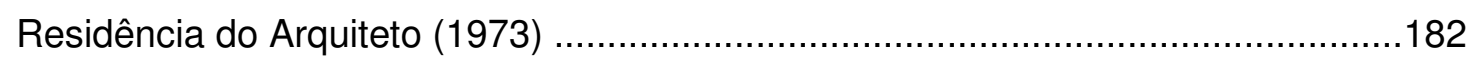

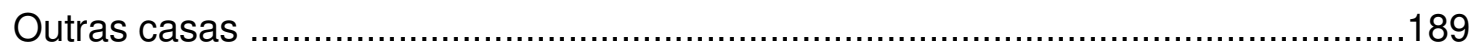

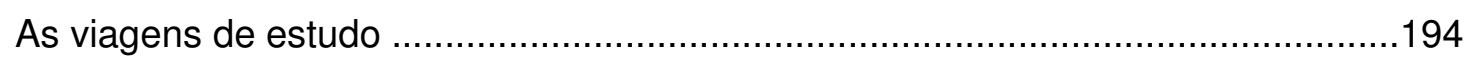

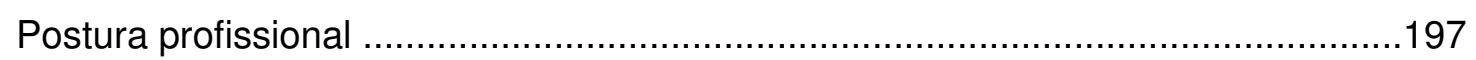

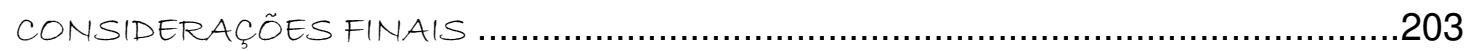

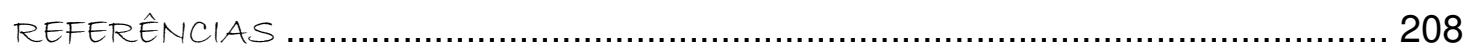

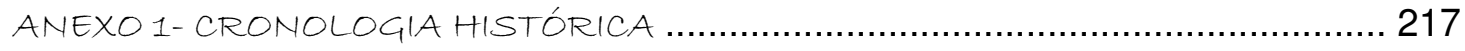

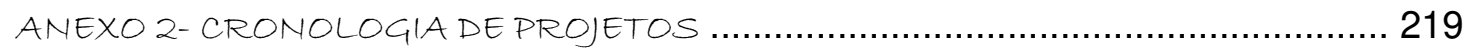

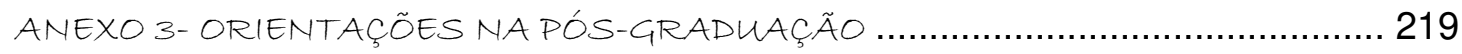



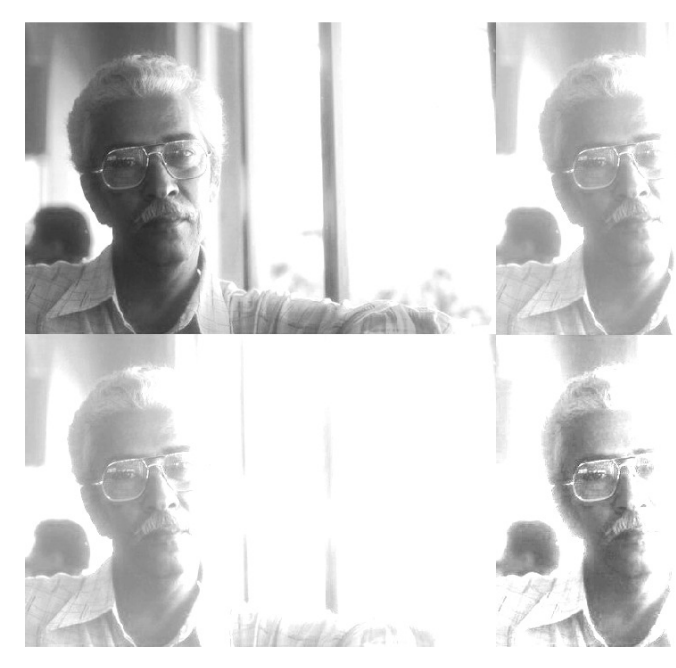

INTRODUÇÃO

A história da arquitetura moderna brasileira tem se construído tanto de acontecimentos e fatos de grande repercussão, como de ações silenciosas. A contribuição destes menos conhecidos, mas nem por isso profissionais menores, tem se mostrado tão fundamental como as outras associadas a nomes de peso, marcadas por obras de referência.

Devido seu ineditismo, como primeiro trabalho acadêmico sobre a obra de Luiz Gastão de Castro Lima, essa pesquisa acaba por encerrar além da história de um arquiteto, também parte da história da arquitetura que se revela em sua trajetória. Por esta e outras razões, acreditamos que nenhum fato deva ser negligenciado, pensamento este que nos conduziu a um trabalho sem recortes.

Ao iniciarmos a pesquisa nos deparamos com a escassez de material iconográfico e com a dissolução da documentação da produção do arquiteto. Grande parte de seu acervo pessoal foi doado a colaboradores e em muitos casos, os desenhos se perderam.

Tão fragmentadas e igualmente escassas são as suas publicações. Das várias palestras e cursos que 
ministrou, praticamente não houve registro. No entanto, sua atuação como docente extrapolou muitas vezes os limites de um professor. Localizamos alguns textos e relatórios que não constavam em documentos oficiais nem tão pouco, eram mencionados no currículo do arquiteto. Este material por vezes, foi referência para novas investigações.

Luiz Gastão de Castro Lima teve uma atuação muito prolífica como orientador, abrangendo as áreas tecnológica, histórica e urbanística. Orientou temas dos mais diversos, indo desde história da arquitetura colonial, da arquitetura moderna, urbanismo, sistemas estruturais e construtivos, arquitetura ecológica, acessibilidade, gestão de projetos, comunicação visual, tecnologia da informação, dentre outros. Também orientou profissionais oriundos de cursos distintos da Arquitetura, como Terapia Ocupacional, Engenharia de Produção, Artes e Filosofia.

Realizou inúmeros projetos em várias cidades como Bauru, Birigui, Botucatu, Mogi das Cruzes, Araraquara, São Caetano do Sul, São João da Boa Vista, São Paulo, Trabiju, Guaira, Jaboticabal, Piracicaba, Manaus e mais de uma centena de residências só na cidade de São Carlos. Algumas destas obras haviam sido publicadas sem fazer menção ao arquiteto, ou por vezes, dadas como material apócrifo.

Ao longo da pesquisa identificamos mais de noventa projetos com sua participação, não apenas de arquitetura, mas também de paisagismo, planejamento, design industrial, acústica, estruturas de concreto e comunicação visual. Para descobrir e identificar estas obras, a pesquisa revestiu-se de um caráter investigatório que não imaginávamos de início. Com base principalmente em depoimentos, tratamos de investigar a 
veracidade das informações, percorrendo toda e qualquer pista, por mais remota que fosse.

Um fator recorrente nas entrevistas nos chamou a atenção: todas as pessoas com quem conversamos que trabalharam ou conviveram com Luiz Gastão de Castro Lima se dirigiam ao arquiteto com profundo respeito e admiração. Admiração pelo homem, humanista, cativante e admiração pelo profissional, competente, integral.

Essa é uma história construída de fatos e relatos. E como todo relato, tem seus atos falhos, delineados pelos limites da memória e pelo passar do tempo. Iniciamos nossa pesquisa resgatando dados de quem conviveu com o arquiteto. Juntando minúsculas peças começamos a montar uma imagem, por vezes extremamente complexa, por outras demasiado simples.

Luiz Gastão de Castro Lima vivenciou momentos históricos de consolidação da arquitetura moderna no Brasil. Foi professor, pesquisador e arquiteto pioneiro no interior do estado de São Paulo. Grande interessado nas tecnologias de ponta, em suas aplicações na arquitetura e nos meios de representação gráfica, sabia que a arte maior seria ainda mais sutil e elevada através da conciliação da ciência com a criatividade.

Adepto às teorias wrightianas, fez parte da segunda turma da FAU-USP participando do embate racionalismo versus organicismo que toma corpo no meio acadêmico no início dos anos 50.

A recuperação da produção acadêmica e arquitetônica de um profissional como Luiz Gastão de Castro Lima, ainda que pautada na experiência relativa de uma trajetória individual, é capaz de ilustrar uma parte da história da arquitetura que ficou por muito tempo às margens da historiografia. 
Este trabalho, por mais fôlego que se proponha ter, não dá conta de toda a produção do arquiteto. É fato consciente que muitas lacunas ainda se deixarão preencher por trabalhos posteriores.

A narração dessa trajetória compõe o mosaico de uma história maior, encenada também por outros personagens singulares, ainda por serem apresentados.

A dissertação se distribui em quatro partes: Formação, Primeiros Passos, Abrindo caminhos e Sedimentação, e por se tratarem de uma trajetória se organizam de forma cronológica.

A primeira, Formação busca traçar o perfil do arquiteto, das suas origens aos primeiros passos na vida profissional. Retrata os primeiros momentos da Faculdade de Arquitetura e Urbanismo da Universidade de São Paulo (FAU-USP). Documenta momentos históricos vivenciados no seio da Universidade, em épocas de intensa discussão acerca da arquitetura brasileira e dos debates entre adeptos de Frank Lloyd Wright e Le Corbusier.

Primeiros Passos tece os caminhos percorridos pelo arquiteto, desde o início de sua vida docente, passando pela FAU-USP - onde atuou por dezesseis anos - pelas experiências na Escola de Engenharia de São Carlos (EESC-USP) e na Escola Superior de Agricultura Luis de Queiroz (ESALQ). Apresenta os primeiros projetos institucionais e procura compreender suas preocupações e objetivos como arquiteto e educador.

Abrindo caminhos, busca à luz do pensamento orgânico, interpretar de que forma se materializa em suas 
obras uma arquitetura moderna de expressão wrightiana. Relata as breves passagens pela Universidade de Brasília (UNB), pela Escola de Comunicação e Artes (ECA) e pela Faculdade de Arquitetura, Artes e Comunicação (FAAC) da UNESP em Bauru. Revela uma nova fase na carreira do arquiteto, marcada pelo desligamento com a FAU e pelo retorno definitivo a São Carlos, no momento de implantação da Pós-graduação na Escola de Engenharia e de constituição do departamento de Arquitetura e Planejamento.

E por fim, Sedimentação analisa as referências brutalistas em sua obra a partir da análise da residência do arquiteto e narra seus últimos momentos como educador.

Toda narrativa é entremeada de acontecimentos onde se revelam os amigos, as escolhas profissionais e os projetos.

Um dilema nos acompanhou durante a elaboração do texto. Como fazer referência ao "Professor Gastão" sem ferir os modelos acadêmicos que nos levavam a atribuir o sobrenome à figura?

"Lima" ou "Castro Lima" engessaram o texto. Por vezes mudamos e reformulamos o tratamento, mas em momento algum isso nos conduziu à imagem de um sujeito de gosto refinado, mas de hábitos simples.

Contrariamos nesse trabalho a formalidade acadêmica, assumindo os riscos e efeitos de nossa decisão. Nas páginas que se seguem, faremos referência a Luiz Gastão de Castro Lima como "Gastão" ou "Luiz Gastão", como era conhecido no meio acadêmico e profissional e como foi lembrado saudosamente por todos que privaram de seu convívio. 
A MEMÓRIA TEMISSO DE BONITO.

tOdA histórla é UMA fICÇÃO E tOdA nOSSA MEMÓRIA É UMA FICÇÃO.

nós realmente montamos as imagens que QUEREMOS VER.

às Vezes até as imagens que precisamos Ver indiVIDUALMENTE, e ás Vezes até as imaGens QUEPRECISAMOS VER COLETIVAMENTE.

queremos que a histórla seja ASSIM E ESCREVEMOS A HISTÓRIA BUSCANDO SER SEMPRE MAISEMELHOR.

ás vezes são 'OS caras' que tiveram maiores resultados e essas chamam-se histórias de VENCEDORES.

Ás VEzES SÃO 'OS CARAs' que tiveram MENOREs resultados e essas são histórlas mais SIMPLES, MAS ABSOLUTAMENTE RELEVANTES.

E NESSA FICÇÃO, EU ACHO UMA MARAVILHA ESSA QUESTÃODA MEMÓRIA.

EUNÃO SEI SE APRESENTEI O GASTÃO.

- que eU qUERIA APRESENTAR é cOMO nós FORMAMOS UMA ESPÉCIEDE TECIDO.

DESDE A PRIMEIRA PRANCHETA, NO PRIMEIRO DIA DE aUla na faU até hOJE, EU VENHO ME MISTURANDO NUM TECIDO ONDE ESTAVAM TODOS E UM DOS FIOS ERA O GASTÃO. 
Luiz Gastão de Castro Lima: trajetória e obra de um arquiteto

19

I -FORMAÇÃO

$$
\text { FORMAÇÃO }
$$

1 LIMA (199?)

Apresentação de Luiz Gastão de Castro Lima feita pelo arquiteto Jorge Caron durante uma aula dada no

Departamento de Arquitetura da EESC- USP, s/d Arquivo CEDOC. Aula gravada em vídeo.

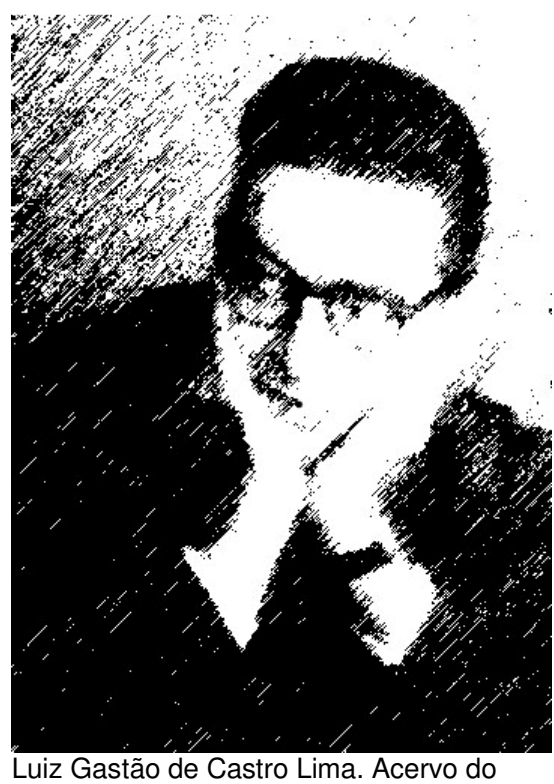

Arquiteto. Foto tratada pela autora 
Luiz Gastão de Castro Lima nasceu em São Carlos, interior paulista, em 7 de outubro de 1927 e faleceu em 3 de dezembro de 2003, aos 76 anos de idade.

Arquiteto, professor, pesquisador, fez parte de uma geração que viveu momentos históricos na Faculdade de Arquitetura e Urbanismo da USP dos anos 50. Filho de Iracema de Castro Lima e Renato de Castro Lima, fazia questão de afirmar ter nascido em São Carlos "por acaso".

O pai, advogado, atuou como delegado de polícia no Vale do Paraíba, Araçatuba, Rio Claro e em diversas cidades do estado de São Paulo, até vir para São Carlos em 1927. "O pai do Gastão era um intelectual, gostava muito de escrever". ${ }^{2}$ A mãe era carioca e "por influência dela, Gastão tinha até um jeito de falar meio 'acariocado". 3

Depois de alguns anos vivendo em São Carlos, a família Castro Lima se transfere para a capital. Apesar da mudança ainda em tenra idade, o vínculo com a cidade não se rompe totalmente, pois Luiz Gastão continua a passar férias no interior.

A esta altura, um edifício onde o pai havia

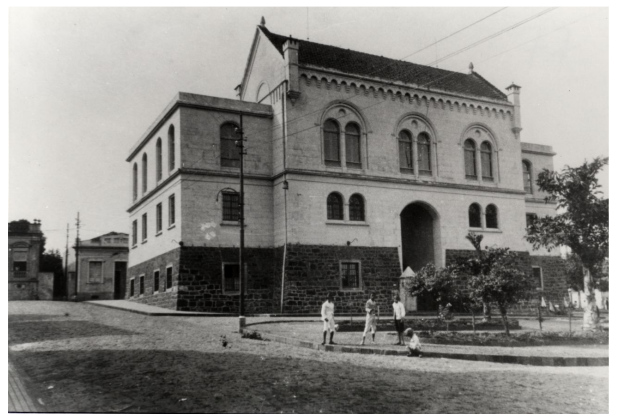

Antigo Fórum e Cadeia pública de São Carlos. Atual Câmara dos Vereadores. Fonte: Fundação Pró Memória de São Carlos trabalhado como delegado vinha despertando a atenção do jovem Luiz Gastão. Projetado por Victor Dubugras e construído por Euclides da Cunha, o prédio inaugurado em 1900, abrigava o fórum e a cadeia pública da cidade. Gastão relata sua relação com o edifício:

Esta construção, quase centenária, está profundamente ligada à minha história pessoal, sendo que esta ligação apresenta duas vertentes. A primeira é de ordem familiar e por isto, encerra muitas recordações saudosas. (...)

\footnotetext{
2 José Cláudio Gomes em depoimento à autora.

${ }^{3}$ Flávia de Castro Lima em correspondência trocada com a autora via e-mail.
} 
Embora vivendo em São Paulo, por diversas vezes tive a oportunidade de passar minhas férias escolares nesta cidade, em casa de amigos, localizada em frente a este edifício, que já, à época, me encantava profundamente, sabendo-o ligado à história de vida de meu pai.

A segunda vertente é de ordem acadêmica e profissional, nascida de meu interesse em investigar as origens deste edifício, fruto de projeto muito interessante e original. Atribui-se a Euclides da Cunha a sua autoria, entretanto, na realidade, Euclides esteve ligado à sua construção, sendo o projeto arquitetônico de autoria do arquiteto franco-argentino Victor Dubugras, profissional que viveu em São Paulo e que deixou importantíssimas marcas na arquitetura paulista nos fins do século passado e inícios deste século. Entendo que é uma honra para esta cidade ter este edifício ligado a estes dois técnicos - Victor Dubugras e Euclides da Cunha. ${ }^{4}$

De origem francesa e formação argentina, Dubugras apresentou experimentações do Art Nouveau em projetos posteriores a 1900, segundo Segawa(1998), fazendo uso do concreto armado e realizando obras com desenvoltura modernista. Radicado no Brasil desde 1890, já acusava em seus edifícios o respeito à natureza do material, aplicando a exemplo disso, sobre a madeira, nada além de "uma camada protetora de verniz transparente". ${ }^{5}$ Teria ainda segundo Yves Bruand, sido o responsável pela introdução da obra de Frank Lloyd Wright entre os alunos da Escola Politécnica.

Vê-se que a atenção despertada por Dubugras na infância terá reverberações em sua vida adulta.

Luiz Gastão cresceu em meio a um ambiente familiar muito ligado às artes e literatura. $\mathrm{Na}$ casa da família Castro Lima aconteciam frequentemente encontros literários promovidos pela mãe, Dona Iracema,

\footnotetext{
${ }^{4}$ Trecho de discurso de agradecimento feito na Câmara Municipal de São Carlos por ocasião da homenagem recebida como Profissional do Ano. 1995.

5 Toledo, Augusto de. 1905. "Villa Flávio Uchoa". Revista Polytechnica, São Paulo, (2):75:7, jan. apud SEGAWA (1998) pg 33,34.
} 


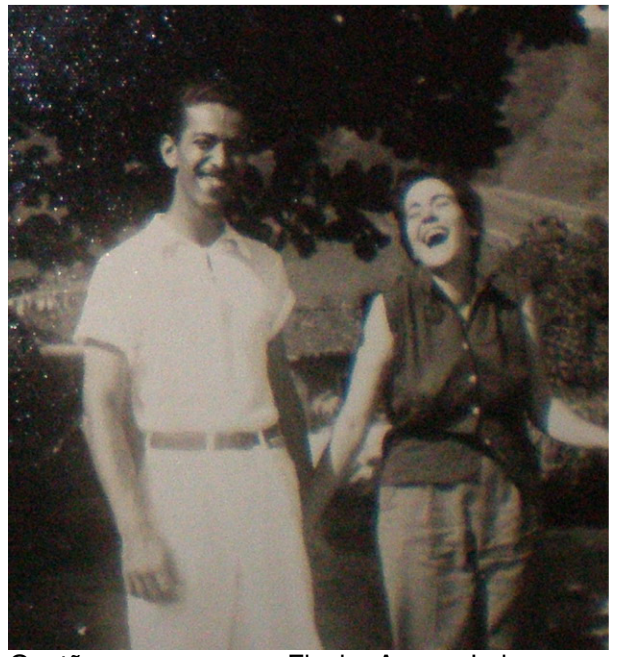

Gastão e sua esposa, Flavia. Acervo Luiz Gastão de Castro Lima. LIEP. UFSCAR segundo relatos, pessoa dotada de grande cultura. Seus pais eram muito bem relacionados com a elite intelectual da época, tanto em São Paulo como em São Carlos, o que levou Luiz Gastão desde cedo a se interessar pelas artes e pela música.

Em São Carlos, faziam parte deste grupo de intelectuais o historiador Luís Saia e o fotógrafo Herman Graeser, mais conhecido como Germano. Saia era sãocarlense e Graeser havia se transferido com a família para a cidade em 1908. Ainda nos primeiros anos como estudante de arquitetura, Gastão teria oportunidade de trabalhar com Graeser e Saia, este último, recémformado pela Escola Politécnica. Juntos colaboraram na documentação do patrimônio histórico empreendida pela primeira leva de alunos da Faculdade de Arquitetura e Urbanismo da USP, reunidos em torno do grêmio estudantil.

Em São Paulo, após algum tempo morando em Santo Amaro, a família Castro Lima se transfere para um conjunto residencial na Rua Berta, em Vila Mariana. Projeto de Gregori Warchavchik, a vila de casas marcaria definitivamente a memória do arquiteto não só pela expressão de sua arquitetura, mas pela relação de vizinhança. Gastão mencionaria anos mais tarde que sonhava frequentemente com o lugar. ${ }^{6}$

Gastão era muito criança (talvez 2 ou 3 anos) quando a família se mudou para São Paulo.

Gastão morou, em criança e até quase se casar, na Vila Mariana, em uma rua estreita (Da. Berta). Tinha, de um lado da rua, casas geminadas projetadas pelo Warchavchik. Era um sobrado, bem 'lembrável' mesmo, com um belo projeto e uma feição muito simpática. Laços

\footnotetext{
${ }^{6} \mathrm{O}$ arquiteto demonstra com expressão bucólica, a presença constante dessa casa em seus sonhos, durante a aula-depoimento dada na EESC-USP. Ver LIMA s/d (data provável 1997) Aula gravada em vídeo-tape; acervo CEDOC-USP
} 


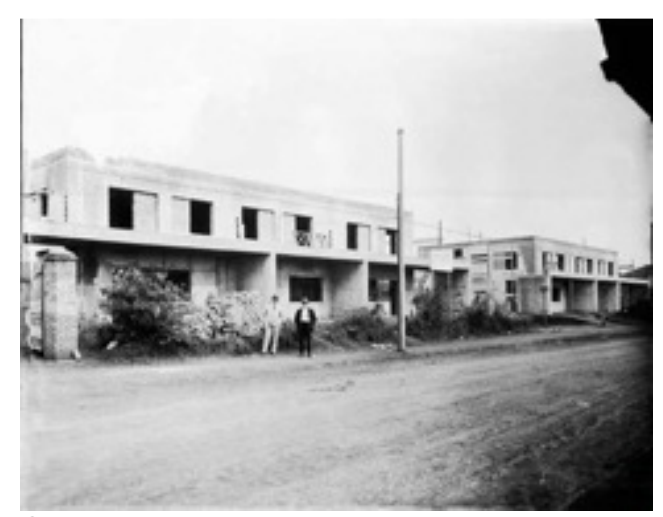

Casas da Rua Berta em 1930.

Fonte: acima: BONDUKI, Nabil: Origens da habitação social no Brasil. São Paulo: Estação Liberdade: Fapesp, 1998. P. 62.

Abaixo: www.maxwell.lambda.ele.pucrio.br/cgi-bin/ As construções da memória e a Casa Nordschild

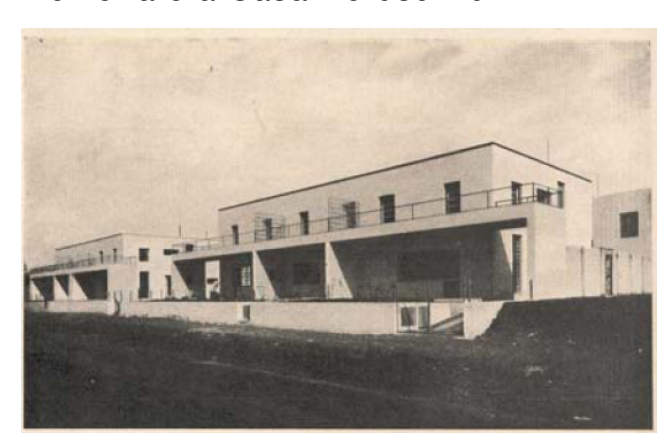

fortes de amizade com os vizinhos fizeram com que ele se lembrasse da casa com saudade. Acho que ele gostava da casa e da localização. Em frente, morava o Segall (onde hoje está o museu) e Gastão foi muito amigo de um dos filhos dele, acho que do Maurício. Em frente, logo à entrada da rua, moravam os Leite Ribeiro; uma das "moças" era concertista e deu aulas de piano ao Gastão a vida toda. Uma vizinha era grande apreciadora de música e o convidava para ouvir discos preciosos na casa dela. Por essa razão, a forte influência sobre ele nas artes todas." 7

Luiz Gastão viveu sua infância durante os anos 30, anos marcados por agitações políticas e culturais. Ingressou na FAU no fim dos anos 40 e se formou no mesmo ano em que São Paulo completava seu quarto centenário e sediava a segunda Bienal de Artes. Lecionou em Brasília durante as tensões da ditadura e teve importantes passagens por diversas instituições de ensino até se aposentar no fim dos anos 90 .

Gastão revela em sua trajetória o perfil de um arquiteto completo, na busca constante da materialização de uma arquitetura honesta e coerente com seu tempo e lugar.

Entre a rotina acadêmica e os projetos no escritório de arquitetura, manteve o olhar constante em seus contemporâneos e uma grande admiração pela obra de Frank Lloyd Wright.

\footnotetext{
${ }^{7}$ Flávia de Castro Lima, em correspondência trocada com a autora via e-mail.
} 


\section{Anos 30: desenho de uma modernidade}

"Paulo Prado escreveu em 1928, seu famoso livro Retrato do Brasil, que tinha como subtítulo Ensaio sobre a tristeza brasileira. A tristeza, o romantismo, a luxúria e o vício da imitação eram apontados como os maiores problemas da nacionalidade. Dois outros livros, O país do carnaval, de Jorge Amado, e Maquiavel e o Brasil, de Otávio de Farias, ambos de 1931, expressavam o clima intelectual da época, marcado pela idéia de crise e incerteza." 8

Em 1928 é publicado Macunaíma de Mário de Andrade e o Manifesto Antropófago de Oswald de Andrade; este último, no primeiro número da recémfundada Revista de Antropofagia, veículo de difusão do movimento antropofágico brasileiro. Em 1925, Gregori Warchavchik veiculava através do Manifesto Modernista, as idéias preconizadas por Le Corbuseir nos artigos publicados em L'Esprit nouveau que foram reunidos posteriormente em Vers une architecture. Em 1929, o mestre franco-suíço já havia estado na América do Sul proferindo palestras em Buenos Aires, São Paulo e Rio de Janeiro. Essa primeira visita teve efeito tardio quando a historiografia deu luz ao caso, mas já em 1929 convidara Warchavchik a representar a América do Sul como um dos delegados do CIAM. Em meados da década Corbusier vem pela segunda vez ao país, no momento em que se esboçavam os traços do primeiro monumento à modernidade brasileira: o Ministério da Educação e Saúde (MES).

\footnotetext{
${ }^{8}$ Brasil em síntese. Site do Instituto Brasileiro de Geografia e Estatística. (www.ibge.gov.br/brasil_em_sintese)
} 


\section{As mudanças na ENBA}

Os anos trinta foram anos marcados por revoluções. Várias publicações conferiam diversos diagnósticos aos males brasileiros. Havia um descontentamento geral, uma necessidade de reinterpretar o passado para compreensão da realidade do país. Uma vontade de identificação e identidade exprimia a consciência social da época. "No meio estudantil notava-se uma grande intranqüilidade. Era uma juventude mais politizada, que não estava mais aceitando a situação vigente." 9

Apesar da repercussão da Semana de Arte Moderna de 1922, até o início da década de 30 a arquitetura brasileira repetia a cópia dos estilos que imperavam na época, à exceção das ações singulares de Warchavchik e Flávio de Carvalho que sopravam ares de modernidade.

O estopim da luta moderna coincide com a chegada

XXXVIII

EXPOSICAAO GERAL

DE BELLAS ARTES

1931
Capa do catálogo do Salão Revolucionário de 1931. ENBA de Getúlio Vargas ao poder. Frente às forças que vinham de Minas e do Sul, Getúlio lidera em 1930 a Revolução que mudaria o país socialmente e politicamente. A vanguarda artística que antes se via no papel de oposição, passa a ocupar a partir de Vargas a elite dirigente de um estado modernizador. Esses efeitos começam a ser sentidos com a criação do Ministério da Educação e com a nomeação de Lúcio Costa para a direção da Escola Nacional de Belas Artes (ENBA). Ao assumir a direção da Escola em dezembro de 1930, Costa inicia uma reforma no ensino, até então baseado no modelo Beaux Arts.

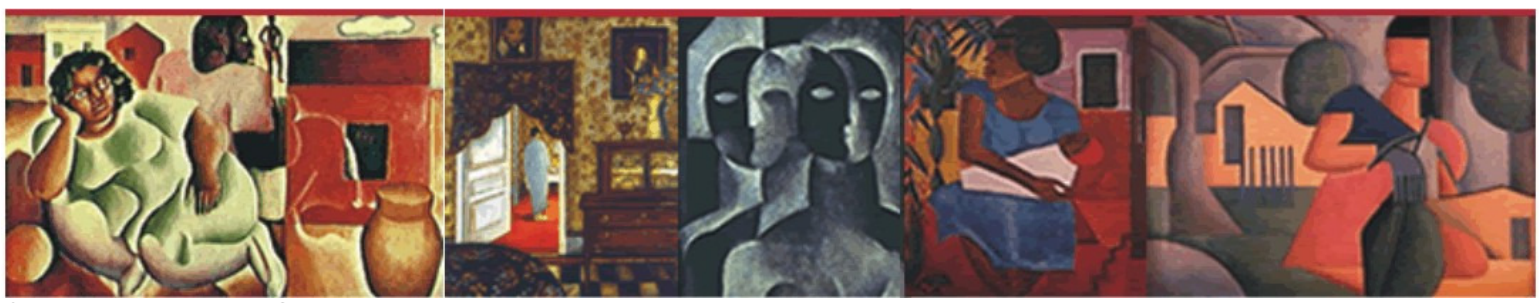

Obras expostas no Salão de 1931.

־ Abelardo de Souza. A ENBA, antes e depois de 1930. In XAVIER, Alberto. Depoimento de uma Geração. São Paulo, Cosac \& Naify, 2003. 

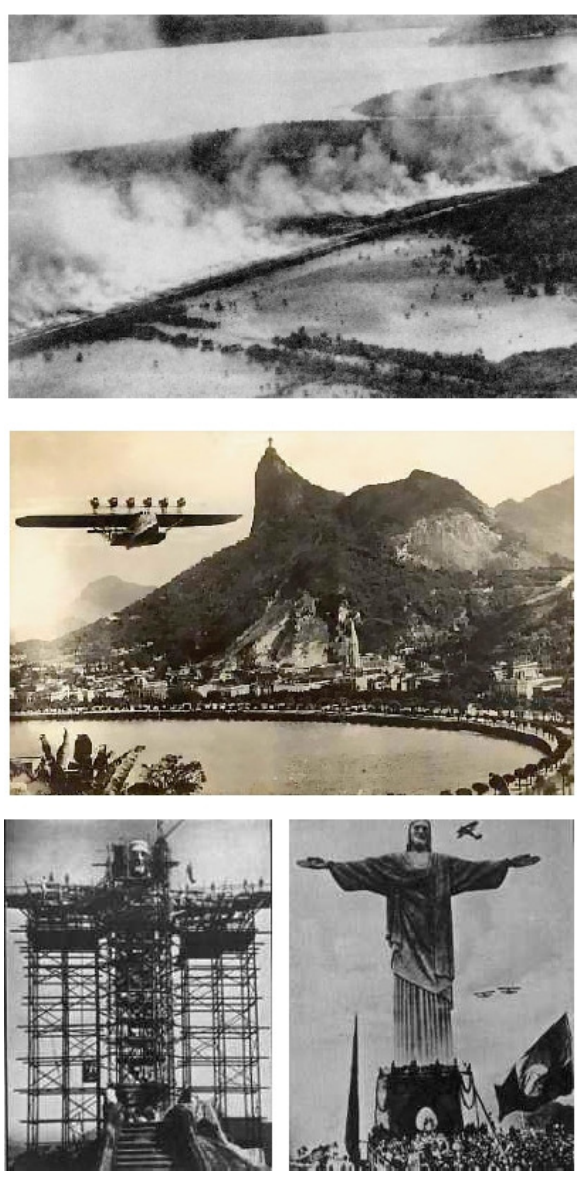

Acima, queima de café na baixada santista, no meio, o hidro-avião DO-X 1929 (maior avião do mundo na época) durante a passagem pelo Rio, no histórico vôo experimental alemão por 45.000 quilômetros pela África e Américas, ao fundo, vê-se a imagem do Cristo ainda com andaimes. Por último, imagens durante a execução da estátua do Cristo e o momento de sua inauguração.
Paralelamente às ações na ENBA, à frente de uma comissão formada por Anita Malfatti, Manuel Bandeira, Celso Antônio e Cândido Portinari, Lúcio Costa promove a XXXVIII Exposição Geral de Belas Artes, que ficou conhecida como Salão Revolucionário de 1931. As medidas de Costa frente à Escola e ao Salão incitam José Mariano Filho. Este, por sua vez, lidera uma campanha contra Costa que resulta na saída do arquiteto da Escola. Poucos dias após a abertura do Salão, dá-se início à greve dos estudantes em protesto à demissão sumária do diretor.

\section{Frank Lloyd Wright no Brasil}

Em 1931, além da histórica reviravolta na ENBA, outros assuntos mereciam destaque nos jornais brasileiros. O governo determinava a queima de milhares de sacas de café numa tentativa de elevar o preço do produto no mercado internacional; Sem dinheiro para honrar os compromissos externos, o Brasil decretava sua primeira moratória; O ensino da língua inglesa tornava-se obrigatório, quebrando o predomínio do francês nas escolas secundárias, enquanto mais de $60 \%$ dos brasileiros continuavam analfabetos; O dirigível Graf Zeppelin aportava no Rio de Janeiro e no alto do Corcovado era inaugurada a estátua do Cristo Redentor, projeto do arquiteto francês Paul Landowski; Em 12 de outubro, de uma estação radiotelegráfica em Gênova, partiram ondas eletromagnéticas que iluminaram a estátua do Cristo do outro lado do oceano.

Os acontecimentos na ENBA coincidem com 0 julgamento do Concurso para o Farol de Colombo, ocasião em que Frank Lloyd Wright, como membro do júri, vem ao Brasil pela primeira vez. O momento era 
tenso em decorrência à greve dos estudantes em apoio a Lúcio Costa. ${ }^{10}$

Se no Brasil reinava um quadro de intensos tumultos, na vida de Frank Lloyd Wright o cenário não era muito diferente. Fujioka (2003) lembra que Wright vinha de um longo período marcado por crises pessoais, escândalos públicos, ameaça de prisão e vários processos judiciais, o que acarretou perdas significativas de projetos e clientes. Além disso, após a quebra da bolsa de Nova York em 1929, poucos projetos foram realizados, alguns cancelados e nenhum construído. Até sua vinda ao Brasil em 1931, Wright se limitava a palestras e publicações. Dentre elas, as mais importantes foram: Princeton Lectures (Princeton University, 1930), Art Institute of Chicago (1930) e New School talks (New school for Social Research, 1931). As publicações "Disappearing City" e "An autobiography" só aconteceriam em 1932.

As palestras em Princeton também foram publicadas (Modern Architecture: being the Kahn Lectures for 1930, 1930) e antecedem as palestras na ENBA ao mesmo tempo em que estas refletem as idéias proferidas em Princeton um ano antes.

Em apoio a Lúcio Costa, Wright defende a reforma no ensino de arquitetura e introduz pela primeira vez entre os brasileiros, o conceito de arquitetura orgânica. Profere palestras também no IAB e visita a casa da família Nordshlid na Rua Toneleros, projeto de Warchavchik.

A imprensa carioca noticiava diariamente os acontecimentos em torno à greve estudantil, ao mesmo tempo em que destacava a visita do arquiteto norte-

\footnotetext{
${ }^{10}$ Para maiores detalhes sobre a vinda de Frank Lloyd Wright ao Brasil, o concurso para o Farol de Colombo e a greve na ENBA, ver IRIGOYEN DE TOUCEDA, Adriana M. Frank Lloyd Wright e o Brasil. Dissertação de Mestrado. EESC-USP, São Carlos, 2000 e o livro também de sua autoria: "Wright e Artigas: duas viagens".
} 
americano e a inauguração da primeira casa modernista no Rio. A casa Nordshild exibia não só uma arquitetura "estranha" aos hábitos brasileiros, mas a idéia de obra de arte total presente inclusive no mobiliário da Laubish \& Hirth e nas telas de Leo Putz.

Apesar do furor na mídia, aos ventos desse tumulto, as palestras de Wright parecem ter tomado um sentido diverso da difusão dos conceitos de uma arquitetura orgânica que parecia ser seu objetivo principal e sobressaído mais como um endosso à atitude estudantil em defesa às mudanças iniciadas por Lúcio Costa.

Os anos seguintes seriam ainda marcados por instabilidades, a exemplo disso, a eclosão da Revolução Constitucionalista de 1932, visando à derrubada do governo provisório de Getúlio Vargas e os vários acontecimentos no cenário internacional que culminaram com a invasão de Hitler à Polônia e com o início da Segunda Guerra Mundial em 1939.

\section{Anos 40: a revisão crítica do projeto moderno}

São Paulo chega a 1940 com mais de um milhão de habitantes, mas apesar das transformações da década anterior, a capital paulista ainda apresentava ares de uma cidade provinciana.

É com o decorrer da década que a cidade virá a se estabelecer definitivamente como um dos pólos industriais mais importantes do país e intensificar sua inspiração no modelo de vida norte-americano, através de um processo de "americanização" que desde os anos 20 vinha tendo o cinema com um dos principais difusores do então chamado "american way of life".

Mas é a partir das ações de uma política de boa vizinhança alinhavada pelo interesse dos Estados Unidos em conquistar aliados na Segunda Guerra que essa relação se torna mais visível e acaba por favorecer 
investimentos e divulgar a produção arquitetônica nacional.

O Brasil já havia mostrado em meados dos anos 30 a qualidade de sua arquitetura através do emblemático Ministério da Educação e Saúde e posteriormente marcado presença com o pavilhão do Brasil na Feira Mundial de Nova York em 1938. Segundo Segawa(1998), esses fatos teriam despertado o interesse americano em organizar a exposição Brazil Builds que teria lugar cinco anos mais tarde e percorreria o mundo, resgatando imagens esquecidas ou mesmo desconhecidas do próprio brasileiro.

Em 1942, a declaração de guerra aos países do Eixo e a união às forças aliadas levaram o Brasil a um estreitamento de relações ainda maior com os Estados Unidos.

Com o fim da Guerra em 1945, o mundo se vê na posição de rever não apenas os aspectos construtivos de seus edifícios, mas também os valores humanos da arquitetura. O movimento moderno passa por uma intensa revisão crítica. É nesse momento que uma nova geração começa a participar das reuniões do CIAM, questionando a hegemonia disputada internamente pelos grupos francês e alemão. Legitimadas por um comitê formado por Walter Gropius, Le Corbusier, Sigfried Giedion, José Luis Sert e Cornelius van Eesteren, as discussões sempre em torno de temas centrais, enfraqueciam grupos que trouxessem "temas incompatíveis com seus interesses práticos".

Os conflitos entre a nova geração e o grupo inicial do CIAM, este último ainda cercado de regras e soluções universais, resultariam anos mais tarde na extinção dos Congressos e na formação de um grupo novo que buscava interpretar e elaborar propostas para os problemas da arquitetura e do urbanismo, a partir das experiências colhidas do seu próprio trabalho. Neste grupo, que ficou conhecido como Team $\mathrm{X}$, talvez 
estivessem as bases para o que mais tarde se configurou como brutalismo. ${ }^{11}$

É nesse momento que se observa certa diversificação na produção da arquitetura moderna, não mais centrada apenas na França, Alemanha, Itália ou Holanda, mas também no Japão, nos países escandinavos e nos Estados Unidos, que se beneficiaram da vinda de Gropius, Mies van der Rohe, Breuer e Mendelsohn. SEGAWA (1998)

Para Segawa(1998), essa fase abre espaço para diversas manifestações, dentre elas, a versão "italianizada" da arquitetura wrighthiana propagada na Europa por Bruno Zevi.

Zevi foi o grande difusor e locutor entusiasmado da obra de Frank Lloyd Wright na Itália e foi por meio de suas palavras que esses conceitos chegaram de forma mais expressiva aos brasileiros, principalmente através de Verso un'architettura organica e Storia dell'architettura moderna.

Se os conceitos organicistas expostos por Wright na ocasião de sua vinda em 1931 não foram amplamente compreendidos pelos brasileiros na época, o efeito pósguerra e a revisão de valores dos anos puramente racionalistas engendraram por um caminho de dissolução de uma hegemonia.

\section{Arquitetura moderna no Brasil: entre o orgânico} e o racional

Desde as primeiras realizações, ainda que fundamentada nos conceitos corbusianos, a arquitetura moderna no Brasil teve existência e linguagem próprias. Segundo Segawa(1998), isso permitiu que se falasse internacionalmente em uma arquitetura brasileira num

${ }^{11}$ BARONE, Ana Cláudia Castilho. Team 10, arquitetura como crítica. São Paulo, Annablume, 
momento em que a arquitetura moderna trazia em si o conceito de um estilo internacional.

À época de inauguração da casa Nordshild, Warchavchik já expressava plena consciência dos conceitos colocados por Corbusier e da necessidade de conciliar o moderno de caráter universal à cultura local.

\begin{abstract}
"Haverá um só estilo moderno, com as suas differenças oriundas do clima e dos costumes. Teremos talvez uma architectura européia, outra sul-americana, outra americana. Finalmente, todas juntas formarão um só estylo mundial, creado pelas mesmas exigências da vida, pelo material idêntico usado para a construção, o concreto, o ferro, o vidro. Aliás, construindo pelas leis da mecânica, da estática, da óptica, da acústica, leis estas todas universaes [...], seremos obrigados a formas todas scientíficas, que por isso serão as mesmas para todos os paízes do mundo. Apezar disto, esta architectura, será a mais regional possivel, porque a sua principal exigência será a de adaptar-se á região, ao clima, aos costumes do povo. $\mathrm{O}$ architecto do futuro não copiará cousa alguma. Procurará inspirar-se no material, do qual usará sempre o mais nobre possível, estudando as condições físicas e os costumes de vida particular dos futuros habitantes. Assim as construções terão carácter original; formar-se-á um estilo novo, próprio do lugar, confortável e de absoluta beleza ${ }^{n}$.
\end{abstract}

Já nos idos dos anos 30, Costa alertava para o perigo do extremismo na interpretação da corrente racionalista, segundo ele, refratária por natureza aos rasgos da pura intuição. Alertava ainda para o emprego fortuito de certas receitas modernistas sem o necessário acompanhamento de uma formulação plástica e de uma "apropriada função orgânica". ${ }^{13}$ Muito antes de Bruno Zevi, Costa já havia dito não haver espaço para qualquer tipo de antagonismo no embate orgânico-racional, colocando essa dualidade como partes de um mesmo corpo, e que por isso mesmo deveriam se equilibrar. ${ }^{14}$

Irigoyen (2000) faz um estudo minucioso sobre o tema organicismo, trabalho este completado pela pesquisa de Fujioka(2003). Acreditamos que não nos

\footnotetext{
2002.

12 Jornal O Globo. O revolucionário das moradias. Pg 02

${ }^{13}$ COSTA, Lúcio. Muita construção, alguma arquitetura e um milagre. in XAVIER, Alberto.

Depoimento de uma geração. $\mathrm{Pg} 78$

${ }^{14}$ Acerca das declarações de Costa no Inquérito Nacional de Arquitetura realizado em 1961.
} 
cabe nessa dissertação retomar todos esses argumentos, mas apenas lembrar alguns conceitos, que julgamos mais relevantes e que revelam uma arquitetura orgânica de raiz romântica marcada pela horizontalidade, pelo espaço fluído, pelo respeito ao material e pelo uso da cor.

Podemos observar que algumas palavras são recorrentes do discurso orgânico. São elas: natureza $\boldsymbol{e}$ unidade. Para Wright, a natureza era a representação máxima de Deus e a unidade, o que deveria haver entre o homem e a natureza.

Dois outros conceitos permeiam seus discursos: plasticidade e continuidade. Esses conceitos remetem à matéria como algo que flui, cresce, não como algo que é postulado, juntado, aderido. Twombly (1979) diz que em Wright, a forma plástica não é composta, mas produzida, desenvolvida por uma espécie de cultivo, germinação. Sullivan usava igualmente o termo "plástico" para ilustrar o tratamento que dava ao edifício na ornamentação, diferenciando-o do adorno aplicado a posteriore, mas como uma continuação do edifício em si. Dessa forma, como em Wright, plasticidade e continuidade se unem em um só conceito e sintetizam o caráter unitário da arquitetura orgânica, esta que deve estabelecer uma harmonia entre suas partes e o meio e unificar os "fatores convocados à sua existência": o terreno, os materiais construtivos, o programa de necessidades individuais, a cultura local, o clima e aliar a tudo isso, as particularidades do arquiteto.TWOMBLY (1979).

Uma estrutura orgânica se estabelece de forma unificada e por assim ser, econômica, expressa e manifesta apenas o que é necessário. Assim se processa na natureza e assim se deve processar na arquitetura, onde forma e função são indissociáveis. 
Irigoyen(2000) destaca que dos seis princípios básicos estabelecidos para a arquitetura orgânica - a simplicidade, o individualismo expressivo, o organicismo do edifício, a harmonia de cores, a fidelidade do material e o caráter da obra - nenhum deles é necessariamente, incompatível com o racionalismo. Argan (1993) entende a oposição assumida pelos conceitos orgânico e racional e os argumentos de alguns teóricos, mas ressalta que a sociedade natural não é menos utópica que a racional, nem a teoria do intuitivo menos abstrata que a do lógico. A fala de Argan é poética e filosófica quando determina uma descendência arquetípica para ambos. Em 1935, Gropius já havia reconhecido a necessidade de satisfação do espírito humano, atribuindo-lhe a mesma importância que a satisfação material dos anos racionalistas: "A racionalização que muitos pensam ser o princípio cardinal da Nova Arquitetura é na verdade, apenas seu agente purificador. A satisfação estética do espírito humano é tão importante quanto a satisfação material." E por fim, Lúcio Costa arremata: "Toda arquitetura digna do nome é a um tempo orgânica e racional, acrescente-se, no caso brasileiro, certa tendência ao idealismo formal, e uma eventual gratuidade, peculiar ao nosso modo de ser."

Ao longo de sua trajetória, Luiz Gastão revela uma conciliação sábia destes conceitos, filtrando suas possibilidades técnicas e plásticas, buscando não apenas referências, mas incorporando princípios.

\section{Inclinação profissional}

No cenário internacional, os debates retomados pelo CIAM após o período de interrupção de atividades motivado pela guerra incluíam o planejamento urbano, a síntese das artes, a reforma da educação, a 
industrialização das construções, os programas sociais e a reforma do Estado. Temas estes tão caros à arquitetura, estiveram sempre presentes na atuação profissional de Luiz Gastão, principalmente em sua vida docente.

Em 1947, pelas mãos de Assis Chateaubriand, é criado o Museu de Arte de São Paulo (MASP). Três anos depois, já com fama internacional, o museu passa por reformas (projeto de Lina Bo Bardi) para abrigar o acervo que ocupou três andares dos Diários Associados. Nesta época, o MASP inicia cursos de desenho, escultura, gravura, desenho industrial, fotografia e cinema, além de História da Arte, da música, entre outros.

Um ano depois da fundação do Museu de Arte de São Paulo, Ciccillo Matarazzo se une a um grupo de intelectuais na criação do Museu de Arte Moderna de São Paulo (MAM-SP) com o objetivo de incentivar o interesse por artistas brasileiros e formar um mercado capaz de consumir essa produção. (ACAYABA, 1994)

Igualmente instalado na sede dos Diários, após adaptação do espaço por Vilanova Artigas, o MAM-SP passa a manter uma cinemateca e promover também cursos sobre História da Arte, gravura, cerâmica, modelagem, desenho e artes gráficas. No mesmo ano de criação do MAM-SP é fundado o MAM-RJ (Museu de Arte Moderna do Rio de Janeiro), segundo Segawa(1998), contribuindo para a formação de uma cultura cosmopolita. Também em 1947, a Faculdade de Arquitetura Mackenzie é reconhecida oficialmente e um ano depois, é criada a Faculdade de Arquitetura e Urbanismo da USP (FAU-USP). Estes cursos promovidos pelo MAM e pelo MASP atraíram muitos estudantes de arquitetura da época e Gastão estava entre eles.

Diz ele que mesmo antes de ter escolhido arquitetura como caminho profissional, certo fascínio pela tecnologia, aliado a uma capacidade enorme de dispersão de habilidades o teria levado desde cedo a 
estabelecer contato com muitas áreas do conhecimento. Viajou nesse período por diversos temas, experimentando desde a ciência pura até a medicina, passando pela música (tocava piano e gaita), pelas artes plásticas, pelo laboratório químico de fundo de quintal, aeromodelismo, eletrônica, e informática.

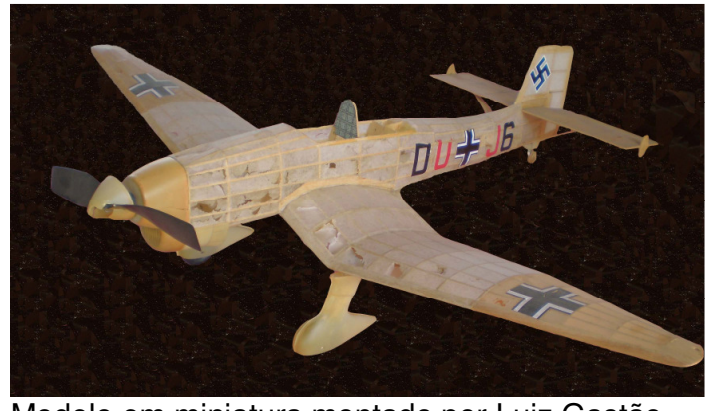

Modelo em miniatura montado por Luiz Gastão em madeira e papel de seda. Propriedade de José Alfeu Rohm. Foto da autora.
"Ele [Gastão] era muito habilidoso, fazia caixilhos em madeira, portas com tela. Sabia trabalhar com máquinas de madeira, fazia um pouco de tudo, metal, hidráulica, elétrica, cuidava da manutenção da casa inteira. Ele era extremamente habilidoso e caprichoso. Não fazia por fazer, fazia bem feito. Tenho um avião que ele mesmo construiu. É um avião entelado com papel de seda, uma coisinha linda demais." 15

Movido por essa dispersão de habilidades, Luiz Gastão ingressa em 1947 no curso de Engenharia Civil da Escola Politécnica, uma vez que na época a Faculdade de Arquitetura e Urbanismo da USP ainda não havia sido criada.

De seus ex-colegas na Poli, destacaram-se nomes como Dante Martineli, que trabalhou em Itaipu e investiu no desenvolvimento de modelos reduzidos em estruturas e o italiano Mário Franco, que calculou mais de dois mil projetos em sociedade com Julio Kassoy desde o início dos anos 50, colaborando com arquitetos como Franz Heep, Plínio Croce, Aflalo e Gasperini, Pedro Paulo de Melo Saraiva, Vilanova Artigas, Jorge Wilheim e Paulo Mendes da Rocha. Martinelli fundaria em 1957 o Laboratório de Estruturas da Escola de Engenharia de

\footnotetext{
${ }^{15}$ José Afeu Rohm em depoimento à autora. Grande amigo de Luiz Gastão, Alfeu Rohm foi durante muitos anos técnico do laboratório do curso de Engenharia de Produção da Universidade Federal de São Carlos, onde ele e Gastão trabalharam juntos.
} 


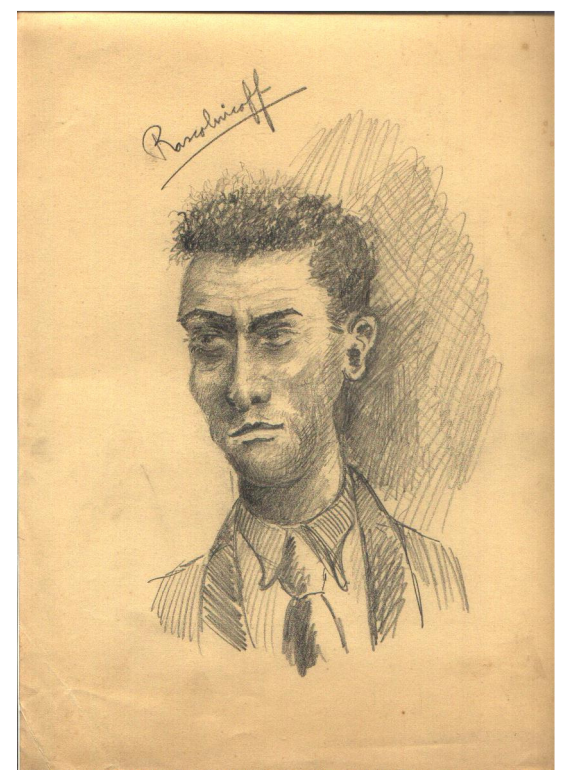

Rusconicolf (célebre personagem de Dostoievsky) Desenho em grafite Luiz Gastão de Castro Lima. Sem data. Acervo do arquiteto.

LIEP.UFSCar

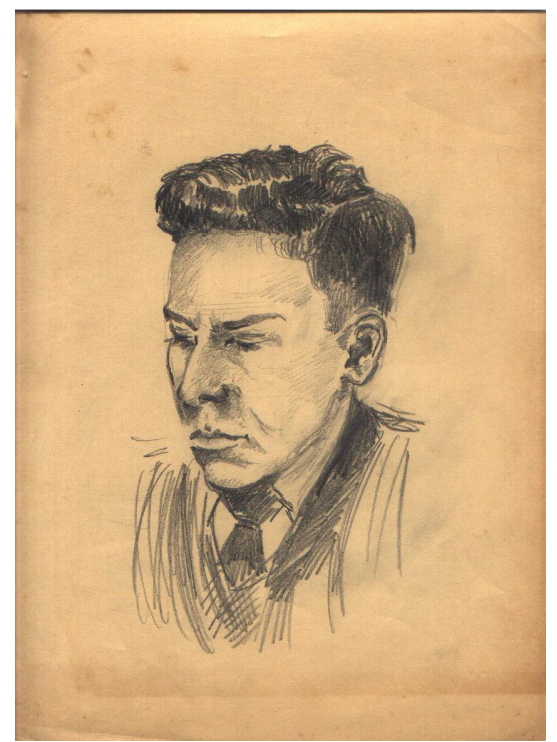

Rosto não identificado. Desenho em grafite Luiz Gastão de Castro Lima. Sem data. Acervo do arquiteto. LIEP.UFSCar
São Carlos, onde ele e Gastão trabalhariam juntos anos mais tarde.

Depois de dois anos na Poli, Luiz Gastão deixa a engenharia para ingressar no recém-criado curso de arquitetura da USP, em 1949. Recorda que sua decisão causou um grande desgosto a seus pais que não veriam realizado o sonho de ter um filho com o "status de engenheiro".

\begin{abstract}
"Quando eu estava no segundo ano da Escola Politécnica e resolvi deixar a Escola pra fazer arquitetura na FAU, a minha família ficou profundamente aborrecida. Foi um problema na família, seríssimo. A minha mãe dizia: "você vai deixar de ser engenheiro para ser arquiteto! "; foi um drama. A minha família ficou profundamente magoada com a minha atitude de ter deixado a Escola Politécnica. Eu deixei porque não era uma escola que me agradasse na ocasião. Talvez se não tivessem criado a faculdade de arquitetura, eu tivesse continuado na Poli, já estava lá, mas achei que a FAU seria um fórum mais adequado."16
\end{abstract}

Suas aptidões artísticas nunca 0 afastaram totalmente das questões técnicas, ao contrário, Gastão sempre acreditou e defendeu a união entre arte e técnica, perseguiu de forma incansável os meios tecnológicos que dariam suporte ao projeto de arquitetura e fez os cálculos estruturais da grande maioria de seus projetos. 


\section{Os primeiros anos da FAU-USP}

Dentre as muitas histórias sobre a criação da FAU, uma em especial ilustra a força de um movimento estudantil liderado por José Silvestre Viana Igreja com o endosso e incentivo de Anhaia Melo. Em depoimento à Rádio USP, em programa que foi ao ar em 2005, José Silvestre conta parte dessa história. ${ }^{17}$

Em 1948, Viana Igreja, então estudante, foi procurado por Luís Inácio de Anhaia Melo que sabendo ser ele, filho do deputado estadual Silvestre Ferraz Igreja, pediu que intercedesse junto ao pai na Assembléia Legislativa a fim de viabilizar a discussão e aprovação do projeto ainda naquele ano, sob pena de perder a validade. O processo tratava da doação à Universidade de São Paulo, do prédio da Rua Maranhão que pertencia à família Penteado.

Incentivado por Anhaia Melo, José Silvestre convocou os alunos inclinados a prestar o exame de habilitação para o curso da Politécnica por meio de um anúncio no Jornal Estado de São Paulo. Convidou-os a se dirigirem ao curso de arquitetura em vias de ser criado na USP. Com uma lista de cerca de 50 nomes, conseguiram apressar o processo e a FAU foi criada em 14 de agosto de 1948.

Luiz Gastão se transfere no ano seguinte, provavelmente influenciado pela ação de José Silvestre e pela repercussão que a FAU teve desde sua fundação. Além disso, uma estreita ligação com pessoas ligadas à

Casa de praia da família Castro Lima. São Sebastião. Aquarela. Luiz Gastão de Castro Lima. Acervo da família. arte $\mathrm{e}$ à cultura o teria influenciado muito nesse momento.

\footnotetext{
${ }^{16}$ Luiz Gastão de Castro Lima. Ver LIMA, Luiz Gastão de Castro. Aula Prof. Gastão e Prof. Caron. EESC-USP. Aula gravada em vídeo-tape. CEDOC. EESC-USP. s/d (data provável:1997)

17 "Conheça a USP". Arquivo em media player, acessível em: http://www.radio.usp.br/programa.php?id=5\&edicao=050603
} 


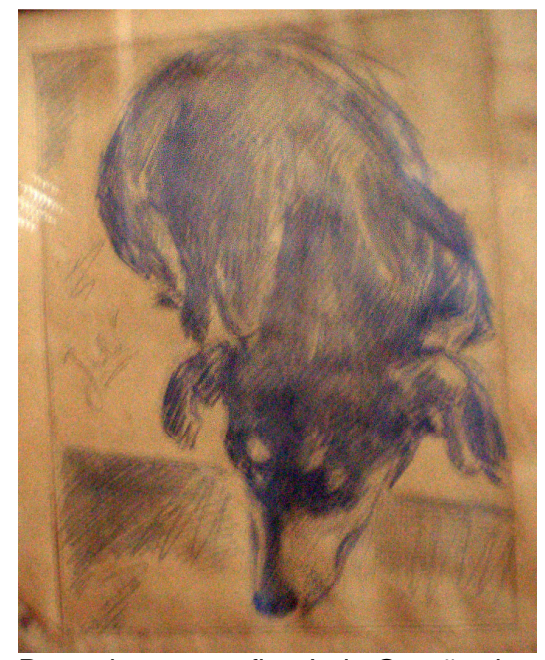

Desenho em grafite. Luiz Gastão de Castro Lima. Acervo da família
Eu tinha uma ligação no circuito de artes, e isso me ajudou muito na minha formação. Eu fui muito amigo do Oswald de Andrade, do filho dele mais velho que era pintor, o Oswald de Andrade Filho, e do [Luis] Saia. ${ }^{18}$

Flávia de Castro Lima se lembra da relação de Gastão com Oswald de Andrade Filho:

(...) um belo dia, ele me levou até à rua Martiniano de Carvalho e eu também fiquei íntima daquele pessoal descolado, maravilhoso, alegres, descompromissados, casa cheia de intelectuais, artistas, um entra-e-sai sem fim. Foi ótimo tempo. ${ }^{19}$

Nesses primeiros anos de funcionamento, a FAU era ainda muito dependente do corpo docente da Politécnica e tinha uma estrutura curricular apoiada na técnica e na lógica do curso de engenheiro-arquiteto da Poli. Além da estreita ligação com a escola de engenharia por meio do quadro docente, dividia com esta suas instalações. Em depoimento organizado pelo IABSP em 1979, Gastão relata:

"(...) a Poli era uma escola muito formal, muito acadêmica desde a maneira de ser, tinha que ir de gravata, coisas desse tipo.

Este é um trecho da história que não foi contado ainda: a Fau era, portanto, muito influenciada pelo curso de engenheiros-arquitetos que a Escola Politécnica matinha, no qual se formou Artigas."

Devido ao corpo docente, o curso da FAU herdara o formato e parte da estruturação da Poli e cambiava entre a engenharia e a belas artes. No entanto, Gastão se lembra que apesar dessa estruturação acadêmica, já

\footnotetext{
${ }^{18}$ Luiz Gastão de Castro Lima. Ver LIMA, Luiz Gastão de Castro. Aula Prof. Gastão e Prof. Caron. EESC-USP. Aula gravada em vídeo-tape. CEDOC. EESC-USP. s/d (data provável:1997)

${ }^{19}$ Flávia de Castro Lima em e-mail à autora.
} 
Desenho em grafite. Luiz Gastão de Castro Lima. 1946. Rio-Passeio Público. Portão da Estátua de Mestre Valentim. Acervo do arquiteto. LIEP. UFSCar havia na época dois jovens professores assistentes que davam uma contribuição renovadora ao curso. Gastão se referia a Vilanova Artigas e Zenon Lotufo, que embora tivessem formação politécnica, permitiram certa abertura e liberdade nas áreas de arquitetura.

Gastão fez parte da segunda turma da FAU, ao lado de Joaquim Guedes, Ariaki Kato, Ginez Velanga, Toshio Tone, Roberto Soares de Camargo, José de Ribamar e Silva, Léo Quanji Nishikawa, dentre outros.

(...) dos estudantes iniciais da FAU-USP, o Gastão foi uns dos que primeiro compreendeu que a FAU, no seu início, era ainda uma descendência da Politécnica. Toda parte técnica dos professores de cálculo, geometria, física vinham da Politécnica. Eram muitos competentes e capacitados, eram os melhores professores do Brasil. Mas também tínhamos como professores os melhores arquitetos do Brasil: Rino Levi, Artigas, Plínio Croce, Jacob Rutchi, o que tinha de melhor estava aqui lecionando. $^{20}$

Alguns destes estariam entre os primeiros arquitetos que se deixaram influenciar pelas idéias de Frank Lloyd Wright.

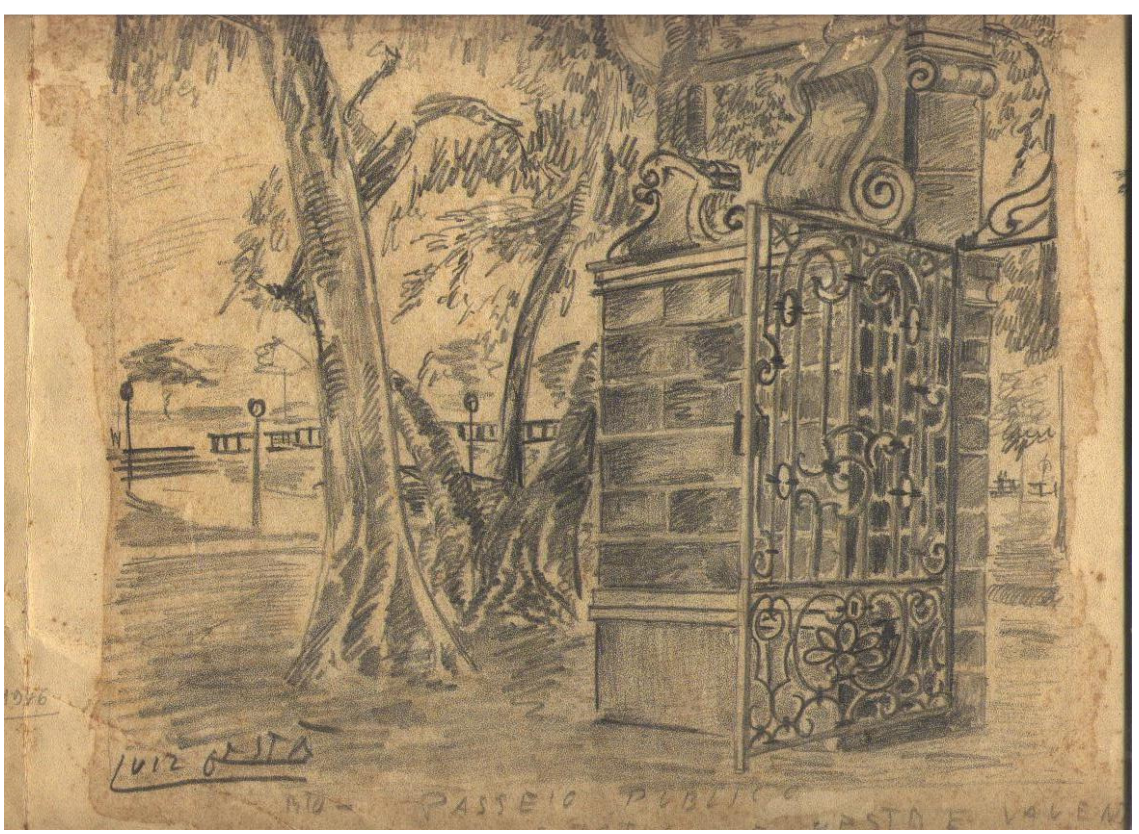

${ }^{20}$ Araquém Martinho em depoimento à autora em 2 de maio de 2008 


\section{O Folclore e as origens remotas do AUH}
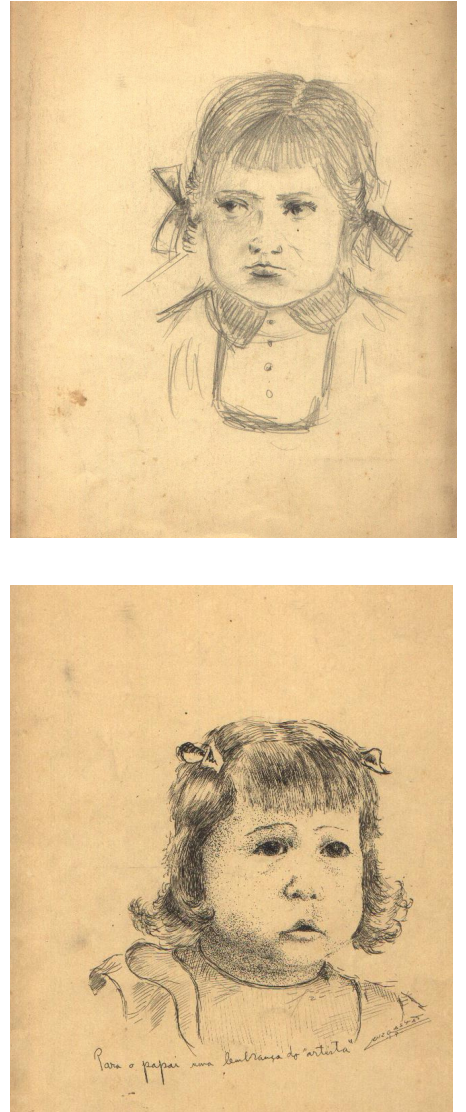

Irmãs de Luiz Gastão de Castro Lima. Desenho em grafite Luiz Gastão de Castro Lima. Sem data.

Dedicatória: " para o papai, uma lembrança do artista Luiz Gastão."

Acervo do arquiteto. LIEP.UFSCar
Quando retiramos a tampa da pia para escorrer a água ali acumulada, começa a aparecer na superfície um movimento circular que vai aumentando até transformar-se num turbilhão, ruidoso quando as últimas quantidades de água, caindo em queda livre, ficam sujeitas a duas forças: a da gravidade, vertical e da rotação da terra, horizontal, à qual está sujeito o tubo. As partículas pioneiras entram num redemoinho cada vez mais intenso, alimentado pela aceleração da gravidade e arrastam as partículas que estão lá em cima.

Gustavo Neves da Rocha Filho

Desde o início da FAU, a necessidade que tinham os alunos em enfrentar as questões colocadas no curso, os levou a um trabalho intenso de pesquisa e documentação. Podemos citar dentre estes trabalhos, a vasta documentação feita pela primeira leva de alunos da Faculdade de Arquitetura e Urbanismo da USP que se uniram em torno de um grupo de pesquisa, o primeiro no âmbito acadêmico e um dos primeiros interessados na documentação da produção arquitetônica nacional.

Vinculado ao grêmio estudantil, o grupo deixou um legado de inúmeras fotografias e desenhos. Luiz Gastão teve grande participação nesse processo.

"Como a minha turma e mais duas anteriores foram praticamente os primeiros grupos formados na FAUUSP, que começou a funcionar em 1949, o nosso grupo teve um papel mais ou menos importante dentro do que foi a faculdade e dentro do que a faculdade se tornou posteriormente. ${ }^{21}$

\footnotetext{
${ }^{21}$ LIMA, Luiz Gastão de Castro (1979). Gastão menciona sua turma como sendo a terceira, e o início da FAU como sendo em 1949. Certamente há um equívoco de datas.
} 


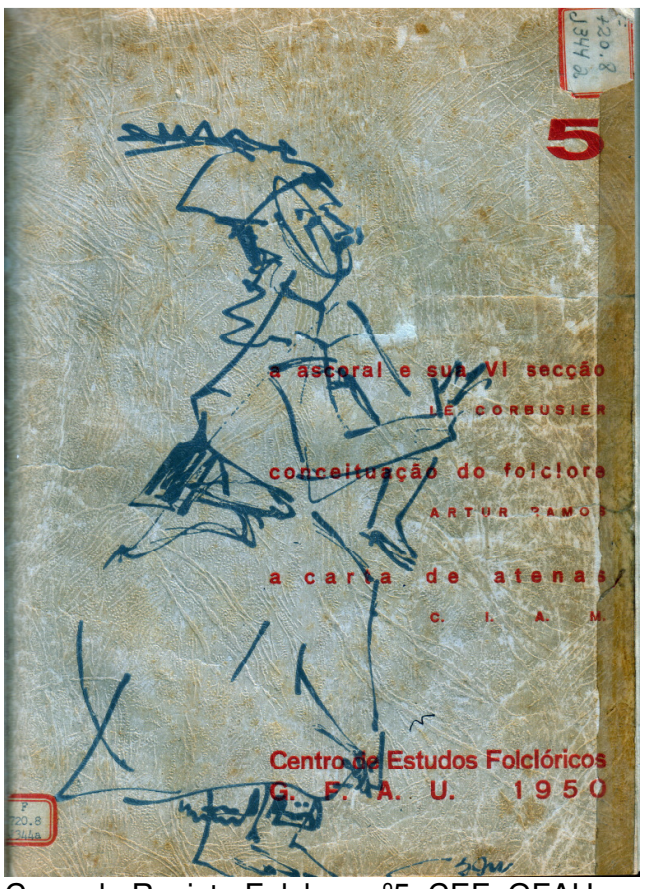

Capa da Revista Folclore n־5. CEF. GFAU. 1950.
Segundo Gustavo Neves da Rocha Filho, a princípio a idéia de se constituir uma agremiação junto ao corpo discente encontrou resistência, pois alguns alunos ainda queriam se filiar ao Grêmio Politécnico. Como esta era a opinião da minoria, acabou não prevalecendo e preponderou a idéia inicial. Em novembro de 1948 foi criado o GFAU (Grêmio da Faculdade de Arquitetura e Urbanismo da Universidade de São Paulo), que teve Marcílio Martins como primeiro presidente, "eleito entusiasticamente dada sua atitude sonhadora, cheia de planos, apresentado e apoiado efusivamente pelo [Antônio Alves] Carvalho" 22

\begin{abstract}
"Aí alguns alunos entraram em queda livre: o Carvalho, o Marcílio, o [Roberto Pinto] Monteiro, o Plínio [Venanzi]... e outros que entraram no vestibular de 49: o [Luiz] Gastão [de Castro Lima], o [José] Cláudio Gomes e o Toshio Tone. Depois arrastaram outros como o Gustavo, - Flávio Mota, o [João Walter] Toscano, o Nestor [Goulart], o Julinho [Katinsky], o Benedito [Lima de Toledo], só para mencionar os que mais tarde viriam a ser os professores do AUH." ${ }^{23}$
\end{abstract}

Neves da Rocha Filho se referia ao primeiro time de alunos disposto a encarar o pioneirismo que se esboçava e que viria direcionar a formação das turmas seguintes.

"Sob a ação das forças naturais", aquele movimento inicial em espiral levou os alunos a constituir em 2 de maio de 1949, o Centro de Estudos Folclóricos (CEF), o primeiro da Universidade e que mais tarde viria a se chamar Centro de Estudos Brasileiros.

Sob a presidência de Roberto Pinto Monteiro, o CEF tinha como membros Antonio Carvalho, Plínio

\footnotetext{
${ }^{22}$ ROCHA FILHO A origem remota do AUH. Testemunho fornecido pelo Prof. Gustavo Neves da Rocha Filho ao Prof. Lúcio Gomes Machado s/d.

${ }^{23}$ Idem. Ibdem. AUH: Departamento de História da Arquitetura e Estética do Projeto da Faculdade de Arquitetura e Urbanismo da Universidade de São Paulo.
} 
Venanzi, Luiz Gastão de Castro Lima, José Cláudio Gomes e Toshio Tone.

"Lançados em queda livre, cada um destes jovens trazia a sua forçazinha que os desviaria da vertical e que acabaria por produzir aquele turbilhão que envolveu dezenas de estudantes ao longo dos anos seguintes." ${ }^{24}$

O time estava montado. Segundo Gustavo Neves da Rocha Filho, Marcílio Martins era um entusiasta, sonhador, idealista. Roberto Pinto Monteiro era mais pragmático e tratou de organizar algo rentável ao Grêmio, criando uma seção de filatelia após a descoberta do interesse dos politécnicos em colecionar selos. Plínio Venanzi manifestava interesse pela fotografia, algo pouco comum entre os arquitetos da época. Estes, normalmente interessados no aperfeiçoamento gráfico, se detinham muitas vezes, tão somente ao desenho. Venanzi era um ótimo fotógrafo e ainda que trabalhasse com escassos recursos, sonhava em construir um ampliador. O Toshio Tone "não largava seu cigarrinho de palha". Talvez visse no grupo uma forma de encontrar suas raízes interioranas. ${ }^{25}$

José Cláudio Gomes era um filósofo. Segundo Neves da Rocha Filho, havia escolhido a profissão de engenheiro-arquiteto, pois assim resolveria o problema de ganhar dinheiro (como engenheiro) e continuaria a filosofar (como arquiteto). Natural de Batatais, Gomes escolheu São Carlos para morar depois de formado. Ficou na cidade por dois anos enquanto acompanhava as obras de duas residências projetadas por ele em Uberaba, seu primeiro trabalho como arquiteto. Voltaria em 1953 como professor da Escola de Engenharia de São Carlos e mais tarde, a convite de Luiz Gastão de Castro Lima, comporia o quadro docente da Faculdade 
de Arquitetura, Artes e Comunicação da UNESP em Bauru.

Mas quanto a Luiz Gastão, Neves da Rocha Filho afirma desconhecer os motivos que o levaram a se interessar pelos temas folclóricos. Lembra-se que certa vez Gastão trouxe ao grupo um texto de Pierre Ferrié, por ele próprio traduzido.

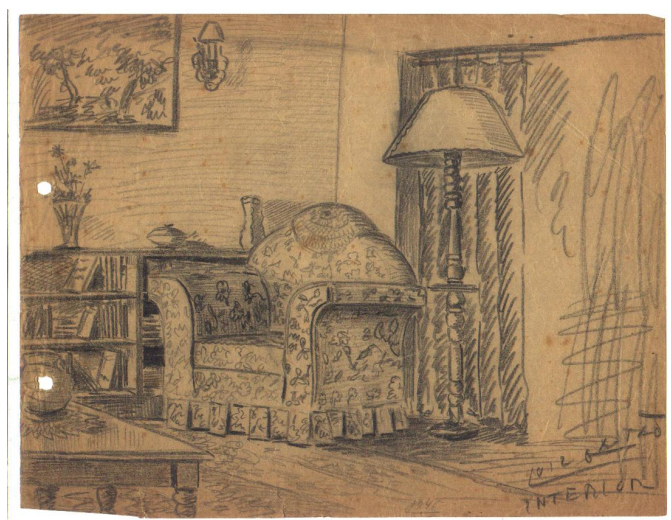

Desenho grafite. Luiz Gastão de Castro Lima, 1946. Acervo do arquiteto. LIEP. UFSCar

\begin{abstract}
"Parece-nos que pesa sobre o folclore um mal entendido. Este termo não é necessariamente sinônimo de estagnação. O mal entendido aparece menos gravemente no domínio das artes ditas gratuitas: a pintura e a música. O mal entendido é mais agressivo nesta arte chamada maior, possivelmente por ela estar fora do jogo - a arquitetura."
\end{abstract}

Estaria o arquiteto desde já consciente da raiz da palavra, do conceito etimológico igualmente consciente em Lina Bo Bardi, do folk-lore. (folk = raça, povo, nação, e lore = instrução, ensinamento, ato de passar o conhecimento adiante) Conceito que revela a cultura de um povo, a sabedoria apreendida através das experiências vividas.

Compartilhando com o mesmo entendimento manifestado por Gastão, Lina caminhou próximo à linha de pensamento de Ferrié. Compreendeu a força motora da cultura popular e desmistificou o conceito de folclore como algo que tende ao imobilismo, à permanência. Não se trata de conservar formas e processos, mas avaliar possibilidades e buscar novas formas, originais. ${ }^{26}$

Também não há como descartar as influências em Gastão exercida por seu círculo de amizades. O relacionamento com Luis Saia, a quem tanto admirava e a grande amizade com Oswald de Andrade Filho, a quem

\footnotetext{
${ }^{26}$ BARDI, Lina Bo. Tempos de Grossura: O design no impasse. Instituto Lina Bo e P.M.Bardi. 1994
} 
afetuosamente também chamava de Nonê, possivelmente despertaram no arquiteto o interesse pelo Folclore.

São-carlense e amigo da família Castro Lima, Luis Saia havia se formado na Politécnica no mesmo ano em que Luiz Gastão deixou a escola. Já havia chefiado em 1937 uma missão de pesquisas folclóricas ao norte e nordeste brasileiro e colaborado com Mário de Andrade na criação do IPHAN, instituto que na época, Saia já dirigia.

Filho do escritor e poeta modernista Oswald de Andrade, o pintor Oswald de Andrade Filho teve como referências Portinari, Anita Malfatti, Lasar Segall e principalmente Tarsila do Amaral, e teria se dedicado a partir dos anos 60 , ao estudo de formas populares tanto em sua morfologia como em seu conteúdo. Disse ele:

Sou por uma arte brasileira com raízes no povo, no folclore. Essa é para mim a maior e mais rica fonte de inspiração para o artista, o único caminho que pode levar a uma criação autêntica e de expressão própria.

Oswald de Andrade Filho. Dezembro de 1963

Nesse momento, a documentação da cultura popular representava mais que um resgate das raízes, a busca de uma autenticidade do artefato nacional contra a oferta indiscriminada de produtos da cultura de massa estrangeiros.

O caminho para a modernidade no Brasil passou por investidas no resgate da cultura do país. Um intenso debate sobre a questão da nacionalidade e da autonomia nacional alimentou a busca por uma arte moderna que exprimisse a vontade e os costumes populares. É do pai de Nonê, Oswald de Andrade, o texto introdutório de uma discussão com foco na problemática do termo nacionalismo. Manifesto Pau Brasil é publicado quase que simultaneamente ao livro Macunaíma de Mário de 
Andrade, de 1928, onde o escritor resgata tradições e costumes do povo brasileiro e os funde numa cultura única e sem regionalismos.

Além de sua obra publicada, a contribuição de Mário de Andrade para a documentação da cultura popular passa pelas viagens etnográficas que fez principalmente ao norte e nordeste do país a partir de 1927, pela criação da Sociedade de Etnografia e Folclore de São Paulo e pelo projeto do Departamento de Cultura em 1937, através do qual um ano antes enviara a primeira missão de pesquisa folclórica ao nordeste, missão esta que foi chefiada por Luis Saia. Também contando com a colaboração de Saia, Mário de Andrade cria o Serviço do Patrimônio Histórico e Artístico Nacional (SPHAN), através do qual promove restauros no Convento do Embu (documentado pelo GFAU) e na Igrejinha de São Miguel Paulista. Mário de Andrade ainda foi colaborador de Gustavo Capanema e influenciou e se deixou influenciar por muitos de seus contemporâneos, incluindo Manuel Bandeira, Carlos Drummond de Andrade e o folclorista potiguar Luis da Câmara Cascudo, realizador do que se pode considerar hoje a maior obra folclórica do país. ${ }^{27}$

${ }^{27}$ Para maiores detalhes sobre a influência de Mário de Andrade na obra de Luis da Câmara Cascudo, ver MELO, Veríssimo de. A obra folclórica de Cascudo como expressão do movimento modernista no Brasil, col. Mossoroense, ㄲo 643, 1989 e ANDRADE, Mário. Cartas de Mário de Andrade a Luis da Câmara Cascudo. Itatiaia, 2000. Mário de Andrade foi ainda sócio da Sociedade Brasileira de Folclore, a primeira no gênero, fundada por Luis da Câmara Cascudo em 30 de abril de 1941. 
Segundo Neves da Rocha Filho, esse primeiro grupo do Folclore, como foi carinhosamente apelidado o CEF, logo se desinteressou pelo tema propriamente dito e se dedicou às questões mais diretamente ligadas à arquitetura. Nesse momento dava-se início dentro da FAU, a um movimento intenso de documentação e divulgação da arquitetura nacional.

Os alunos reunidos em torno do grupo iniciaram um levantamento métrico arquitetônico nas casas da Aldeia de Carapicuíba, na Capela Jesuítica de São João Batista, na casa do Bandeirante e em várias casas do século XVII da periferia de São Paulo.

Quando os trabalhos já iam bem avançados, o grupo despertou o interesse de Luis Saia. Ao tomar conhecimento de uma terça decorada descoberta pelo CEF na sacristia da capela, Saia enviou Herman Graeser, que na época já era fotógrafo do SPHAN, para acompanhar os alunos na documentação. Saia e Germano (como era conhecido Herman Graeser) haviam sido referências culturais de Luiz Gastão na infância e certamente teria Ihe causado grande satisfação 0 acompanhamento de ambos às investidas do Folclore. Também os acompanhou desda vez, o folclorista piracicabano Alceu Maynard de Araújo.

Nascido em Piracicaba em 1913, Maynard de Araújo publicaria anos mais tarde diversos livros sobre usos e costumes brasileiros, dentre eles, Documentário Folclórico Paulista, Cultura Nacional Brasileira (1973) e os três volumes de Folclore Nacional (1964)

O trabalho dos alunos em torno do CEF se estendeu ao longo de 1949, semanalmente, enfrentando diversas dificuldades, mas rendendo além de um aprendizado inestimável, uma documentação preciosa. No fim do ano, o grupo organizou na FAU uma exposição dos trabalhos desenvolvidos até então. $O$ evento 
coincidiu com a inauguração do prédio da Vila Penteado que acabara de ser restaurado e passara a abrigar as instalações da Faculdade de Arquitetura da USP. A transferência da FAU para a casa da Rua Maranhão representava um significativo afastamento, ainda que num primeiro instante físico, da Escola Politécnica.

Após a exposição os trabalhos se intensificaram e G. Oscar Campiglia também passou a acompanhar o grupo e a colaborar com recursos da reitoria, disponibilizando material fotográfico. $\mathrm{Na}$ ocasião, Campiglia era chefe de seção de arte da Reitoria e costumava registrar através da pintura, paisagens bucólicas de São Paulo.

O grupo havia recebido uma doação de um dos moradores da aldeia de Carapicuíba de cerca de trezentas publicações, entre elas, revistas do SPHAN, incluindo a de número 5 , que trazia o ensaio de Lúcio Costa "A arquitetura dos jesuítas no Brasil", editada em 1941. Gustavo Neves da Rocha Filho, ao descobrir as revistas nas prateleiras do Folclore, que nesta época já ocupava os porões da Vila Penteado, se entusiasmou em documentar os monumentos mencionados por Costa no ensaio.

No ano seguinte, o Centro de Estudos Folclóricos voltou seu olhar para a igreja de Nossa Senhora do Rosário do Embu. Havia uma chácara atrás da igreja, de propriedade da família de Flávio Mota, e segundo Gustavo Neves da Rocha Filho foi nessa ocasião que Mota se envolveu com o grupo e de forma mais estreita com Luiz Gastão.

Mota era monitor do Museu de Arte de São Paulo, inaugurado em 1947. Muito provavelmente influenciado por ele, ainda como aluno do primeiro ano da FAU, Gastão participou do curso de História da Arte ministrado por Pietro Maria Bardi, para trabalhar como monitor no recém-fundado MASP. 
$\mathrm{Na}$ igreja de Nossa Senhora do Rosário, Gustavo Neves da Rocha Filho faz as primeiras experiências fotográficas com filmes coloridos. Entusiasmado com o resultado, inicia um processo de documentação produzindo diapositivos (slides), que foram disponibilizados para os assinantes da Revista Bem Estar, publicada anos mais tarde sob sua direção. A revista que teve curta duração, chegou a publicar um artigo de Luiz Gastão. Lançada em fevereiro de 1958 por Gustavo Neves da Rocha, o periódico teve seis números, sendo que os dois últimos se condensaram em uma única edição, em junho de 1960. Contava na época com trinta e dois "assinantes remidos e colaboradores" contra os quinze iniciais.

O artigo de Gastão saiu na terceira edição, em dezembro de 1958 intitulado "O Equipamento da Habitação - Introdução". No artigo discorre sobre o mobiliário como parte integrante da construção e coloca de forma clara algumas concepções que viriam nortear muitas das escolhas técnicas e construtivas de sua obra.

Segundo nota introdutória, o objetivo do texto seria "dissecar a habitação sob o ponto de vista de seus componentes, (...) de maneira a apresentar todas as tendências da arquitetura contemporânea", apresentação esta que seria "entremeada de desenhos e fotografias elucidativas." O título sugere que haveria uma seqüência de artigos, mas se Gastão os escreveu, não chegou a publicá-los.

Com o passar dos anos, os debates sobre as questões da arquitetura de Frank Lloyd Wright e Le Corbusier se intensificaram na FAU. Algumas publicações caseiras de textos de Corbusier despertaram nos alunos o ensejo de se libertarem definitivamente das influências da Poli. Articulados em torno do CEF, os estudantes descobriram nas palavras da ASCORAL, o ideal do "Folclore": "a retomada do solo do país conduz, 
naturalmente, à organização do inventário do que nele existe". Essa frase, lembrada por Gustavo Neves da Rocha, sintetizaria toda a ação do grupo.

Nos anos seguintes, por ação do Folclore e do GFAU, várias publicações impressas em um mimeógrafo cedido por Anhaia Melo reproduziram publicações do SPHAN, dentre elas, um levantamento da casa do sítio do Padre Ignácio datado de 1945. Os alunos ingressantes no curso eram convocados a montar e vender os encartes. O número de adeptos do Folclore cresceu e o interesse pela arquitetura nacional dentro da Faculdade também. No final de 1950, durante uma viagem a Minas Gerais, documentaram as cidades de Sabará, Mariana, Ouro Preto e as obras de Oscar Niemeyer em Belo Horizonte, desta vez com a participação de Ariaki Kato.

Os cromos produzidos pelo grupo foram oferecidos aos assinantes da revista Bem Estar e adquiridos por diversas instituições de ensino e muitos arquitetos brasileiros e estrangeiros na Argentina, Uruguai, Venezuela, Colômbia, Japão, Peru, Itália, Alemanha e Canadá, promovendo uma intensa divulgação da arquitetura nacional colonial e contemporânea.

As ações destes jovens desbravadores, ávidos estudantes da arquitetura, foi o início de um movimento que resultou no turbilhão mencionado por Gustavo Neves da Rocha Filho e com certeza forneceu elementos para que anos mais tarde surgissem publicações como o livro Igrejas do Brasil de G. Oscar Campiglia e os textos de Luis Saia, estes últimos condensados em 1972 em Morada Paulista. Renderam inclusive material de pesquisa para as obras de Maynard de Araújo.

Os trabalhos iniciados pelo grêmio não pararam por aí. As investidas do primeiro grupo continuaram rendendo matéria básica para publicações futuras. 
A partir de 55 e nos anos seguintes, através do Grêmio da FAU, fizemos uma pesquisa da obra do arquiteto Lúcio Costa, pois dizíamos: se tudo começou lá, vamos começar pelo princípio". ${ }^{28}$

Abraão Sanovicz continua o relato lembrando que com base nesse pensamento, procuraram por Lúcio Costa pessoalmente e a partir de sua indicação iniciaram a análise de algumas de suas obras, descobrindo inúmeros textos e projetos que foram posteriormente cedidos pelo grêmio da FAU ao arquiteto Alberto Xavier.

Esta teria sido mais uma valiosa colaboração do grêmio da FAU, desta vez rendendo matéria prima ao livro "Sobre arquitetura", primeiro trabalho a editar textos completos de Lúcio Costa e principal referência sobre o arquiteto para pesquisadores e historiadores até os dias de hoje.

A partir das ações do CEF, do crescimento do movimento estudantil dentro da FAU e do interesse em torno da documentação histórica, começa a se esboçar o AUH (Departamento de História da Arquitetura e Estética do Projeto) que incorporou no seu corpo docente muitos dos antigos membros do grêmio.

Na década de 1960 o grêmio passa a atuar com força política dentro e fora da Universidade. Participa ativamente do fórum de debates que antecedeu a reforma curricular de 62 , até perder a legalidade com 0 golpe de 64. A exemplo do que aconteceu em todo o país nos anos seguintes, muitos alunos deixaram a agremiação estudantil e partiram para a luta armada.

\footnotetext{
${ }^{28}$ Abraão Sanovicz em depoimento ao IAB. Ver INSTITUTO DOS ARQUITETOS DO BRASIL - São Paulo. Arquitetura e desenvolvimento nacional: depoimentos de arquitetos paulistas. Pini, São Paulo, 1979. pg 57
} 


\section{O concurso de cartazes para a $1^{\text {a }}$ Bienal}

Movidos pela experiência do Museu de Arte Moderna criado em 1948, Ciccilo Matarazzo e sua esposa Yolanda Penteado se mobilizaram em torno da realização de uma Bienal de Artes no Brasil, nos moldes das exposições de Veneza.

Contribuíram para essa fermentação cultural, as exposições de Alexander Calder organizada por Henrique Mindlin em 1948 e a do suíço Max Bill em 1950.

A primeira que aconteceu no Rio de Janeiro e a segunda em São Paulo, teriam segundo Hugo Segawa, influenciado uma nova geração de artistas brasileiros e culminado na Primeira Bienal Internacional de Artes Plásticas de São Paulo que aconteceu no primeiro ano da década de 50. SEGAWA (1998)

A Primeira Bienal envolveu em torno de sua organização além de Luis Saia, diversos nomes importantes e alguns ligados à FAU como Lourival Gomes Machado, Sérgio Milliet, Jacob Ruchti, Miguel Forte e Eduardo Kneese de Mello. A idéia da realização de uma mostra internacional em terras brasileiras logo após a inauguração do Museu de Arte Moderna, gerou euforia entre os estudantes, artistas e intelectuais da época.

Levado pelo agito cultural da ocasião e possivelmente incentivado por Saia, Luiz Gastão participou do concurso de cartazes para a $1^{\text {a }}$ Bienal sob o pseudônimo Macunaíma. Pseudônimo este que traz em si, sinais do seu envolvimento com o Folclore.

Dentre os diversos cartazes recebidos, a Bienal premiou quatro deles. O primeiro prêmio foi atribuído a Antonio Maluf, e em segundo lugar, ficou o trabalho de Darci Penteado. 


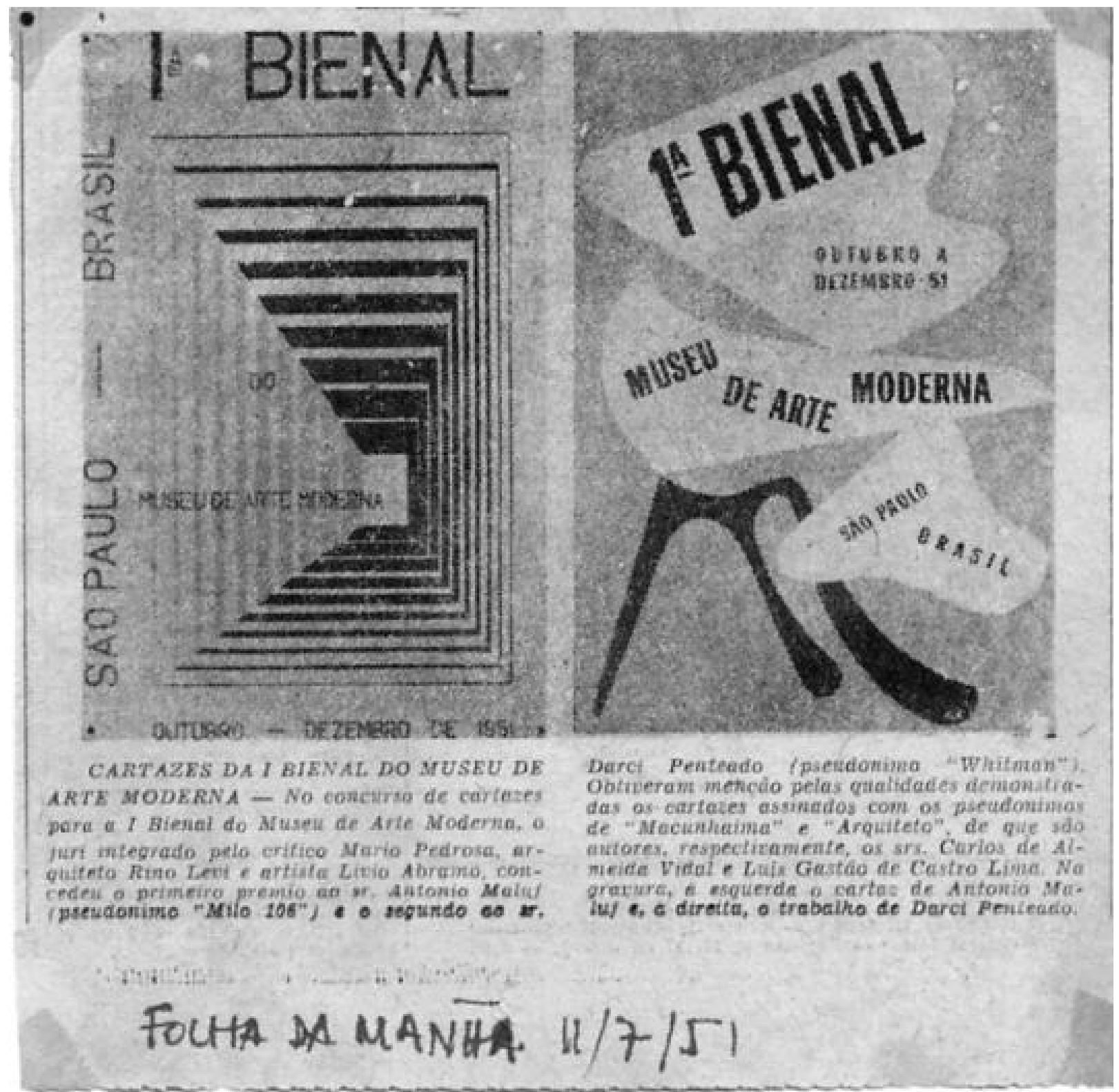

Matéria do Jornal Folha da Manhã, de 11 de julho de 1951. Na foto, os cartazes premiados em primeiro e segundo lugar, onde se vê a atribuição da menção honrosa e o nome de Luiz Gastão. Fonte: Arquivo Histórico Wanda Svevo.Fundação Bienal de São Paulo.

Foram atribuídas duas menções honrosas: a Carlos de Almeida Vidal e a Luiz Gastão de Castro Lima.

O júri do concurso, composto por Lívio Abramo, Mário Pedrosa e Rino Levi justificou a premiação a Luiz Gastão e a Almeida Vidal, atribuindo-lhes o feito de "corresponderem ao espírito moderno exigido pelo concurso", ainda que as qualidades dos cartazes não tivessem alcançado nível técnico satisfatório. 
O Juri de Premiaçáo foi constitujido pelos srs. L.ivio Abramo, delegado do Presidente do Muscu de Arte Mo. derna, Mário Pedrosa. indicado pela Diretoria do Museu, e Rino L.evi, eleito pelos artistas. Reunido nos dias 21, 22 e 23 de junho resolveu conferir o primeiro prèmio ac cartaz apresentado sob pse sdônimo "Milo 106", de autoria do Str. António Maluf, "pelas qualıdarles fundamen. tais... cue o diferenciam dos demais, nă obstante as deficièncias de oriem secundária que apresenta". O segundo prémio foi conferido ao cartaz do sr. Darci Penteado, so' pseudónimo "Whitman" havendo duas mençōes honrosas aos sts. (arbos de Almeida Vidal ("Arquiteto") e L.uis Gastäo de Castro Lima (Macunaima"), "por corresponderem ao espirito moderno exigido pelo concurso, embora suas qualidades de cartaz sejam deficientes".

Página 36 do Catálogo da 1ª Bienal de São Paulo. Fonte: Arquivo Histórico Wanda Svevo. Fundação Bienal de São Paulo.

O arquivo histórico Wanda Svevo da Fundação Bienal de São Paulo tem em seus documentos as reproduções fotográficas de quatro cartazes. Dois deles sem identificação. Dadas às condições da época, não seria viável reproduzir em cromos toda a sorte de cartazes enviados ao julgamento, fato este que nos leva a crer que apenas os que foram premiados chegaram a ser documentados.

Estavam identificados o primeiro e segundo lugar. Restava-nos a façanha de identificar os outros dois. Numa primeira busca não localizamos nenhum trabalho posterior de Almeida Vidal, sendo que nos restaria apenas investigar os trabalhos do próprio Luiz Gastão. Sua esposa, Flávia de Castro Lima, analisando as duas imagens nos declarou prontamente:

"O cartaz com círculos não é do Gastão, decididamente. Se há um do Gastão, é o segundo, com linhas retas e sóbrio, à feição dele (eu chamaria de Cartaz Le Corbusier...)"

Poderíamos sustentar a tese de que o cartaz de formas triangulares é de Luiz Gastão, uma vez que ele 

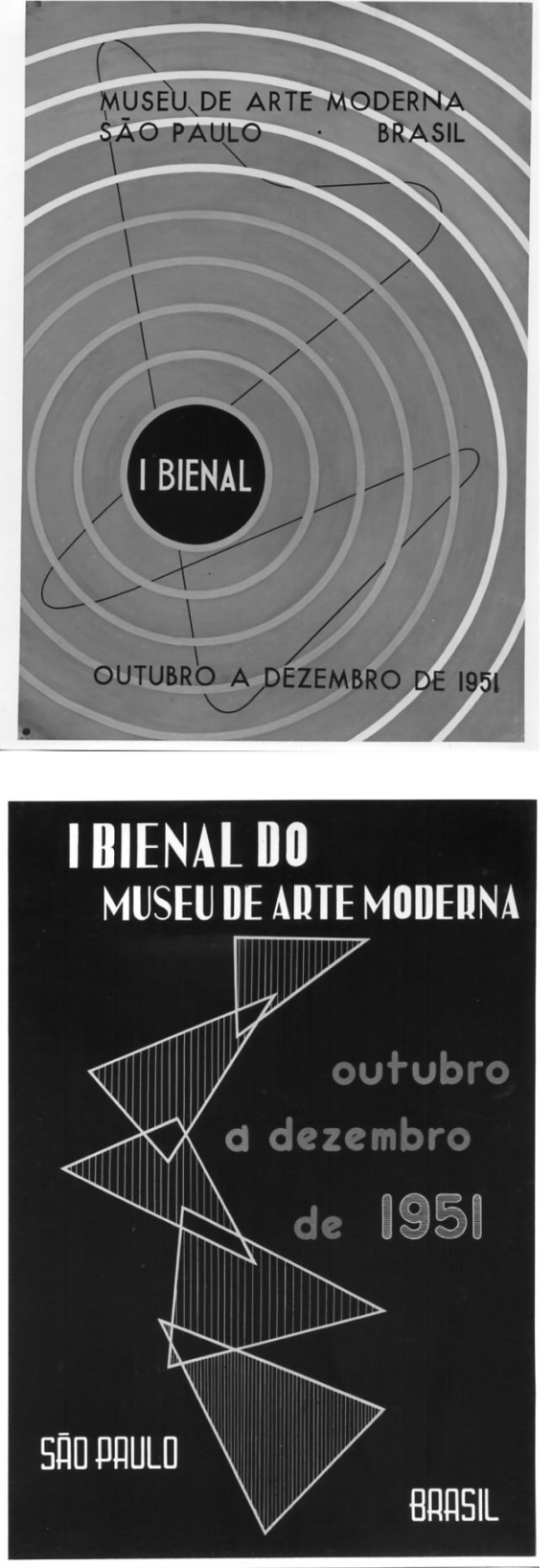

Cartazes possivelmente premiados no concurso de cartazes da $1^{\mathrm{a}}$ Bienal de São Paulo.

Sem identificação.

Fonte: Fundação Bienal, arquivo histórico Wanda Svevo recorrerá à figura geométrica do triângulo outras vezes, inclusive na logomarca da empresa COCIBRA desenvolvida em 1971, justificando a adoção da forma à idéia de estabilidade. ${ }^{29}$

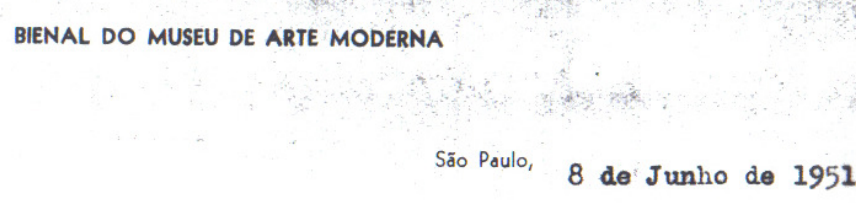

Recebemos 3 cartazes com as assinaturas de MACUMAIMA

Secretaria da I Bienal de ião Paulo

Recibo de entrega dos cartazes para o Concurso da $1^{\text {a }}$ Bienal. Fonte: Arquivo Histórico Wanda Svevo

Já na época do concurso de cartazes, Luiz Gastão desenhava tiras ilustradas para um jornal paulistano como forma de sustentar seus estudos. Essa paixão pelo desenho e por histórias em quadrinhos foi presente em toda sua vida. Em seu depoimento, o produtor de teatro amador Névio Dias, se diverte ao lembrar:

Eu e o Gastão tivemos em comum algo curioso. Nós éramos fãs de histórias em quadrinhos. Ele ficou com uns volumes meus, uma edição em três línguas que tinha o desenho de quadrinhos do Leonardo da Vinci. Eu tinha uma coleção de revistas, das primeiras que lançaram no Brasil: Flash Gordon, Tarzan, que também ficaram com ele. Ele era fã, era aficionado por quadrinhos e nós trocávamos figurinhas, emprestávamos as revistas. Ele nunca as devolveu. ${ }^{30}$

\footnotetext{
${ }^{29}$ Acerca das declarações feitas por Ary Lolato em depoimento à autora. O logotipo da COCIBRA não foi localizado.

${ }^{30}$ Névio Dias em depoimento à autora.
} 
Esse notável interesse do arquiteto pelo desenho que esteve presente em toda sua vida encontrará na docência seu maior ponto de inflexão.

\section{Os wrightianos da FAU}

Desde a década de 50 o ensino de Arquitetura em São Paulo enfocava uma grande discussão de valores éticos e estéticos, tendo como centro vital a Faculdade de Arquitetura e Urbanismo da USP, criada no final da década anterior. A partir desse momento grandes nomes surgiram em São Paulo sob a égide de Vilanova Artigas.

A profissão de arquiteto vinha ganhando respeitabilidade no país desde a regulamentação federal e a criação do Confea (Conselho Federal de Engenharia e Arquitetura) em 1933. Esse processo se intensifica a partir da reestruturação da ENBA e da criação no Rio de Janeiro da Faculdade Nacional de Arquitetura da Universidade do Brasil (1945), da validação dos diplomas da Escola de Arquitetura e Urbanismo de Minas Gerais (1946), do reconhecimento da Faculdade de Arquitetura Mackenzie (1947), da criação da Faculdade de Arquitetura e Urbanismo da USP (1948) e ao longo dos anos 50, do reconhecimento definitivo dos cursos de Porto Alegre, Pernambuco e Salvador.

A atenção que se deu sobre o projeto de Brasília elevou a profissão a níveis ainda mais altos, momento em que muitos engenheiros diplomados buscaram especialização em arquitetura. SEGAWA (1998-pg131) No âmbito da FAU, as discussões giravam em torno da polêmica entre os adeptos de Wright e Corbusier.

Já com uma terceira turma, os alunos da FAU começaram a ter preocupações diferentes: uns começaram a se encantar com as obras de Frank Lloyd Wright, outros Le Corbusier e os professores de projeto 
não viam com bons olhos o interesse de uns poucos pela arquitetura colonial, então "ultrapassada" diziam eles. ${ }^{31}$

Nesta época crescia a divergência no âmbito do discurso arquitetônico dentro e fora da Universidade entre os racionalistas e os organicistas, ou como costumavam se declarar, os "corbusianos" e os "wrightianos". Esses dois "pólos" geraram no seio da discussão moderna, debates interessantes que foram muitas vezes além do aspecto arquitetônico. Entre os declaradamente wrightianos, estava Luiz Gastão de Castro Lima.

O Gastão era wrightiano, só pensava no Frank Lloyd, só falava do Frank Lloyd, mas era um excelente arquiteto. ${ }^{32}$

Dentre os primeiros wrightianos da FAU podemos citar José Cláudio Gomes. Formado um ano antes que Luiz Gastão, teve com o arquiteto estreitas relações pessoais e profissionais.

As turmas seguintes aumentaram o time de simpatizantes da arquitetura wrightiana: Ludovico Martino, Henrique Pait, Eduardo de Almeida, Dácio Ottoni, Arthur Fajardo Netto, entre outros. Mas a existência dos dois grupos não representava uma divisão da FAU entre Wright e Corbusier, haja visto que o grupo wrightiano era pequeno. Gastão dizia que na época da faculdade, era um "verdadeiro crime" ser wrightiano no Brasil.

As discussões, apesar de polêmicas, aconteciam sempre de forma modesta e polida. Algumas ações isoladas acabaram ficando mais conhecidas, como a manifestação simbólica do enterro de Frank Lloyd Wright liderada pelos corbusianos da FAU na ocasião do

\footnotetext{
${ }^{31}$ ROCHA Fo, Gustavo Neves da. "A origem remota do AUH". Texto fornecido ao Prof. Lúcio Gomes Machado. s/d

${ }^{32}$ Declaração de Carlos Lemos, em conversa informal com a autora, na ocasião de abertura da $7^{a}$ Bienal Internacional em São Paulo, em 6 de novembro de 2007.
} 
falecimento do arquiteto em 1959. Mas estas, mais que richas e provocações, resultaram em buscas e pesquisas de ambas as partes.

Éramos organicistas, o Gastão, eu, tínhamos descoberto na faculdade a obra do Frank Lloyd Wright, mas não havia muita polêmica como costumam dizer. $O$ grupo de wrightianos era muito pequeno, éramos uma minoria, meia dúzia de gatos pingados. A fase wrightiana do

Artigas já havia passado. Artigas rumava para o brutalismo. Não tínhamos muita audiência. De fato nem chegou a se constituir uma tendência organicista, era admiração pela obra do Wright apenas. Era a tentativa de se fazer algo mais real.

A arquitetura do Wright tinha também uma ligação com a arquitetura neocolonial de Lúcio Costa, tinha confluências com essa postura mais pé no chão.

(...) Já em 1949, entramos em contato com as obras do Frank Lloyd Wright, alguns livros, revistas e começamos a fazer arquitetura à moda do Wright. ${ }^{33}$

Gastão e Cláudio Gomes nutriram grande amizade que nasceu ainda na graduação e durou por toda vida.

Nós éramos grandes defensores da obra do Wright, eu e o Cláudio Gomes. Nós éramos as macacas de auditório do Wright, os chamados wrightianos. ${ }^{34}$

Não destacamos a possibilidade que Gastão tenha, ainda durante os anos da Politécnica, entrado em contato com as obras de Wright. Esta, desde o início, o sensibilizou sobremaneira. Dos livros que restaram em seu acervo pessoal há várias publicações. Dentre elas, a edição francesa de 1955: Mon Autobiographie e o livro de Hitchcock In the nature of materials (1958) que já foi

\footnotetext{
33 José Cláudio Gomes em depoimento à autora em 1 de junho de 2007

${ }^{34}$ LIMA, Luiz Gastão de Castro. Aula Prof. Gastão e Prof. Caron. EESC-USP. Aula gravada em vídeo-tape. CEDOC. EESC-USP. 199 ?.
} 
citado em trabalhos anteriores como o livro de cabeceira dos wrightianos da FAU.

Gastão atribui à sua geração certa ideologia e define a inclinação à Wright ou Corbusier não como uma aversão contrária a uma ou outra tendência. Era uma geração que buscava o moderno em todas as suas manifestações e não se limitava a ponto de fechar os olhos para outras arquiteturas.

A minha geração era uma geração ideológica. A ideologia não era nossa, mas nós encampávamos o pensamento do Niemeyer, nós encampávamos 0 pensamento do Corbusier, encampávamos 0 pensamento do Wright e aquilo era verdade para nós. A arquitetura era aquilo. Ou o brutalismo, ou outras coisas nesse sentido. ${ }^{35}$

Gastão continua admitindo inclusive seu olhar à arquitetura dos países escandinavos. Nesse contexto, estaria Alvar Aalto, que teria no conjunto de sua obra incorporado os conceitos da arquitetura orgânica de Wright:

Nós negávamos a cópia dos modelos do passado, negávamos todo esse conjunto de arquitetura, éramos até contra as arquiteturas ecléticas à medida que elas copiavam o passado, copiavam os gregos, copiavam os romanos. Nós achávamos que a verdade da arquitetura - e o Ruskin já havia dito a respeito, sete anos antes dessa arquitetura- a grande verdade da arquitetura estava nesses grandes modelos da Bauhaus, dos americanos, dos finlandeses.

Admitia que na época, a atenção restrita em torno desse núcleo os levou a se distanciar de outras

\footnotetext{
${ }^{35}$ LIMA, Luiz Gastão de Castro. Aula Prof. Gastão e Prof. Caron. EESC-USP. Aula gravada em vídeotape. CEDOC. EESC-USP. s/d.
} 
arquiteturas que aconteciam na América Latina e mesmo na Europa, dizia ele:

\begin{abstract}
Nós inclusive -e era muita ignorância nossa- não conhecíamos os espanhóis, ou conhecíamos muito pouco. Gaudi, por exemplo, passou a ser conhecido e estudado muito recentemente. (...)

(...) nós estávamos implantados no modernismo como um paradigma e nós fomos fazendo um pouco arquitetura de moda, arquitetura de grife.
\end{abstract}

\section{O embate racionalismo versus organicismo}

No Brasil dos anos 50 e 60, a construção civil vivia uma fase intensa de experimentação com espaço para inovações, onde os alunos aprendiam muito através das experiências nos canteiros.

$\mathrm{Na}$ época, a grande massa produtiva se concentrava no eixo Rio-São Paulo. No entanto, ao contrário do Rio de Janeiro, onde a maior parte das encomendas aos arquitetos modernos vinha do Estado, São Paulo dependia do capital privado para a viabilização de obras de maior envergadura. As duas correntes derivadas desta intensa produção viriam nortear a arquitetura dos anos seguintes na consolidação de duas linhas que permitiu a denominação por parte da historiografia de escola carioca e escola paulista. Esta última que se consolida em meados dos anos 50 foi, segundo Ruth Zein, "em oposição parcial à disseminação hegemônica da arquitetura carioca".(ZEIN 2001).

Em 1952, mesmo ano em que Lúcio Costa publica Considerações sobre arte contemporânea ${ }^{36}$, Vilanova

\footnotetext{
36 "Considerações sobre Arte Contemporânea". 1952 (texto publicado originalmente no 6o número de "Os cadernos de Cultura" do Serviço de Documentação do MEC. Reeditado em: Lúcio Costa: Sobre Arquitetura. 1ํㅡol. Centro dos Estudantes de Arquitetura Universitária . Porto Alegre, 1962.
} 
Cartão postal com indicação do caminho que levava à Brasília, onde se lê: "Brasília: A nova capital do Brasil: alguns contra, muitos a favor, todos beneficiados! Fundação da casa popular: programa habitacional Juscelino Kubitschek. 1a etapa: 500 casas". Fonte: acervo pessoal da autora
Artigas escreve Os Caminhos da Arquitetura Moderna ${ }^{37}$ e retoma a polêmica racionalismo versus organicismo, empregando as imagens mitológicas de Apolo se referindo a Le Corbusier e Dionísio, a Frank Lloyd Wright. No mesmo ano, no cenário internacional, a exposição wrightiana "Sixty Years of Living Architecture", inaugurada um ano antes em Gimbel's na Filadélfia, percorre Florença, Zurique, Paris, Munique e Rotterdam, enquanto um incêndio destrói parcialmente a Hillside Home School de Wright, em Spring Green.

Em nove de abril de 1959, então com 92 anos, Wright vem a falecer no Arizona. $\mathrm{Na}$ ocasião, os corbusianos da FAU-USP organizam o enterro simbólico do mestre norte-americano e fazem circular no meio acadêmico, artigos provocativos. Henrique Pait incentiva o grupo wrightiano a organizar uma exposição sobre as obras de Wright, o que acontece em outubro. Neste mesmo ano, Bruno Zevi vem ao Brasil para o Congresso Internacional de Críticos de Arte realizado em Brasília, Rio de Janeiro e São Paulo. Na ocasião, reitera as críticas feitas à nova capital federal. ${ }^{38}$

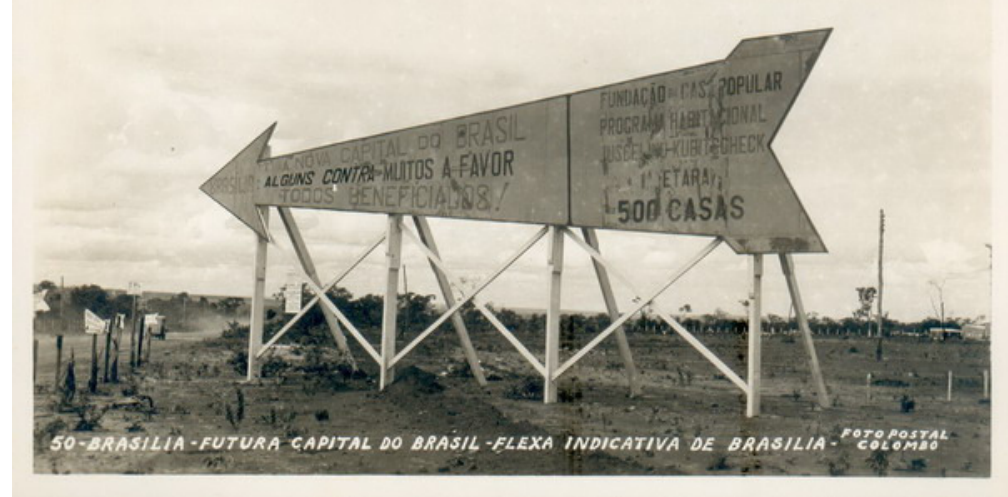

37 "Os caminhos da Arquitetura Moderna" (publicado na revista Fundamentos no 24 em Janeiro de 1952. Reeditado em: ARTIGAS, J. B. Vilanova. Caminhos da Arquitetura. São Paulo, Fundação Vilanova Artigas, 1986.

${ }^{38} \mathrm{Na}$ sua passagem por São Paulo, Zevi proferiu uma palestra na FAU- Maranhão retoamando o tema orgânicoXracional. 
No decorrer dos anos 60 uma série de artigos sobre as obras e as idéias de Frank Lloyd Wright circulam em periódicos nacionais, enquanto Juscelino Kubitschek inaugura Brasília, símbolo do racionalismo corbusiano.

Em 1961, o Jornal do Brasil, contando com apoio e assessoria do IAB (Instituto dos Arquitetos do Brasil), elabora um questionário sobre temas relativos à profissão do arquiteto. Dentre as perguntas, uma delas retoma o embate entre Wright e Corbusier:

"Que pensa das correntes organicista e racionalista como tendências da arquitetura contemporânea? Quais suas relações com a realidade brasileira?" (Inquérito Nacional de Arquitetura -1961)

De todos os convidados a participar do Inquérito (Sérgio Bernardes, Marcelo Fragelli, Henrique Mindlin, Oscar Niemeyer, os irmãos Roberto, Gregori Warchavichk, Lúcio Costa, Affonso Eduardo Reidy, entre outros) apenas dois se esquivam da resposta: Artigas e Rino Levi. A análise das respostas por si só daria margem à excelente pesquisa, uma vez que dentre todos arquitetos participantes do Inquérito, estes dois em especial, tiveram obras consagradas pela organicidade de influência wrightiana.

Internacionalmente, a partir da década de 60 a revisão crítica do paradigma chamado Racionalismo se intensificou. Os anos 60 ainda presenciariam debates e revisões nos currículos escolares e os efeitos da construção de Brasília levariam à expansão do ensino de arquitetura através da criação de novas escolas. 


\section{PRIMEIROS PASSOS}
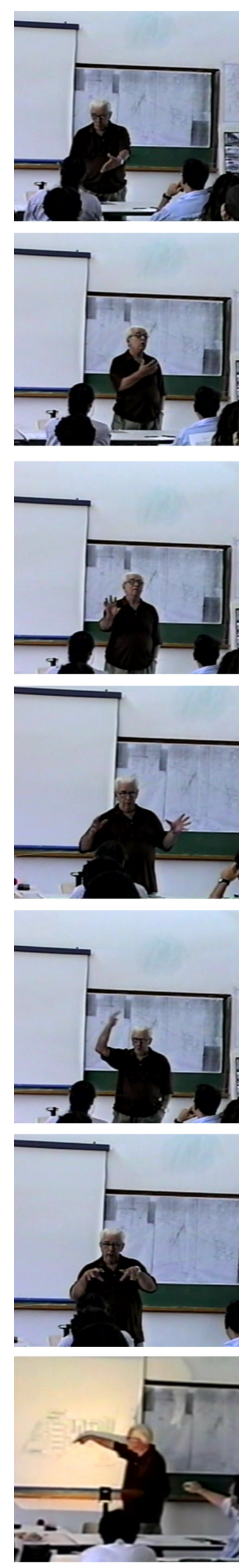
a maioria dos professores que integram a UNIVERSIDADE BRASILEIRA FOI ESCOLHIDA ENTRE OS ELEMENTOS POR ELA DIPLOMAdOS E, DE MANEIRA GERAL, SEM ATENTAR PARA SEUPREPARO NO ASPECTO DIDÁTICO.

COM EXCEÇÃO dOS PROFESSORES EGRESSOS DE FACULDADES QUE INCLUÍAM EM SEUS CURSOS DISCIPLINAS DE DIDÁTICA, OS DEMAIS POSSUIAM UNICAMENTE FORMAÇÃO PROFISSIONAL; TENDO, PORÉ, pOr alGUM MOTIVO, DESPERTAdo a ATENÇÃO, FORAM CONVIDADOS A PARTICIPAR DOS QUADROS DOCENTES.

E ASSIM O APRENDIZADO DO MAGISTÉRIO FOI FEITO A DURAs penas, calcado em grande dose de boA VONTADE-MAS, PRINCIPALMENTE, NO EMPIRISMO. 
Com uma intensa carreira acadêmica, Gastão assume bem cedo um compromisso com o ensino do desenho que o acompanhou durante todo tempo em que lecionou. Uma primeira experiência aconteceria ainda durante a graduação, numa escola da rede pública de São Paulo.

Em 1953 inicia sua experiência docente como professor secundário de Desenho no Ginásio da rede pública de ensino de Indianápolis, na Escola Estadual Professor Alberto Levi, onde leciona até 1956. Teria se influenciado nesse momento por um trabalho de Lúcio Costa publicado no primeiro número da revista Cultura, em 1948. O artigo abordava a problemática do ensino do desenho no curso secundário que na época passava por reformulações. Gastão diz ter se guiado pelo texto de Costa onde este se afirma mais como educador de vocação que como arquiteto consagrado, acentuando a importância das artes visuais no ensino e a transcendência do ensino das artes visuais. ${ }^{1}$

Esse mesmo pensamento seria encampado pelo arquiteto em sua postura como docente, colocando o desenho num patamar de ciência e entendendo-o como um sistema. Essa compreensão o levaria a pesquisar e colocar em prática novas metodologias de ensino do desenho que passou por uma severa crítica dos modelos acadêmicos adotados em todas as escolas de engenharia na época. Muitos desses modelos permanecem presentes nos cursos até hoje.

\footnotetext{
${ }^{1}$ LIMA, Luiz Gastão de Castro (1973). Pg 14. O artigo a que Luiz Gastão se refere é: COSTA, Lúcio. Ensino do Desenho. Cultura, Rio de Janeiro, 1(1):47-68, set.-dez. 1948
} 


\section{As bienais de Artes}

Luiz Gastão se forma em 1954, ano em que São Paulo vivia um clima de euforia por ocasião do seu IV Centenário. A data não comemorava apenas os quatrocentos anos da cidade que mais cresce no país, mas também o $22^{\circ}$ aniversário do início da Revolução Constitucionalista de 1932. Como se não bastasse, sediava a segunda edição da Bienal de Artes inaugurada no fim do ano anterior, tendo como palco o Parque do Ibirapuera.

A Bienal atraiu mais uma vez a atenção internacional e nomes importantes da arte e da arquitetura. Estiveram no Brasil naquela ocasião, Gropius, Aalto e Ernesto Rogers. Nesta edição, a presença norte-americana predominou. Mais de um terço das obras expostas e mais da metade das residências individuais vinham dos Estados Unidos. Algumas publicações posteriores à mostra destacaram os efeitos que os projetos americanos teriam causado nos estudantes e arquitetos brasileiros que visitaram a exposição. Em especial, um artigo publicado na revista Habitat já chamava a atenção para uma linguagem modesta, que se apresentava flexível, não se dobrando a dogmatismos. $^{2}$

A edição da Bienal em 1955 seguiu linha semelhante.

$\mathrm{Na}$ quarta edição do evento em 1957, a Bienal recebeu Kenzo Tange, Marcel Breuer e Philip Johnson. Desta vez foi realizada no Pavilhão das Indústrias, sua sede definitiva. Novamente os Estados Unidos participam com um quarto das obras residenciais individuais. Dos participantes brasileiros, muitos exibiam projetos

\footnotetext{
${ }^{2}$ Para onde vai a arquitetura? Habitat, São Paulo, n.14,p.25, fev.1954
} 
reverberantes com a arquitetura americana dentre eles, Oswaldo Bratke, Plínio Croce, Ortenblad Filho, Galiano Ciampaglia, Miguel Forte. Estes últimos ficaram conhecidos pela fidelidade ao ideário wrightiano.

Após ter vivido um primeiro momento de industrialização entre os anos 20 e 30 e sentido os efeitos do movimento modernista durante o Estado Novo (1937-45) o Brasil vivia nos anos 50, um segundo momento industrial promovido pelo governo desenvolvimentista de Juscelino Kubitschek.

Embora houvesse uma necessidade de tecnologia importada num primeiro momento, as medidas tomadas no sentido da industrialização nacional guardavam em si a esperança de uma autonomia vindoura decorrente do desenvolvimento nacional. $O$ contexto cultural vigente gerou boa repercussão da produção artística e arquitetônica do país no panorama mundial e permitiu maior intercâmbio entre o Brasil e os países da América Latina. 


\section{Escolhas profissionais}

Em 1955, depois de um ano de formado, Gastão viaja ao Peru a convite do Arquiteto Fernando Belaunde Terry, na época Diretor da Faculdade de Lima e que mais tarde viria a se tornar presidente daquele país. $\mathrm{Na}$ ocasião visita também a Argentina e o Chile, a fim de documentar a arquitetura produzida nos dois países. Logo após a viagem, recebe a notícia do deferimento de uma bolsa de Estudos do governo Italiano, para freqüentar o Curso de Desenho Industrial na Faculdade de Arquitetura da Universidade de Florença. Apesar da concorrência pela bolsa, Gastão a recusa. Numa carta à Instituição, justifica a desistência por motivos de força maior. ${ }^{3}$

Apesar da recusa ao curso na Itália, a relação de Gastão com o desenho e suas implicações na arquitetura e no ensino estariam definitivamente consolidadas. Desde o primeiro instante de sua formação, o comprometimento com a linguagem e com a representação gráfica foi fio condutor de sua atuação profissional.

Em 1956, a convite de José Maria da Silva Neves, Gastão é contratado como seu assistente junto à cadeira no 22 de Composição Decorativa da Faculdade de Arquitetura e Urbanismo da USP, na mesma época que Nestor Goulart e Lúcio Grinover, ficando vinculado à instituição até 1972. Segundo depoimento do arquiteto, os três teriam sido os primeiros ex-alunos a serem contratados como docentes pela FAU.

\footnotetext{
${ }^{3}$ Carta integrante do acervo do arquiteto. LIEP-UFSCar. Possivelmente sua decisão estaria associada ao nascimento de sua segunda filha, que ocorreria no ano seguinte. Muitos de seus contemporâneos freqüentariam o curso nos anos subseqüentes.
} 


\section{A reforma no ensino de Arquitetura}

Já nos idos da década de 50, nem todos optavam pela profissão de arquiteto por vocação. A Faculdade de Arquitetura da USP atraia a elite intelectual e artística paulistana e começava a se configurar como cenário das discussões de cunho democrático e socialista.

Já na época, a FAU se esboçava como um centro cultural que reunia cenógrafos, pintores e compositores. Este cenário só mudaria anos mais tarde, com a criação da Escola de Comunicação e Artes, quando a FAU deixaria de abrigar todas as manifestações culturais e a ECA passaria também a absorver boa parte dos alunos ingressantes na USP com vocações diversas.

A partir de 57, foram promovidos vários encontros nacionais entre arquitetos, professores e alunos onde se debateu acerca da necessidade de formular um currículo mínimo para os cursos de arquitetura. Aos poucos, uma abertura foi sendo notada no seio da Universidade. Esse processo foi acontecendo gradualmente e teve grande impulso a partir da contratação de ex-alunos para o quadro docente, culminando com a reforma curricular encabeçada por Vilanova Artigas em 1962. Essa reforma inicialmente buscou desvincular a Faculdade de Arquitetura dos moldes técnicos iniciais, permitindo uma evolução que consolidou a FAU como referência internacional.

Um dos passos mais significativos da reforma foi a incorporação do desenho industrial e da comunicação visual na grade curricular. Estas disciplinas seriam veio condutor da atuação acadêmica de Luiz Gastão a partir dessa fase.

Na década de 60, fazíamos então a formulação do ensino de arquitetura em São Paulo. (...) De acordo com a minha visão de mundo, a escola deveria abrir 
espaço para a pesquisa entre professores e alunos em torno da qual se daria o planejamento geral do meio ambiente. Isto não significava única e exclusivamente fazer casas e colocá-las na paisagem, mas abrangia o desenho industrial e a comunicação visual. ${ }^{4}$

Docente na Instituição desde 1957, Gastão participou da reforma assumindo desde então, um papel singular no meio acadêmico.

Dois anos depois que eu terminei o curso,
praticamente verde ainda, eu tive a ousadia de
ingressar no corpo docente da FAU, inicialmente
numa disciplina que foi extinta pela reforma de 62 :
chamava-se "Composição Decorativa". Uma
disciplina que ninguém sabia bem para que servia,
mas era dos currículos antigos de arquitetura.
Uns entendiam que era arquitetura de interior, outros
entendiam que seria arquitetura de móveis. Extinta
essa disciplina, eu ingressei através dessa
curiosidade que eu tinha, na área de Desenho
Industrial, durante alguns anos e, depois em
Comunicação Visual. ${ }^{5}$

Após a reforma curricular, a cadeira de Composição Decorativa viria a se chamar Desenho Industrial. Seguindo por essa linha, segundo o próprio Artigas, o arquiteto devia ser visto como humanista, "capaz de projetar o produto e a embalagem" e acompanhar o desenvolvimento da indústria paulista.

O próprio curso de Desenho Industrial e Comunicação Visual que eu pensei para os

\footnotetext{
${ }^{4}$ Vilanova Artigas. In XAVIER, Alberto. Depoimento de uma geração: arquitetura moderna brasileira. São Paulo, Cosac \& Naify, 2003.pg 218

5 Luiz Gastão de Castro Lima. In INSTITUTO DOS ARQUITETOS DO BRASIL - São Paulo. Arquitetura e desenvolvimento nacional: depoimentos de arquitetos paulistas. Pini, São Paulo, 1979. $\mathrm{Pg} 78$
} 
estudantes da Faculdade de Arquitetura e Urbanismo da USP (FAU-USP) formaria o conjunto humanístico que, creio, deveria caracterizar a cabeça do arquiteto e o planejamento geral do meio ambiente. ${ }^{6}$

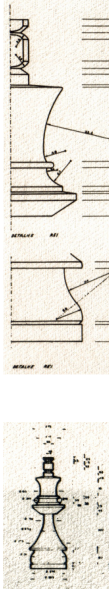

(2)

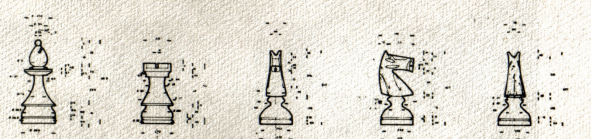

(ㅇ) 0 (1)

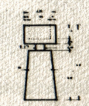

(D)

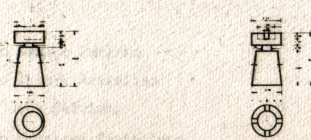

Acima, peças e tabuleiro de xadrez. Desenhos de alunos do terceiro ano da FAU no curso de Desenho Industrial em 1962.

Com a reforma curricular, o curso de arquitetura da FAU passa a se estruturar a partir de quatro seqüências: projeto, planejamento, desenho industrial e comunicação visual. Essas duas últimas se consolidariam como espinha dorsal da linha de pesquisa empreendida por Luiz Gastão ao longo de toda sua vida docente.

Nesse mesmo momento se organizam os departamentos de projeto, de ciências e técnicas (que se agrupariam posteriormente em um único departamento de tecnologia) e o de história e crítica, que mais tarde passaria a se chamar Departamento de História da Arquitetura e Estética do Projeto (AUH), incorporando o acervo do Centro de Estudos Folclóricos do Grêmio da Faculdade e absorvendo como docentes muitos dos exalunos envolvidos nas investidas iniciais do grupo do Folclore. Entre eles, Luiz Gastão, João Walter Toscano, Nestor Goulart, Júlio Katinsky e Benedito Lima de Toledo.

As técnicas de representação gráfica, alvo de intenso interesse de Luiz Gastão, se refletiriam anos mais tarde numa extensa pesquisa sobre metodologias para 0 ensino do desenho. Esta pesquisa, resultado de um estudo aprofundado da produção industrial, buscava a unificação dos processos de criação e industrialização, integrando Universidade e Indústria, um caminho trilhado com base nos conceitos colocados por Artigas durante a reformulação do ensino. Gastão aprofundaria o tema na teoria e na prática, na sua tese de doutoramento e na aplicação dos métodos propostos pela pesquisa na Escola de Engenharia de São Carlos, na Faculdade de

\footnotetext{
${ }^{6}$ ARTIGAS, Vilanova: Depoimento. In Xavier, Alberto. Depoimento de uma geração: arquitetura moderna brasileira. São Paulo, Cosac \& Naify, 2003.Pg 218
} 
Arquitetura da USP e da UNESP e na estruturação do curso de Engenharia de Produção da Universidade Federal de São Calos. ${ }^{7}$
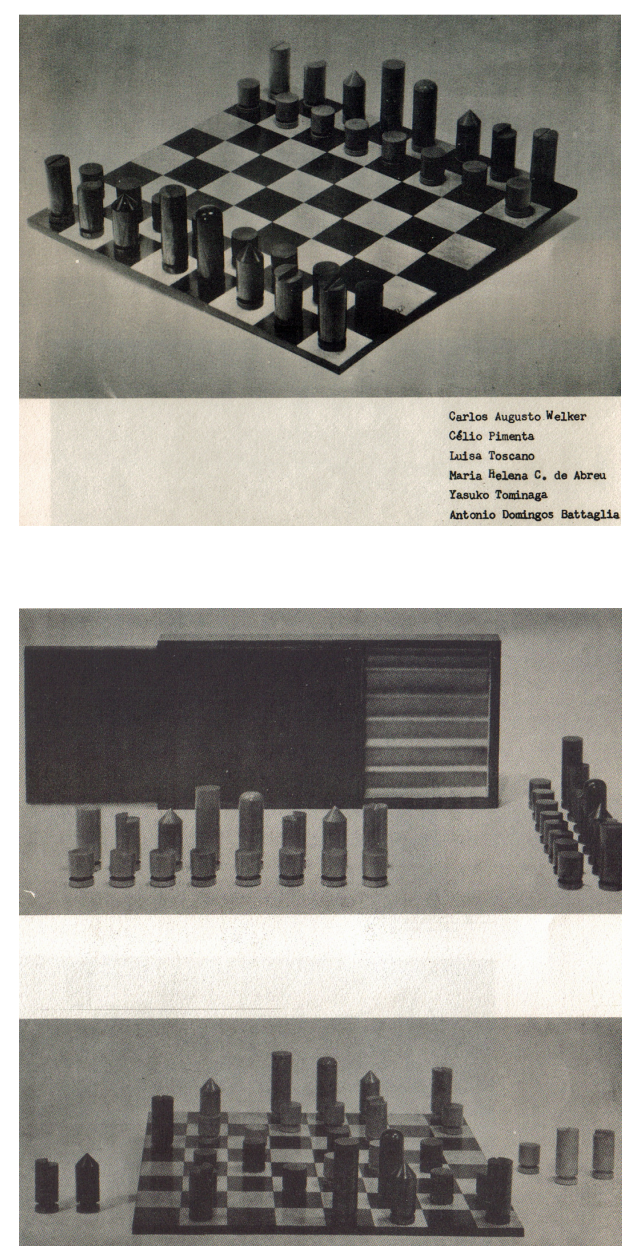

Produto final do trabalho desenvolvido pelo grupo dos alunos da FAU Domingos Bataglia e Carlos Welker, na disciplina Desenho Industrial.

Fonte: UNIVERSIDADE DE SÃO PAULOSeqüência de desenho industrial (1963).

\section{O ensino do Desenho}

Paralelamente às mudanças na FAU, Luiz Gastão dá os próximos passos em direção aos estudos tecnológicos, e participa ainda em 1962 do Seminário "Lineamento com o emprego de cônicas e tecnologia dos plásticos reforçados com fibra de vidro". Realizado nas dependências da EESC, este seminário teve como objetivo o treinamento de pessoal para montagem da Seção de Plásticos da FAU, anexa às cadeiras de Desenho Industrial e Comunicação Visual.

O ano de 1962 foi um marco na Faculdade de Arquitetura da USP. A reforma curricular propôs uma reformulação geral que visou dar ao ensino nova estrutura, mais flexível, que pudesse dar conta das novas solicitações no campo da arquitetura. Das principais modificações, a inclusão das novas disciplinas de Desenho Industrial e Comunicação Visual teve papel decisivo na formação dos alunos. Deu-se início a um processo de estudo e desenvolvimento de uma metodologia de ensino que passou pela análise do objeto e sua representação até uma completa reformulação de uso. Recursos externos foram mobilizados com 0 envolvimento direto da indústria. Luiz Gastão, ao lado de José Maria da Silva Neves e Abrahão Sanovicz foi um dos docentes responsáveis pelos trabalhos junto à turma do terceiro ano de arquitetura da FAU. Propuseram na

\footnotetext{
${ }^{7} \mathrm{Na} F A U$, os trabalhos realizados com a turma do terceiro ano por Luiz Gastão de Castro Lima, ao lado de Abrahão Sanovicz e José Maria da Silva Neves, foram publicados em UNIVERSIDADE DE SÃO PAULO. Faculdade de Arquitetura e Urbanismo. Departamento de Projeto. Desenho Industrial 1962. Seqüência de desenho industrial. Publicação 8. 1963
} 

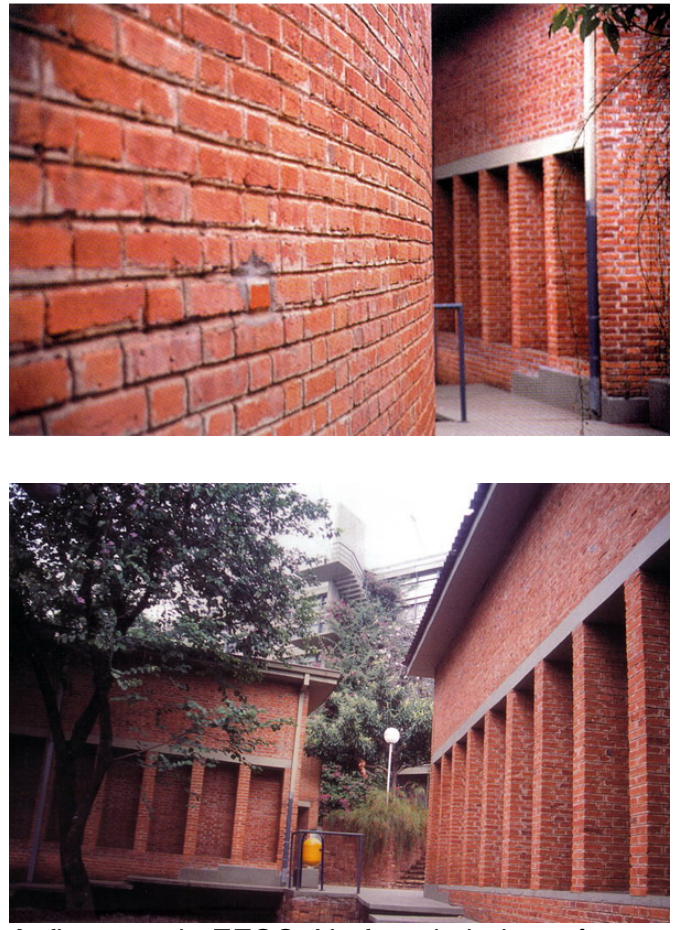

Anfiteatros da EESC. Na foto de baixo, vê-se ao fundo, o E-1. Fonte: Lanna (2005) disciplina um novo estudo para um jogo de xadrez envolvendo o projeto das peças, do estojo e do tabuleiro. Situando o tema no campo do Design, os alunos deveriam partir do desenho técnico das peças existentes a fim sentirem as reais proporções estabelecidas pelo uso e a partir daí, elaborar nova proposição dentro de um conceito moderno.

Dentre os trabalhos realizados pelos alunos, certamente lhe chamou a atenção o de Carlos Welker e Antonio Domingos Bataglia. Gastão seria o responsável pela contratação de ambos, junto ao quadro docente da EESC em 1969, propiciando abertura de novas turmas nos cursos de desenho oferecidos pela escola e a continuidade dos trabalhos que estavam sendo feitos no tocante ao ensino do desenho dentro da Escola de Engenharia de São Carlos.

\section{Retorno à cidade natal}

O Gastão já se fazia notar porque nunca deixou de ser o arquiteto do interior no sentido de não ficar seduzido pela metrópole. A metrópole era algo muito importante na época, aquela quantidade de informação e de cultura, mas o Gastão era tipicamente o cara que o arranjo do interior, o fato de ter alguns amigos, era melhor do que ficar se batendo na capital. ${ }^{8}$

A Escola de Engenharia de São Carlos (EESC), criada em 1953, foi proposta pelo deputado Miguel Petrilli que defendia sua implantação desde 1947. Na época de sua fundação, a cidade contava com pouco mais de 70 mil habitantes e uma intensa atividade fabril.

Bem servida por estradas de ferro, São Carlos já representava o progresso de uma cidade totalizadora.

\footnotetext{
${ }^{8}$ Araquém Martinho em depoimento à autora.
} 
Em discurso na Assembléia Legislativa em agosto de 1947, Petrilli defende a implantação de universidades no interior e valoriza as potencialidades da cidade de São Carlos, induzindo à continuação da instrução primária e secundária que já servia toda a região. ${ }^{9}$ Num primeiro momento, o projeto é vetado pelo então governador Adhemar de Barros, sendo aprovado somente cinco anos mais tarde. Nos primeiros cinco anos, a EESC funcionou no imponente edifício da Rua Nove de Julho cedido pela Societá Dante Alighieri. A partir de 1958, iniciadas as obras em gleba doada pelo poder público municipal, a Escola de Engenharia inicia a construção de um campus universitário.

Em 1960, Luiz Gastão decide se transferir com a família para São Carlos. O retorno à cidade natal representava muito mais do que poderia parecer num primeiro momento. Desde sua formatura, Gastão vinha trabalhando com projetos em São Paulo, pois não tinha vínculos que demandavam exclusividade com a FAU.

Trabalhei, inclusive, já na FAU, com um professor de paisagismo que era o Roberto Coelho Cardoso; trabalhei com ele e com o Jorge Wilhem também. E, tive escritório, fiz alguns projetinhos... ${ }^{10}$

No entanto, a sobrevivência dentro dos limites profissionais não era tarefa fácil. Por muitas vezes desenvolveu atividades pouco ligadas à sua formação de arquiteto.

Durante algum tempo (...) trabalhei como franco atirador e também em escritório de arquitetura. Ao mesmo tempo em que lecionava na FAU, montava amplificadores de alta-fidelidade e vendia automóveis. Vê-se que a atuação profissional também não era das mais brilhantes naquela

\footnotetext{
${ }^{9} \mathrm{Na}$ época, existiam em São Carlos cerca de 70 escolas primárias e a Escola Normal.

${ }^{10}$ Luiz Gastão de Castro Lima em entrevista a TANASHIRO (2003) p233
} 


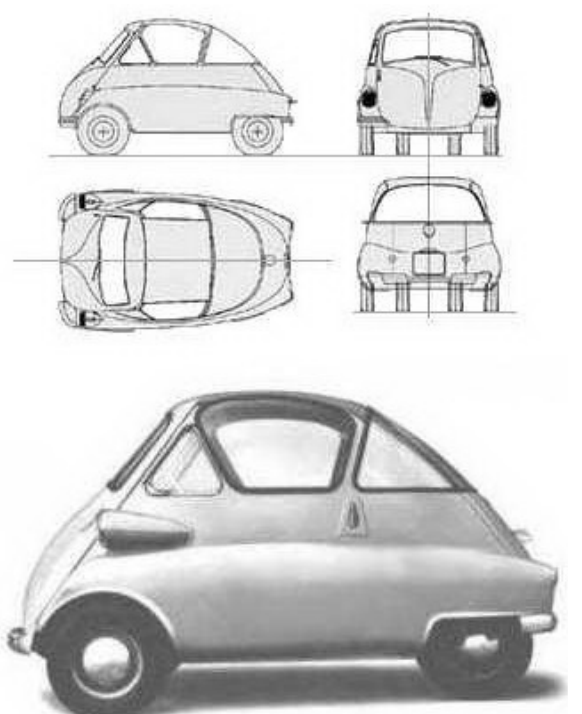

Romi-Isetta. Fonte: Acervo pessoal. ocasião. Tocava gaita também. Havia uma dificuldade profissional que tem marcado geração após geração, as nossas atividades. ${ }^{11}$

Luiz Gastão nutria uma paixão especial por automóveis que compartilhava com o mestre Frank Lloyd Wright. Esta paixão o levou a comercializá-los durante algum tempo em São Paulo. Foi um dos primeiros paulistanos a possuir uma Romi-lseta, primeiro automóvel fabricado inteiramente no país e que inaugurou a indústria automobilística nacional em 1956.

O Gastão chegou em São Carlos nos anos 1960. Ele tinha uma raridade na época, uma Romi-iseta. A Romiiseta é dos anos 50 e era fabricada pela Romi em Piracicaba. Foi um carrinho que teve poucos anos de vida. Imagino que deva ter sido uma epopéia subir a serra de Rio Claro naquele carrinho. Ele gostava muito de carros. Tinha carros mais novos, mas conservava carros antigos. Teve também um Volkswagen modelo TL na cor verde abacate, mas o carro preferido do Gastão durante muitos e muitos anos, foi um Dodge modelo Polara na cor creme. "12

Em vias de nascer sua terceira filha, Gastão conta as razões de sua decisão em voltar ao interior:

Nessa altura, aconteceu o segundo fato ao qual eu fiz referência e que marcou profundamente a minha vida. Eu resolvi me transferir para o interior do estado, um pouco para retornar às atividades integrais de arquitetura. (...) realmente eu tinha me afastado bastante da arquitetura. Foi uma tentativa de retomar essa linha, um pouco para viver melhor com o mesmo dinheiro (...) e um pouco por tendência bucólica que acho que todos

\footnotetext{
${ }^{11}$ Luiz Gastão de Castro Lima in Instituto dos Arquitetos do Brasil (1979).

${ }^{12}$ Alfeu Rohm em depoimento à autora. Segundo depoimento de Flávia de Castro Lima, Gastão se desfez da Romi-Iseta em 1957, mas antes de se transferir definitivamente para São Carlos, veio em férias com a família no pequeno automóvel.
} 
nós temos, assim meio subjacente de campo, de interior. $^{13}$

O fato de ter nascido em São Carlos foi fator preponderante para definir o destino de Gastão ao sair da capital. Em 1960, a cidade já detinha a fama de capital da tecnologia e ostentava o título de "Athenas Paulista" dado o grande número de instituições de ensino presentes na cidade. Era na época uma das poucas cidades do interior servida por um sistema de transporte coletivo feito por bondes elétricos. Gastão afirma que apesar do perfil tecnológico que sustentava sua fama, São Carlos ainda se via presa à estrutura tradicional do café e detinha vínculos de uma forte tradição ligada ao campo.

Gastão se lembra que:

Realmente [São Carlos] era uma cidade que, apesar de toda essa pujança industrial possível, ainda era bastante atrasada, bastante provinciana e havia muito pouco trabalho na profissão de arquitetura.

$\mathrm{Na}$ realidade, durante algum tempo eu trabalhei pouco em São Carlos. Tive algum serviço e continuei na FAU

A Escola de Engenharia já estava criada, mas trabalhava no limite de uma infra-estrutura deficitária.

Embora já contasse São Carlos com um parque industrial naquela ocasião, que tinha mais ou menos cem, indústrias (...) e uma unidade da USP, a Escola de Engenharia de São Carlos, escola naquela época muito prestigiada, era ainda bastante precária.

Segundo Gastão, não era tarefa difícil na época, trabalhar em São Paulo morando há 250 quilômetros de

${ }^{13}$ Luiz Gastão de Castro Lima. In Instituto de Arquitetos do Brasil. Depoimento de Arquitetos Paulistas. Muitos arquitetos formados em São Paulo migraram para o interior do estado difundindo 
distância. A linha férrea da Companhia Paulista de Estradas de Ferro já servia São Carlos e região. Conhecida pela pontualidade das viagens, segundo 0 arquiteto, era possível inclusive "acertar o relógio pelo apito do trem".

Luiz Gastão de Castro Lima foi o segundo arquiteto a vir para São Carlos. Quando chegou em 1960, já atuava na cidade o arquiteto Alexandre Arsênio, que segundo relatos, havia trabalhado na equipe de Oscar Niemeyer em Brasília. A trajetória de Arsênio foi precocemente interrompida por um acidente que o teria comprometido intelectualmente. A partir daí, sua produção deixou de lado a expressividade.

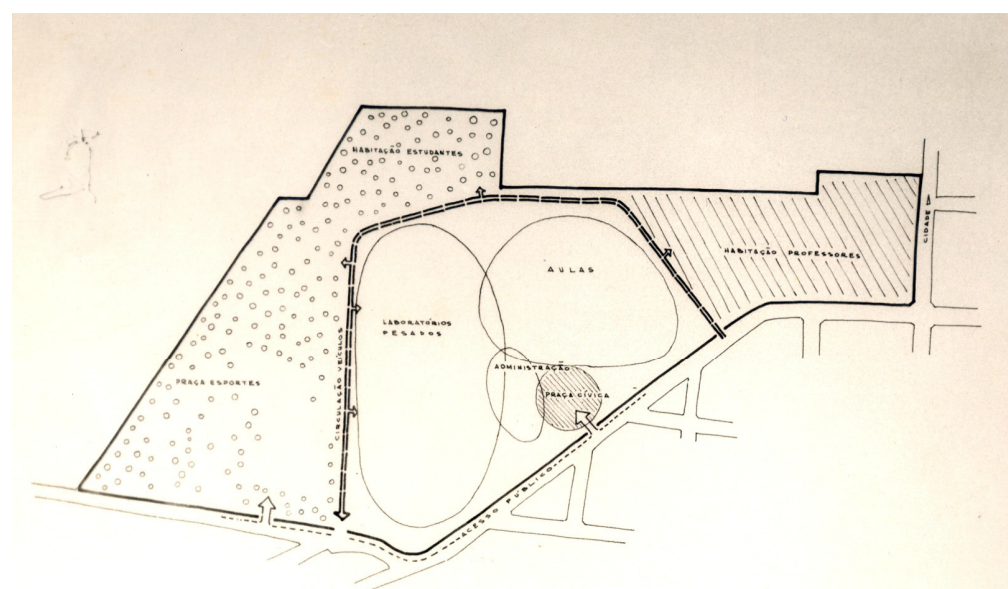

Plano diretor EESC -USP 1957. Fonte: Fundusp 


\section{Os edifícios da EESC e o Governo Carvalho Pinto}

Pouco menos de um ano depois de ter retornado à São Carlos, Luiz Gastão é indicado por Theodureto de Arruda Souto, então diretor da Escola de Engenharia, para acompanhar as obras no campus, ainda em vias de implantação. O planejamento inicial ficara a cargo do engenheiro Ernst Robert de Carvalho Mange e do arquiteto Hélio Duarte.

Formado em 1930 pela ENBA, Hélio Duarte havia sido professor na Escola de Belas Artes em Salvador, levando ao curso idéias de Le Corbusier e sendo responsável pelo projeto de alguns edifícios que estão entre as primeiras obras modernas da capital baiana. Transferiu-se para São Paulo em 1944 e como professor da FAU, foi orientador da tese de doutorado de Luiz Gastão.

A partir dos anos 60, Ernst Mange, que havia estagiado com Le Corbusier, desenvolveria por meio de seu escritório Planemak, projetos para a usina de Jupiá na divisa de São Paulo com o Mato Grosso e para a hidrelétrica de Ilha Solteira, além do projeto urbanístico da cidade, esta que foi segundo Hugo Segawa, a primeira experiência de criação de um aglomerado urbano. (SEGAWA 1998.pg 166)

Também de autoria da dupla Duarte e Mange é o projeto do primeiro edifício da EESC que ficou conhecido como E-1. Este deveria servir de modelo para os demais edifícios que seriam construídos, daí o seu nome. 0 andamento das obras nos anos seguintes não cumpriu a reprodução do E-1 proposta inicialmente, ficando este como único exemplar de uma arquitetura corbusiana.

O E1 segue os preceitos apresentados na Carta de Atenas e foi o primeiro edifício moderno de expressão racionalista construído na cidade. Dentre as várias 
razões que justificaram a sua não reprodução em série, estava o custo elevado da execução que envolvia não apenas fundações especiais, mas grandes áreas de impermeabilização. Sob este aspecto, o edifício levantou polêmicas no meio acadêmico, que por sua vez ofereceu resistência em manter 0 planejamento inicial desenvolvido pelo escritório paulistano, ainda que com meritórios acertos. Como arquiteto do campus, Luiz Gastão se envolveu por diversos momentos em tentativas de suprir as deficiências construtivas do edifício e seus problemas ambientais.

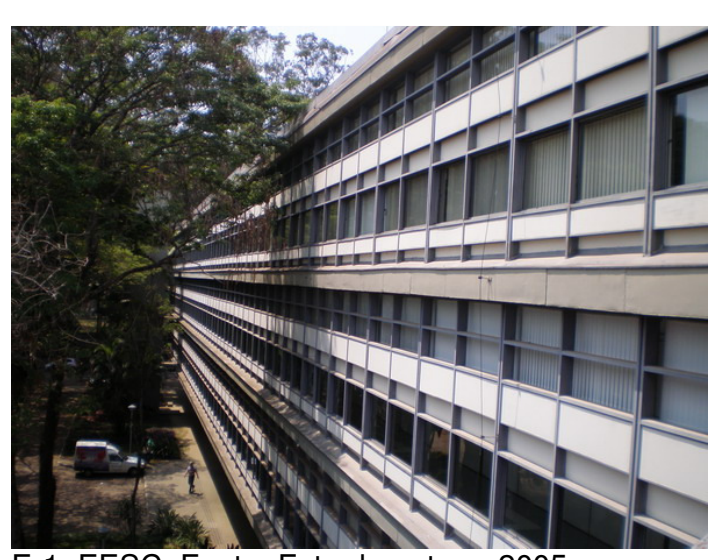

E-1. EESC. Fonte: Foto da autora, 2005
Infelizmente, analisando o prédio em si, havia alguns problemas ambientais com relação ao calor, defeitos de construção, alguns caixilhos tinham vazamentos. Eu, por muitas vezes tentei tirar esses vazamentos, mas não era muito fácil. Os caixilhos foram os primeiros feitos em chapa dobrada e a firma que os fez ainda não tinha experiência para resolver certos problemas de água.

Nós copiamos os modelos europeus sem copiar a tecnologia adequada.

Por muitos motivos, esse prédio não era aceito pela comunidade acadêmica, de jeito nenhum, a turma detestava esse prédio. Era um modelo, era um monumento, mas todo mundo o detestava. ${ }^{14}$

Presidida por Hélio Duarte, a Comissão de Construção da Cidade Universitária Armando Salles de Oliveira (que mais tarde viria a se tornar Fundusp) contava com a participação do arquiteto Paulo de Camargo e Almeida. Formado no Rio de Janeiro e consciente da realidade do E-1, Camargo e Almeida, junto ao corpo de arquitetos da Cidade Universitária, refaz o planejamento do campus da EESC. Esta nova proposta resultou nos prédios executados posteriormente

\footnotetext{
${ }^{14}$ Luiz Gastão de Castro Lima em LIMA, Luiz Gastão de Castro. Aula Prof. Gastão e Prof. Caron. EESC-USP. Aula gravada em vídeo-tape. CEDOC. EESC-USP. S/d
} 
incorporando em parte, a técnica de cobertura em placas pré-moldadas de argamassa armada desenvolvida na escola naquele momento. ${ }^{15}$

Como arquiteto do campus, Luiz Gastão se viu na posição de absorver a técnica, mas tratou de aferir aos edifícios um elemento que se tornaria constante em sua arquitetura: o uso do tijolo aparente.

Foi nessa altura que eu fui contratado. Eu vim fazer um trabalho de arquiteto um pouco cativo, eu tinha que seguir certas diretrizes que tinham vindo definidas pelo pessoal da cidade universitária. Então, eu simplesmente vesti os prédios, aí usando um pouco daquela minha veia wrightiana assim meio escondida, que nem aqueles ícones de computador que ficam atrás da tela...

Eu tinha um ícone dentro de mim, que era a minha paixão pelo Wright, que eu confesso, mantenho até hoje. $^{16}$

$\mathrm{Na}$ ocasião de ingresso na EESC, Gastão vinha trabalhando em São Paulo, dando aulas na FAU e realizando outras atividades pouco ligadas à arquitetura. Sua contratação pela Escola de Engenharia tratava de suprir a demanda de obras oriundas dos investimentos promovidos pelo Plano de Ação do Governo Carvalho Pinto.

Ao tomar posse em 1956, Juscelino Kubitschek lança um audacioso Plano de Metas com o lema desenvolvimentista "50 anos em 5". Este plano culminaria com a implantação da nova capital sobre o planalto central, quatro anos depois.

${ }^{15} \mathrm{O}$ arquiteto Paulo de Camargo e Almeida foi o criador do Mestrado em Industrialização da Construção do Departamento de Arquitetura e Planejamento da Escola de Engenharia de São Carlos da USP. Sobre o arquiteto, ver CERÁVOLO, Ana Lúcia. Paulo de Camargo e Almeida. Arquitetura Total na trajetória profissional de um arquiteto brasileiro. Dissertação de Mestrado, EESC-USP, São Carlos, 2000.

${ }^{16}$ LIMA, Luiz Gastão de Castro. Aula Prof. Gastão e Prof. Caron. EESC-USP. Aula gravada em vídeo-tape. CEDOC. EESC-USP. (data provável 1997) 
Com Jânio Quadros no governo do Estado e Carlos Alberto A. de Carvalho Pinto como secretário de finanças, é dado início às medidas do Plano de Metas em São Paulo, com foco na aceleração da industrialização com base na atração de capital estrangeiro. Muitas dessas ações beneficiaram diretamente o estado paulista, que com 0 forte crescimento industrial, aumentou a concentração de crédito, contribuindo em parte para a redução do déficit deixado por governos anteriores.

Ainda que a custo de novas dívidas, o governo de Jânio Quadros aumentou o número de estradas pavimentadas no estado, projetou novas usinas hidrelétricas (Furnas, Três Marias) e realizou diversas obras em outras já em operação (Paulo Afonso), além de ampliar a rede de saneamento básico e abastecimento de água. Outro setor beneficiado foi a área de educação, que tinha como um dos objetivos um programa de alfabetização e a ampliação de escolas de nível superior.

Ao assumir o governo do estado em 1959, Carvalho Pinto lança seu Plano de Ação, como parte da política nacional de desenvolvimento. A elaboração do plano contou em parte com a equipe de pesquisa urbana da Sociedade de Análise Gráfica e Mecanográfica Aplicada aos Complexos Sociais (SAGMACS). O sucesso do Plano de Ação foi em grande parte atribuído aos trabalhos da SAGMACS, que propunha intervenções após análise das potencialidades e tendências de urbanização.

As medidas do governo Carvalho Pinto (1959-63) também propiciaram a criação de várias instituições, dentre elas, a FAPESP (Fundação de Amparo à Pesquisa do Estado de São Paulo), o FECE (Fundo de Construção da Cidade Universitária) e o Cuaso (Fundo 
de Construção da Cidade Universitária Armando Salles de Oliveira), além de investimentos em obras civis nas áreas de educação, saúde e abastecimento. A Escola de Engenharia de São Carlos se beneficiou dentre outros recursos, da construção de edifícios de apoio didático, entre eles os anfiteatros e salas de aula, alojamento para estudantes, Centro Acadêmico e as primeiras instalações do Departamento de Física, todos de autoria de Luiz Gastão de Castro Lima.

Camargo e Almeida foi autor do prédio que abrigou o Departamento de Engenharia Mecânica. Este que foi o primeiro edifício erguido utilizando a técnica de cobertura em placas de argamassa armada.

Gastão se mostrou resistente ao uso da técnica que vinha sendo feita de forma experimental e apresentando muitos problemas principalmente relativos à infiltração. 


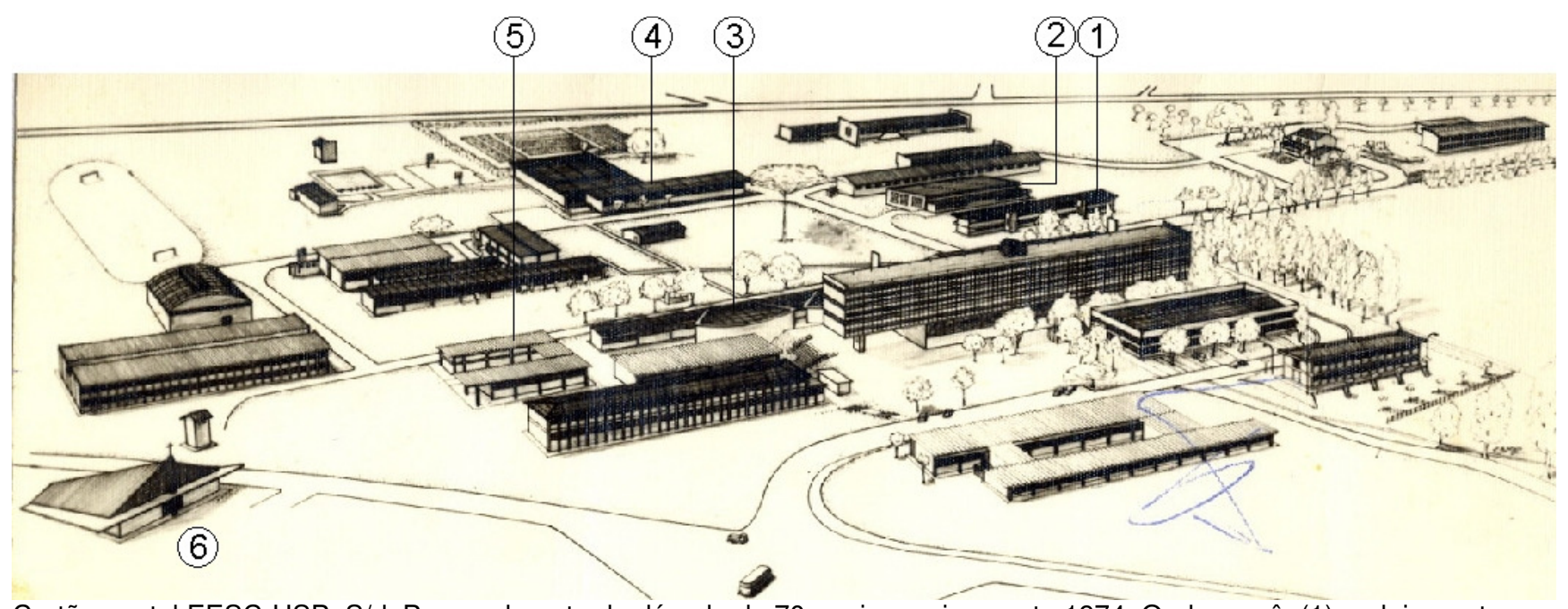

Cartão postal EESC-USP. S/d. Provavelmente da década de 70, mais precisamente 1974. Onde se vê: (1) o alojamento, (2) a biblioteca, (3) os anfiteatros e salas de apoio, (4) o restaurante e centro social, (5) o Instituto de Física. Na área externa ao campus, (6) a Igreja N. S. de Fátima. Todos projetados por Luiz Gastão. Fonte: Fundusp

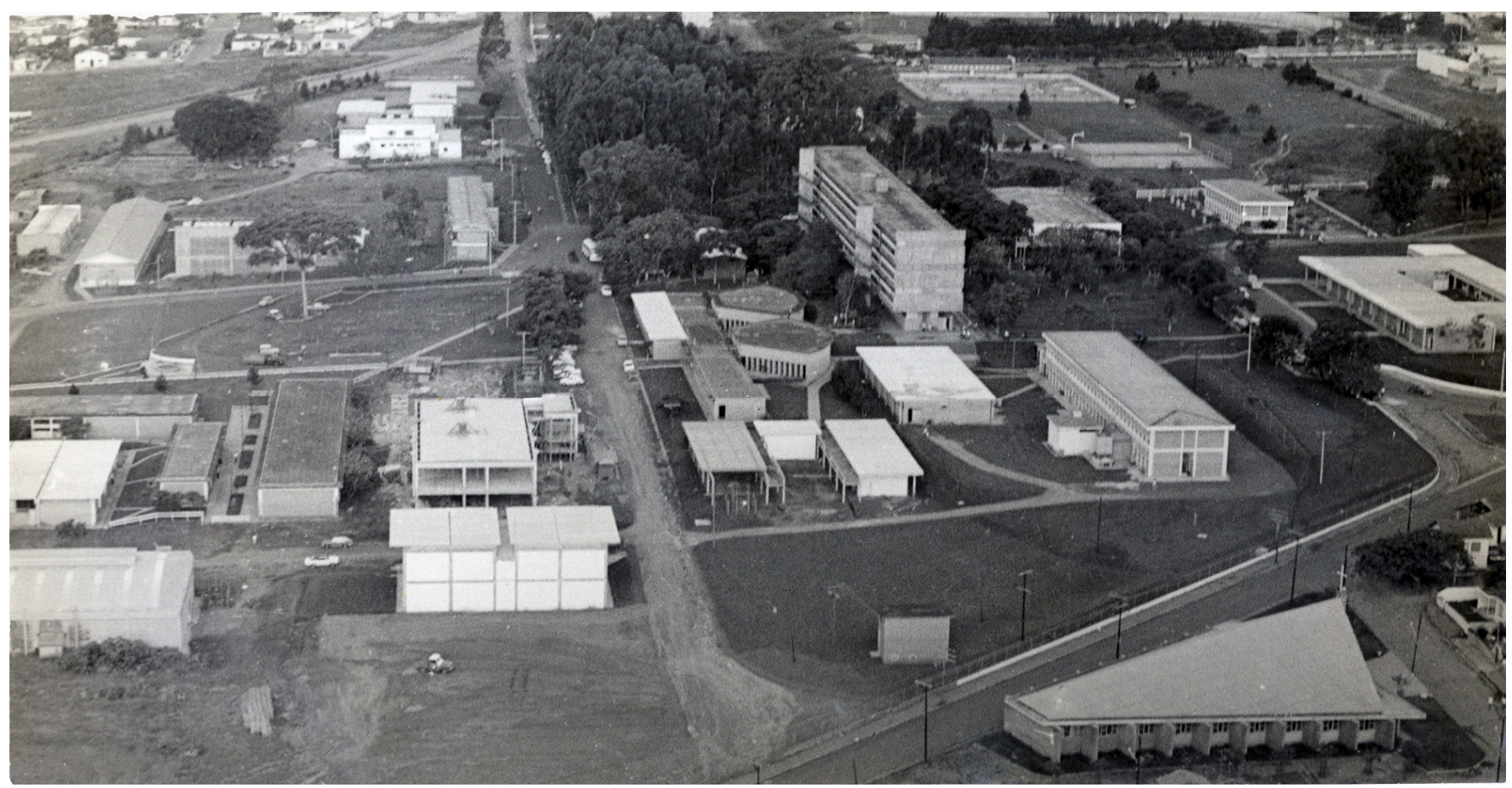

Foto aérea EESC-USP-1974. Onde se vê: o alojamento, a biblioteca, os anfiteatros e salas de apoio, já com o primeiro acréscimo, o Instituto de Física. E em primeiro plano, em área externa ao campus, a Igreja N. S. de Fátima, recém construída. Todos projetados por Luiz Gastão. Fonte: Fundusp 


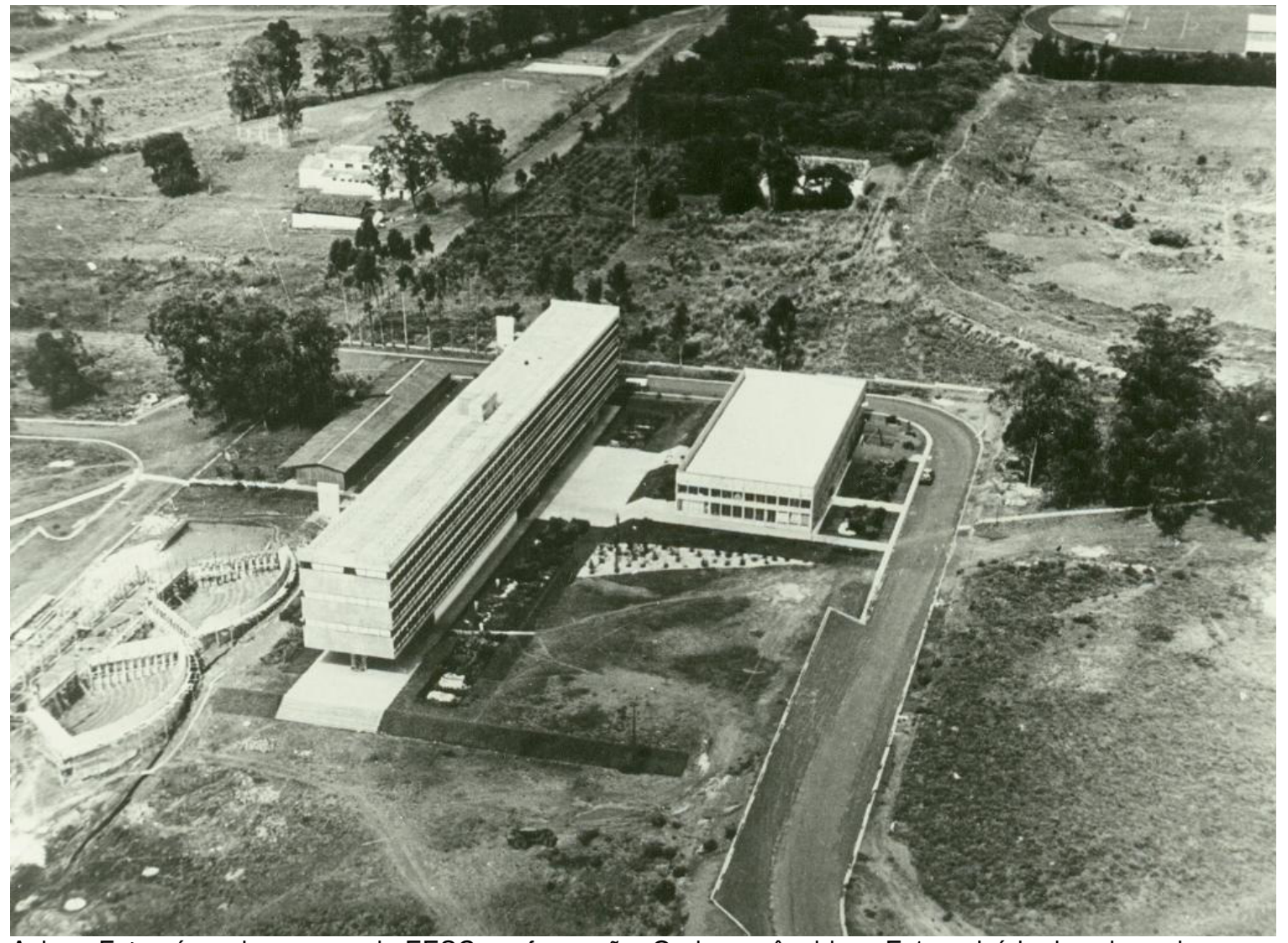

Acima: Foto aérea do campus da EESC em formação. Onde se vê o bloco E-1 e o início das obras dos anfiteatros e os acessos externos. Fonte:Fundação Pró-Memória de São Carlos. Abaixo: construção dos Anfiteatros em fase mais avançada, já com as floreiras e escadas externas em execução. 1961. Fonte: Nosella (2000)

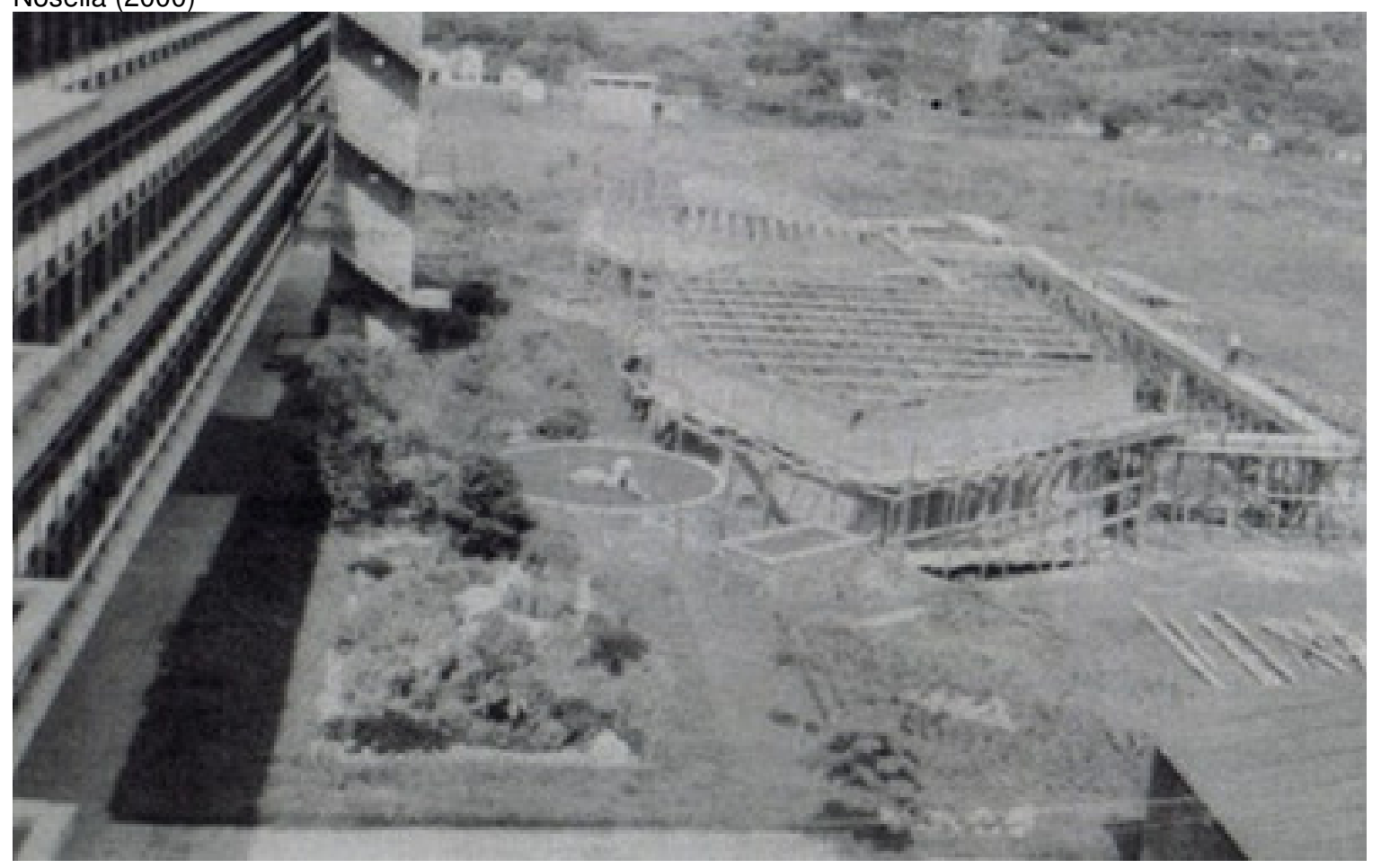




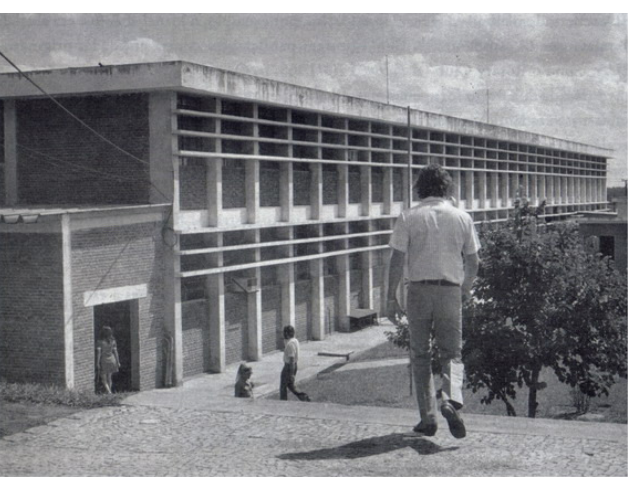

Instituto de Quimica e Fisica. 1973

Acima: Instituto de Física da EESCem 1973. Projeto de Luiz Gastão de Castro Lima.Fonte: Nosella e Buffa (2000) Abaixo: EESC. Floreira e escada em pedra projetadas por Luiz Gastão. O E-1 ao fundo e parte do beiral de um dos anfiteatros à frente. Fonte: EESC-Escola de Engenharia de São Carlos. Encarte. Publicação interna. 1974. Acervo do arquiteto. LIEP-UFSCar

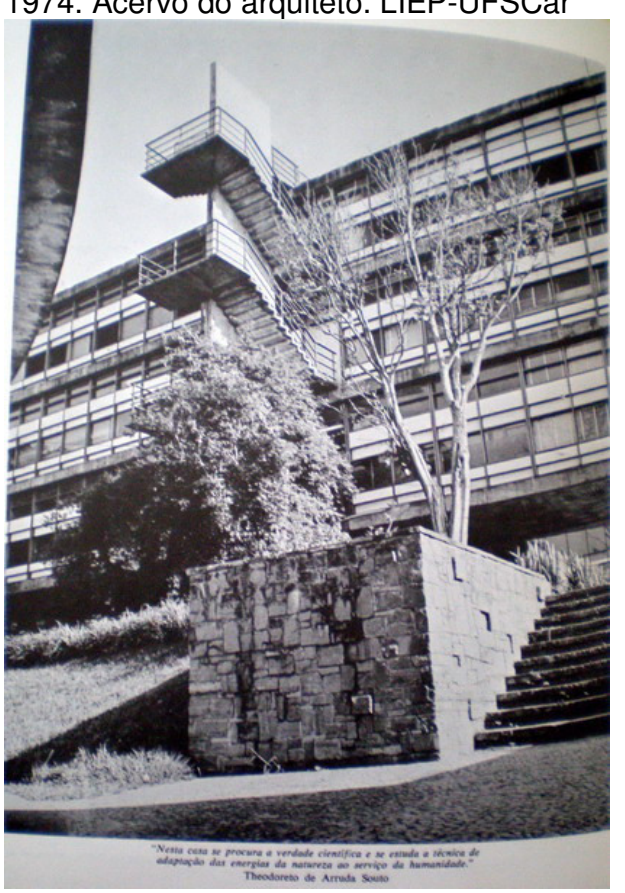

Enquanto arquiteto da Escola de Engenharia, Gastão projetou não apenas os edifícios, mas elaborou projetos paisagísticos e definiu todos os acessos e caminhos.

Destes, muitos foram alterados em função das novas edificações que se sucederam, mas alguns em especial permanecem preservados, a exemplo da área externa dos anfiteatros. Estes projetos revelam uma preocupação constante com a topografia original, buscando vencer o desnível por meio de floreiras revestidas em pedra e degraus ergonomicamente calculados: "O Gastão nunca fez nem deixou que se fizesse degraus com espelho superior a $17,5 \mathrm{~cm}$ " ${ }^{17}$ Essa foi uma preocupação constante em seus projetos, possivelmente advindos da observação da experiência mal sucedida do E-1.

Não apenas os edifícios, mas também as áreas externas projetadas por Gastão trazem referências da arquitetura wrightiana, na exploração não só da textura do material, mas na forma de assentamento dos blocos, num jogo de saliências e reentrâncias.

Sua preocupação ia muito além do aspecto plástico. Denotava um profundo conhecimento e atenção aos aspectos construtivos, na assimilação de conceitos de conforto ambiental, na viabilidade financeira, na proporção do passo. O cálculo preciso é presente em cada detalhe e revelado a partir do uso do espaço, desde o dimensionamento correto dos percursos que ritma um passo confortável até o escoamento das águas pluviais, no caimento correto e imperceptível dos planos horizontais ao nível do solo. Aqui abrimos uma exceção

\footnotetext{
${ }^{17}$ Antonio Periotto em conversa informal com a autora. Periotto conviveu muitos anos com Luiz Gastão e foi desenhista em seu escritório, colaborando com diversas obras, dentre elas, a sede social do São Carlos Clube.
} 
para a escada externa dos anfiteatros da EESC, onde o arquiteto assume na parte externa, a continuação da lâminas internas do auditório.

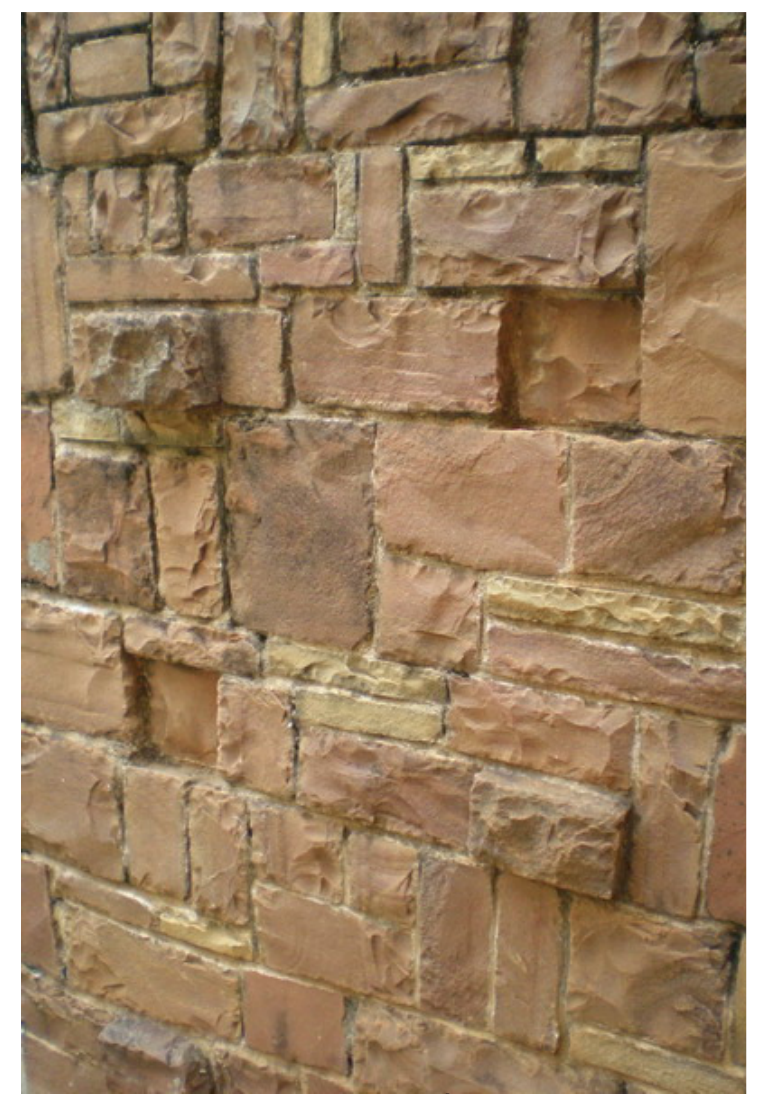

Detalhe da floreira em pedra. Área externa aos anfiteatros da EESC.Fonte: foto da autora
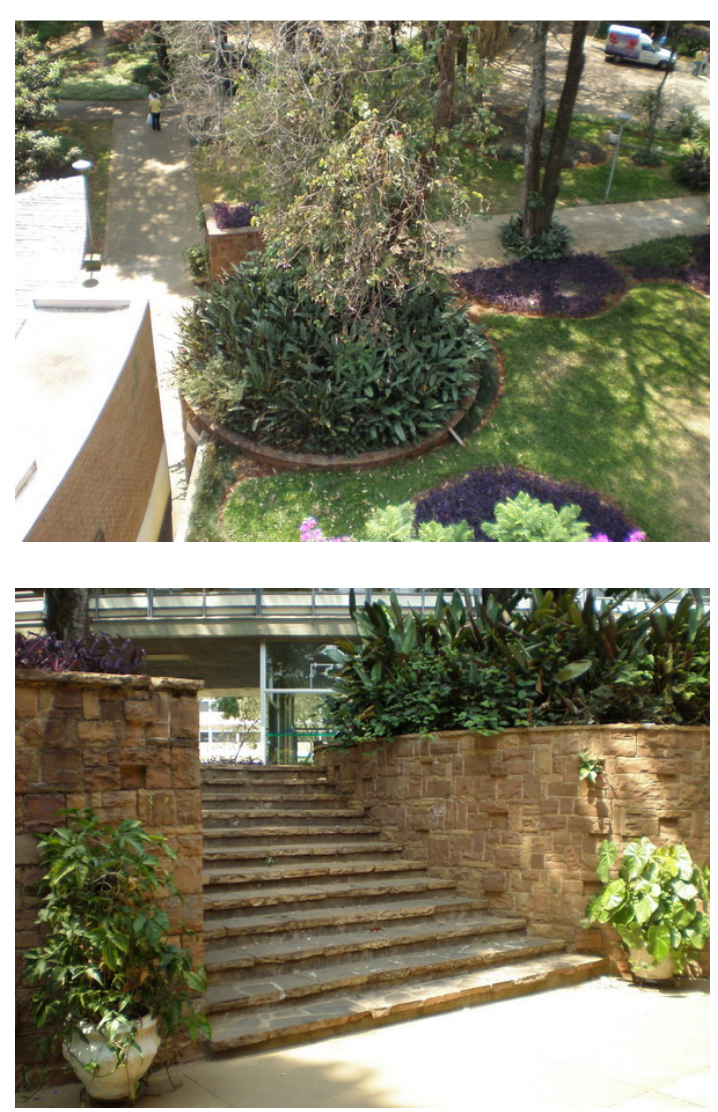

Paisagismo anfiteatros da EESC. Luiz Gastão de Castro Lima. Fonte: fotos da autora 
Os anfiteatros

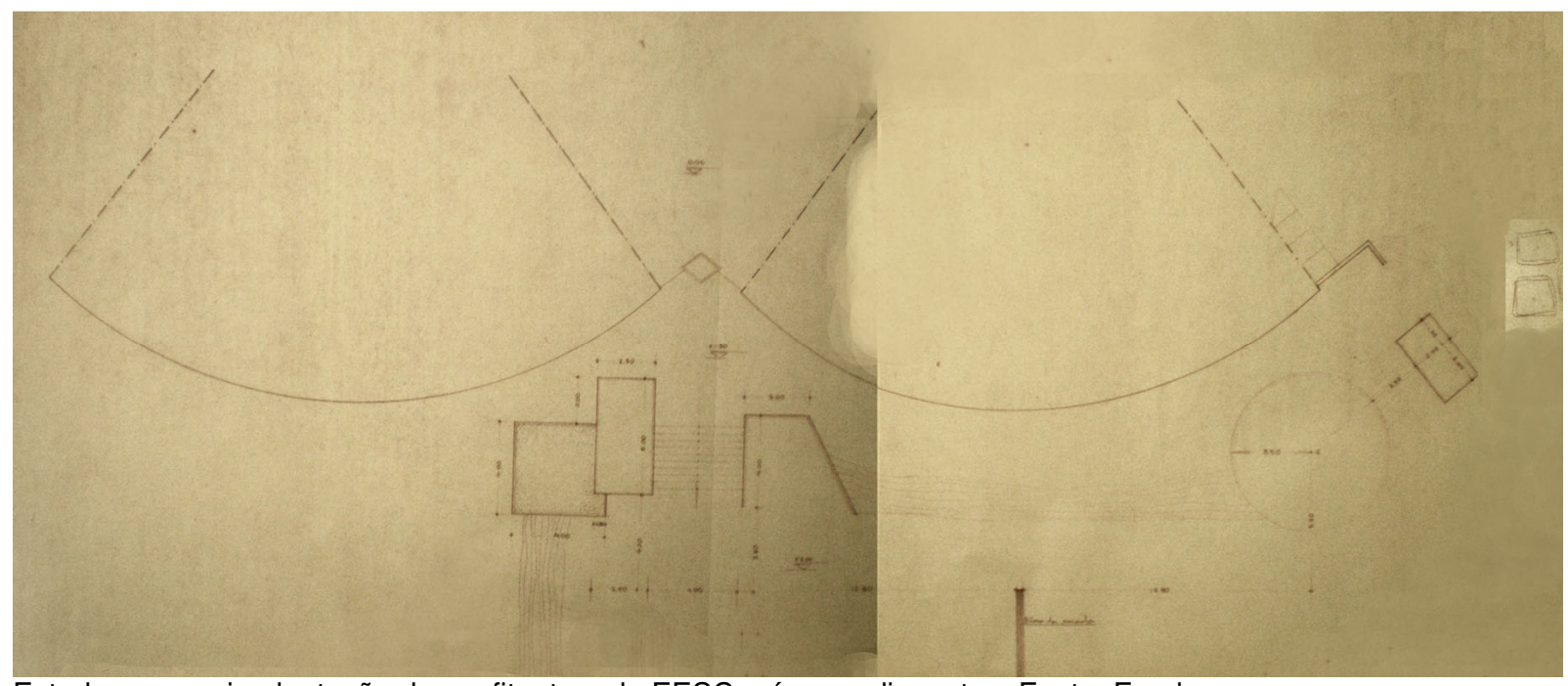

Estudos para a implantação dos anfiteatros da EESC e áreas adjacentes. Fonte: Fundusp

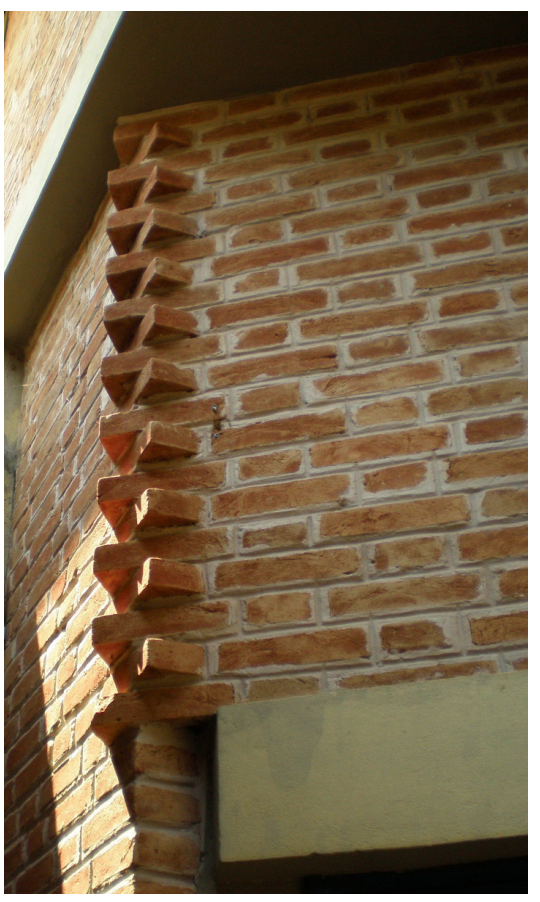

O conjunto dos anfiteatros e salas de apoio foi um dos primeiros trabalhos de Luiz Gastão junto ao Fundo de Construção da Universidade de São Paulo (Fundusp). O projeto prevê dois volumes interligados por um prisma longitudinal que deveria abrigar salas de aula e laboratórios. Atualmente servem à lanchonete, unidade de atendimento bancário e posto médico.

Inteiramente em tijolo à vista, as fachadas permitem composições inusitadas nos cantos vivos. Um delgado beiral circunda os dois volumes dos auditórios em todo seu perímetro, apoiado sobre uma platibanda que esconde a cobertura.
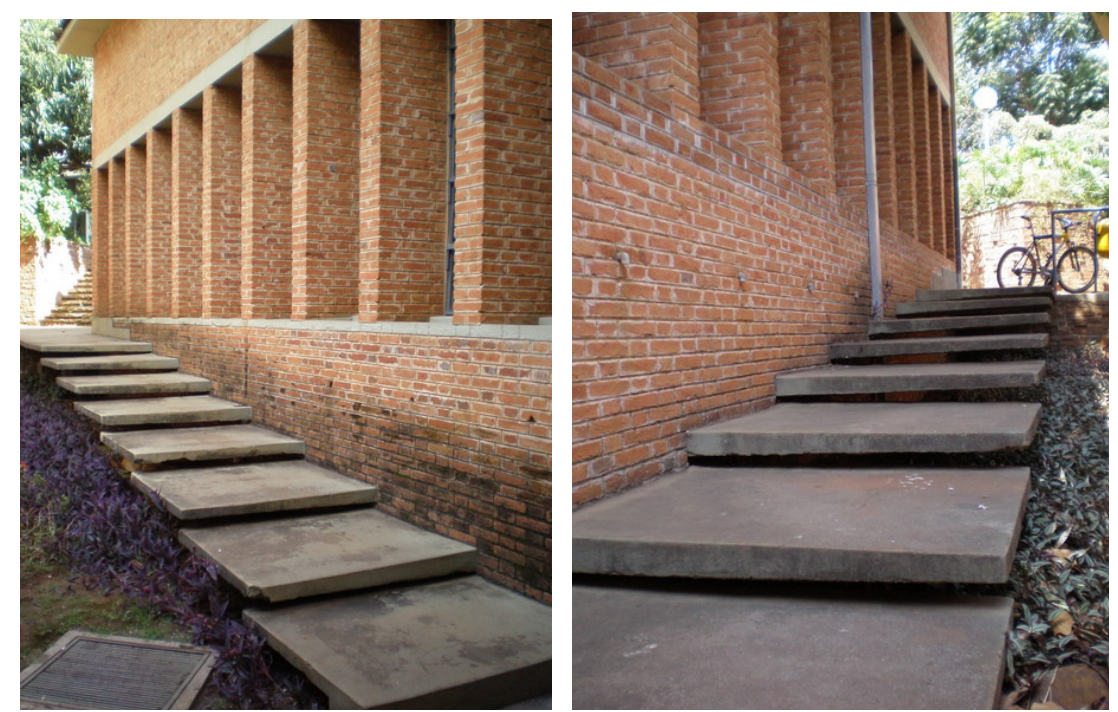

Anfiteatros EESC USP. Acima: detalhe da entrada. Ao lado: detalhes da escada lateral. Note na primeira foto, o auditório 1 com a altura original do peitoril e as floreiras. Na segunda foto, o auditório 2 (Jorge Caron) após reforma, com o peitoril já modificado. Fotos da autora 
Esta era originalmente em telhas de fibrocimento embutidas sob um pequeno beiral de concreto $e$ apoiadas sobre uma treliça de madeira. As telhas distanciadas do forro $1,75 \mathrm{~m}$ eram distribuídas em 12 águas de mínima inclinação com calhas intermediárias. O telhado, pensado de forma a elevar a platibanda 0 mínimo possível, deixava ver para quem o olhava de fora, nada além de um pequeno beiral em concreto. Intervenções posteriores descaracterizaram o edifício, a exemplo disso, a substituição grosseira da cobertura original por um telhado de cinco águas inclinadas que se sobrepuseram ao beiral.

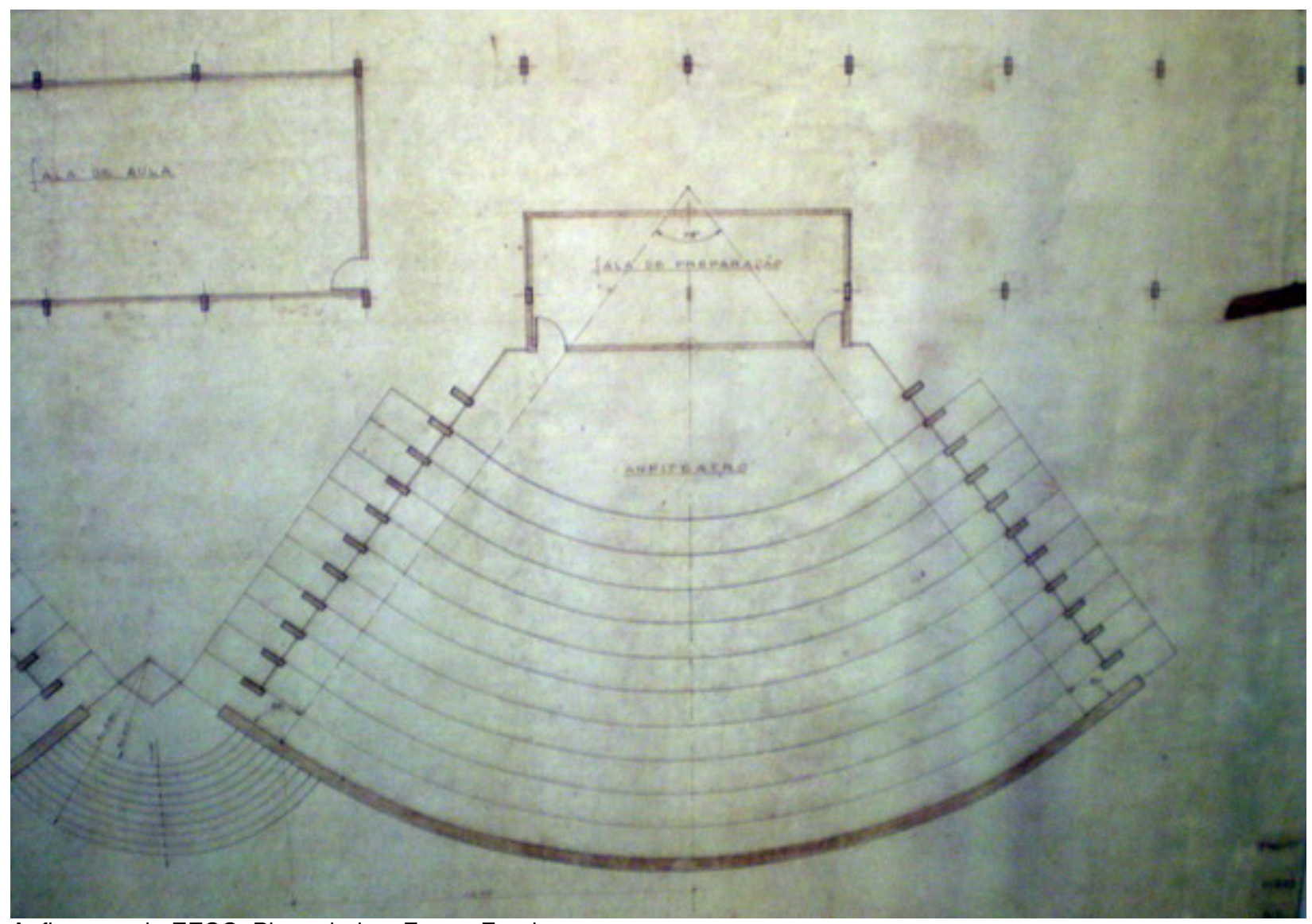




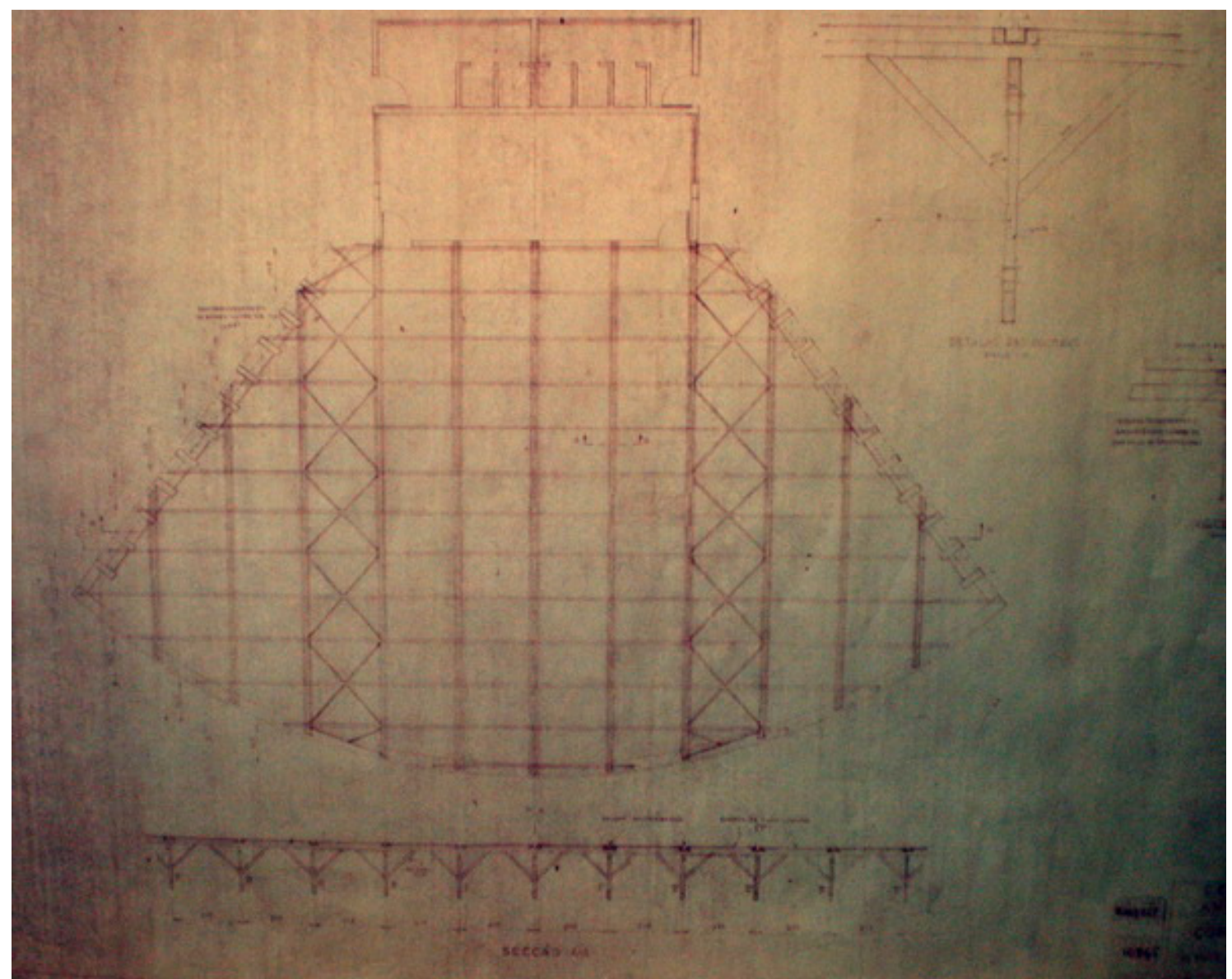

Anfiteatros da EESC. Planta de cobertura. Fonte: Fundusp

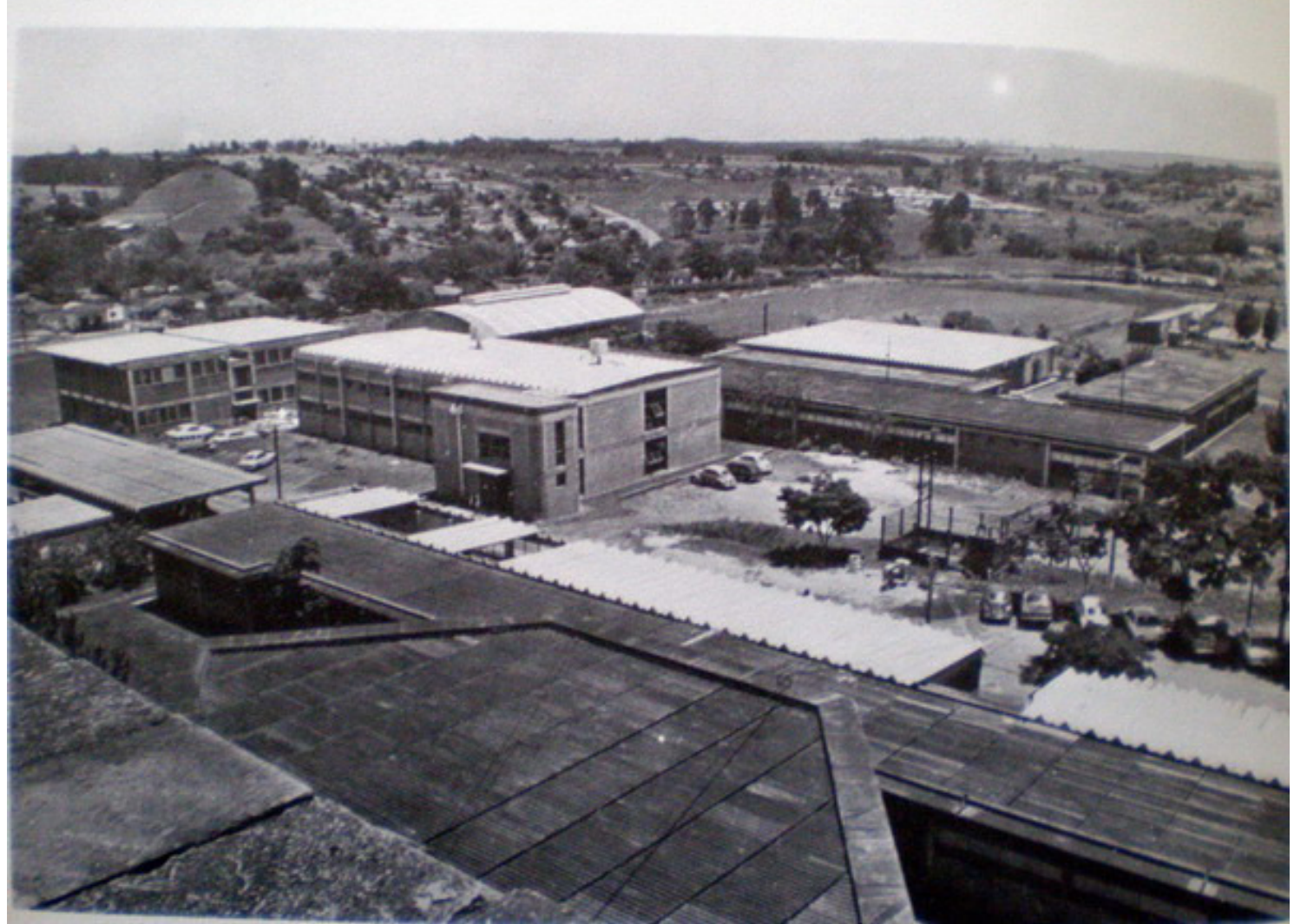

Vista da cobertura dos anfiteatros da EESC. Fonte EESC-USP Escola de Engenharia de São Carlos. Encarte. Publicação interna. 1974. Acervo do Arquiteto. LIEP-UFSCar 


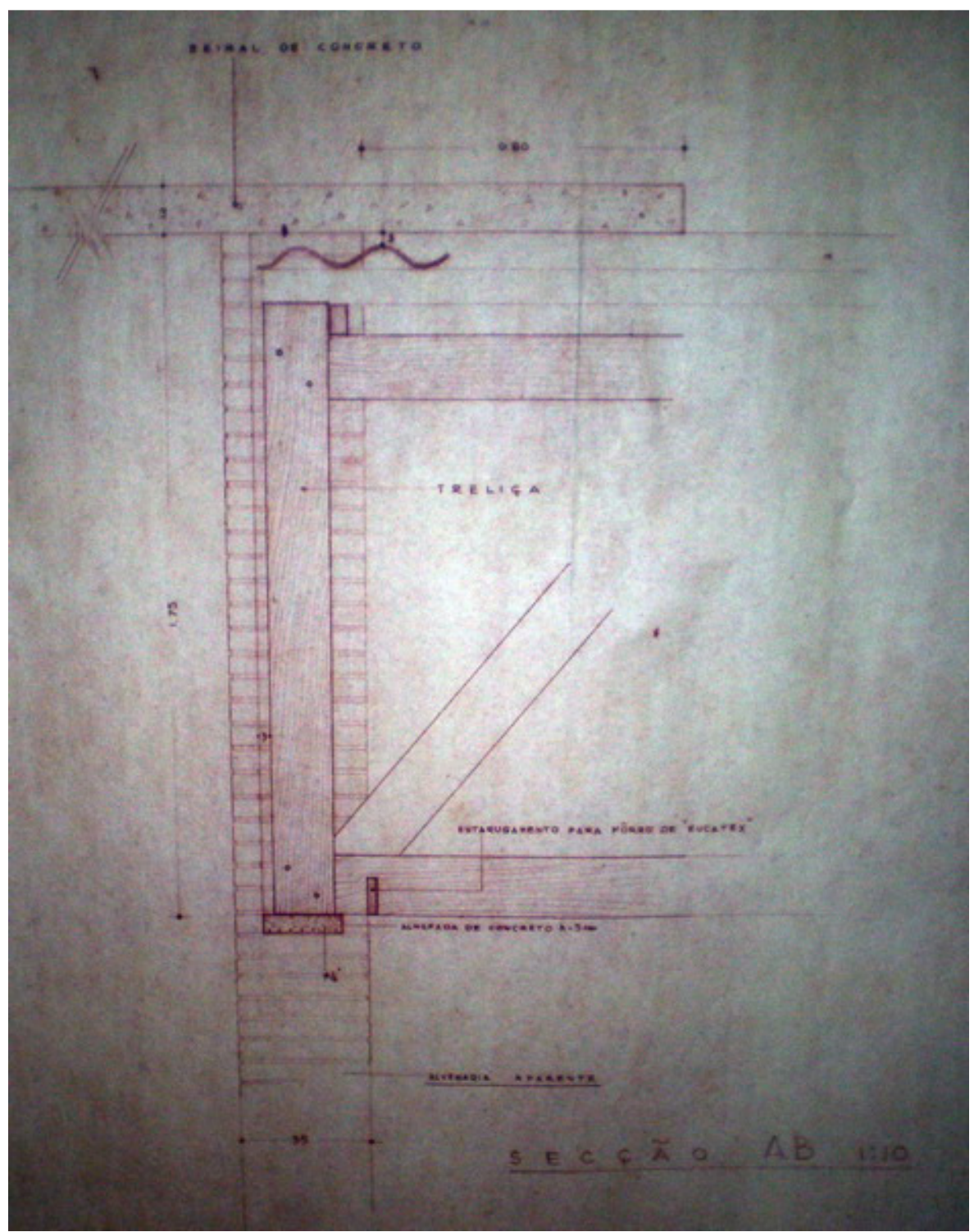

Anfiteatros da EESC. Acima: Detalhe da cobertura. Abaixo: detalhes dos caixilhos Fonte: Fundusp

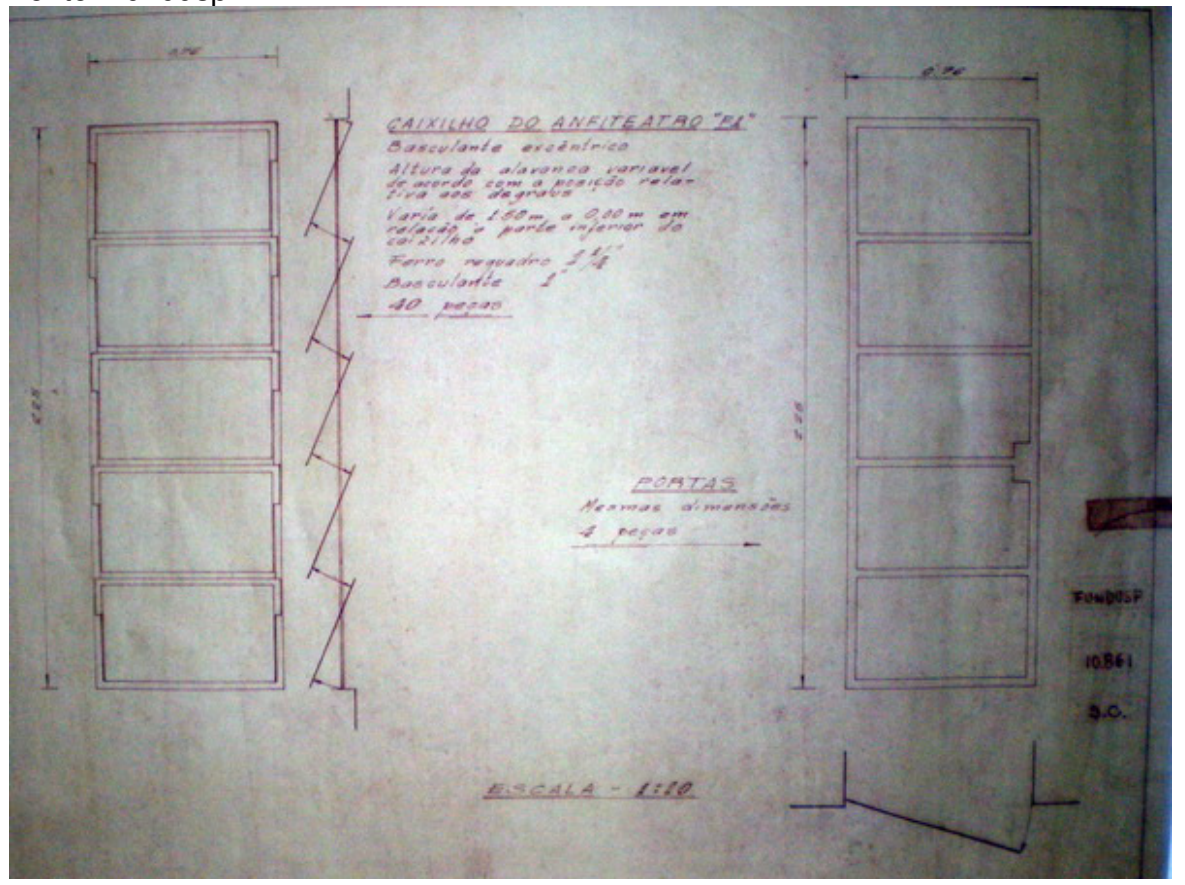


Nota-se no projeto dos anfiteatros, a seqüência estrutural revelada na fachada através da modulação de onze pilares em alvenaria de tijolos. As aberturas são resultantes dos nichos formados pelos pilares e estes permitem o surgimento de floreiras logo abaixo dos caixilhos.

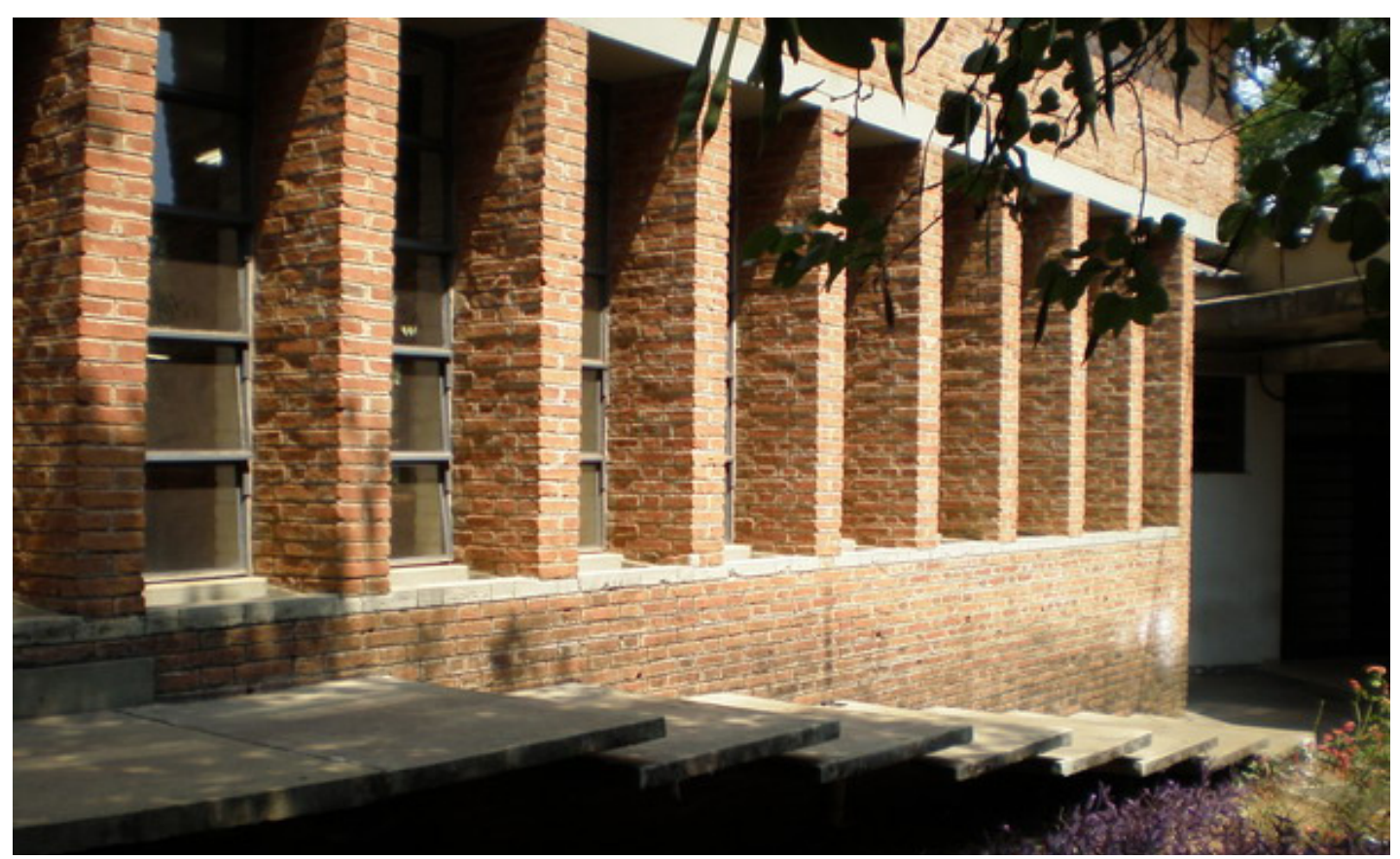

Vista lateral dos anfiteatros com as floreiras laterais. Foto da autora

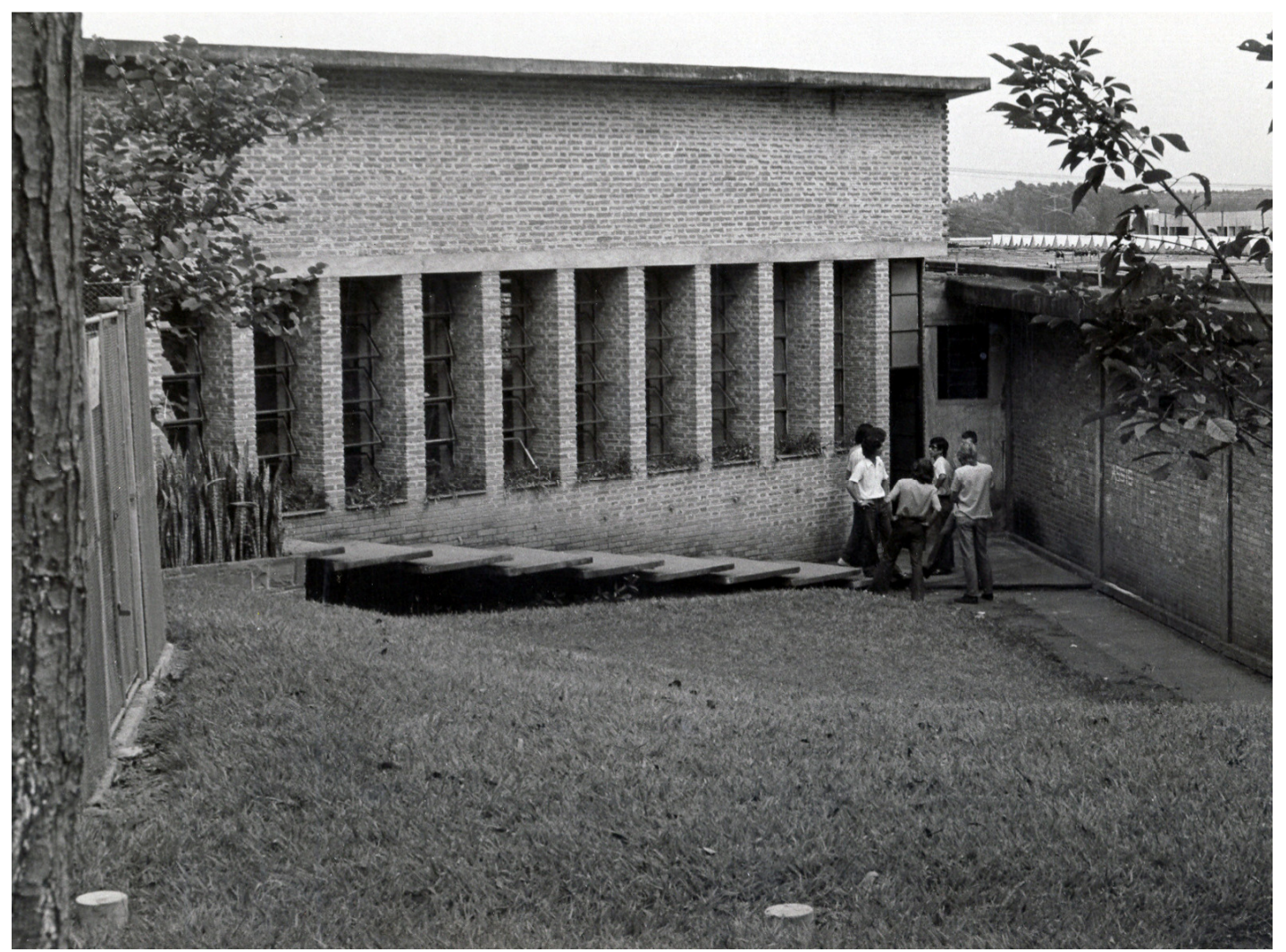

Anfiteatros da EESC na década de 70 onde ainda se vê o beiral em concreto .Fonte: Fundusp 


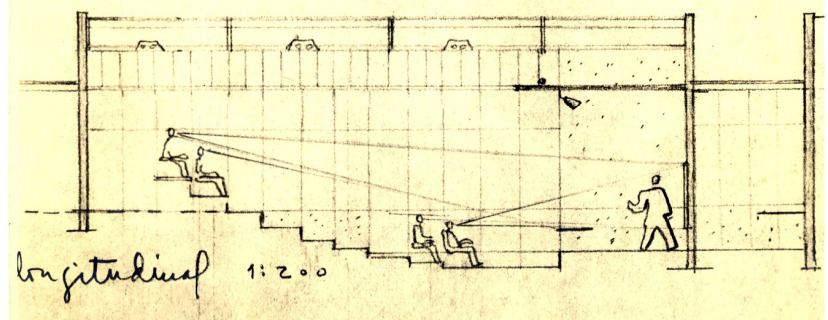

Acima: Estudos para os anfiteatros. Plano Diretor da EESC - 1957. Fonte Fundusp

Abaixo: detalhes da escada. Ao lado: vista interna auditório 1. Fotos da autora
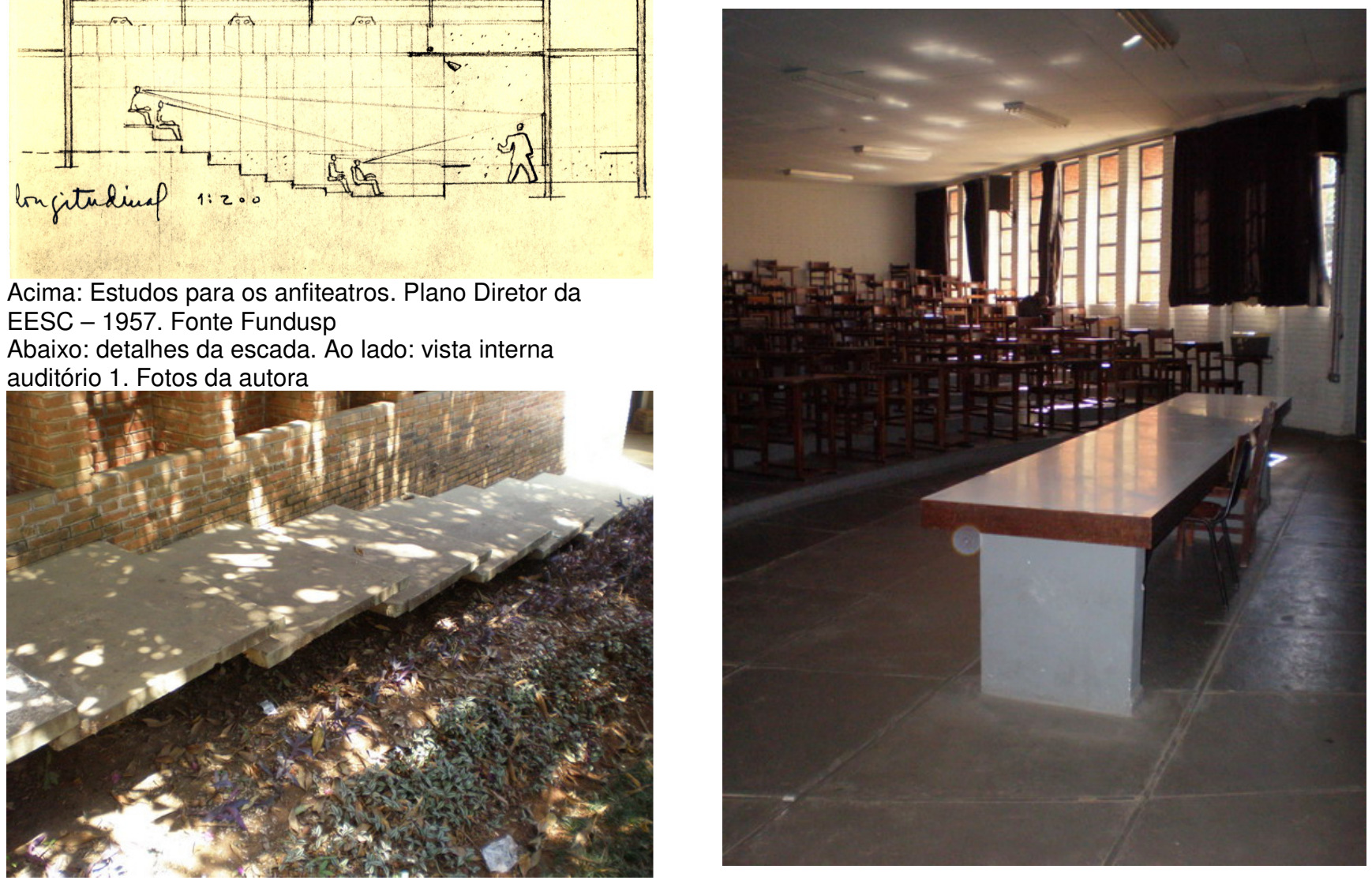

Luiz Gastão adota nesse projeto uma medida inusitada, onde o acesso se dá por meio de uma escada cujos degraus não foram pensados com base em conceitos de ergonomia, mas são tão somente a continuação dos pisos internos. $\mathrm{O}$ arquiteto se divertia ao ouvir as críticas à solução por ele adotada, pois a falta de proporção entre espelho e patamar confunde o caminhar. Gastão estava plenamente consciente, nesse projeto, que essa solução como medida estética, se sobrepunha aos conceitos de ergonomia. As lâminas dos degraus se afinam na extremidade dando sensação de leveza ao conjunto. Já nesse momento, Gastão participava ativamente dos cálculos estruturais de seus projetos e por intervenção dele, os degraus alcançaram o efeito desejado. 

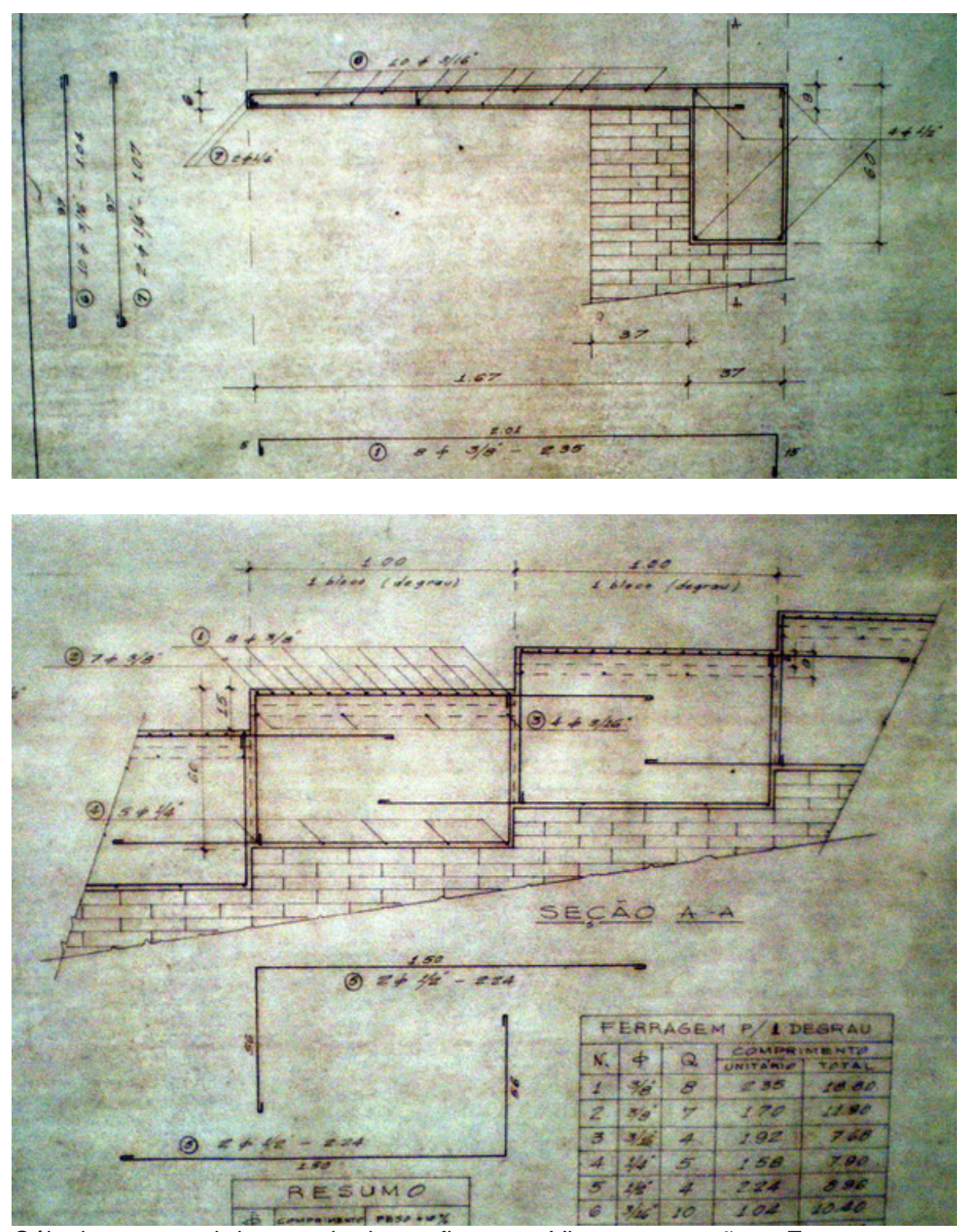

Cálculo estrutural da escada dos anfiteatros. Vigas e armações. Fonte: Fundusp

Em 1996, um dos auditórios dos anfiteatros foi reformado pelo arquiteto Jorge Caron e recebeu o seu nome. 

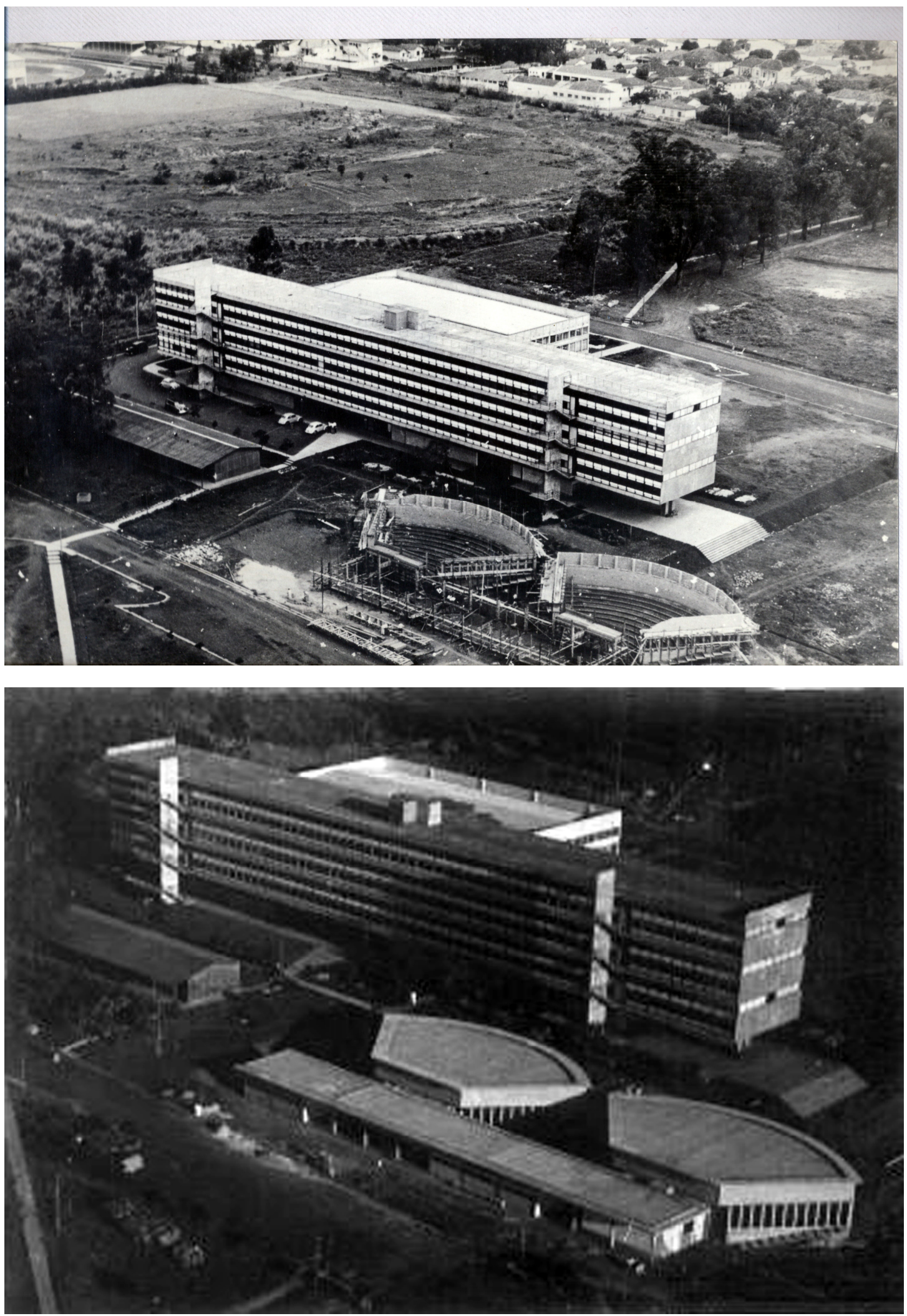

Acima: Anfitetros em Construção. Fonte: fundudp

Abaixo: Anfiteatros e salas de apoio com as obras concluídas. Fonte: acervo pessoal do arquiteto, LIEP-UFSCar 


\section{Habitação para estudantes}

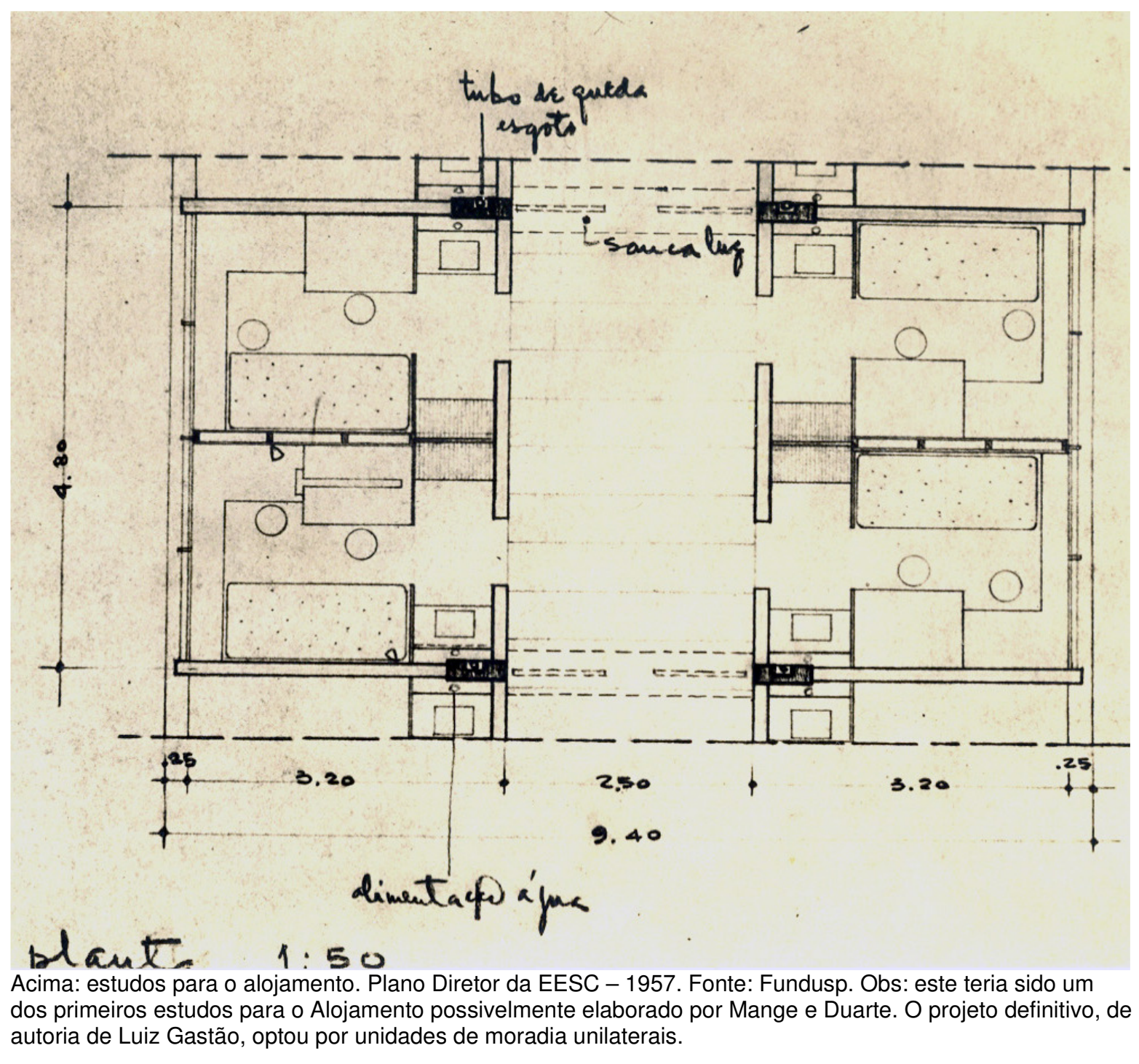

Além dos anfiteatros, um dos primeiros trabalhos desenvolvidos por Luiz Gastão frente ao Plano de Ação foi o primeiro edifício destinado à habitação dos alunos.

Os dois projetos foram elaborados pelo arquiteto a partir dos estudos feitos por Mange e Hélio Duarte, no primeiro planejamento para o campus em 1957. A implantação dos blocos prevista inicialmente foi respeitada no projeto posterior. Nota-se a racionalidade da planta proposta para o alojamento no estudo inicial, mantida em parte pelo projeto definitivo desenvolvido por Gastão quatro anos mais tarde. 


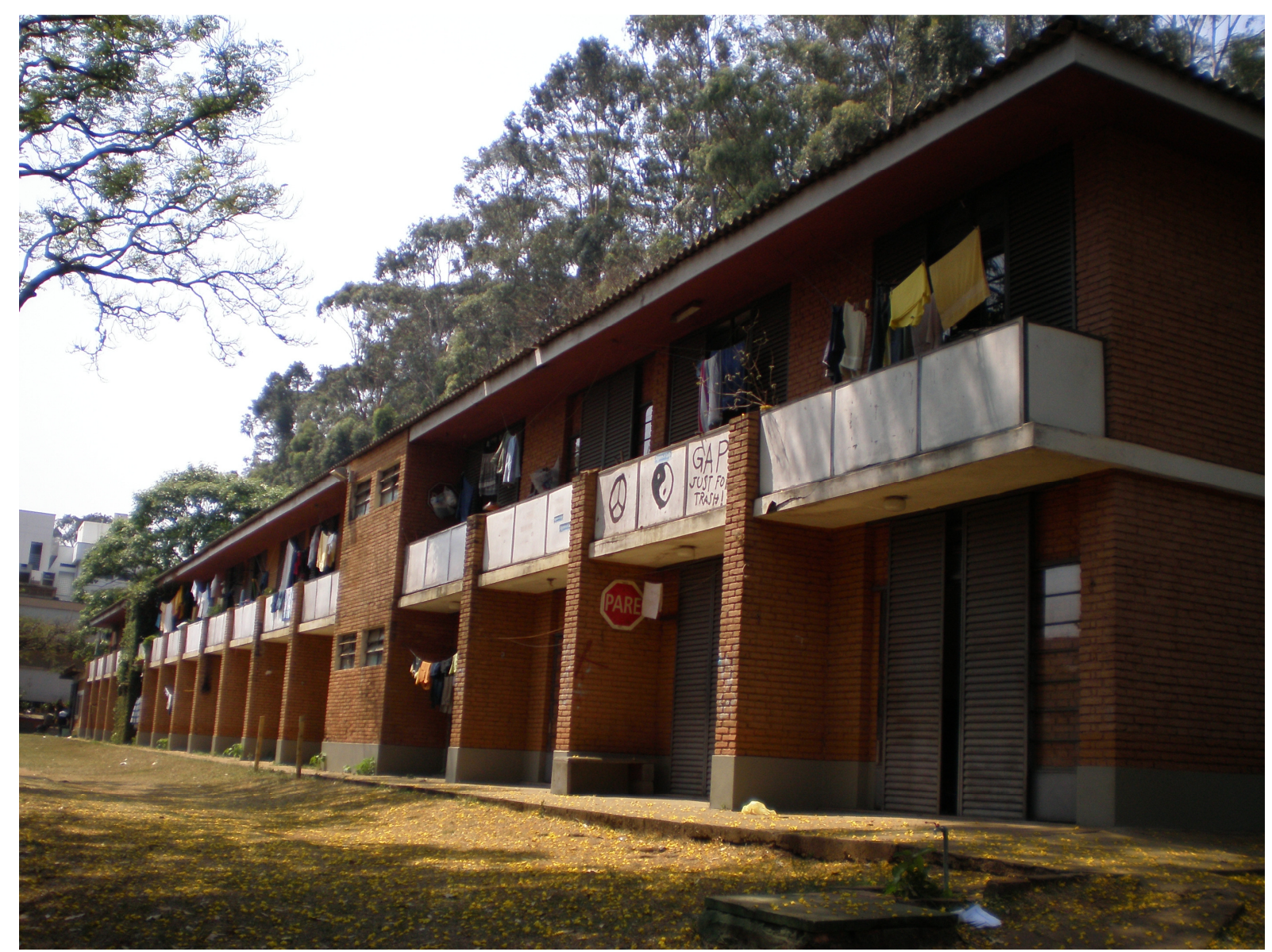

Alojamento estudantil. Fonte: fotos da autora
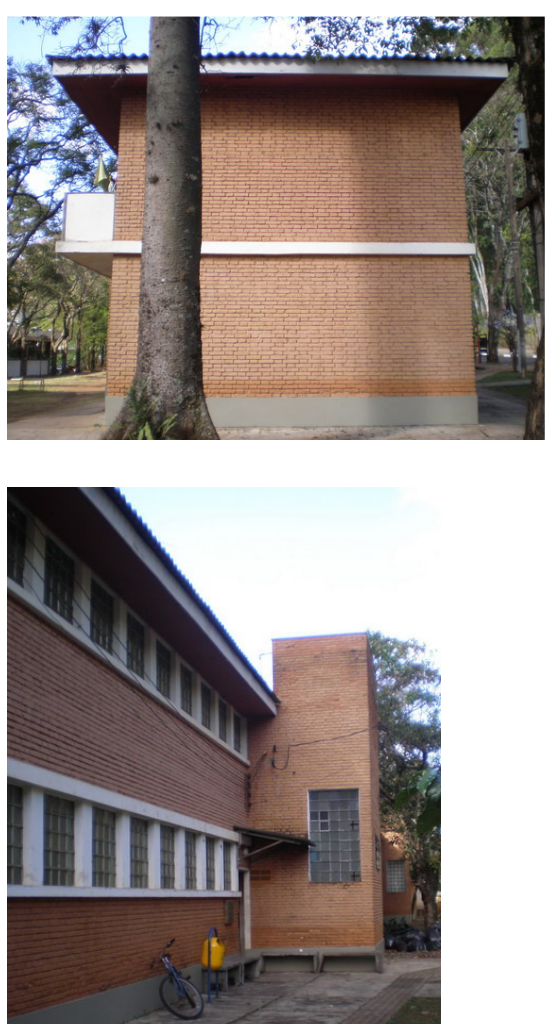

A continuidade dos caixilhos idealizada no primeiro estudo a exemplo do pan de verre do $\mathrm{E}-1$, deu lugar a uma modulação marcada pela alvenaria em tijolo aparente de espessura generosa (1 tijolo e meio) que modula as aberturas dos dormitórios. A experiência dos caixilhos contínuos do E-1 já havia provado a inviabilidade de sua aplicação.

O recurso de 1 tijolo e meio se repetirá em obras posteriores, inclusive na igreja Nossa Senhora de Fátima (1968) onde Gastão se remete ao edifício como algo "preso à terra".

As áreas hidro-sanitárias do alojamento foram concentradas junto à circulação vertical e optou-se por uma seqüência unilateral de dormitórios. Ao final da 


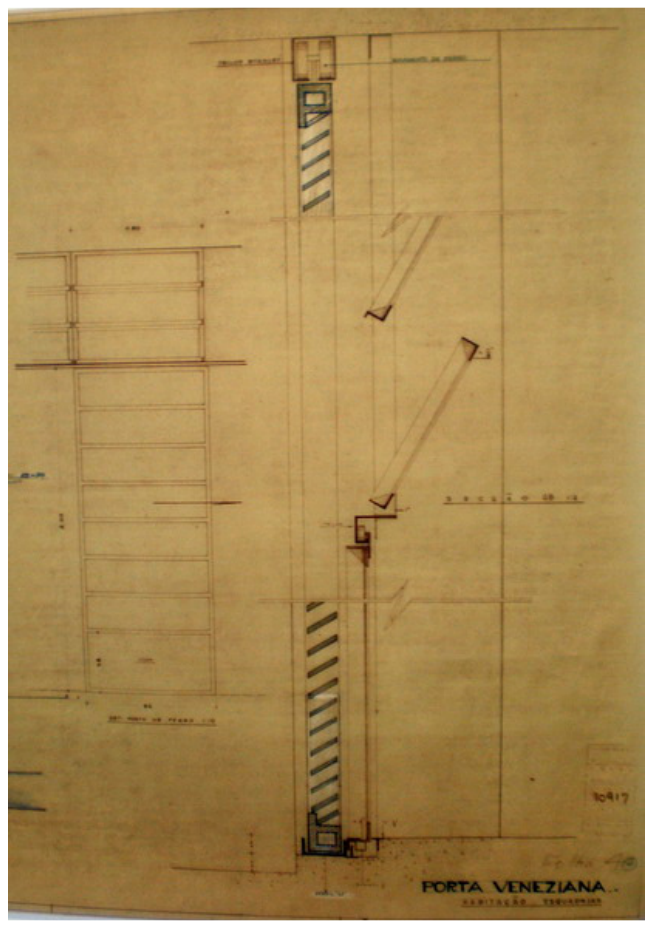

edificação foi reservada uma área comum de serviços não prevista no projeto inicial. As floreiras nascem sobre os apoios em alvenaria de tijolos e separam as sacadas de cada unidade habitacional.

Já nessa fase começam a se esboçar características peculiares do arquiteto recorrentes em obras posteriores: 0 uso do tijolo à vista, a horizontalidade do conjunto e a presença de uma "linha" densa, fortemente marcante na fachada, seccionando os dois pavimentos superior e térreo, por vezes em concreto aparente, por vezes branca, de forma a contrastar com o tom terra do tijolo cerâmico.

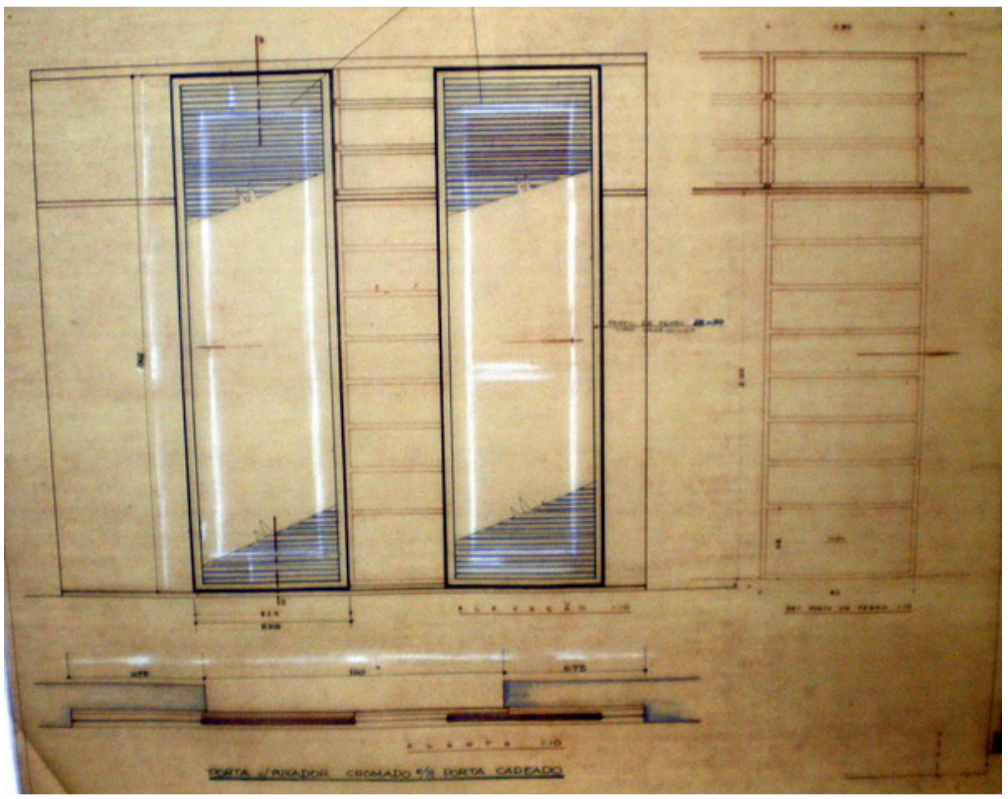

Abaixo: planta e elevação do alojamento estudantil. Acima: detalhe de caixilhos: porta veneziana. Fonte: Fundusp

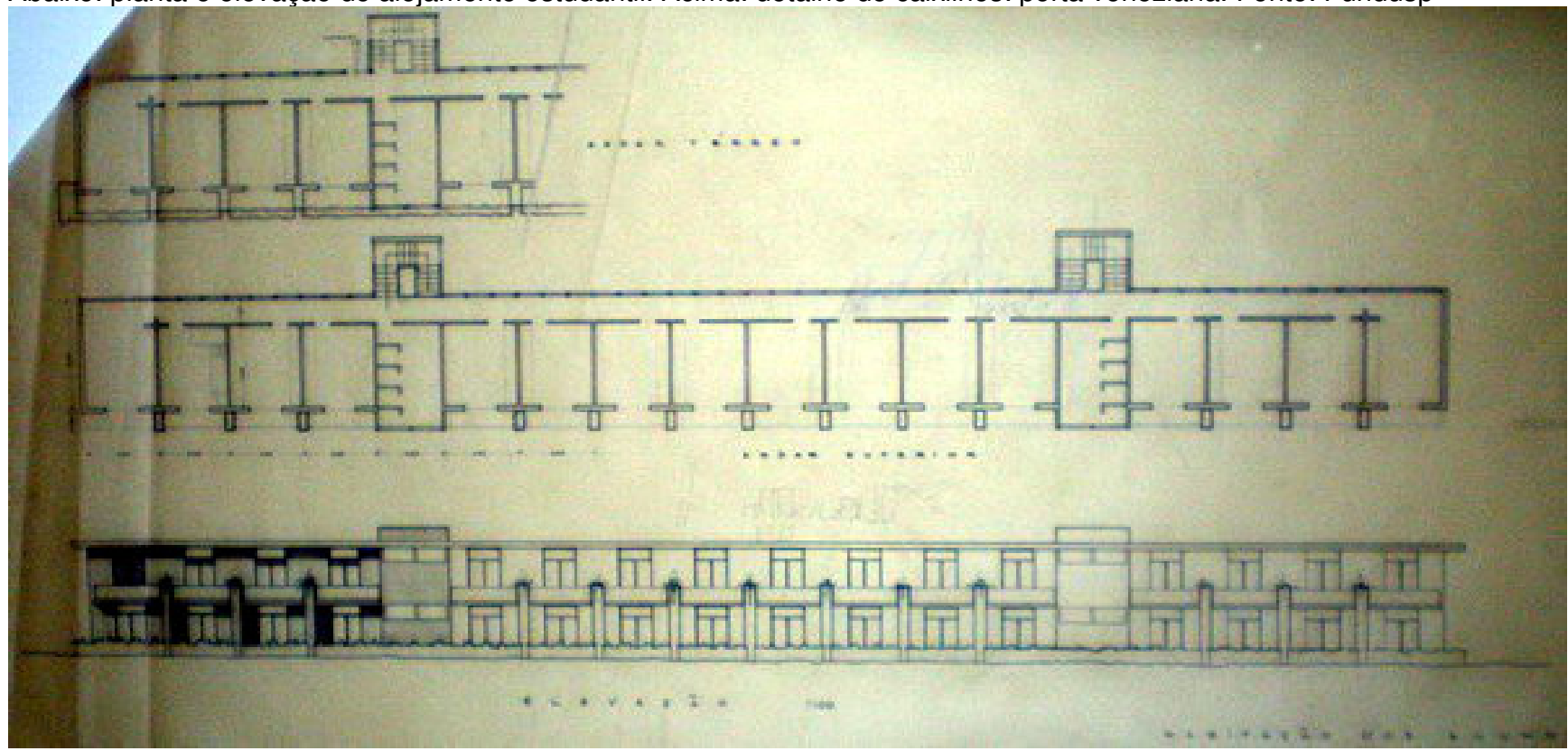




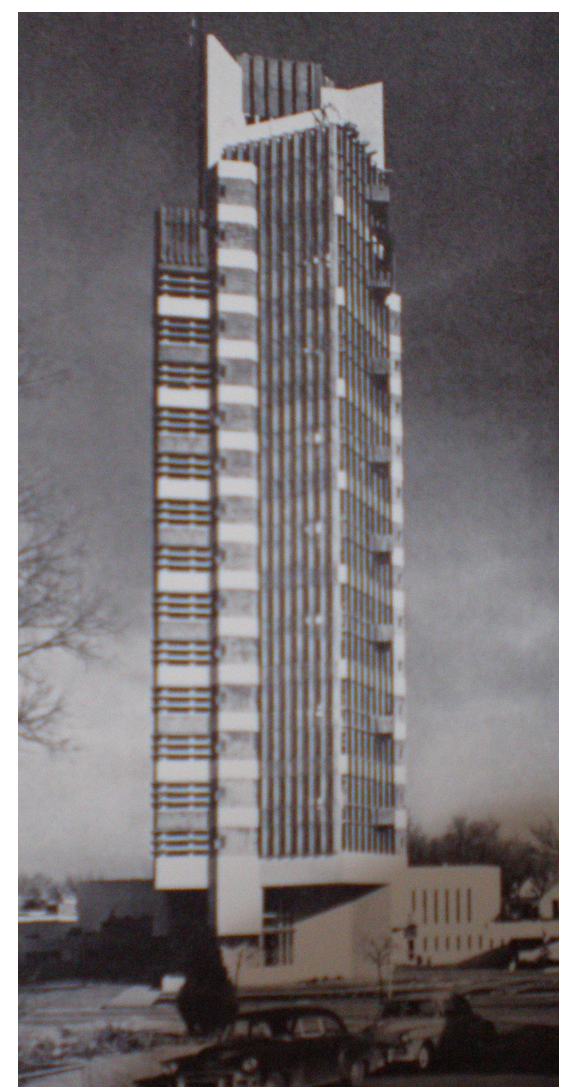

H. C. Price Fonte: PFEIFFER (2000) pg 165

\section{Outros exercícios projetuais}

Os primeiros projetos de Luiz Gastão realizados em São Paulo também datam de 1961: uma residência em Moema na Rua Curitiba 171, hoje demolida e o laboratório Fleury da Rua Cincinato Braga.

Implantado numa área de $1200 \mathrm{~m}^{2}$ no bairro do Paraíso, a primeira unidade própria do Laboratório previa para um prédio de dois andares, uma ampla sala de espera e várias salas de coleta.

O prédio traz influências wrightianas, em parte presentes nos brises horizontais da fachada que já haviam sido usados por Wright na torre para a Harold C. Price Company, projeto de 1952 concluído em 56. A fachada do laboratório Fleury parece transplantar os brises da fachada norte do H. C. Price Tower para o prédio do centro médico.

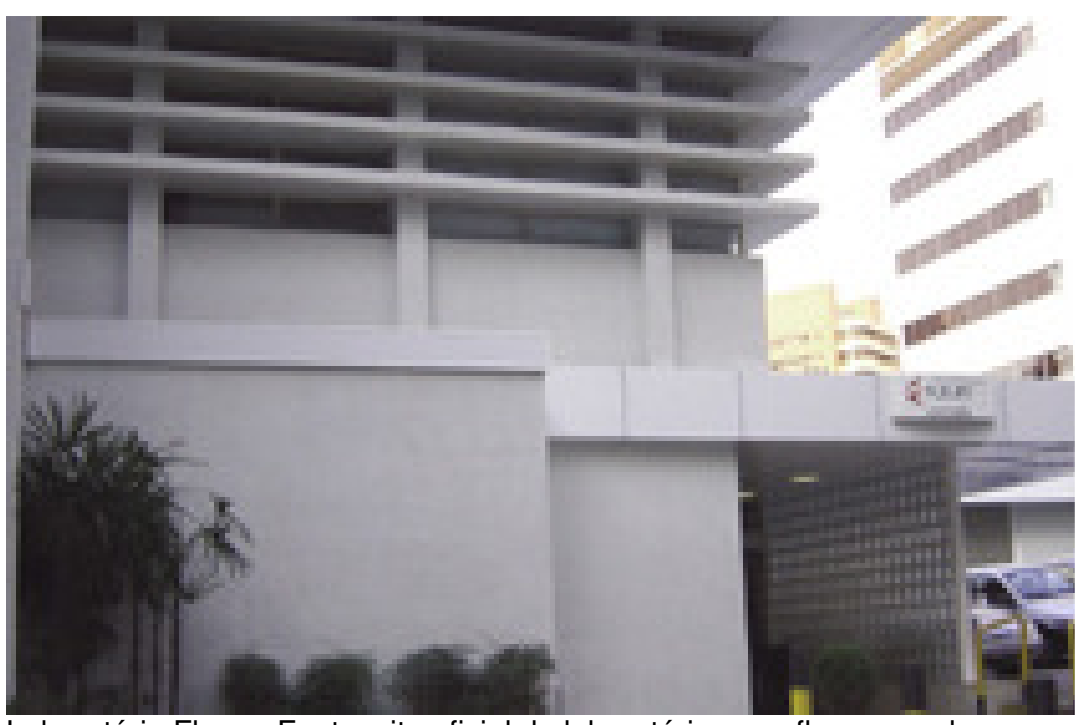

Laboratório Fleury. Fonte: site oficial do laboratório www.fleury.com.br

Infelizmente, durante essa pesquisa, o laboratório se negou a fornecer as plantas e proibiu qualquer tipo de registro fotográfico ou acesso ao interior do edifício para fins de documentação. Acreditamos que um estudo mais apurado nos revelaria aspectos interessantes de sua 

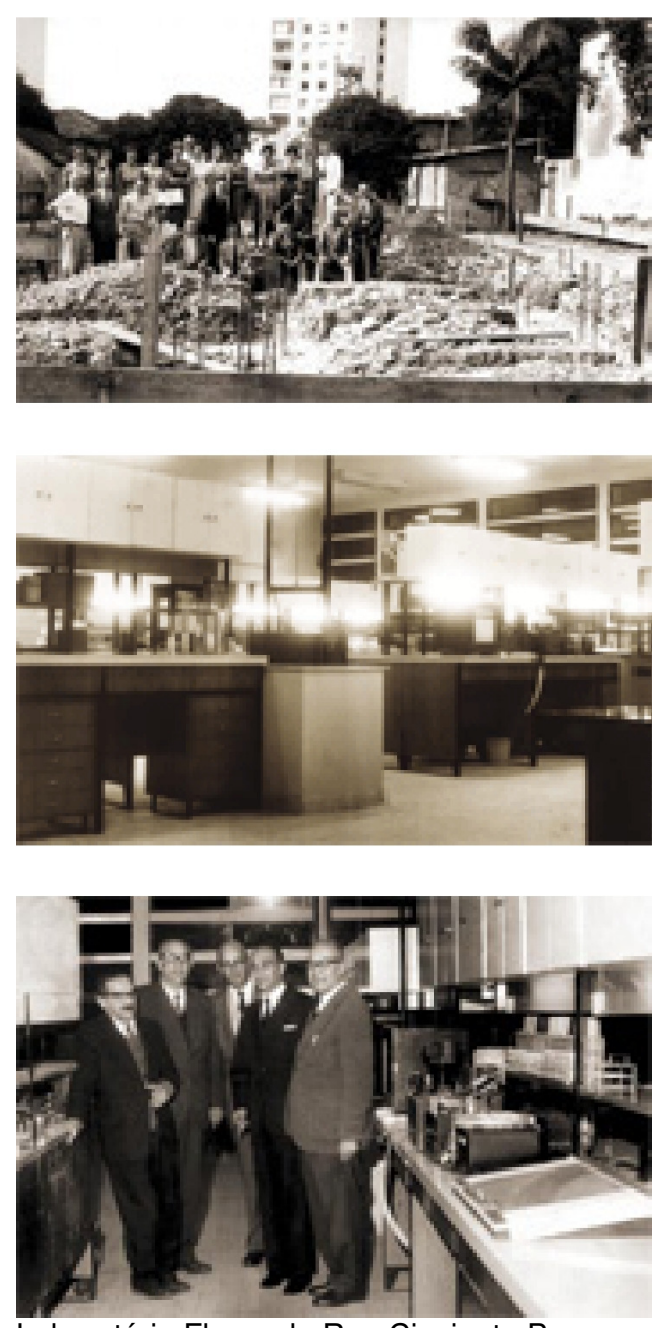

Laboratório Fleury da Rua Cincinato Braga. Acima: início das obras em 1961. No meio e abaixo: instalações do laboratório em 1962. Fonte: www.fleury.com.br arquitetura que, esperamos, possam ser investigados em ocasião futura.

Ainda à frente do Plano de Ação, Luiz Gastão realiza o projeto para o Restaurante e Centro Social da EESC e faz a reforma do Centro de Processamento de dados. A luz difusa advém da fenestração das aberturas junto à laje de cobertura. Característica fortemente presente na arquitetura orgânica de Wright, que alcança aqui uma leveza expressiva, parecendo a laje flutuar por não tocar a alvenaria.

Com o fim do mandato de Carvalho Pinto em 1963, Gastão deixa o cargo de arquiteto do campus e ingressa na EESC como professor junto ao Departamento de Estruturas e Arquitetura, sem romper o vínculo com a FAU. ${ }^{18}$

No mesmo ano, profere a palestra "Raízes da Arte Contemporânea" no Instituto Álvaro Guião em São Carlos e no ano seguinte, a palestra "A iluminura Medieval" na Escola de Biblioteconomia e Documentação de São Carlos. A sua atração pela representação gráfica e pelo desenho artístico e técnico começa a se tornar mais intensa a partir de então.

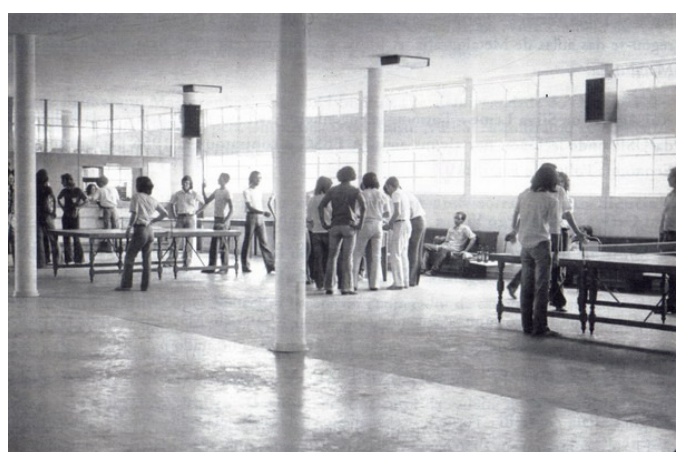

Centro Social. EESC em 1972. Fonte: Nosella (2000) p. 53

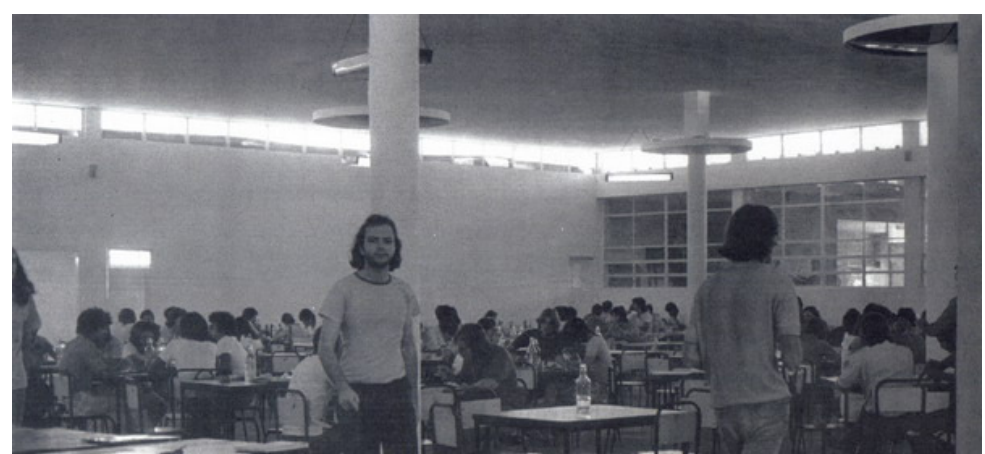

Restaurante EESC em 1972. Fonte: Nosella (2000) p. 53

\footnotetext{
${ }^{18}$ Luiz Gastão terá dois momentos como docente na EESC. O primeiro, de 1964 até o final de 1968 , quando deixa São Carlos e vai para Brasília. O segundo momento inicia após sua passagem pela UNB, voltando à Instituição em 1973 onde ficaria até 1986.
} 


\section{Abrindo caminhos}

Nesse momento Gastão dá continuidade ao trabalho de projeto com escritório próprio. Durante muitos anos atuou como único profissional de arquitetura em São Carlos. Essa hegemonia alcançada pelo fato de ser único, não resultou, todavia numa facilidade prática de atuação.

Todo aquele arrojo da arquitetura racionalista que caracterizou o crescimento metropolitano dos grandes centros - São Paulo e Rio - no interior não encontrava uma receptividade muito grande. (...) Então, o que se podia fazer não era a arquitetura desejada, mas a arquitetura possível.

Durante toda a década de 60 arquitetos formados em São Paulo e no Rio de Janeiro, migraram para o interior, difundindo através de sua atuação, ares de uma modernidade.

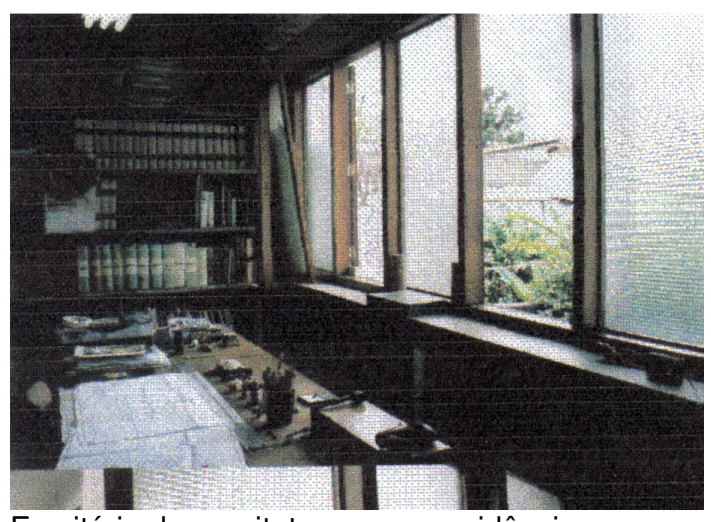

Escritório do arquiteto em sua residência em São Carlos. Fonte: Fundação Pró-Memória de São Carlos
O Gastão era umas das figuras, daqueles arquitetos pioneiros que se mandavam pro interior. Tinha um bom grupo deles, cada cidade acabava tendo um arquiteto que "pioneirava". (...) que deixavam de viver a vida como se dizia na época "na boa" e ficavam batendo em ponta de faca no interior. ${ }^{19}$

O campo árido a que Caron se refere fez materializar pelas mãos dos pioneiros uma obra até certo ponto mais modesta, mas digna de toda atenção. Uma arquitetura pensada no limite de uma época e de um contexto que estava ainda longe do discurso modernista presente na metrópole, nas realizações de Pampulha ou

\footnotetext{
${ }^{19}$ Jorge Caron In LIMA, Luiz Gastão de Castro. Aula Prof. Gastão e Prof. Caron. EESC-USP. Aula gravada em vídeo-tape. CEDOC. EESC-USP. 199?. (anexo 2: entrevistas e depoimentos)
} 
Brasília, nem tão pouco se valia da escala e das possibilidades técnicas disponíveis nos grandes centros.

A experiência mostrou-me então a necessidade de enfrentar um trabalho executado através de materiais convencionais como, por exemplo, o tijolo e a telha de barro - mais coerentes como elementos disponíveis para construção na maior parte do Brasil - contando com mão de obra a eles habituada, dispensando do processo pormenores construtivos mais elaborados, seja pela dificuldade de interpretação dos desenhos, seja pela inexistência de mão de obra mais especializada. ${ }^{20}$

Dessa forma, Gastão foi gradativamente abrindo um caminho ainda virgem e revelando as "multi-facetas" de atuação do arquiteto.

Eu senti que havia uma realidade a ser enfrentada, onde não entravam o concreto, o blindex ou a discussão do racionalismo europeu. Ninguém sabia o que era isso, a música concreta e toda essa preocupação que nós temos de procurar construir o futuro em fortes alicerces, na coerência do processo histórico, esquecendo que existe uma realidade do presente que não está tão fortemente ligada a essa nossa coerência com o processo histórico. Evidentemente, essa realidade ainda poderá ser aceita.

Enfim, encarar uma realidade profissional para abrir caminho efetivo para uma participação da arquitetura em todas as comunidades, onde as características metropolitanas só se faziam sentir na influência cada vez mais avassaladora das mensagens da sociedade de consumo. $(\ldots)^{21}$

Em 1964, Luiz Gastão ingressa no mercado dos projetos industriais. Este momento é caracterizado por

\footnotetext{
${ }^{20}$ Luiz Gastão de Castro Lima em INSTITUTO DOS ARQUITETOS DO BRASIL - São Paulo.
} Arquitetura e desenvolvimento nacional: depoimentos de arquitetos paulistas. Pini, São Paulo, 1979. 
um intenso aprendizado e traz referências de sua experiência como docente da FAU, permitindo-o levar adiante as idéias colocadas pela reforma de 62. Datam deste período a primeira fábrica da Sanyo em Manaus e os trabalhos de Desenho Industrial junto à empresa Diamantul, que produzia ferramentas diamantadas para a indústria automobilística nacional. A passagem de Gastão pela Diamantul antecende e dá suporte à metodologia proposta anos mais tarde na montagem do curso de Engenharia de Produção da Universidade Federal de São Carlos.

${ }^{21}$ Idem, ibdem 
Em 1954, Roch Lionel Lavoie, técnico pioneiro em sondagem e perfuração do solo com ferramentas diamantadas no Brasil, funda a Prominas Ltda, empresa de São Carlos, especializada em sondagem e com oficina própria para a manutenção de seus equipamentos.

Uma das empresas para qual a Prominas prestava serviços, a The Cementation Company, se interessa pela fábrica-oficina de Lavoie e investe na aquisição de suas cotas, com o objetivo de transformá-la em uma indústria de perfuratrizes. O controle da Prominas passa então, a partir de 1957, para mãos inglesas.

Em 1960, em sociedade com a família Malta Campos, Lavoie assume o controle de uma fabricante de brocas de diamante destinada à sondagem e perfuração do solo, a Brocas Diamantul Ltda, que apesar de pequena, já tinha em seu capital uma área com mais de 70 mil $\mathrm{m}^{2}$ no bairro do Jardim Jockey Club, em São Carlos.

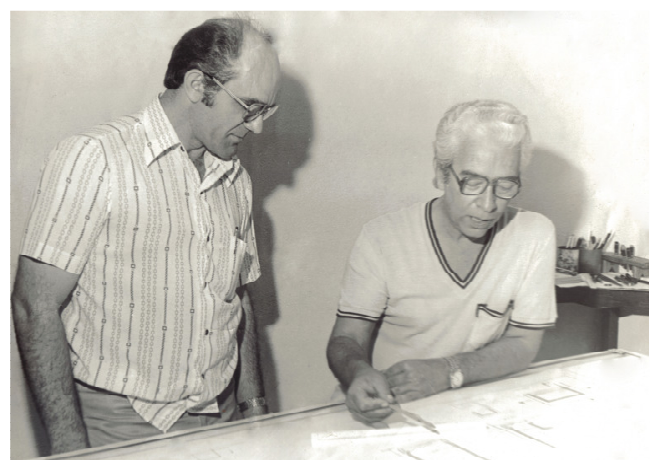

Antonio Periotto (desenhista e projetista que trabalhou por muitos anos com o arquiteto) e Luiz Gastão, em seu escritório.

Fonte:Foto fornecida por Antonio Periotto
Cerca de quatro anos depois, por meio de uma coparticipação acionária com a J. K. Smith, a Diamantul amplia seus limites. Nesse momento, Luiz Gastão é convidado a desenvolver o projeto de ferramentas para rebolos industriais junto à empresa. Na época, a indústria automobilística dava um salto importante no Brasil e a Diamantul era a única no país a projetar e produzir tais peças, fornecendo para a Ford e outras montadoras que se instalavam aqui.

Gastão desenvolveu além do design das peças, a diagramação do produto, das embalagens, definindo inclusive o sistema de gravação com 0 uso de pantógrafos e serigrafia, numa época em que a técnica 

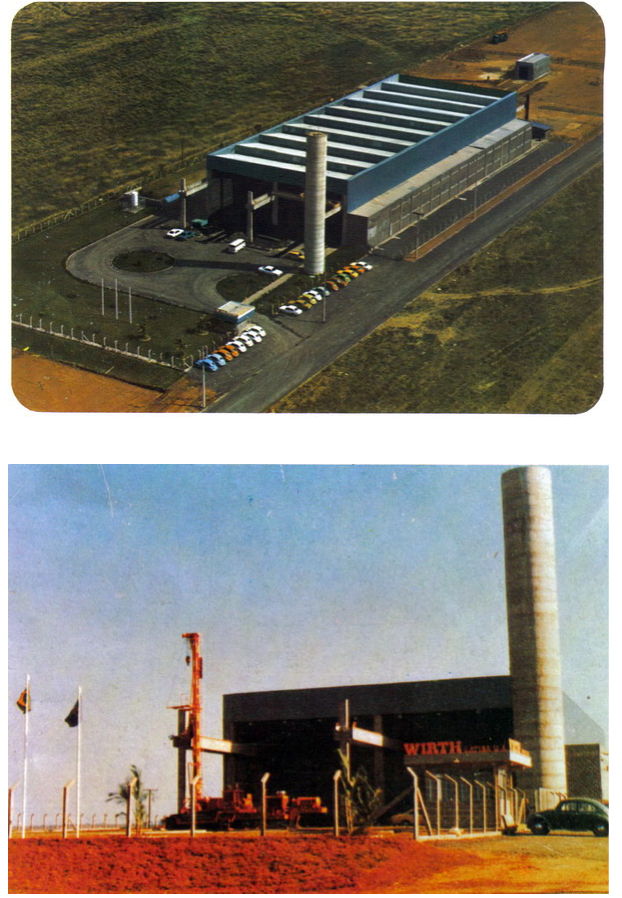

Acima a abaixo: Fábrica da Wirth Latina em São Carlos. projeto: Luiz Gastão de Castro Lima.

Fonte: Folder institucional da empresa fornecido por Luis Paulo Lavoie à autora serigráfica era ainda muito pouco explorada no Brasil e totalmente desconhecida na cidade.

Segundo depoimento de Luis Paulo Lavoie, filho de Roch Lionel Lavoie, Luiz Gastão teve uma participação total no processo, desde a concepção das peças, envolvendo-se em todo o processo de produção até o armazenamento e transporte do produto final.

"O Gastão participou com competência do processo químico da produção das peças, que na época eram executadas a base de resinas orgânicas e inorgânicas. Ele tinha uma visão abrangente e totalizadora. $\mathrm{Na}$ época, nem o projeto das peças nem a produção eram normatizados e o Gastão organizou todo o processo."22

À frente dessa produção, a Diamantul aumentou a gama de elementos produzidos, passando a fabricar além de brocas, todo equipamento necessário à perfuração a diamante. Reafirmando seu pioneirismo, a empresa lançaria a primeira sonda perfuratriz fabricada no Brasil, alcançando enorme repercussão no cenário nacional e grande sucesso no mercado da construção civil.

Neste momento, a Diamantul se une à empresa alemã Wirth Latina e parte da área do Jockey Club $\left(66.000 \mathrm{~m}^{2}\right)$ é destinada à construção da nova sede. Por indicação de Lavoie, Luiz Gastão é convidado a elaborar o projeto da nova fábrica. Havia concluído recentemente o projeto da primeira fábrica da Sanyo em Manaus e inicia o projeto da Wirth Latina em 1977.

Segundo Lavoie, técnicos alemães ligados à empresa vieram ao Brasil para acompanhar o projeto.

\footnotetext{
${ }^{22}$ Luis Paulo Lavoie (filho de Roch Lionel Lavoie) em entrevista concedida à autora em 31/10/2007
} 


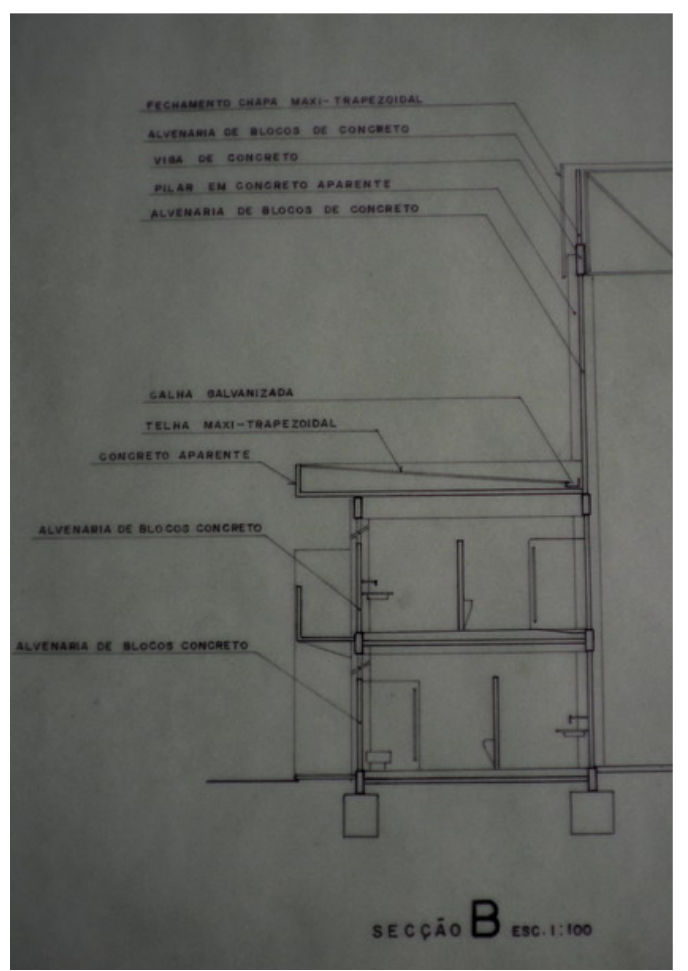

Fábrica da Wirth Latina. Acima: corte B. Abaixo: plantas e corte C. Acervo do arquiteto.
"O Gastão participou de várias reuniões com os alemães. Ele era uma autoridade no assunto. Foi exigência deles que se usasse no projeto da Wirth, uma chapa sueca. Não sabíamos do que se tratava, mas o Gastão já a conhecia."

Muitas das peças projetadas e fabricadas pela Wirth Latina em São Carlos, foram destinadas às obras da Usina Angra 2 (iniciadas no início dos anos 80) e da Ponte Rio-Niterói (iniciada em 1969).

Em 1986, uma empresa belga denominada Diamant Boart S.A. se interessou em assumir o controle acionário da Diamantul. ${ }^{23}$

A passagem de Luiz Gastão pela Diamantul foi decisiva para a coleta de dados e experiências que foram traduzidos em sua tese de doutoramento e aplicados no ensino do desenho na EESC e mais tarde, na estruturação do curso de Engenharia de Produção da UFSCar.

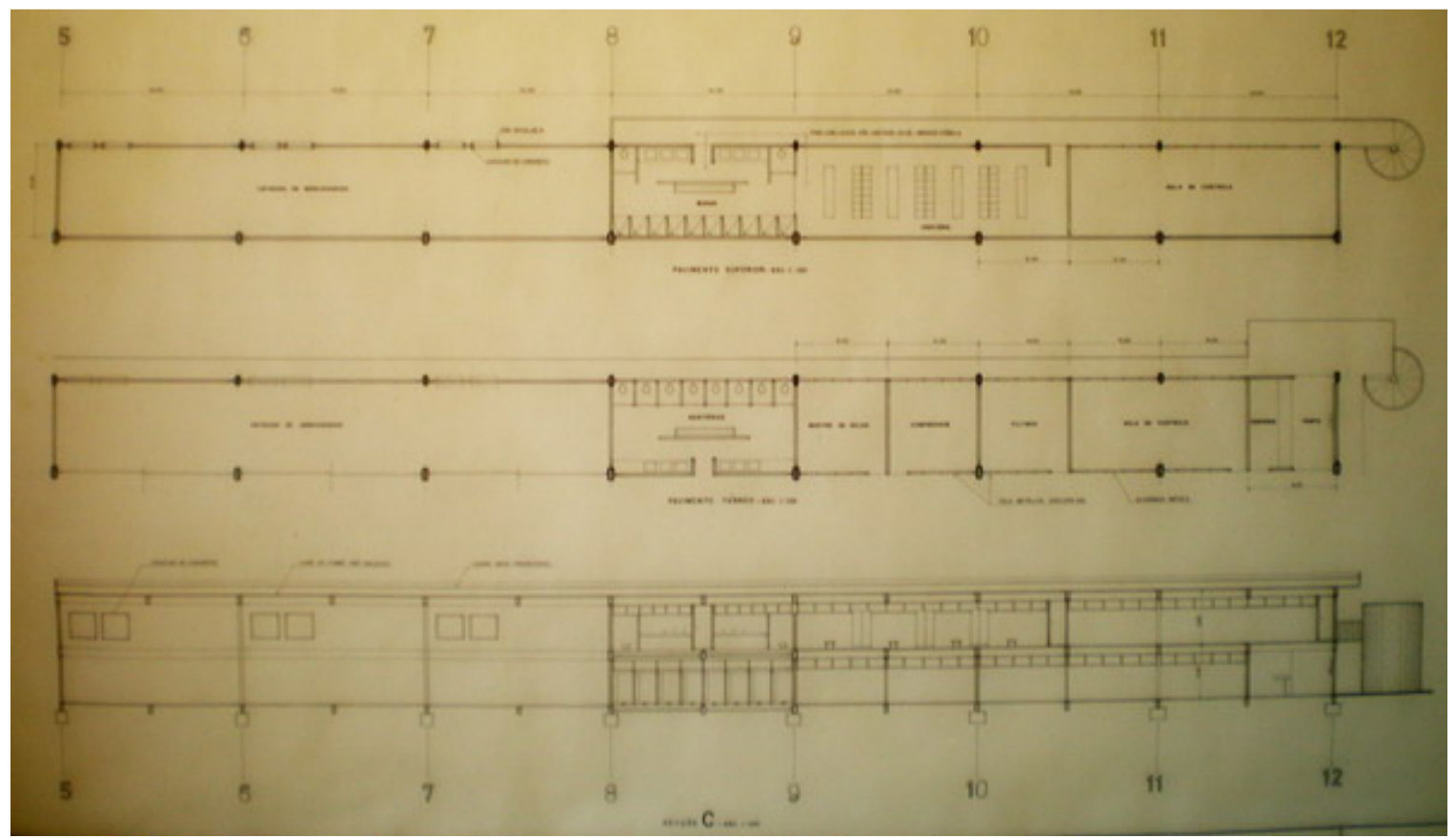

\footnotetext{
${ }^{23}$ As informações sobre o histórico da Diamantul foram retiradas de texto em homenagem à Roch Lionel Lavoie, publicada no site da ABAS (Associação Brasileira de Águas Subterrâneas) disponível no link : http://www.abas.org/index.php?PG=abas_news\&DET_ABN=00068

São também uma síntese da entrevista concedida à autora, por Luis Paulo Lavoie. São de Luis Paulo Lavoie, as informações sobre a passagem de Luiz Gastão pela empresa.
} 

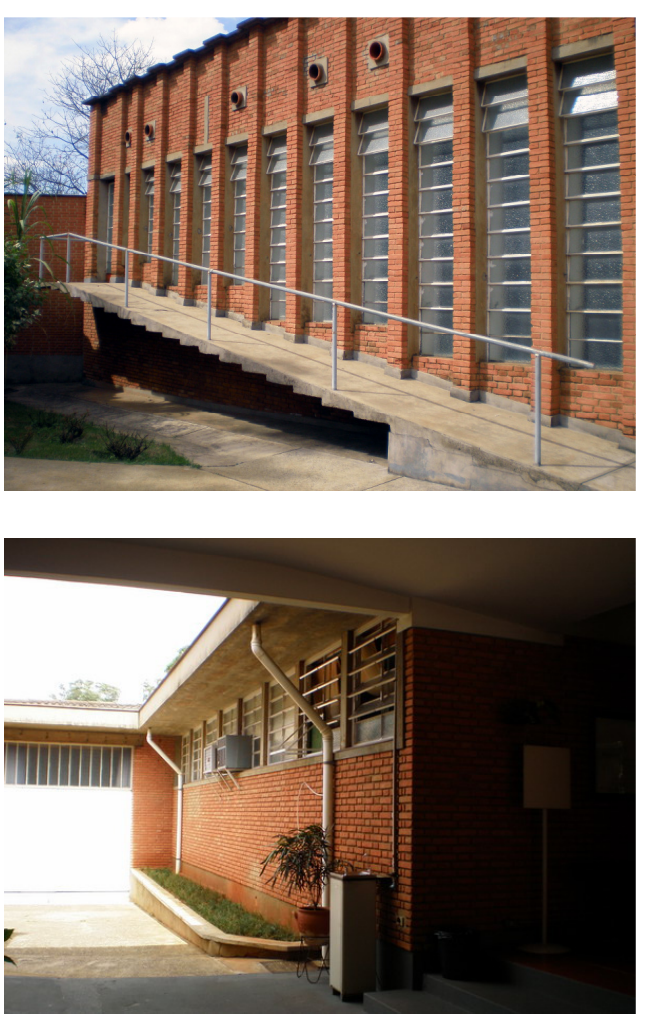

Anfiteatros e Departamento de Mecânica. ESALQ. Fonte: Prefeitura do Campus. Fotos da autora
Os edifícios da ESALQ

Em 1963, retomando a linha de projetos institucionais desenvolvidos durante o Plano de Ação, Gastão projeta os anfiteatros da Escola Superior de Agricultura Luis de Queiroz (ESALQ) em Piracicaba, nos mesmos moldes dos anfiteatros da EESC, porém com programa mais extenso. Dessa vez, os planos internos não se refletem mais em uma escada "anti-ergonômica", mas se transferem com mesma inclinação para uma rampa de acesso externo.

A planta se organiza a partir de um núcleo central onde se dá a entrada e se estabelecem os eixos de circulação. O conjunto é marcado mais uma vez pelo uso do tijolo, pela horizontalidade, águas rasas e beirais. As fotos atuais não revelam a arquitetura do edifício, devido à intensa vegetação que o circunda.
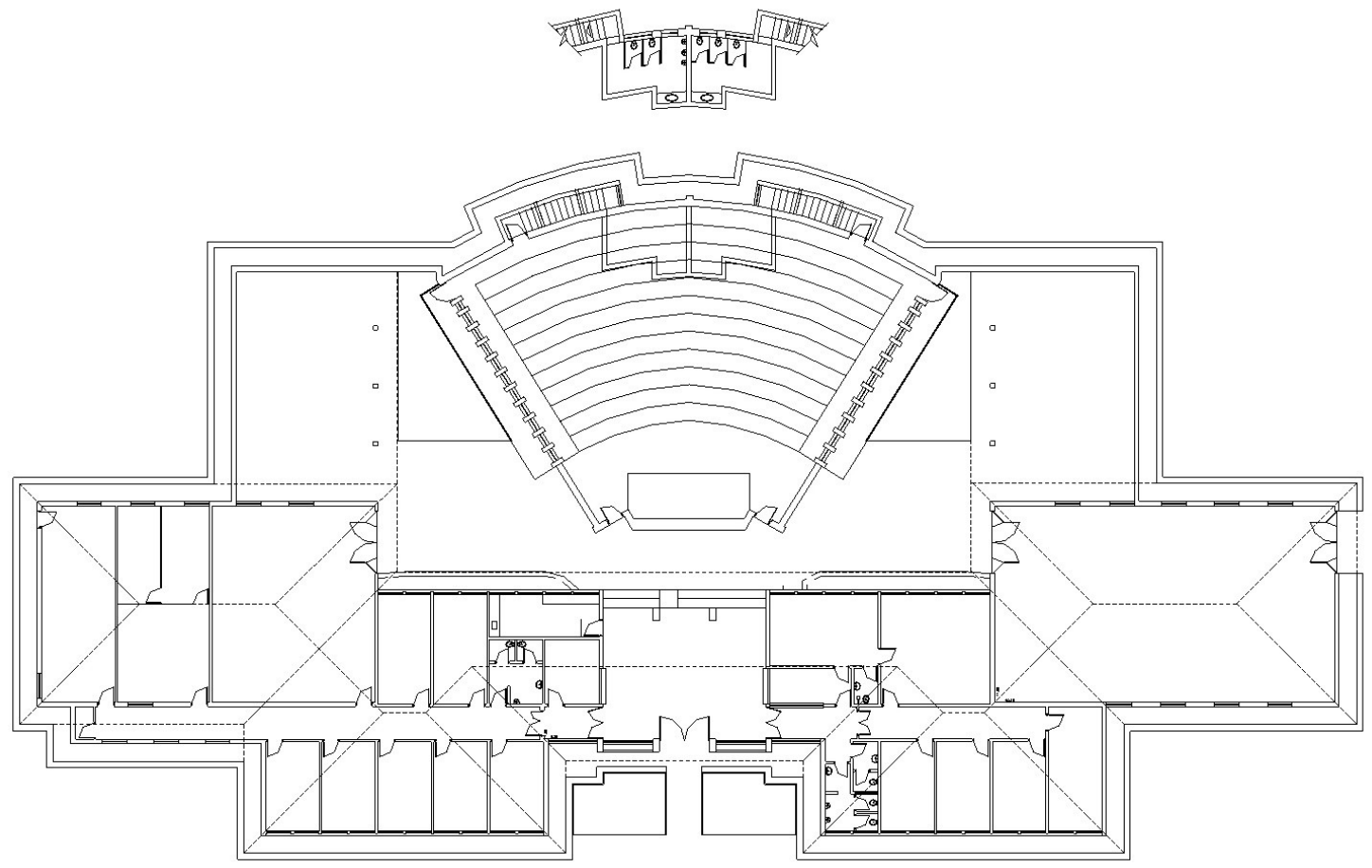

Anfiteatros e Departamento de Mecânica. ESALQ. Planta baixa. Fonte: Prefeitura do Campus ESALQ. 

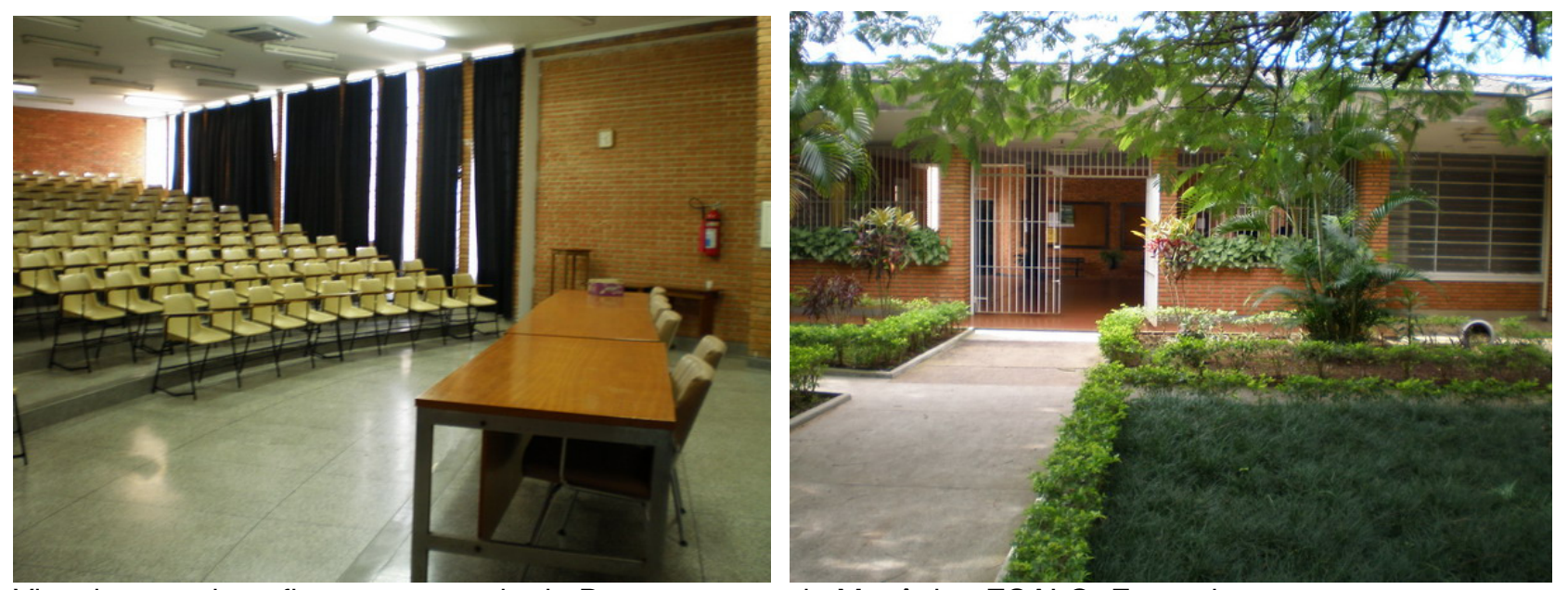

Vista interna do anfiteatro e entrada do Departamento de Mecânica-ESALQ. Fotos da autora

As salas de apoio se desenvolvem linearmente $e$ formam com o volume do anfiteatro, um conjunto fechado que dá origem a dois pequenos pátios internos que permitem soltar o volume do auditório do corpo de apoio didático. Os caixilhos ocupam toda altura do pé-direito e em alguns momentos, o arquiteto lança mão dos recursos de iluminação zenital.

\section{Duas bibliotecas}

No ano seguinte, Gastão realiza um projeto que sempre foi motivo de grande satisfação pessoal. Inserida em meio aos jardins da ESALQ, a primeira biblioteca da Escola tem traços expressivos da arquitetura wrightiana.

Gastão parece ter tido aqui mais liberdade de projeto que nos edifícios da EESC e a obra se manteve fiel aos detalhes projetados e calculados pelo arquiteto. Apenas recentemente, uma escada metálica lateral foi instalada para atender às necessidades do novo uso, mas não interveio de modo a descaracterizar o edifício. $O$ que não aconteceu no edifício da biblioteca construído na EESC cinco anos mais tarde, que sofreu diversas 
modificações ao longo da construção, além de ter recebido posteriormente um corpo anexo aderido ao primeiro prédio, que não dialoga de forma harmônica com este.

Tanto a biblioteca da EESC (1969) como da ESALQ (1964) seguem o partido da planta articulada em dois volumes interligados por um corpo central que concentra e distribui a circulação. A estrutura em concreto é deixada à vista em ambas as construções.
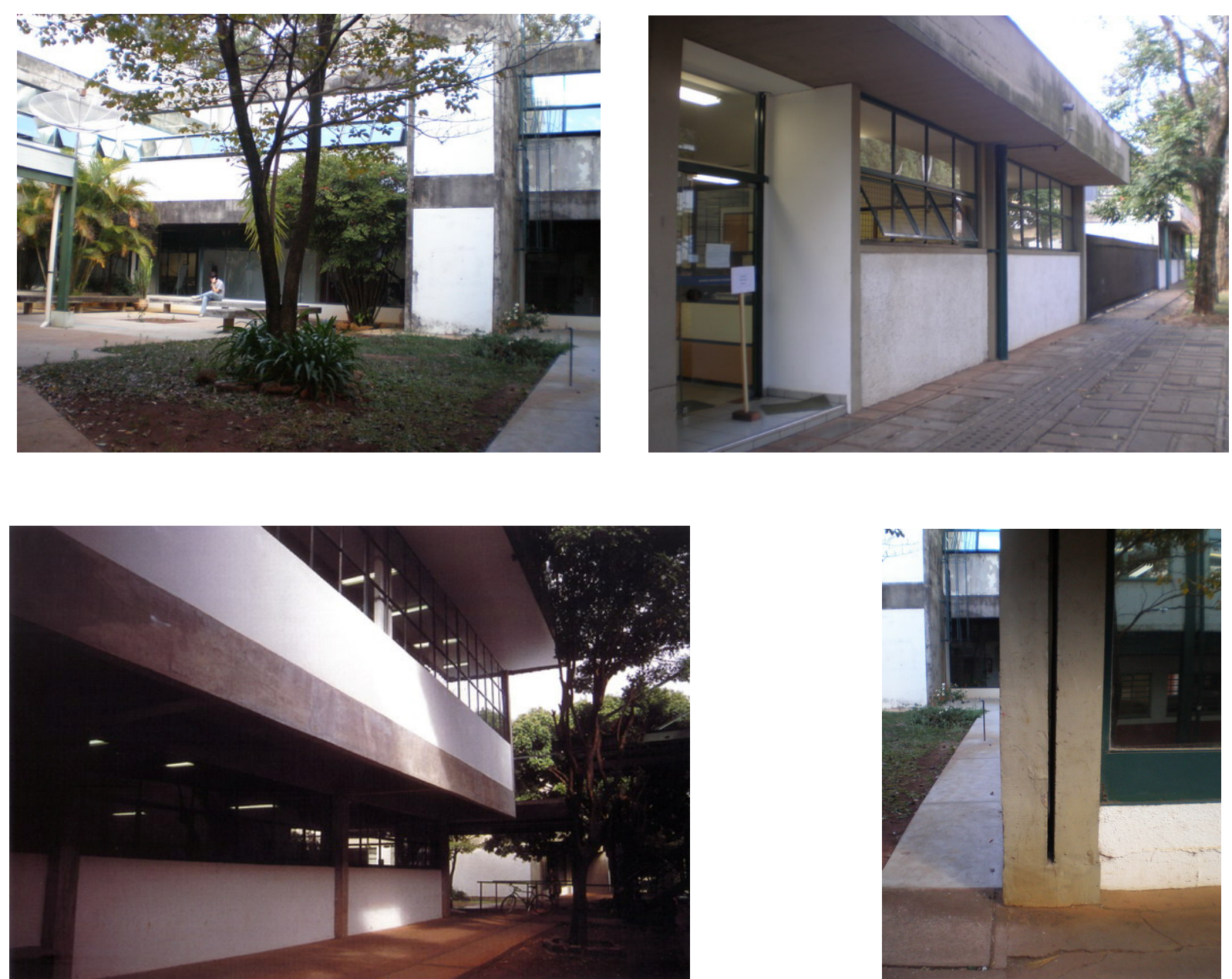

Biblioteca EESC USP. Vistas externas e detalhe do pilar. Fonte: Fonte: abaixo à esquerda: Lanna (2005). As demais, fotos da autora. 


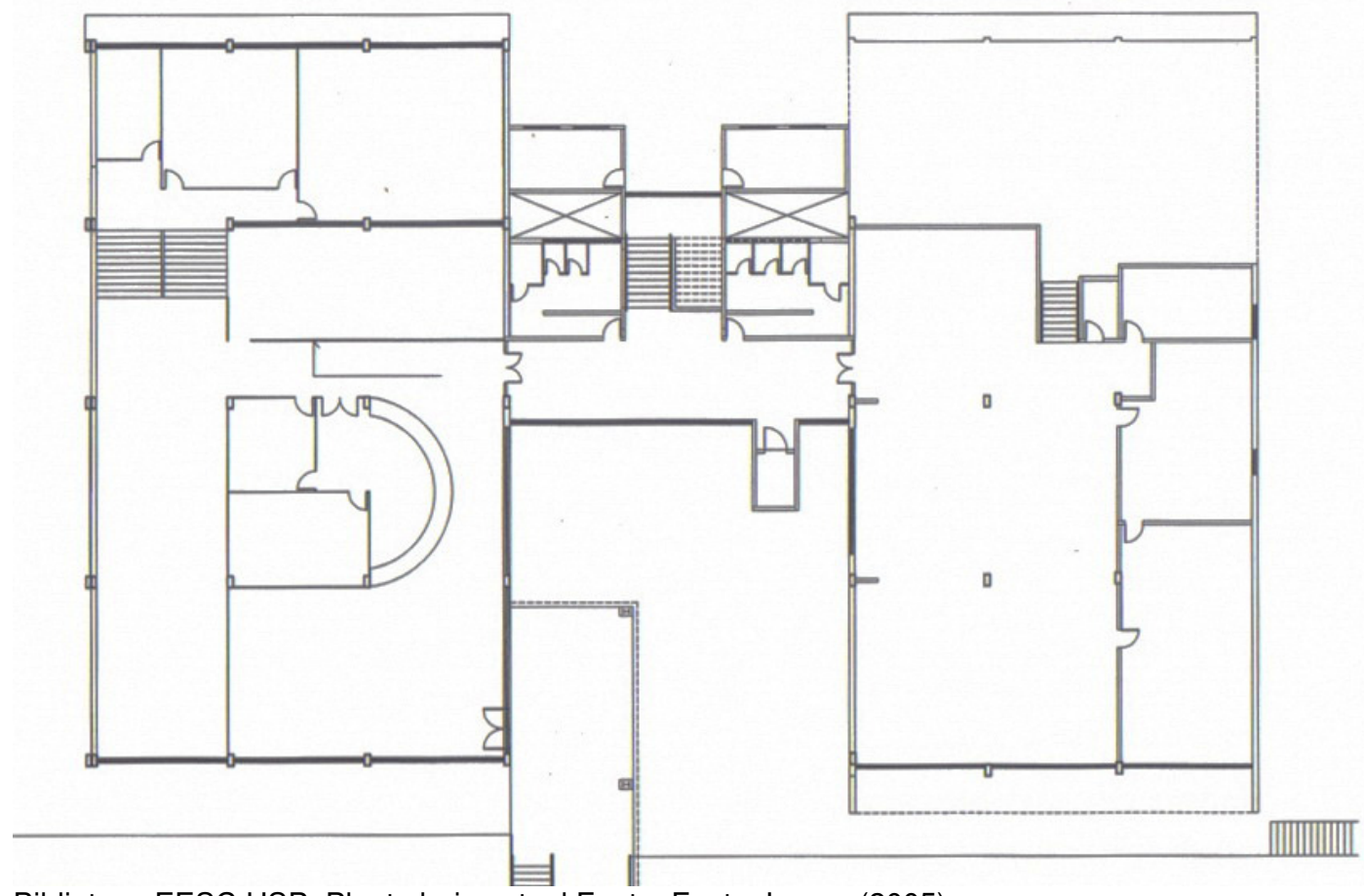

Biblioteca EESC USP. Planta baixa atual Fonte: Fonte: Lanna (2005)

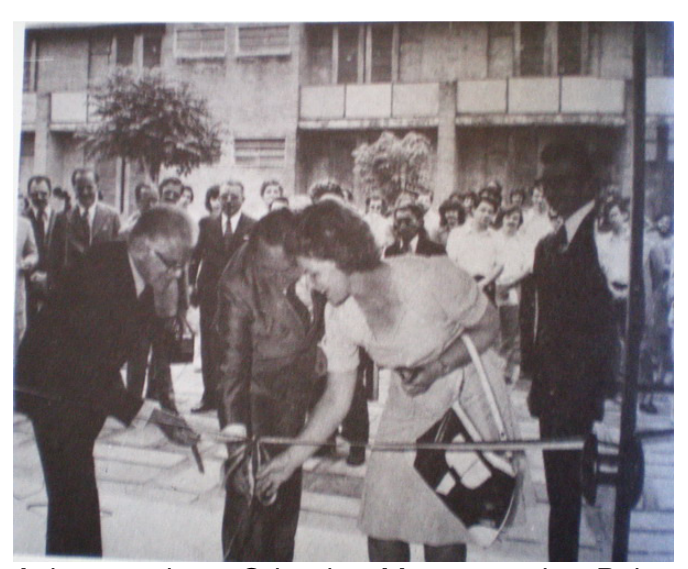

Acima: reitor Orlando Marques de Paiva, prefeito Mario Maffei e Prfa. Lucila Arouca na inauguração da Biblioteca Central da EESC. Fonte: EESC. Encarte. Publicação interna. Abaixo: A biblioteca ainda em construção, com a entrada original voltada ao pátio interno do Alojamento. Fonte: Fundusp
O prédio da EESC se distancia da organicidade do edifício da ESALQ adotando uma postura mais racionalista no uso da cor branca e nos rasgos horizontais que percorrem a fachada do piso superior. As platibandas se lançam em balanço estendendo-se do corpo do edifício, criando áreas de sombreamento. 0 volume se fecha totalmente para a praça adjacente e o acesso se dá lateralmente através de um caminho estreito e nada convidativo. Esta foi mais uma das alterações sofridas pelo projeto original que se voltava inteiramente ao prédio dos alojamentos, numa atitude visível de unir o aluno à pesquisa.

Duas fotos da época revelam o intuito do projeto original: a construção do edifício e o momento de sua inauguração, onde se vê o corte simbólico da faixa inaugural logo à entrada e o alojamento como pano de fundo. 


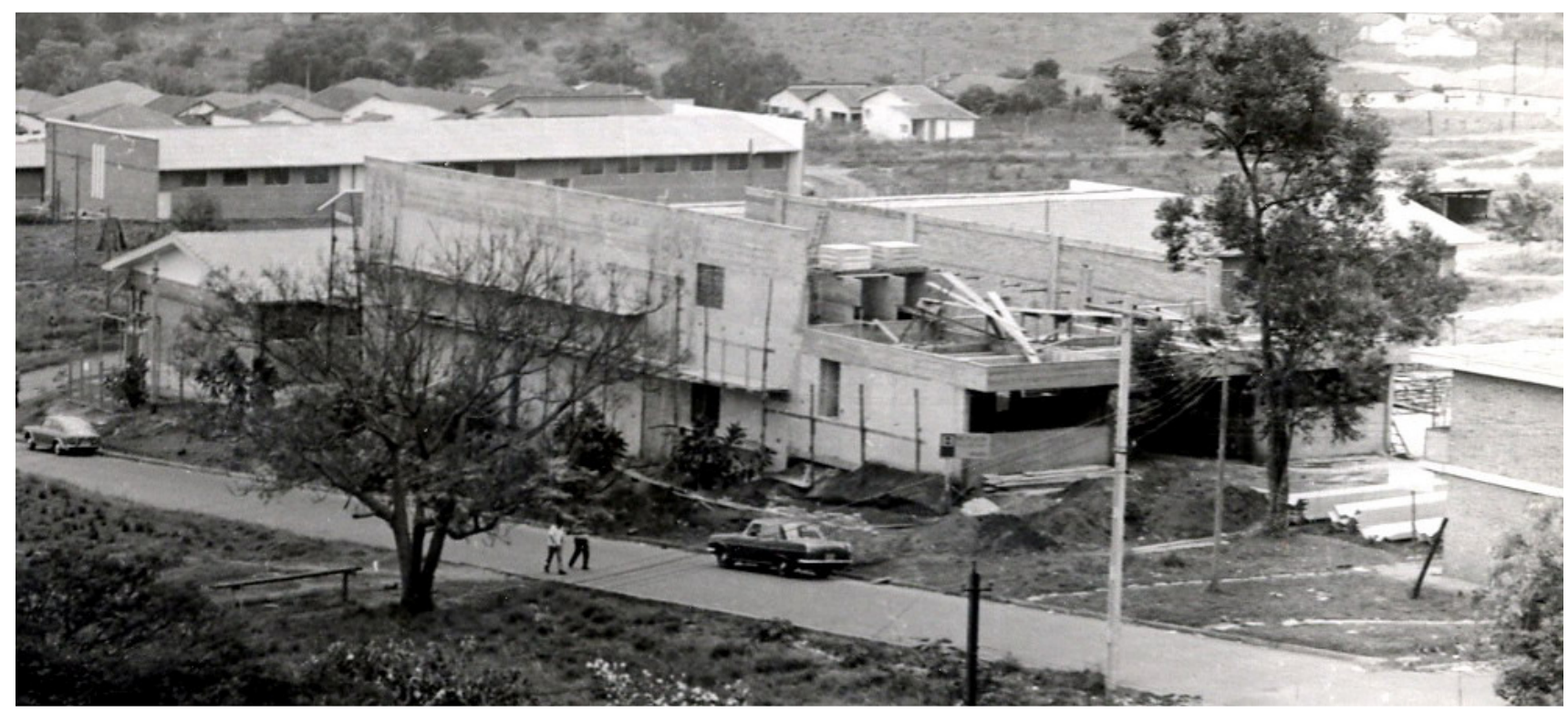

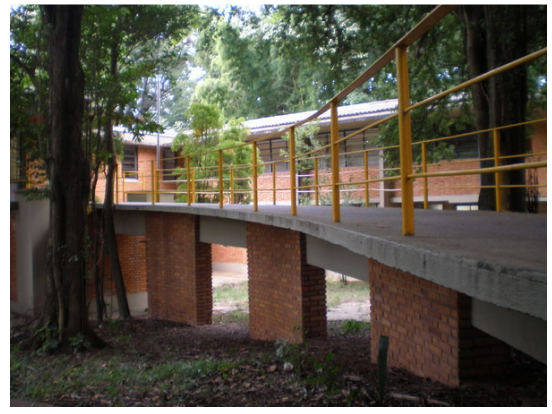
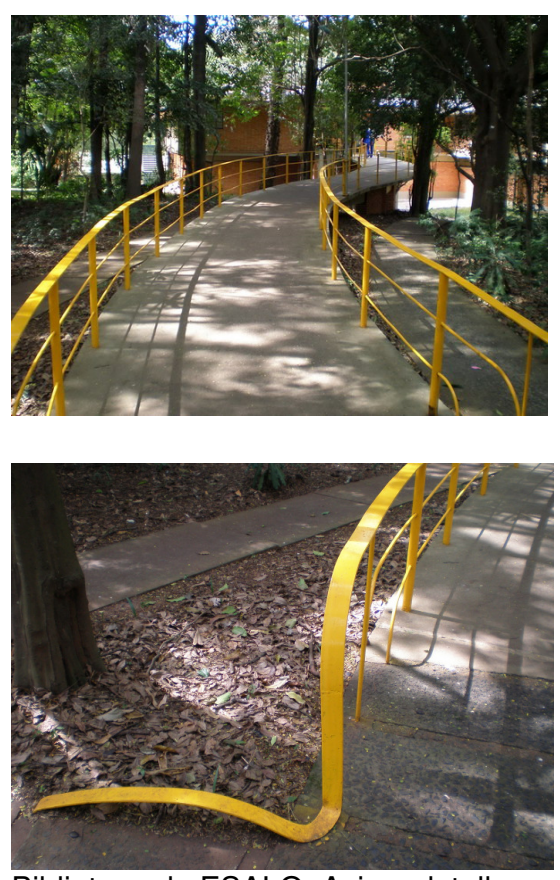

Biblioteca da ESALQ. Acima:detalhes da rampa. Abaixo: detalhe beiral e janela de canto. Fotos da autora
Diferentemente da EESC, onde os edifícios foram implantados seguindo um planejamento moderno, a implantação do campus de Piracicaba segue o modelo dos jardins ingleses, que prezam pelo conceito de perspectiva. Sob este enfoque, embora contasse com uma vasta área, o campus universitário da ESALQ não dispunha em seus domínios de um espaço livre para a nova edificação. Todo local disponibilizado ficava em meio às vistas determinadas pela disposição dos jardins. Uma área remanescente, teoricamente fora desse jogo de vistas privilegiadas, com topografia irregular e situada abaixo do nível da rua foi destinada à implantação da biblioteca.

O projeto considerou as características naturais do sítio, mantendo o perfil original. O acesso principal se dá por meio de uma rampa sinuosa estruturada através de uma viga central. Esta mesma viga recolhe a descida de toda rede hidro-sanitária localizada inteiramente no pavimento superior. A planta se articula em dois blocos unidos por um corpo central onde se concentra a circulação vertical e alguns serviços comuns, como copa e sanitários. 


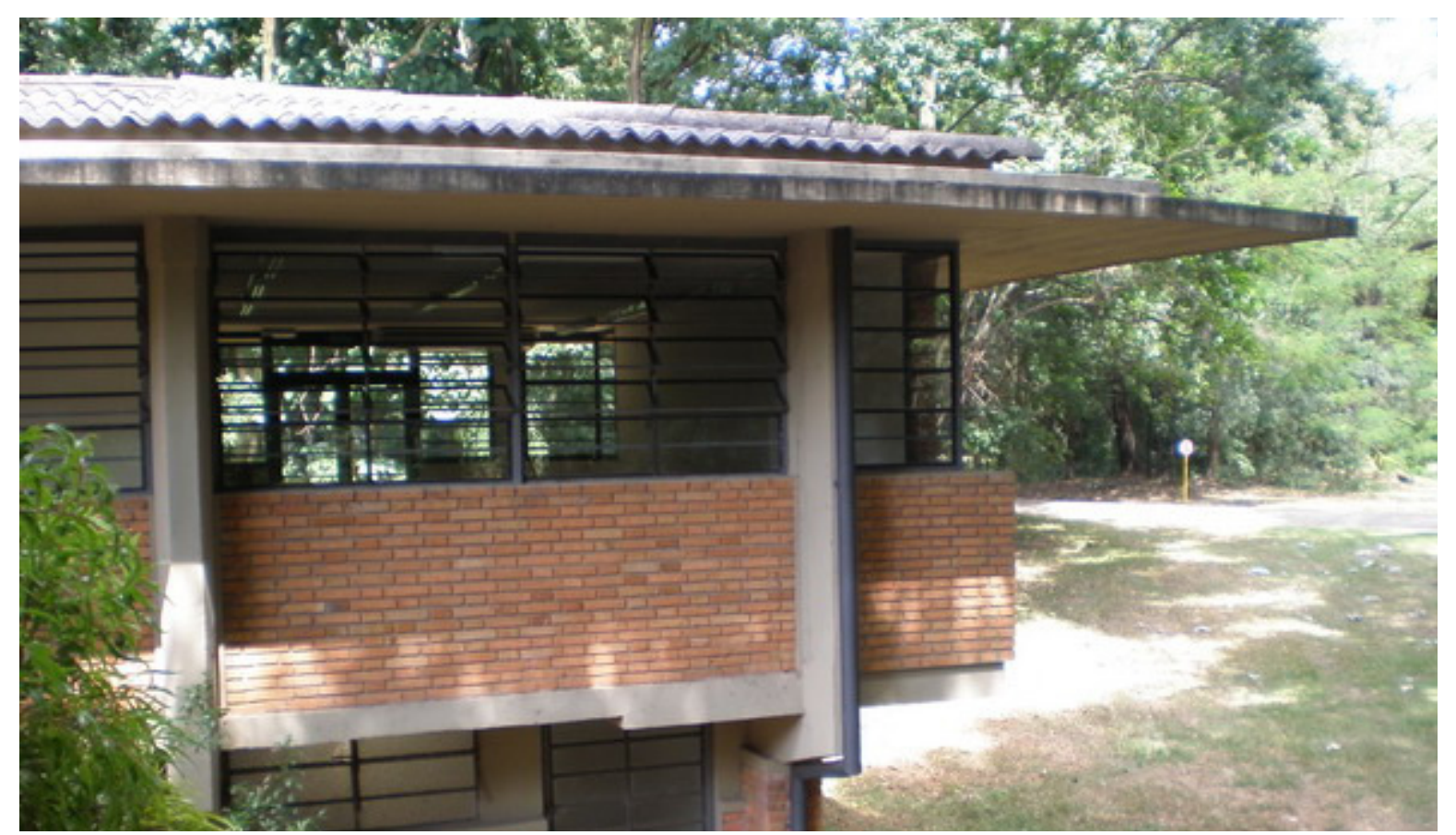

Uma seqüência de vigas em $U$ apoiadas sobre pilares no térreo estrutura 0 segundo pavimento sustentando uma lâmina em concreto que circunda todo o perímetro. Essa lâmina se projeta externamente e formando um beiral. Acolhe a calha na parte externa e recebe na parte interna toda a fiação, criando uma sanca de iluminação.

Aqui Gastão lança mão das janelas de canto e se remete à Wright na opção pela planta articulada em dois blocos unidos por um corpo central. No entanto não usa o corpo central como entrada principal, elegendo para esse fim, um dos blocos. Gastão realiza não só o projeto de arquitetura, mas também todos os projetos complementares do edifício:

Dando, evidentemente, uma re-estudada em alguns assuntos, eu comecei a calcular as estruturas de concreto das obras que eu projetei e fiscalizei e algumas até relativamente grandes, como, por exemplo, a 

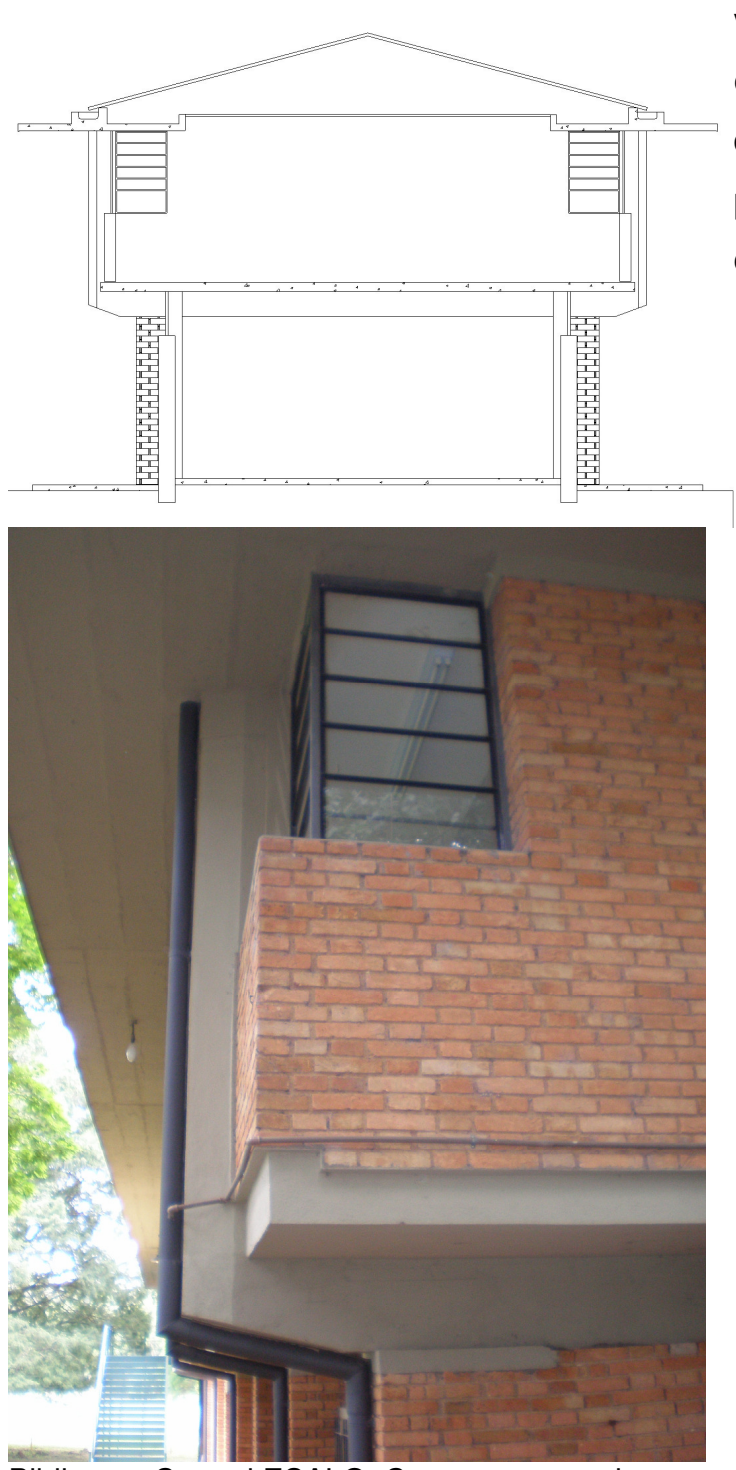

Biblioteca Central ESALQ. Corte transversal e detalhe da janela de canto.Fonte: Prefeitura ESALQ. Foto da autora biblioteca central da Escola Superior de Agricultura Luis de Queiroz, que tem vãos grandes, cargas grandes.

E talvez eu tenha me tornado a essa altura um dos únicos arquitetos brasileiros capaz de dimensionar e calcular as estruturas do seu próprio trabalho. Com hipóteses, processos, diga-se de passagem, que sem dúvida alguma fariam empalidecer de susto calculistas profissionais.

Sobre isso não tenho dúvida nenhuma. Mas muitas vezes eram alicerçados numa observação e na experiência, muitas vezes manual, da própria execução da obra, do comportamento da estrutura. Então isso permitia que eu me desse ao luxo ou à ousadia de calcular e dimensionar as peças. ${ }^{24}$

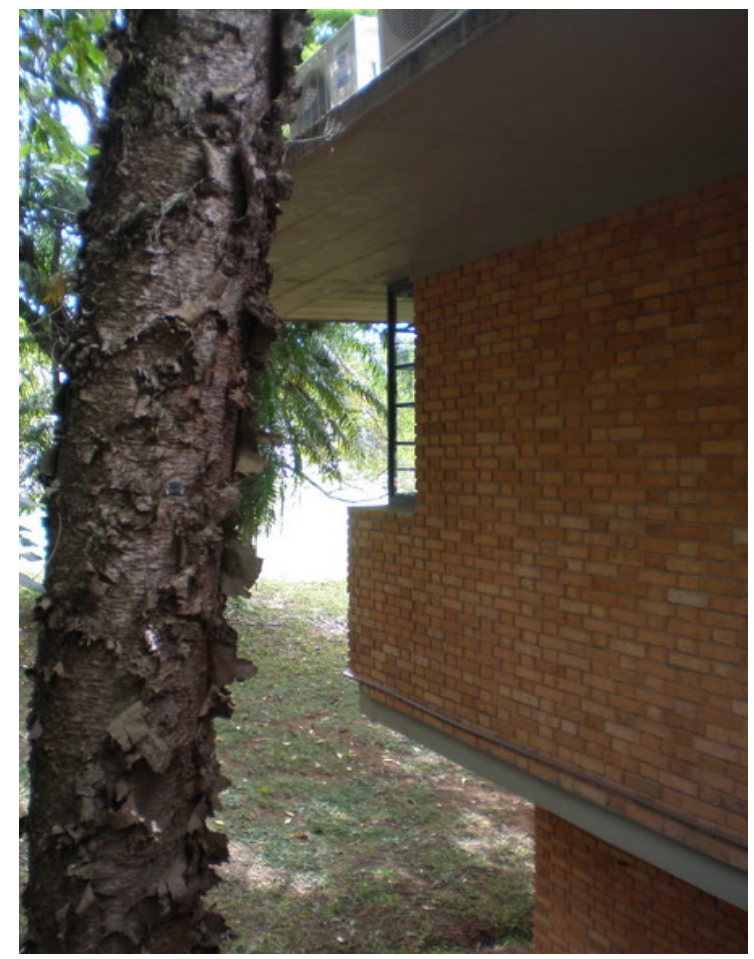

${ }^{24}$ Luiz Gastão de Castro Lima em INSTITUTO DOS ARQUITETOS DO BRASIL - São Paulo. Arquitetura e desenvolvimento nacional: depoimentos de arquitetos paulistas. Pini, São Paulo, 1979. 


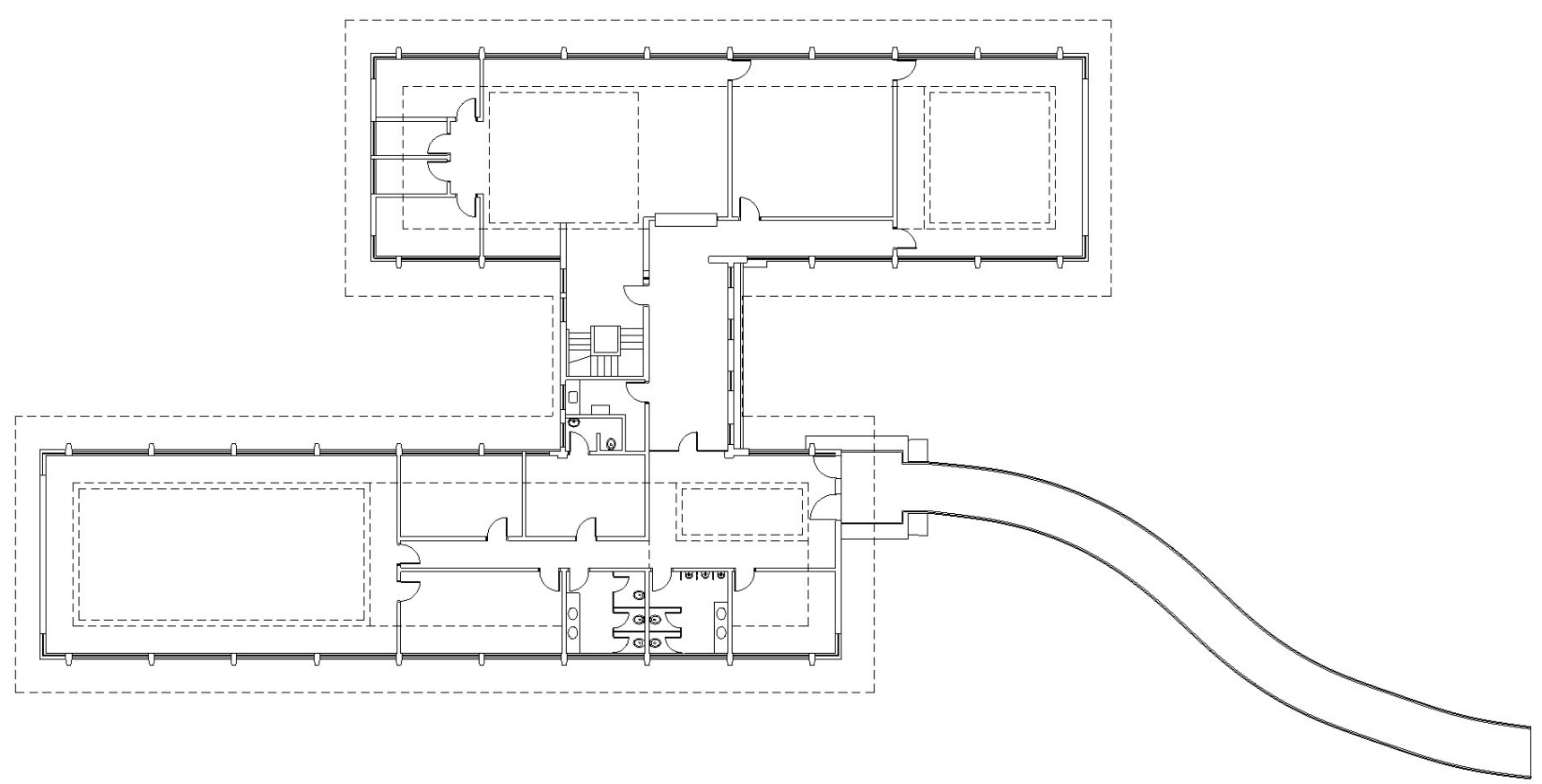

Acima: Planta Biblioteca Central Escola Superior de Agricultura Luis de Queiroz. Em projeção, a lâmina que circunda o prédio em todo o perímetro. Abaixo: corte e vista janela de canto. Fonte: Prefeitura do campus ESALQ e foto da autora.

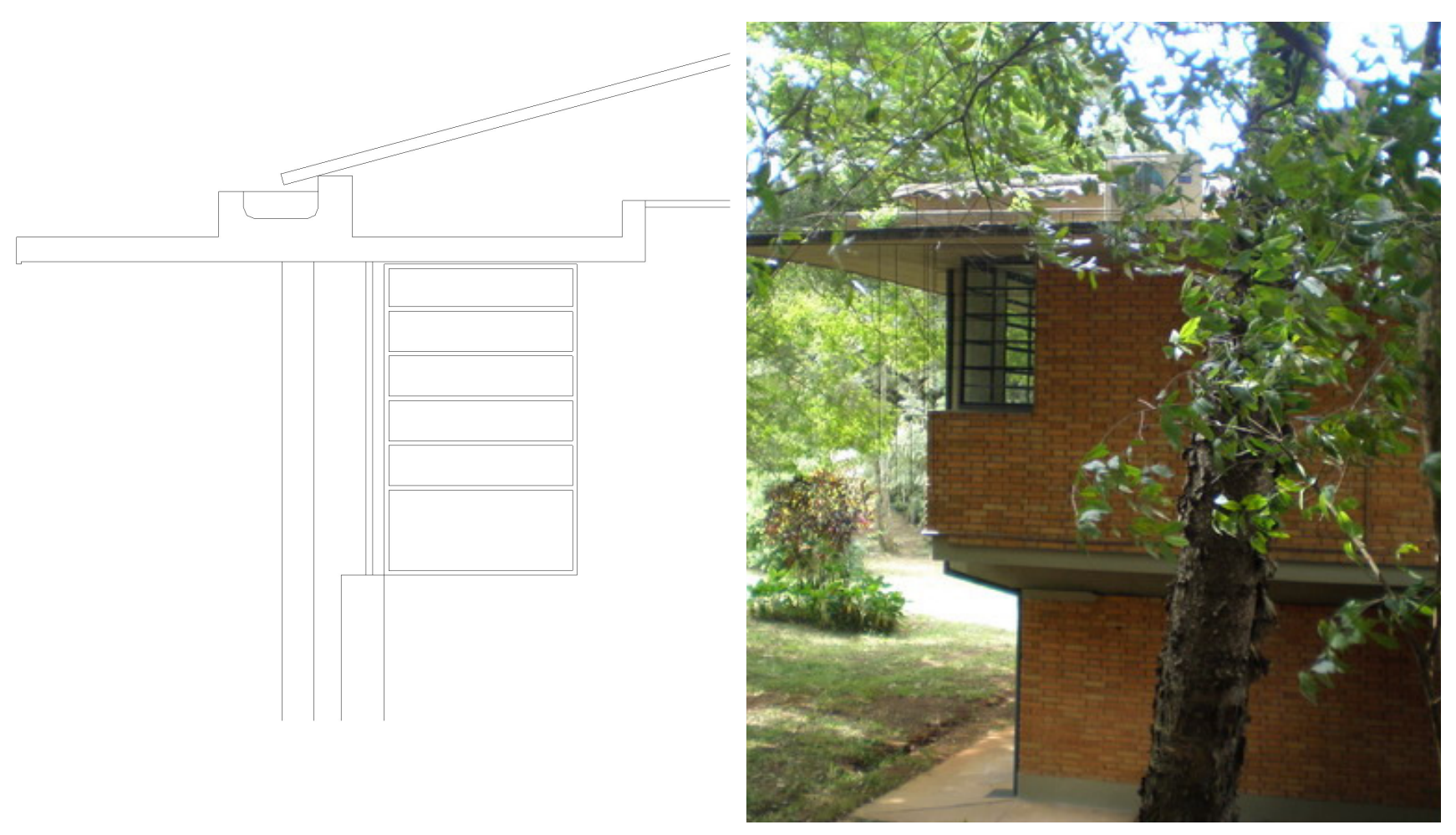




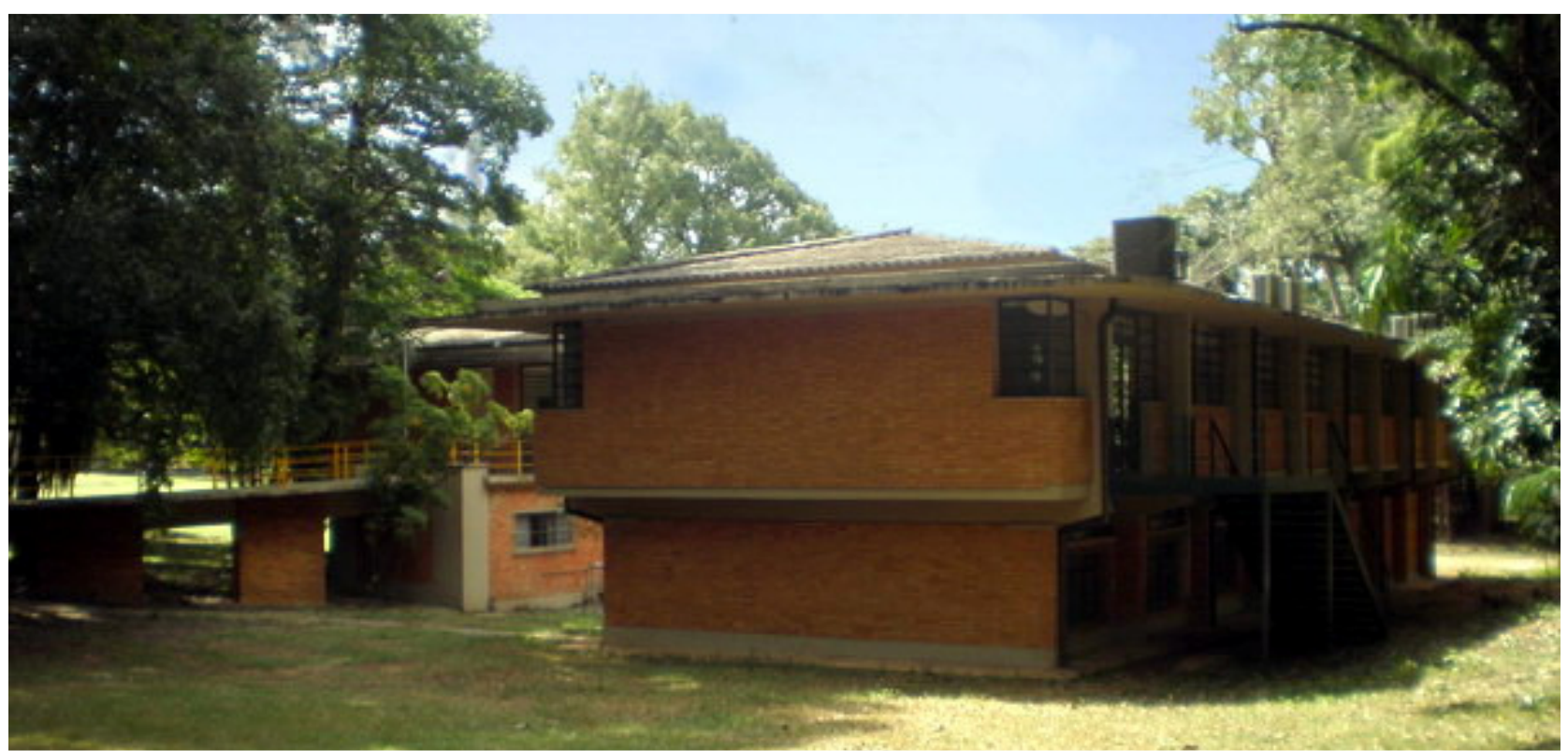

Outros aspectos que se remetem à Wright estão presentes na horizontalidade do conjunto, na fluidez do espaço por meio das generosas transparências, no uso do material bruto (tijolo e concreto aparente), nos amplos beirais, na suave inclinação da cobertura e nas aberturas de canto. Podemos ainda supor uma aproximação entre o gesto livre da curva sinuosa do corrimão às linhas dinâmicas de Alvar Aalto presentes entre outras, no corrimão da Biblioteca de Viipuri (1927-35) e no design da Paimio Chair (1932).
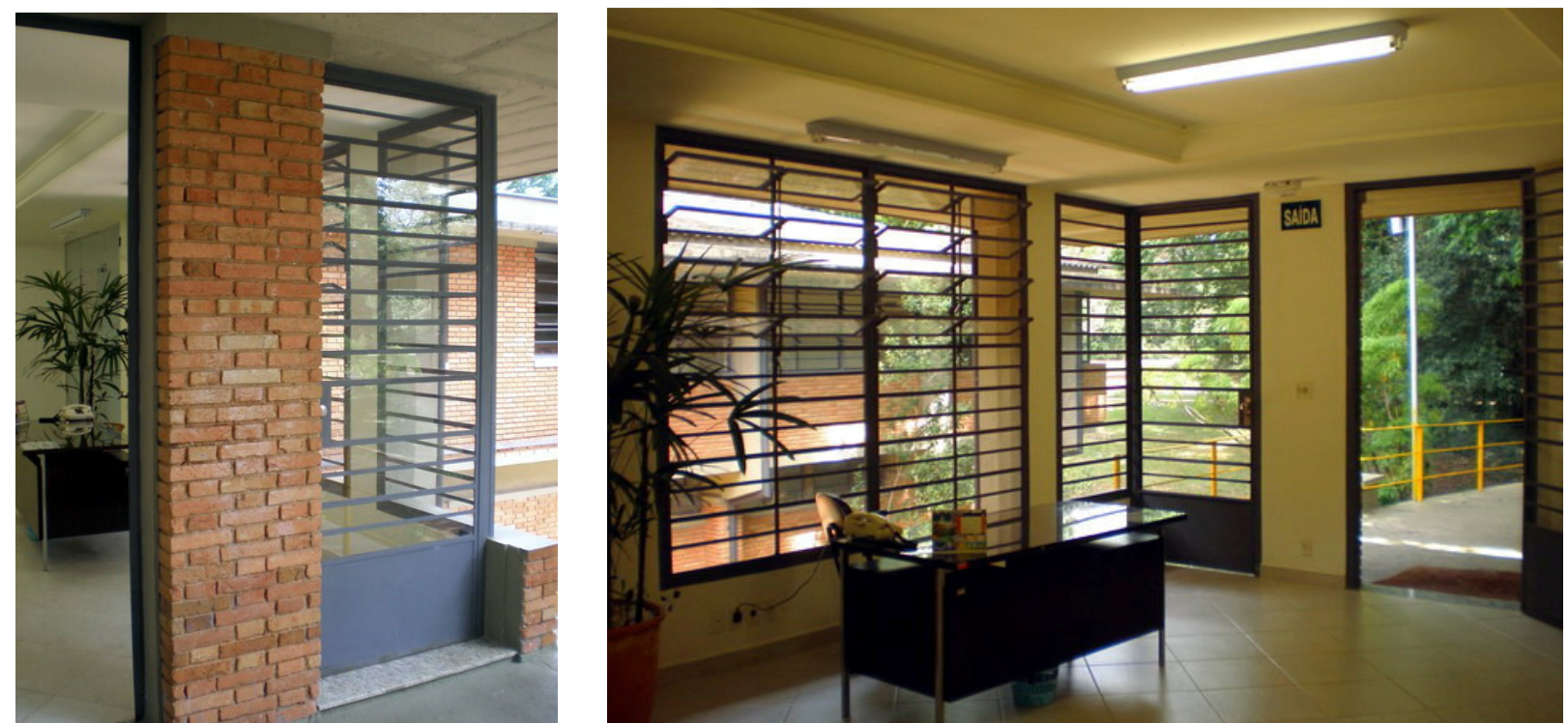

Acima: Detalhe da entrada e vista interna. Biblioteca da ESALQ. Na pág seguinte: detalhe do engate pilar e viga. Fotos da autora 


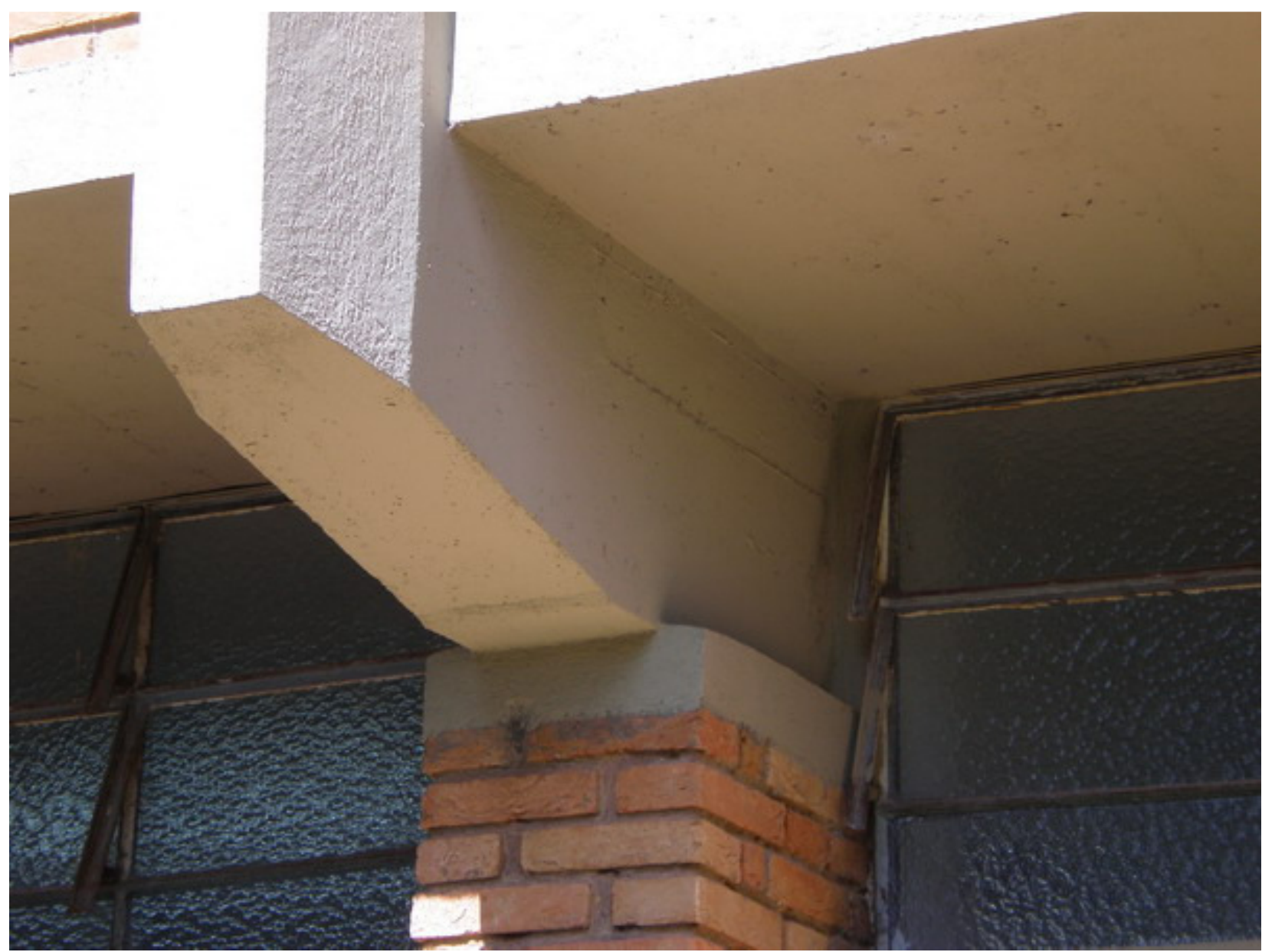

Detalhe pilar e viga. Biblioteca ESALQ. Foto da autora 


\section{CENA}

Em 1965, Gastão se envolve didaticamente com a ESALQ, oferecendo o curso Elementos de Desenho Industrial no curso de Pós Graduação de Elementos de Máquinas e Desenho Industrial. É nesse período que recebe o convite para elaborar o projeto do primeiro prédio do Centro de Energia Nuclear da Escola, o CENA.

$O$ projeto segue a mesma linguagem presente nos projetos institucionais anteriores e é marcado pela horizontalidade e pela presença do tijolo aparente. Foi um dos primeiros blocos implantados naquela região do campus e se transformou em modelo, sendo reproduzido por toda área adjacente ao prédio original. Isso teria causado grande descontentamento ao arquiteto. Segundo ele, o mesmo teria acontecido em Bauru, onde também chegou a elaborar projetos de apoio didático.

No prédio do Cena, os caixilhos formam uma seqüência ao longo da fachada, marcando o ritmo das aberturas e chegam até a laje de cobertura. $O$ baixo pé direito reforça a noção de horizontalidade. Mais uma vez, a linha branca da platibanda é marcante em contraste com o tom cerâmico do tijolo.

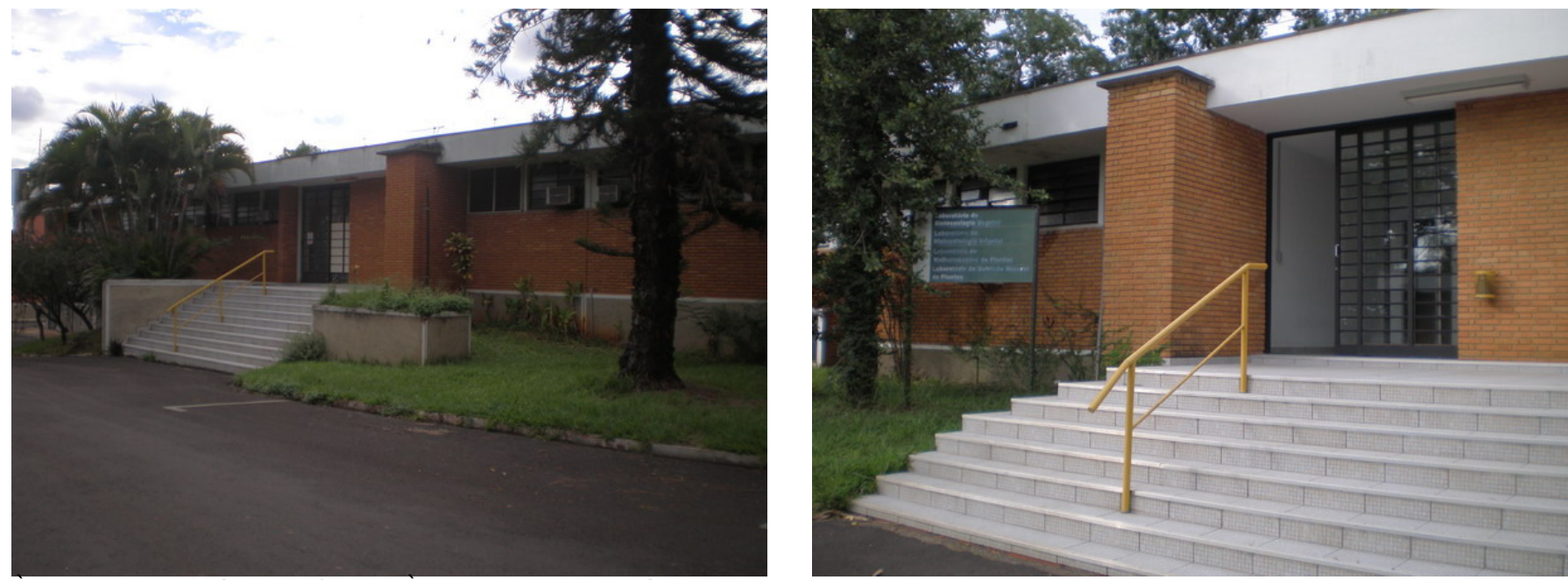



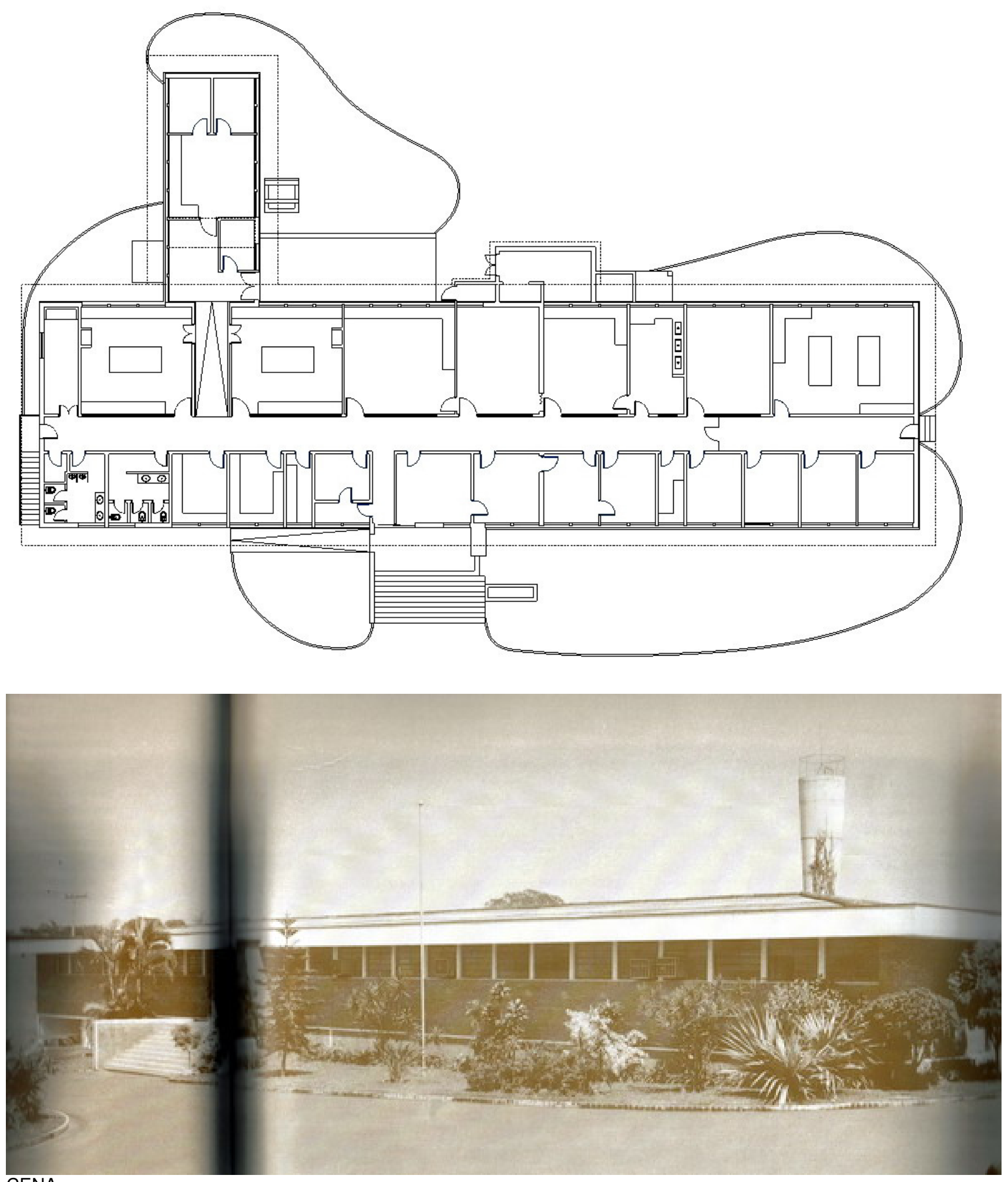

\section{CENA.}

Acima: Planta baixa. Levantamento métrico recente.Fonte: ESALQ. Prefeitura do Campus. Não há como afirmar que o traçado orgânico dos jardins circundantes seja de autoria de Luiz Gastão. Abaixo: Foto da época de inauguração. Fonte: Leão (1996) 
Gastão também elaborou na ESALQ o projeto para o Centro de Estudos de Solos. A linguagem dos edifícios anteriores é mantida, mas novos elementos surgem na fachada, substituindo condutores pluviais por gárgulas e pingadeiras.

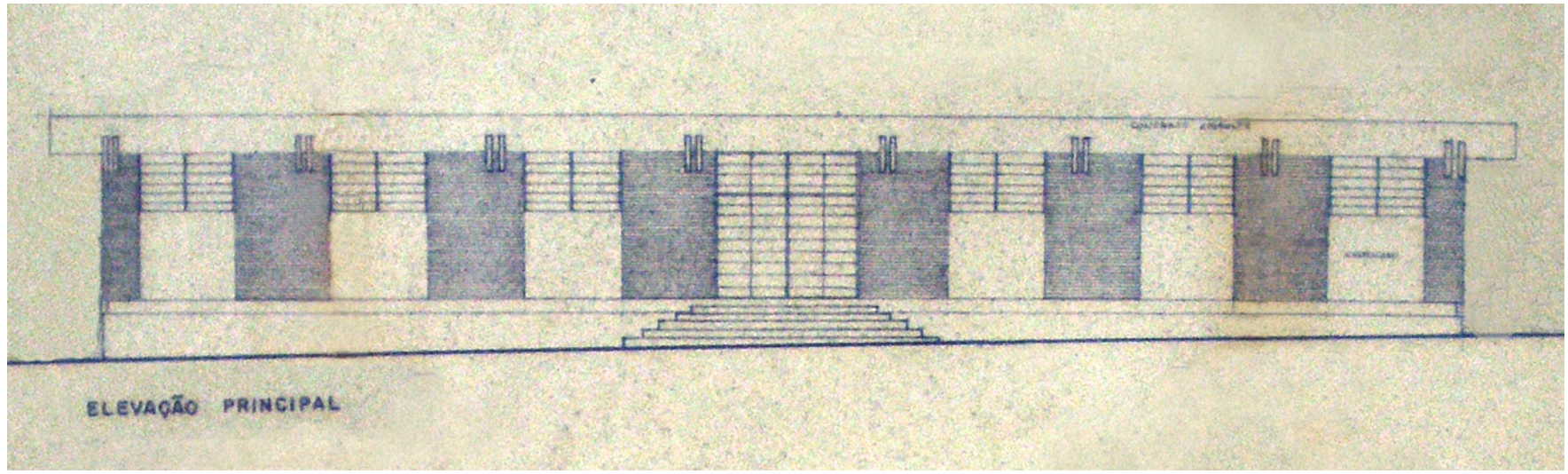

Centro de Estudos dos Solos. ESALQ. Acima: elevação frontal. Abaixo: detalhe da gárgula. Fonte: Prefeitura do Campus da ESALQ. Piracicaba. O prédio sofreu acréscimos posteriores, mas manteve suas características originais. Esse teria sido um dos méritos dos responsáveis pelo desenvolvimento físico da ESALQ, que além do esforço em documentar os projetos antigos, têm respeitado as arquiteturas ali existentes.

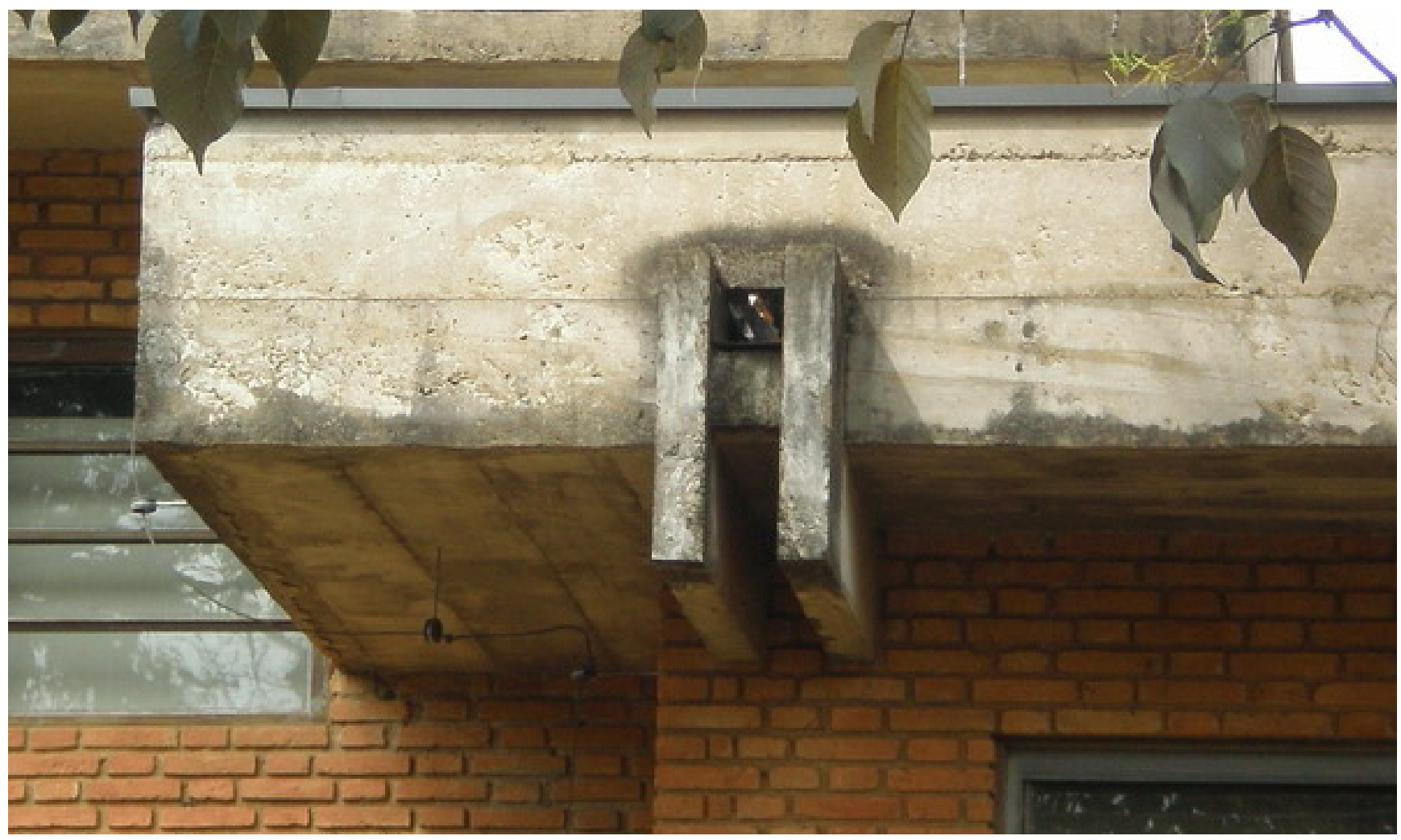




\section{ABRINDO CAMINHOS}

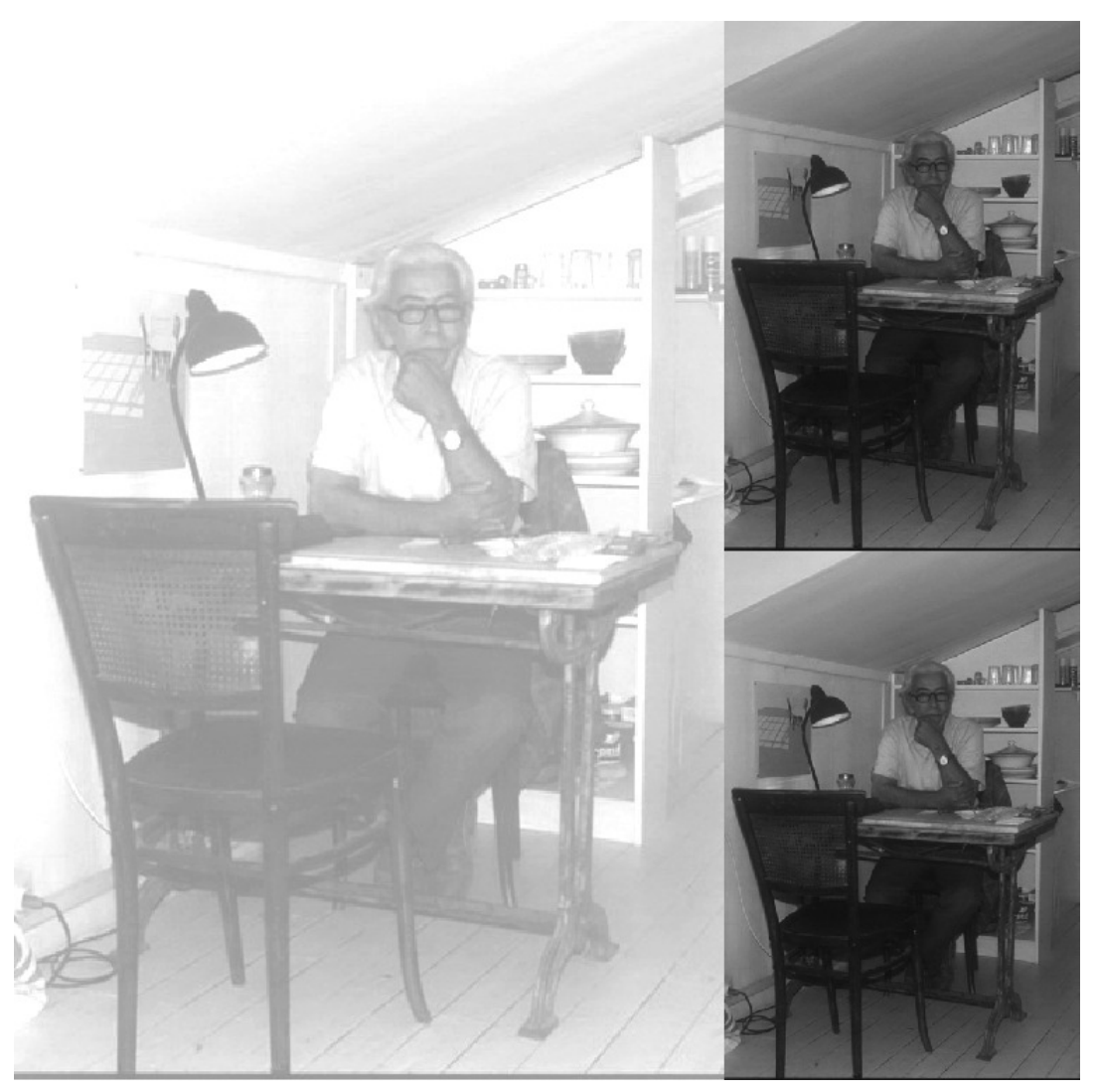


III - ABRINDO CAMINHOS

ENTÃO PENSEI, TENHO QUE DEIXAR UMA Mensagem de arquiteto, mesmo que

MINHA PROPOSTA NÃO SEJA

EXTRAORDINÁRIA.

SE fOREM VER AS COISAS qUE EU fIZ

provavelmente terão críticas a

fazer. alqumas severas até, mas

realmente o que me interessava é

QUE ESTAVA ABRINDO UM CAMINHO

PARA O ARQUITETO.

LUIZ GASTÃO DE CASTRO LIMA 
Residência Wilson Senise (1966)

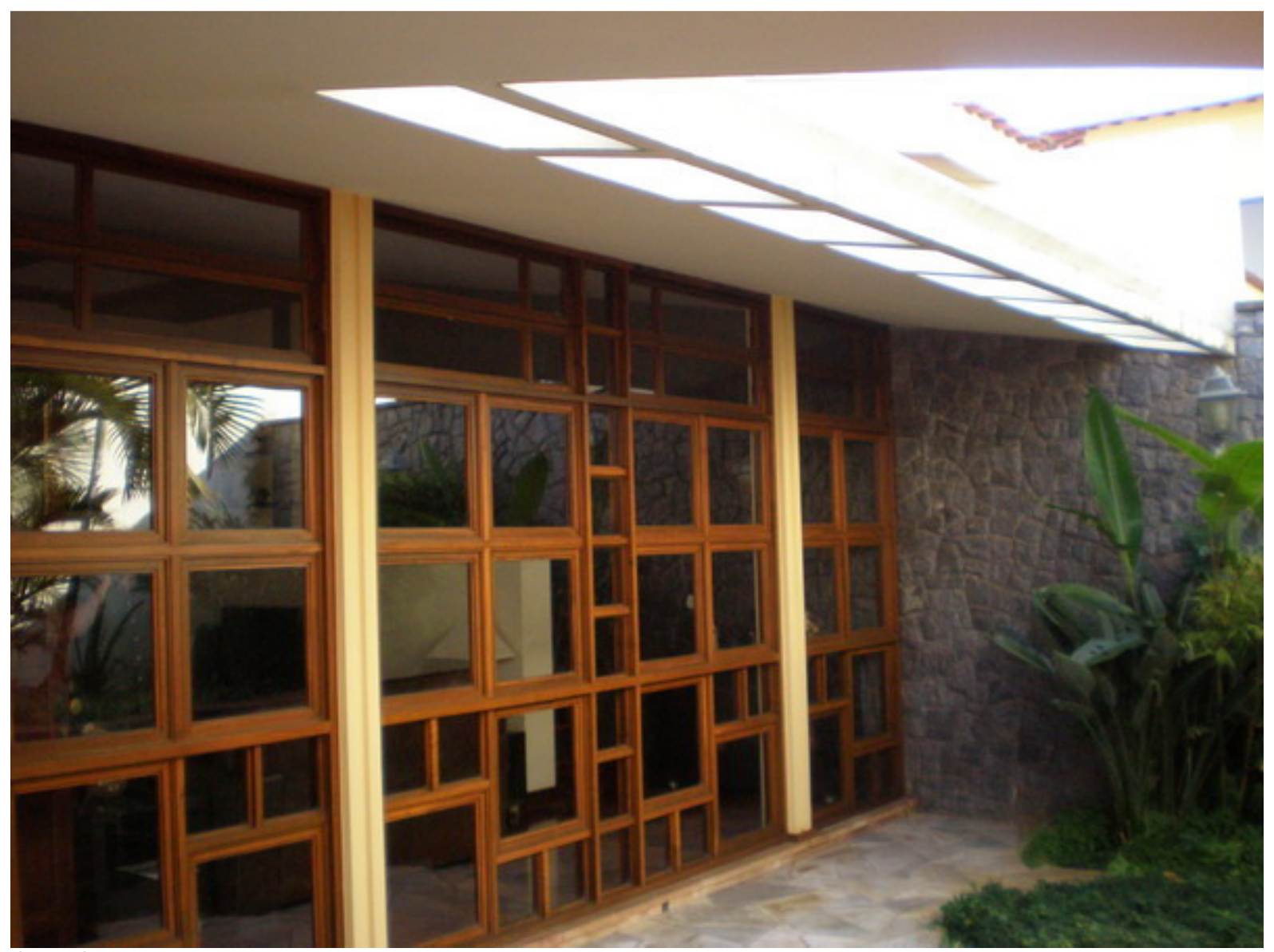

Casa Senise. Acima: vista do jardim. Abaixo, vista interior sala de estar e detalhe da entrada. Fotos da autora
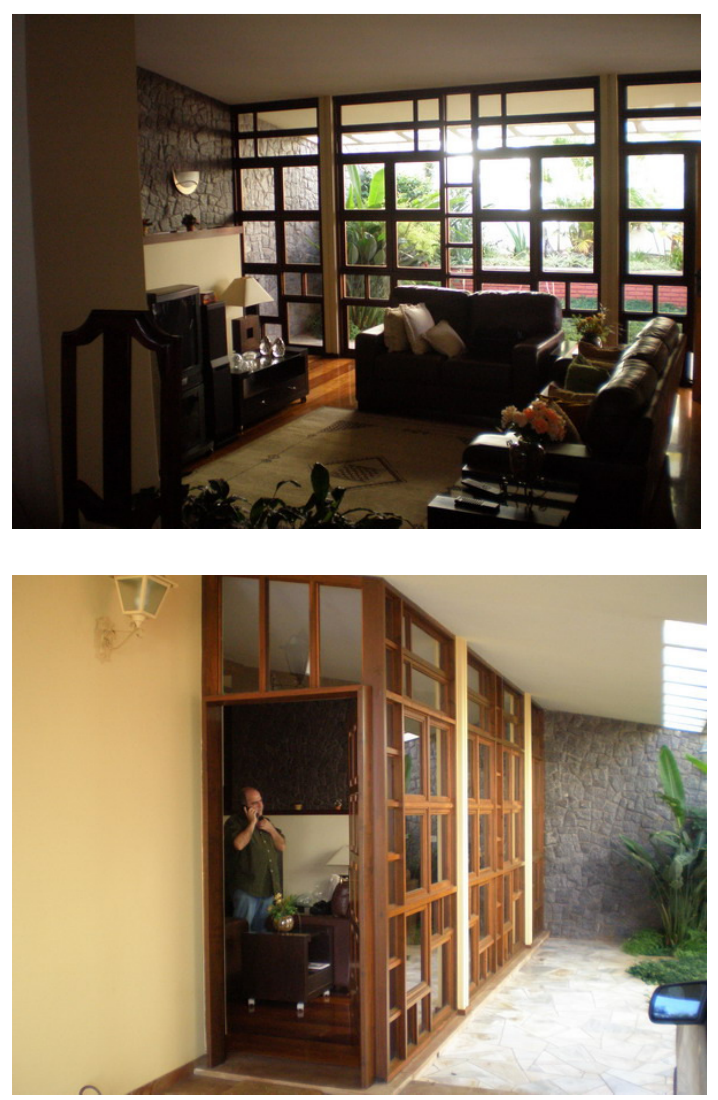

Em 1966, ano em que inicia disciplinas na FAU visando o doutorado, Gastão projeta a casa Senise, uma das maiores expressões wrightianas do conjunto da obra de Luiz Gastão, não só na concepção da planta, mas na composição de elementos e materiais, reunindo cores e texturas.

A parede em pedra que vem do jardim adentra a sala de estar integrando interior e exterior, ao mesmo tempo em que secciona a parte frontal (área social e serviços) e posterior do lote (área íntima). É interceptada pelo caixilho de canto de desenho geométrico executado em madeira e 
vidro que ocupa todo o vão do pé direito e abriga a porta de entrada.
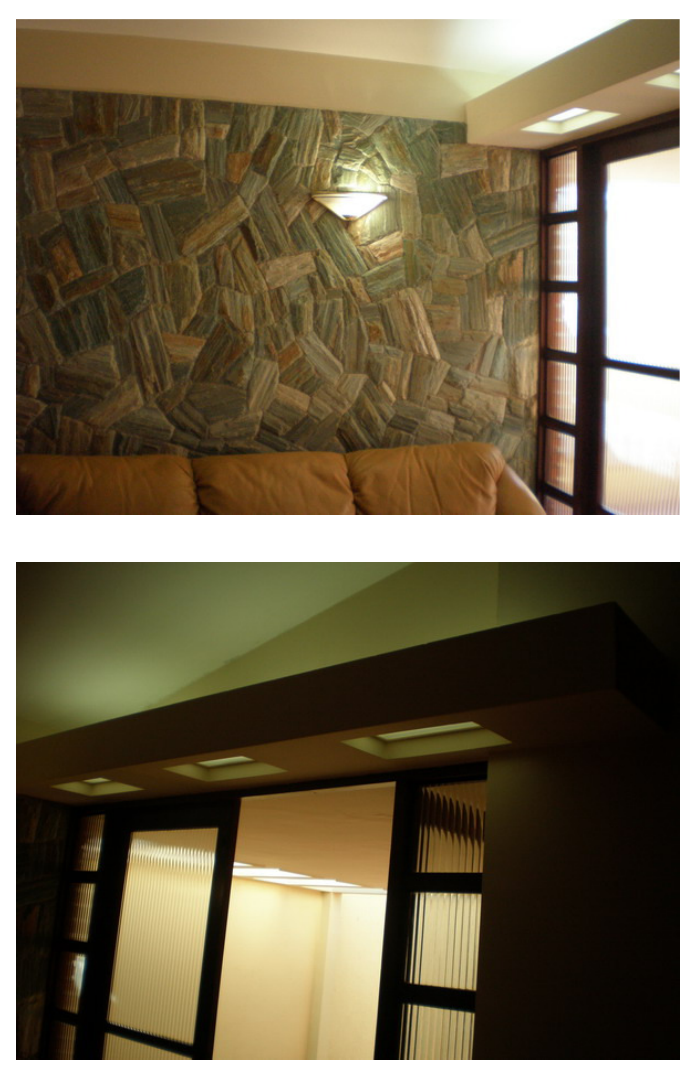

Acima: Detalhes da sanca em gesso. Abaixo: painel geométrico apoiado no volume da lareira. Fotos da autora.

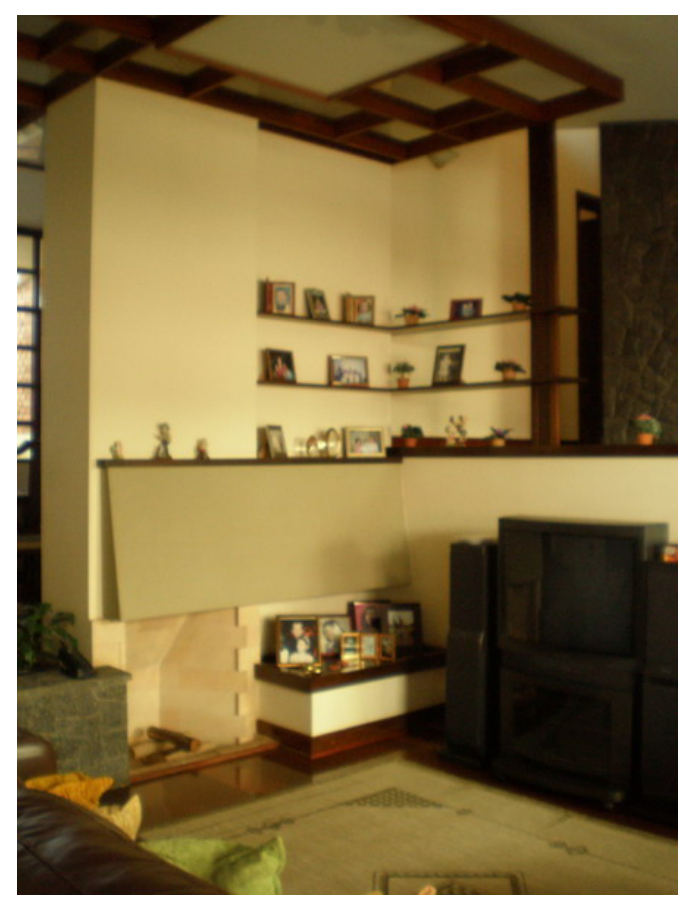

O mesmo desenho se repete no caixilho da sala de jantar permitindo que a luz transpasse a área social de lado a lado. O sentido de diluição dos limites interior e exterior, de continuidade e espaço fluido é marcante e as funções estar e jantar se distinguem apenas por um lance de escada ancorado na lareira central. O volume da chaminé é anteparo para uma estante no nível mais alto. Outras experiências próximas são observadas em arquiteturas paulistas influenciadas por Wright, inclusive em Eduardo de Almeida e nos irmãos Dácio e David Ottoni, ex-integrantes do escritório Horizonte.

Não há um só ponto de luz no teto em toda a casa, eliminando o forro ou a fiação embutida na laje. Todas as luminárias são arandelas ou se encaixam em estruturas projetadas exclusivamente para esse fim, a exemplo do painel geométrico de madeira e vidro leitoso no limite da lareira com a sala de jantar e da sanca que se prolonga na altura da laje externa sobre a porta do escritório.

A estrutura em madeira e vidro sobre a lareira é um dos pontos altos do projeto. O painel horizontal se contrapõe à inclinação da laje de cobertura e se remete aos desenhos geométricos wrightianos. 

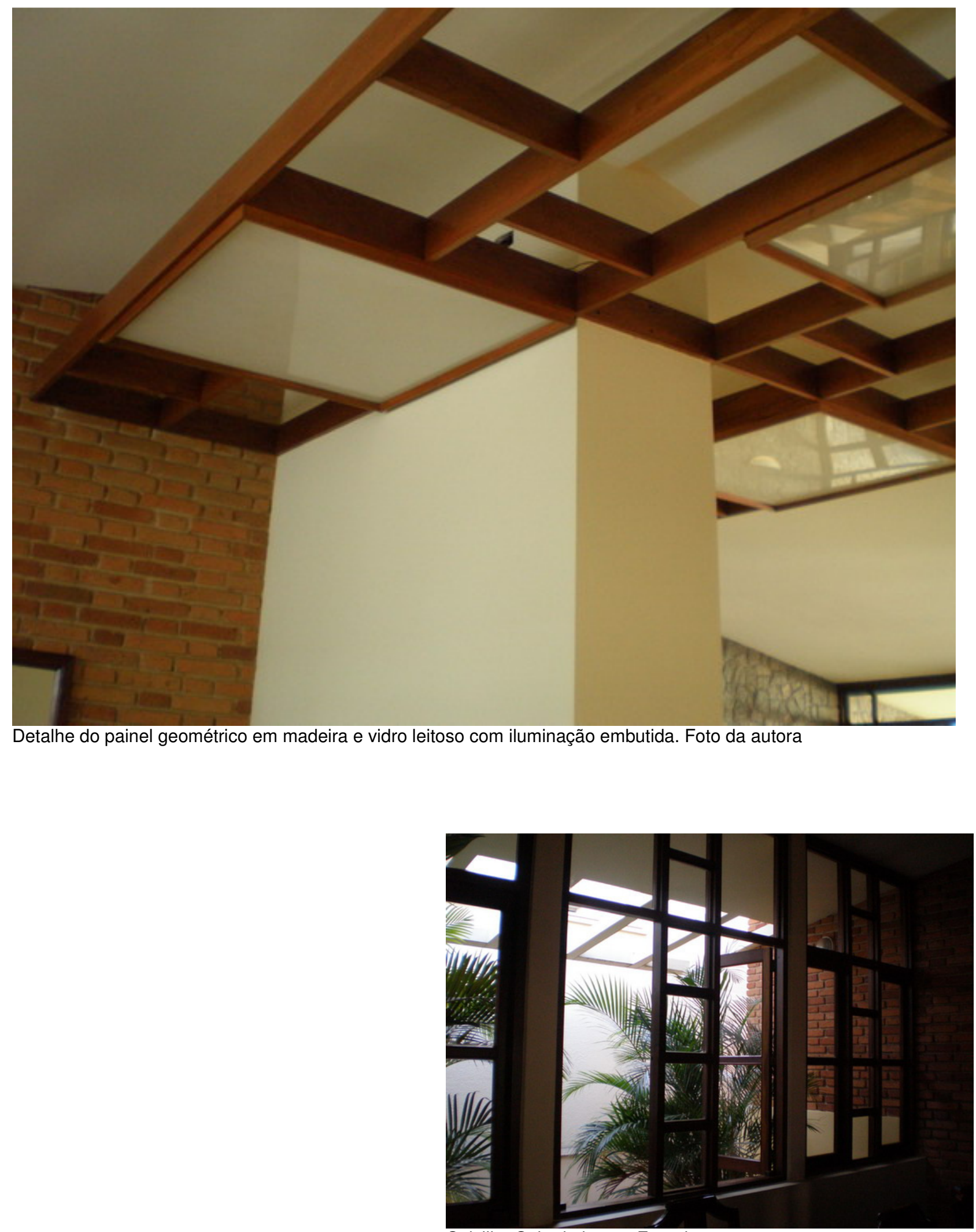

Caixilho Sala de jantar. Foto da autora 

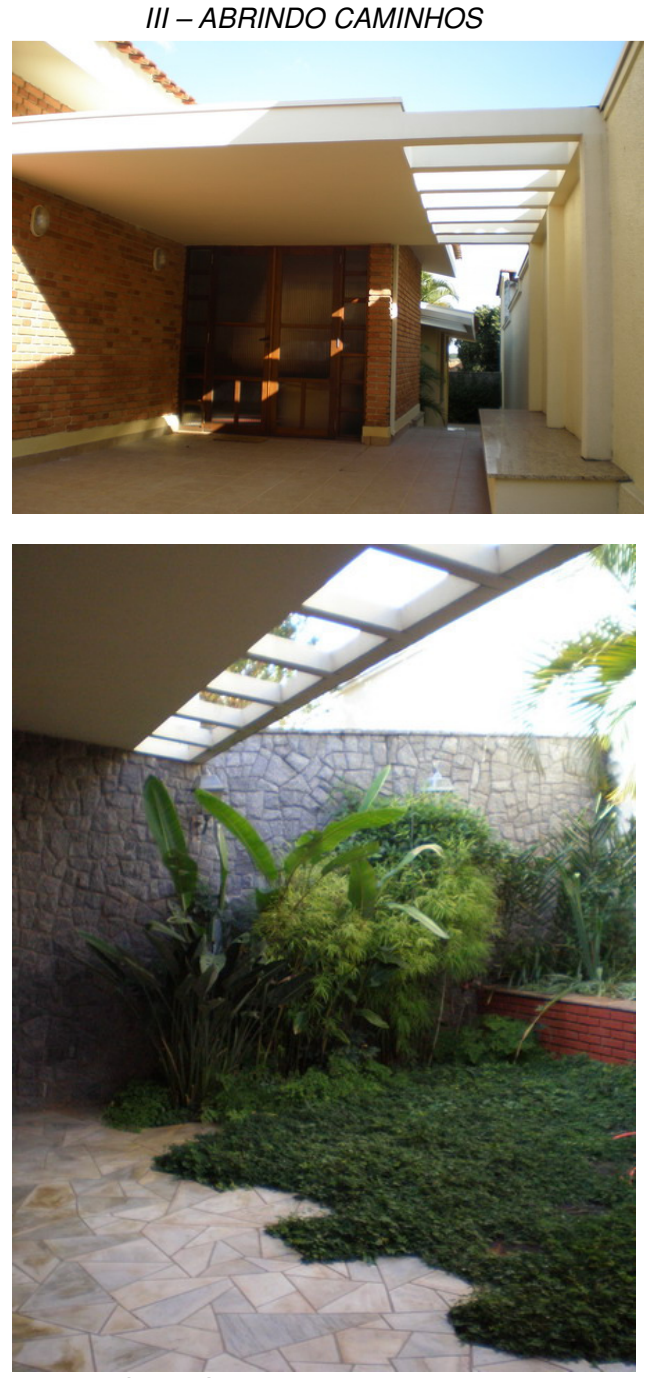

Acima: Casa Senise. Detalhes dos beirais.

Fotos da autora
A casa Senise prima nos detalhes e tira partido de materiais de alta qualidade. Todo serviço de marcenaria foi executado fora da cidade, que não dispunha na época de mão de obra especializada à altura do acabamento desejado. Nota-se aí a dificuldade em materializar uma arquitetura que saía do padrão convencional.

O efeito estético das duas águas que cobrem toda a edificação é marcante logo na entrada, criando pé direito elevado sobre a garagem e sala de estar. A cobertura descarrega esforços nos muros de pedra laterais. A extensão dos beirais resulta em pergolados inclinados. Esses elementos trazem referências aos avanços da cobertura criados por Wright que se projetam sobre os terraços da Avery Coonley (1911-12) e da Malcom Willey House (1933-34). Também são claras referências às experiências obtidas na Georges Sturges House de 1939.

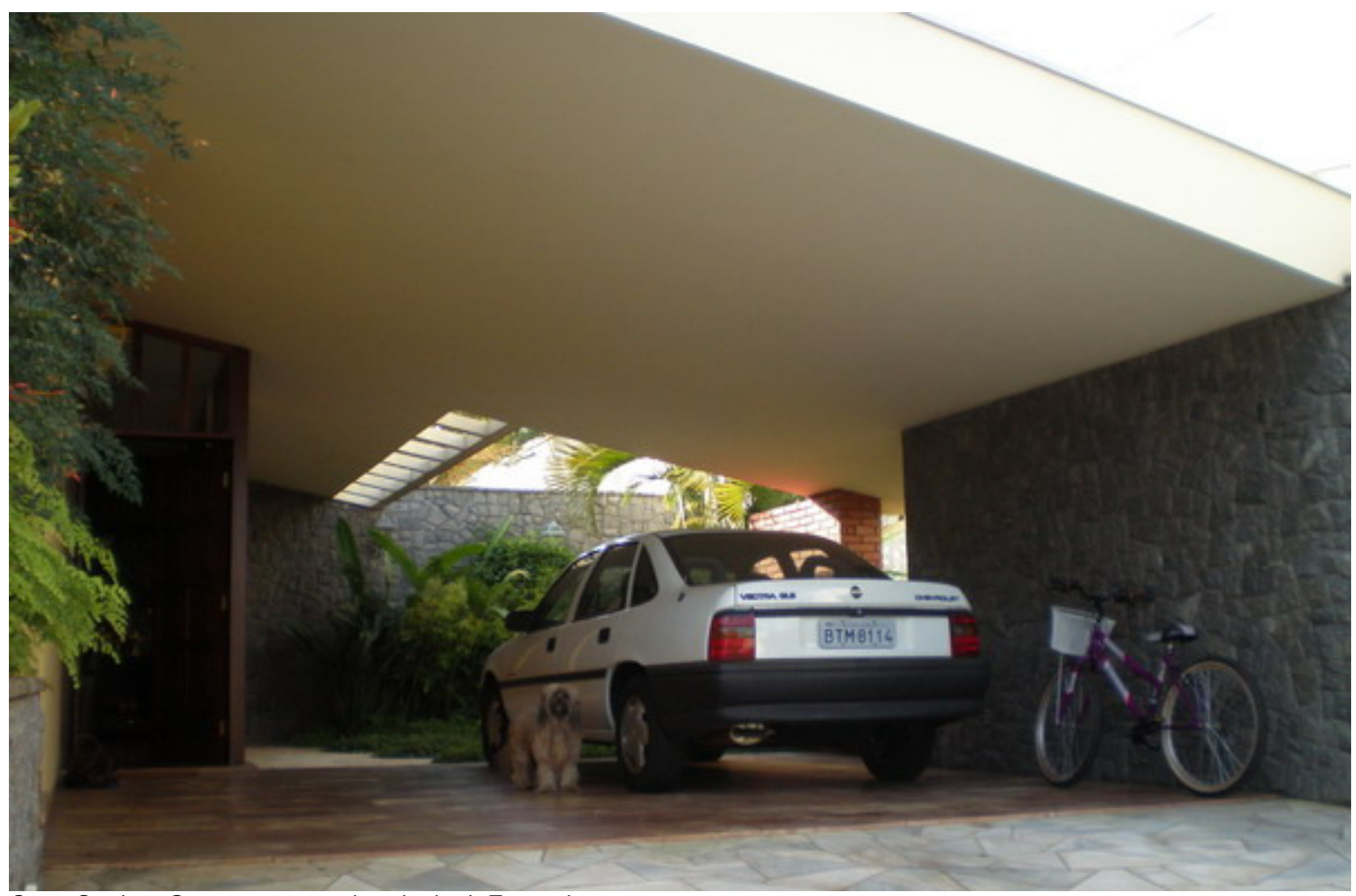




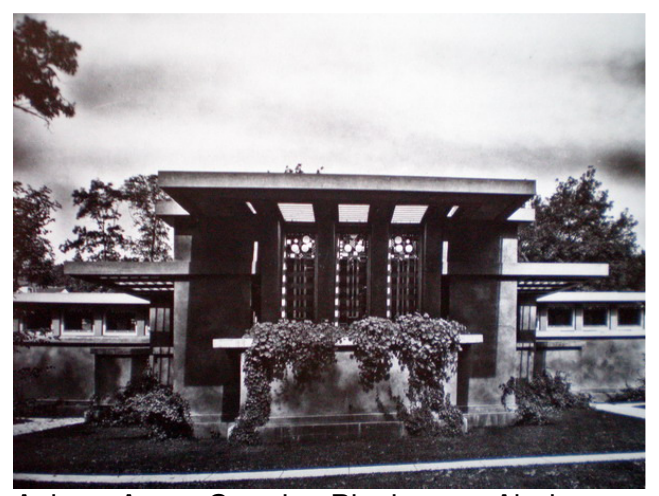

Acima: Avery Coonley Playhouse. Abaixo: Malcom Willey House. Fonte: Pfeiffer(2000) páginas 77 e 117 respectivamente.
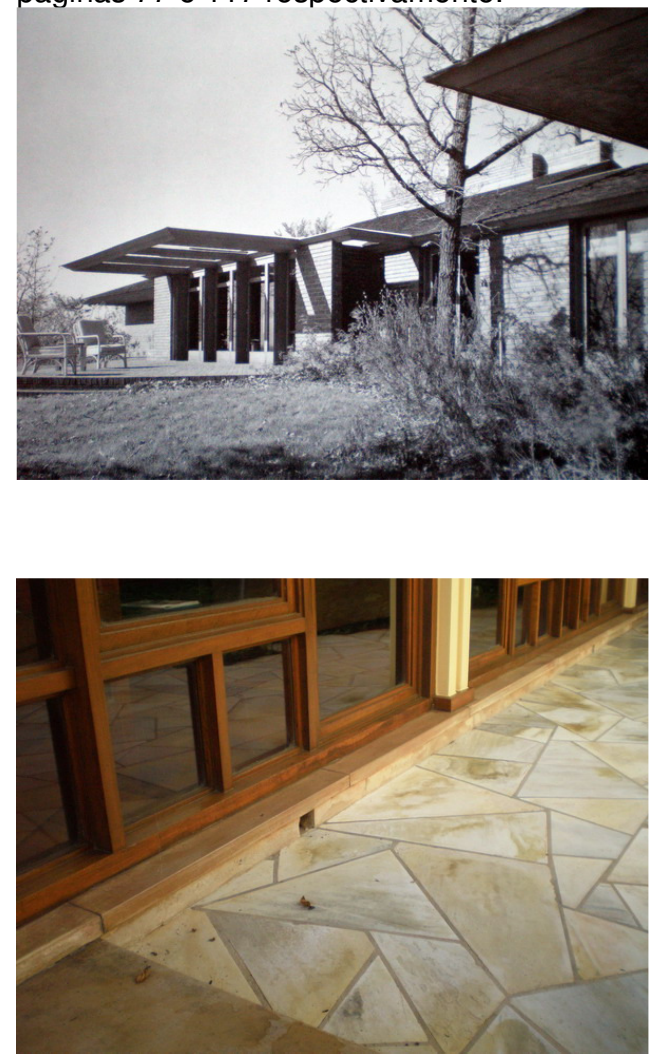

Casa Senise. Acima: Detalhe orifícios no contrapiso. Abaixo: vista interna jardim frontal. Fotos da autora

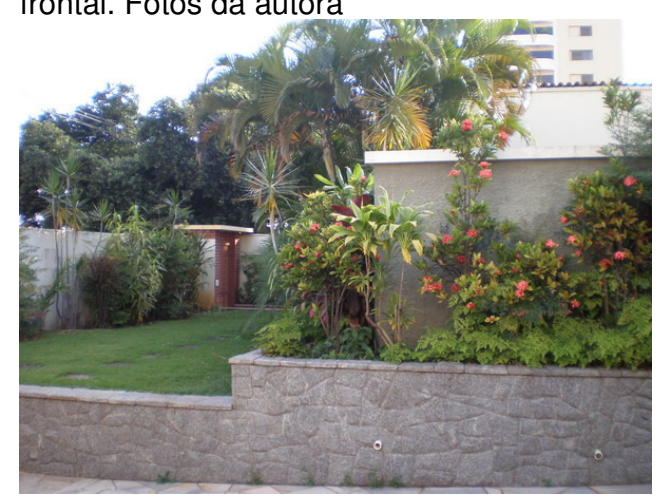

Os beirais vazados já haviam sido usados por Wright anteriormente na George Stwart House de 1909, este que teria sido seu primeiro projeto na Califórnia, e teria sugerido solução similar à Artigas na sua primeira residência (1942) e em projetos posteriores. Também foi idéia adotada pelos irmãos Dácio e David Ottoni nas residências Mário Najm (1964) e Mário F. Braz (1965), ambas construídas em São Paulo e realizações de influência wrightiana.

A casa Senise passou por reformas há alguns anos e ganhou muro alto e portão eletrônico que impedem que seja vista da rua, mas a linguagem e materiais originais estão preservados, a exceção da cozinha onde os armários e bancada em concreto foram removidos.

O piso da sala em madeira é ainda do projeto original e está em excelente estado de conservação apesar de seus 42 anos. O segredo para o bom estado da madeira consiste no assentamento das tábuas como piso flutuante, pois estas não têm contato direto com o contrapiso. Pequenas aberturas protegidas por micro-telas permitem uma ventilação constante e afastam a umidade que vem do solo.

A declividade do terreno não é sentida na implantação. A casa repousa sobre o solo e os desníveis são vencidos por lances de degraus suaves e pequenas escadas ergonomicamente perfeitas em sua execução, uma marca registrada do arquiteto.

O muro à frente do lote suporta uma floreira que vence o desnível da rua. A solução escalonada do jardim acentua a horizontalidade do conjunto. 

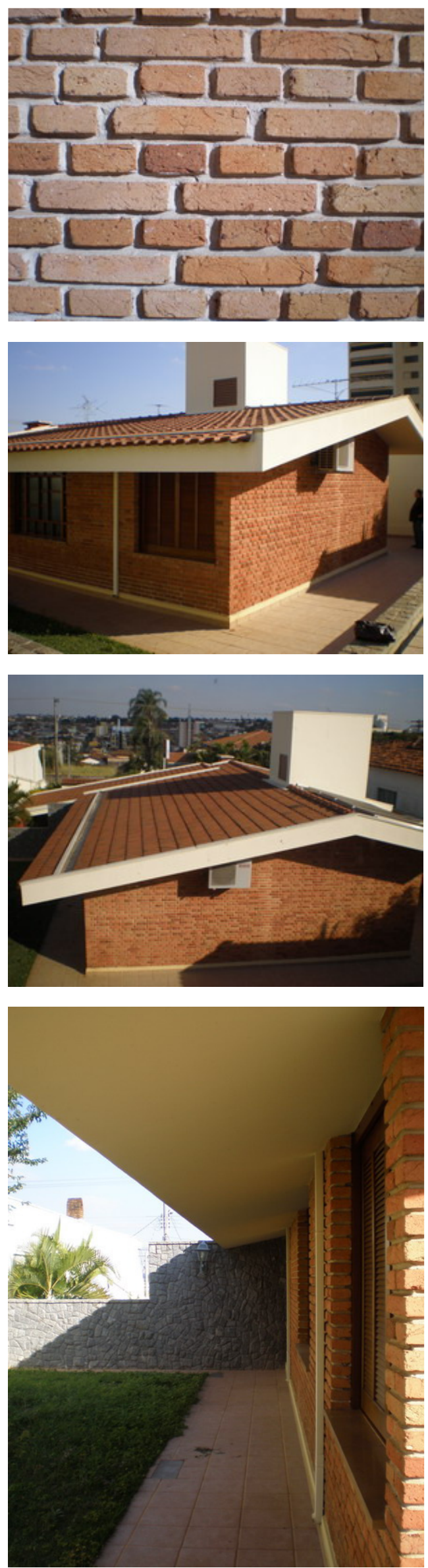

Solução similar Wright havia adotado em muitas de suas praire houses, a exemplo da Dana House (1899-1900), da Darwin Martin (1904-1905) e da Robie House (1906-1909). Há também referências claras nesse projeto de Luiz Gastão à Honeycomb House (1936-37) não apenas na solução do muro baixo escalonado que abriga a floreira, mas nas sancas internas que se prolongam sobre as portas de entrada. Outra floreira lindeira ao muro lateral esconde uma área de servidão e dá sustentação a bancos intercalados entre os jardins e os apoios da cobertura.

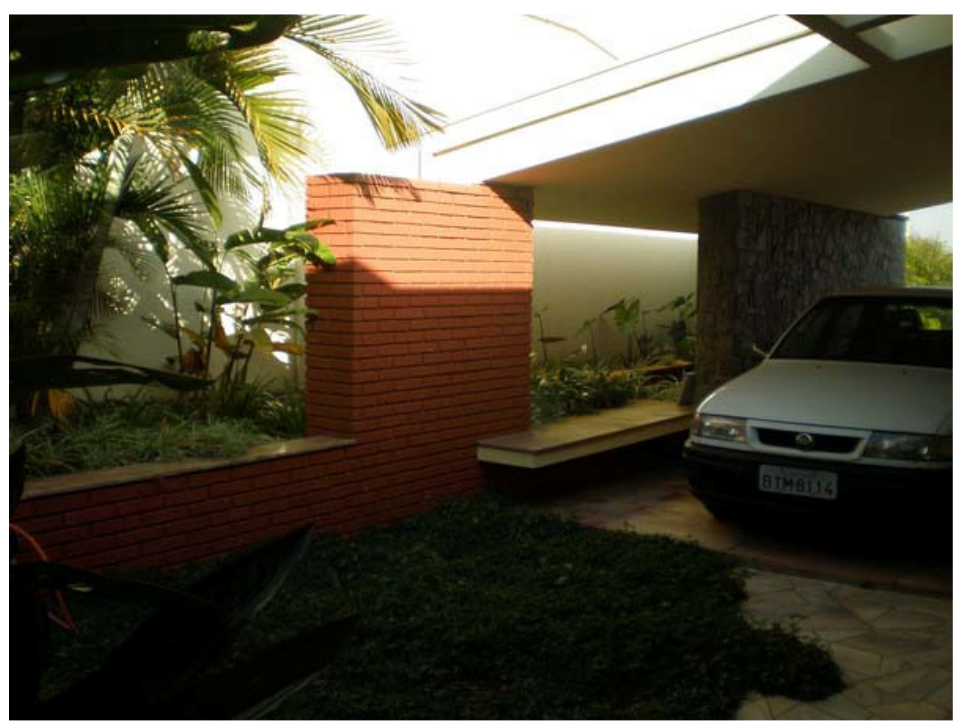

A casa Senise foi uma das primeiras construídas em São Carlos em tijolo aparente. O assentamento incomum tira partido da espessura da parede de um tijolo e meio, intercalando as fiadas em meio tijolo e tijolo inteiro, advém de experiências anteriores desenvolvidas nos edifícios do campus da EESC e será recorrente em projetos futuros. Este arranjo das fiadas intercaladas se remetem ao efeito alcançado por Wright no uso de tons diferenciados de tijolos de forma difusa na Francis Little House (1912-14) e mais linearmente na Malcolm Willey House erguida vinte anos 
depois. As áreas de serviço da casa Senise incorporam os conceitos expostos por Wright nas usonian houses do workplace ou utility core, que englobam cozinha e lavanderia num núcleo único de serviços, ainda que Gastão não adote nesse projeto, o lavabo como integrante desse sistema hidráulico.
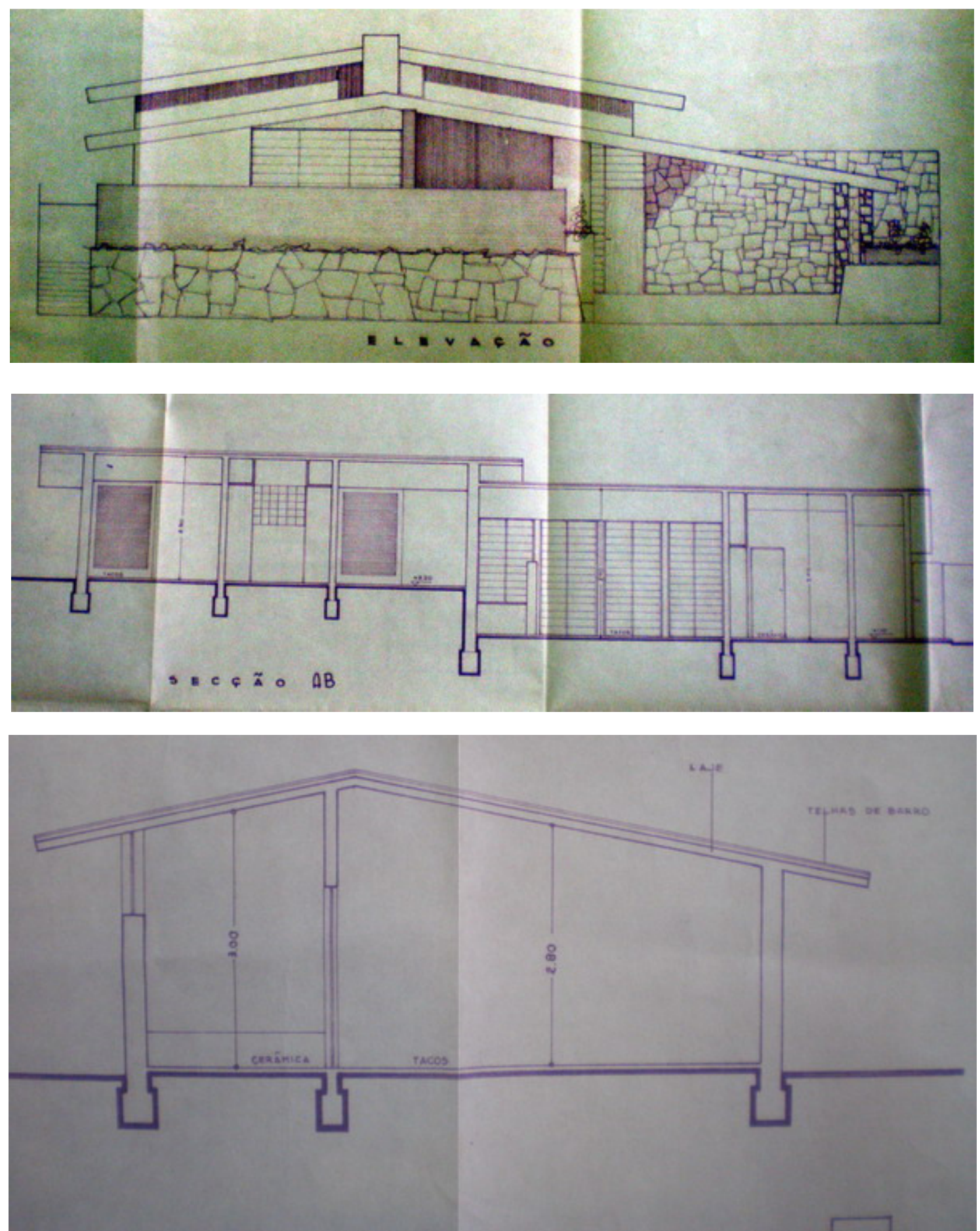

Casa Senise. Cortes e elevação frontal. Desenhos fornecidos pelo atual proprietário. 


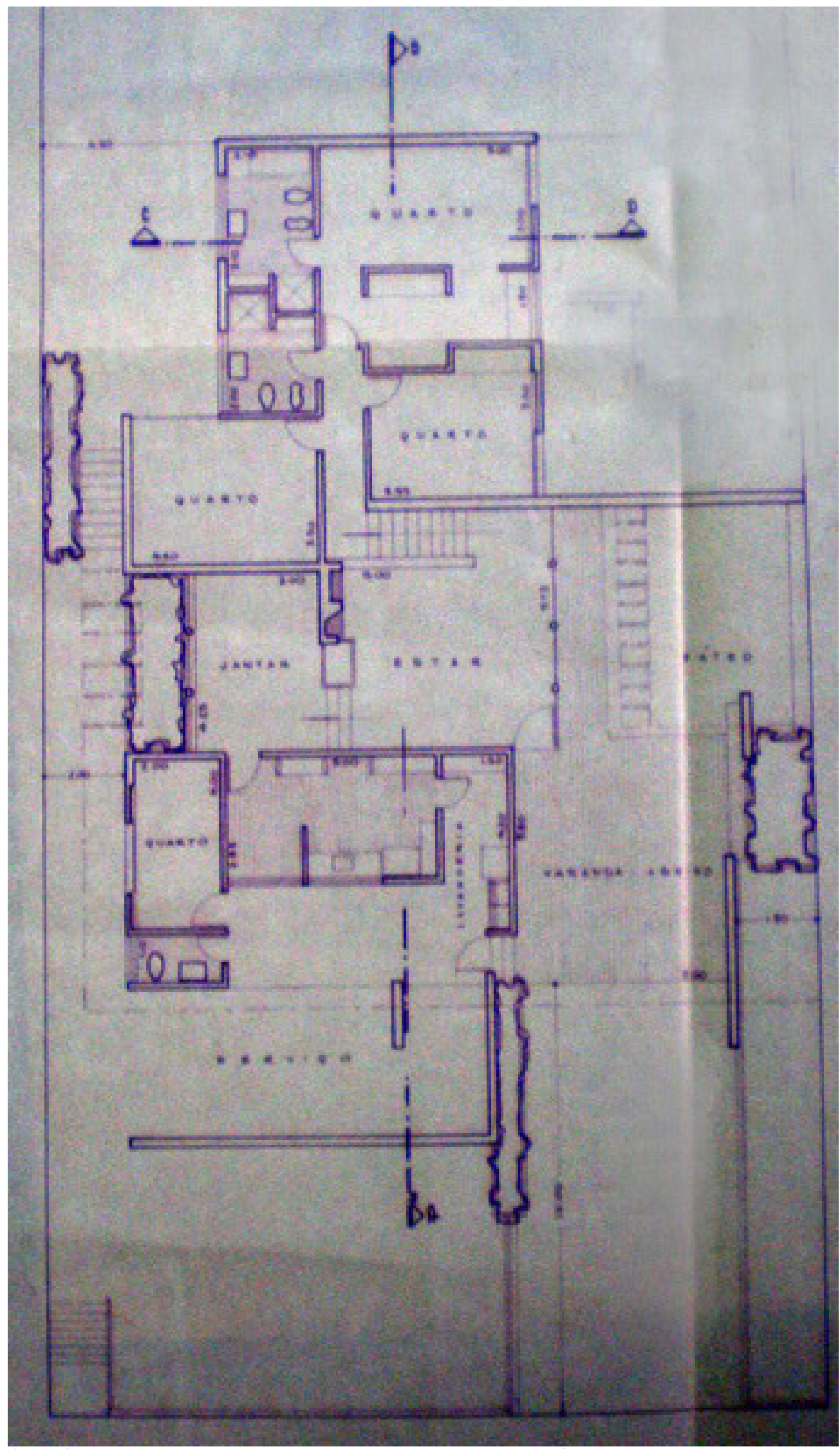

Casa Senise. Planta. Desenhos fornecidos pelo atual proprietário. 
As dependências de empregada, inexistentes na grande maioria das usonian houses, estão presentes nesse projeto, até mesmo por uma tradição brasileira, mas fazem parte do workplace, junto à cozinha e área de serviços. $\mathrm{Na}$ área íntima, armários embutidos separam dormitório e closet.

Datada da mesma época, a residência José Celso Contador, assim como a casa Senise, foi outra das primeiras obras residenciais em tijolo aparente em São Carlos. Contador conta que o "ar rústico" da casa soou de forma estranha aos vizinhos na época.

As pessoas pensavam, fiquei sabendo, que eu estava sem dinheiro para acabar a construção. ${ }^{1}$

Infelizmente, pouco restou do projeto original. O piso originalmente em concreto queimado recebeu revestimento cerâmico. Sobre o tijolo aparente foi aplicado reboco e pintura ou revestimento em pedra. Segundo Contador, as paredes da sala em tijolo à vista, apresentavam uma composição de grande efeito estético, resultado do uso de meio tijolo, tijolo inteiro e um tijolo e meio, com inúmeras e diversificadas combinações.

Implantado em lote de medidas reduzidas, 0 projeto eliminou qualquer tipo de corredor, condensando toda a circulação na parte central. Medida que Wright certamente aprovaria, pois este se referia a corredores como "espaços mortos".

O volume dos boxes dos banheiros formavam duas conchas em concreto projetadas para além do corpo da casa, solução recorrente na

\footnotetext{
${ }^{1}$ José Celso Contador em depoimento à autora em 19 de outubro de 2007
} 
residência do arquiteto (1974). No quarto do casal, assim como na casa Senise, o próprio armário divide dormitório e closet.

$\mathrm{Na}$ cozinha, armários e bancadas foram executados em concreto revestido com epóxi, mas esta não teria sido uma experiência bem sucedida, dada à suscetibilidade do epóxi que não resistia ao atrito e lascava facilmente com metais.

Data do mesmo período, o projeto para a Igreja de Vila Pureza, único de cunho religioso atribuído ao arquiteto, que como muitos outros, foi feito sem cobrança de honorários. Gastão tinha o hábito -contam os amigos- de esboçar desenhos sobre pequenas folhas de papel de forma despojada, até mesmo em mesas de bares, dando soluções de projeto a questões levantadas em conversas informais. Muitas vezes, realizou projetos completos sem cobrar nada por seu trabalho. 

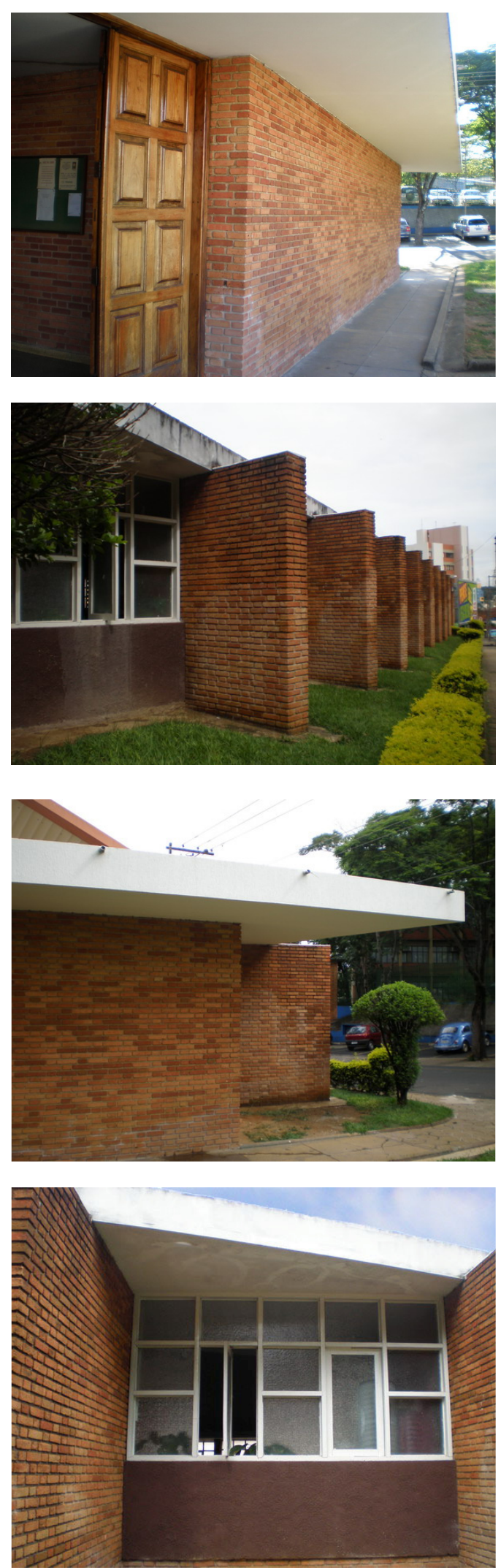

Igreja N. S.de Fátima. São Carlos. Vistas externas. Fonte: fotos da autora

\section{Igreja de Vila Pureza}

O projeto da igreja Nossa Senhora de Fátima elaborado em 66 foi doado pelo arquiteto à Paróquia de Vila Pureza, em São Carlos.

A obra concluída em 1970, teria sido viabilizada através da colaboração de pessoas de posses da cidade.

Implantada na bifurcação da Avenida Miguel Petroni, busca não estabelecer com a rua contato algum. Resguarda o espaço interno do ruído e do movimento externo, propiciando o silêncio desejável para o fim a que se propõe. Famosa por sua acústica privilegiada, se não se isola por completo do meio urbano, retira dele uma luz difusa através de aberturas laterais que chegam até a laje perimetral onde se apóia a cobertura. Assim como nos anfiteatros da EESC, a modulação estrutural é marcante, encaixando os caixilhos entre os planos seqüenciais em alvenaria de tijolos.

$\mathrm{O}$ isolamento acústico é em parte alcançado por esta seqüência de planos de parede espessa, com $35 \mathrm{~cm}$ de largura, presente nas duas laterais.

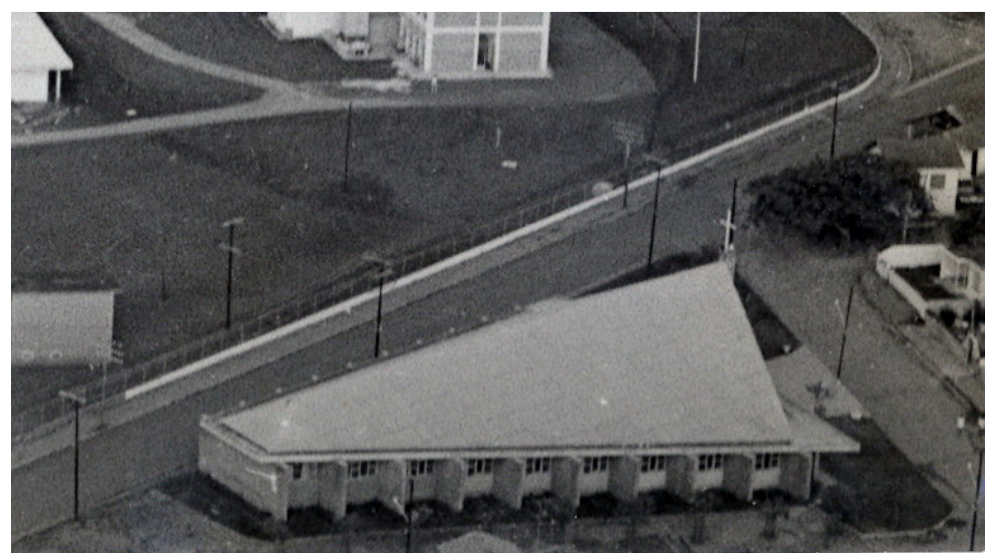

Igreja N.S. de Fátima em 1974. Fonte: Fundusp 


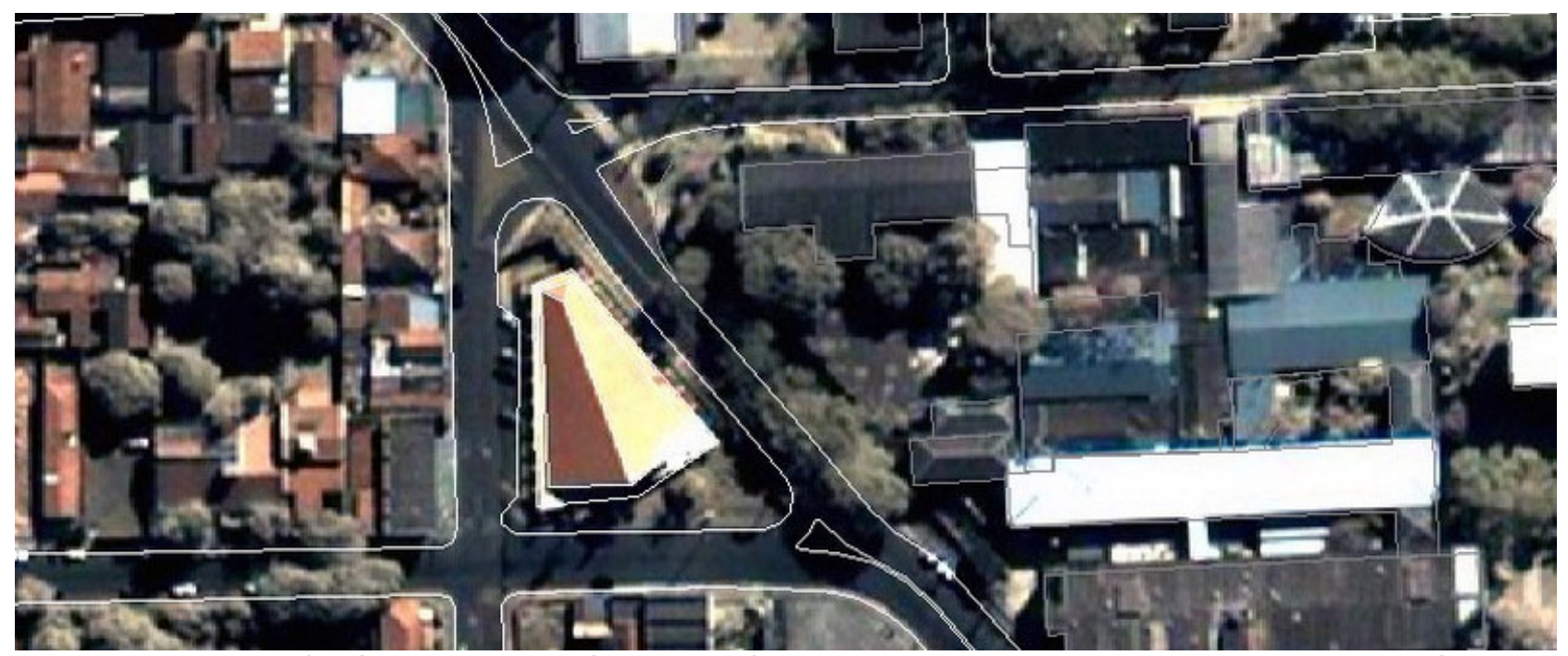

Implantação Igreja N. S. Fátima. Foto de satélite. Fonte: Google Earth 2006. Nota-se curiosamente nesta foto, à direita e acima, um dos anfiteatros da EESC com a cobertura em cinco águas, resultante da reforma desastrosa que substituiu a primeira cobertura e escondeu o beiral do projeto original.

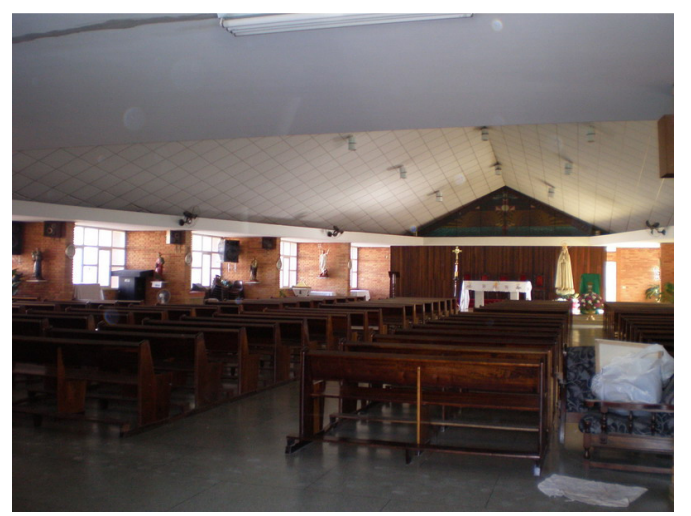

Igreja N. S. Fátima. Vista interna da nave e detalhe da escada em granilite. Fonte: fotos da autora

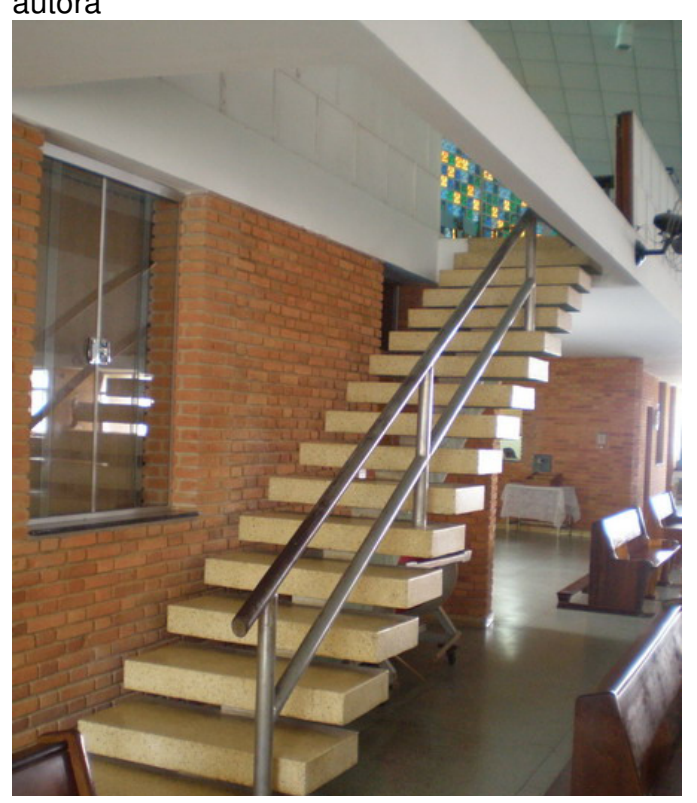

A implantação se remete à forma triangular do terreno, mas não se rende a suas inclinações. Vence, num primeiro instante, o declive natural da rua por meio de floreiras locadas no limite entre a calçada e a edificação, no que dialoga com as praire houses wrightianas.

A igreja estabelece uma ordem estrutural seqüencial de planos executados em alvenarias de um tijolo e meio, nas palavras do próprio arquiteto, como "algo preso à terra". ${ }^{2}$

Sólidos, pesados, estes planos se repetem nas laterais seguindo uma modulação de $3,40 \mathrm{~m}$.

Pensada inicialmente com nove módulos (formados cada um, por um par de planos) durante a obra ganhou um módulo a mais.

Sobre os planos maciços em tijolo aparente, repousa uma laje de 4 metros de largura que intercepta o volume no limite entre interior e exterior, percorrendo todo o perímetro. Nada delgada, a laje é tão pesada como os planos que a

\footnotetext{
${ }^{2}$ Gastão faz referência à Igreja em aula dada na EESC, e a qualifica como algo pesado, preso ao chão. Ver LIMA (199?)
} 


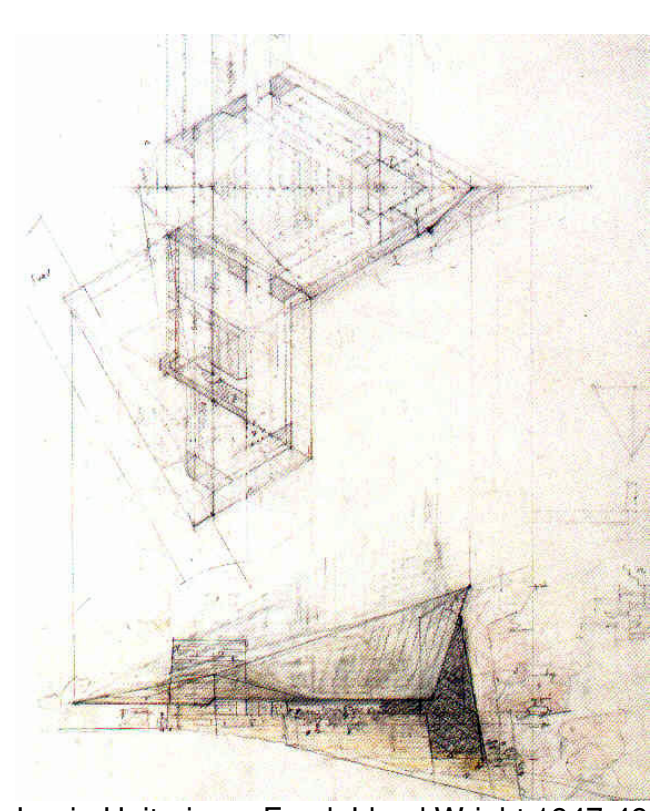

Igreja Unitariana. Frank Lloyd Wright 1947-49 Fonte: Pfeiffer(2000). Pg 159

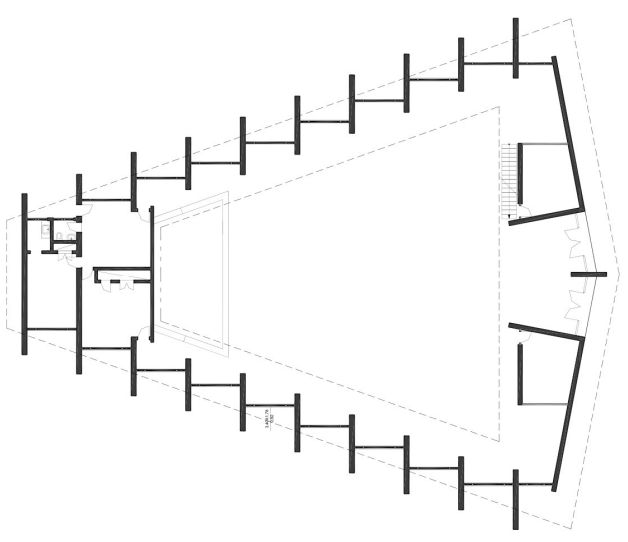

Igreja Nossa Senhora de Fátima. Planta baixa e elevação. Desenhos feitos por ocasião da elaboração de projeto luminotécnico pelo escritório de arquitetura Design Monteg em 2006.

Fonte: desenhos cedidos por Geraldo Fernandes. suportam. Na parte frontal da nave, a laje se alarga para formar o coro da igreja e na parte posterior ao altar, para cobrir a sacristia. Essa laje exerce dupla função, encobrindo a calha que recebe a água da cobertura na parte externa, e escondendo a fiação elétrica na parte interna. Gastão já havia lançado mão deste recurso na biblioteca da ESALQ (1964). Também é possível encontrar solução semelhante em Wright, na Robie House (1906-09) e na Honeycomb house (1936-37).

Essa laje que intercepta o volume se destaca pela cor branca que contrasta com o tom terra do tijolo aparente. A tomada de partido desse contraste, assim como o uso do tijolo à vista são presenças constantes em outros projetos de Luiz Gastão, anteriores e posteriores à Igreja. Também é recorrente em seus projetos, uma linha densa horizontal que intercepta o volume, seccionando-o em um plano inferior e um superior, ainda que a edificação tenha um pavimento único. Essa linha, geralmente representada por uma viga-calha, oferece guarida à entrada do edifício numa tentativa gestual de ganhar sua horizontalidade.

O triângulo que se forma sobre o altar era aberto inicialmente, prolongando a visão do forro sobre a sacristia. Foi fechado em momento posterior por um painel com motivos religiosos.

A escada que dá acesso ao coro, executada em granilite, é solta da alvenaria e se estrutura a partir de uma viga central. Esse princípio estrutural é recorrente em outras escadas e rampas projetadas pelo arquiteto. $^{3}$

O projeto original previa duas ante-salas logo na entrada da nave, abrigando a sala paroquial e a

\footnotetext{
${ }^{3}$ Como é o caso da escada da casa do arquiteto, da escada do São Carlos Clube e da rampa de acesso à Biblioteca Central da ESALQ
} 

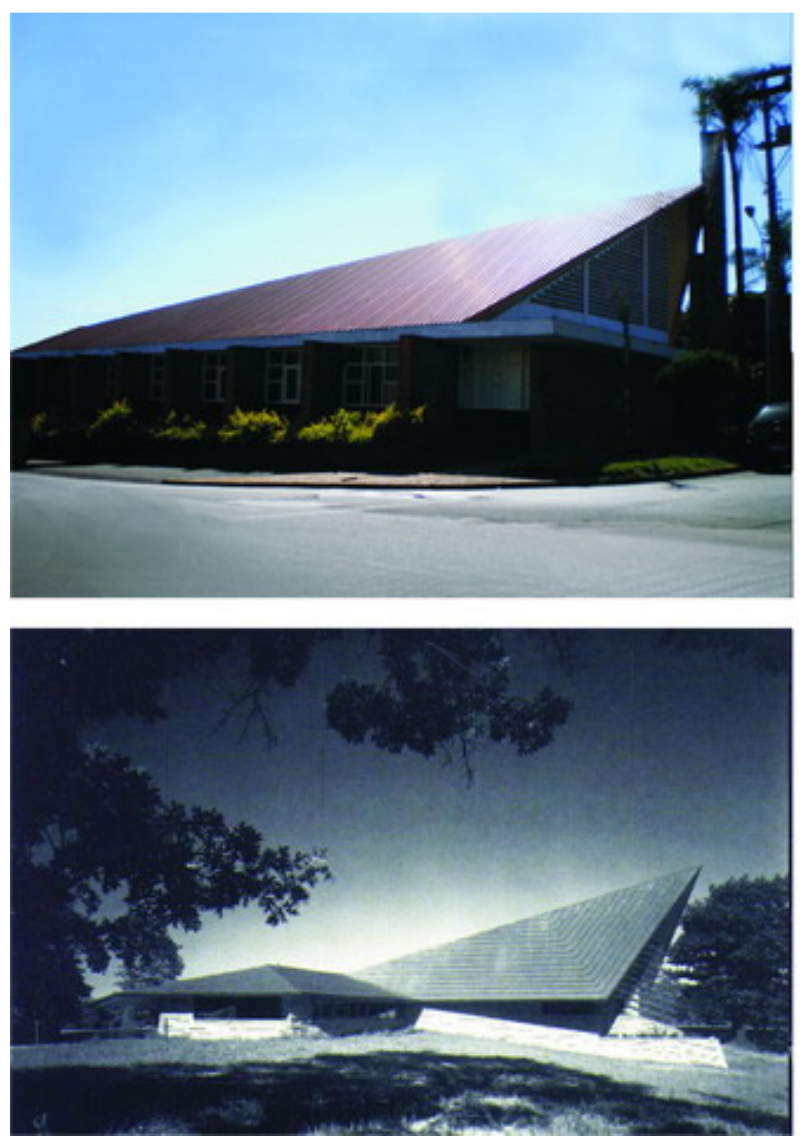

Acima: Igreja N. S. de Fátima e Unitarian Church. Vistas laterais. Fonte: N. S. de Fátima: fotos da autora. Unitarian Church: Pfeiffer (2000). Pg 158

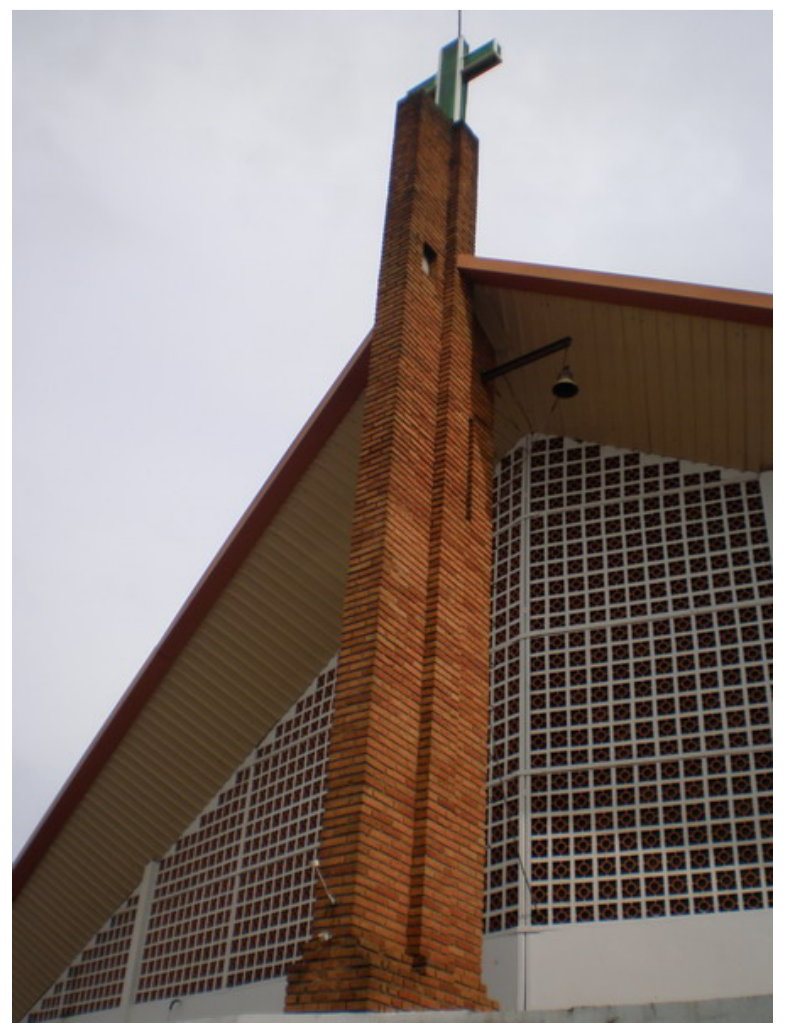

Igreja N. S. de Fátima. Detalhe do campanário. Foto da autora. secretaria. A ala posterior ao altar abrigava a sacristia e a sala do padre, com copa e um sanitário. Mudanças na estruturação da Igreja Católica resultaram em reformas internas, porém estas foram feitas no sentido de não descaracterizar a volumetria nem a concepção do partido adotado. Consistiu essa reforma em criar uma sala para o santíssimo, que antes ficava junto ao altar na nave principal. Também foram construídos sanitários e um trocador para crianças, respeitando o uso dos materiais adotados por Luiz Gastão e mantendo a integridade do partido inicial.

Muitas imagens foram atribuídas à forma de sua cobertura, que para alguns se assemelha ao manto de Nossa Senhora. Também ouvimos inúmeros comentários sobre a idéia de que a Igreja seria uma reprodução estilizada de uma nau portuguesa, tendo seus remos marcados pela seqüência dos planos em tijolo aparente e a vela redesenhada pela cobertura, presa ao mastro do campanário. Acreditamos que estas foram imagens originárias da criatividade e do desejo de encontrar uma explicação mítica para a edificação.

O elemento vazado que cobre a frente da igreja não data da construção original. Inicialmente, o fechamento se dava por meio de telhas plásticas esverdeadas, mas dadas às circunstâncias financeiras com que se desenvolveu a obra, essa teria sido uma medida provisória e paliativa. É bem possível que já houvesse a intenção de se constituir ali um vitral. Relatos de pessoas envolvidas no processo inicial revelam que os vidros coloridos já haviam sido doados antes mesmo da conclusão da 

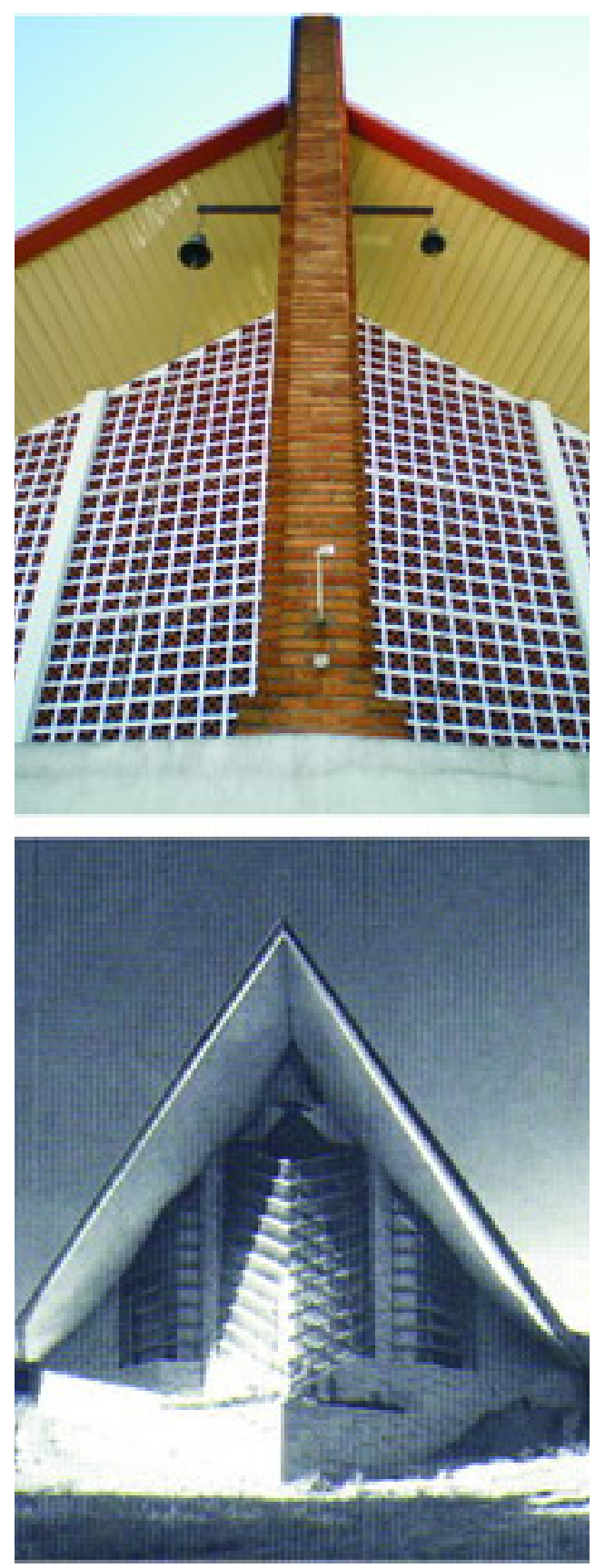

Abaixo: Igreja N. S. de Fátima e Unitarian Church. Vistas frontais. Fonte: N. S. de Fátima: fotos da autora. Unitarian Church: Pfeiffer (2000). Pg 158

Ao lado: Igreja N. S. Fátima. Vista lateral. Seqüência estrutural e floreiras. Na página seguinte: vistas frontais. Fotos da autora obra. A cobertura metálica também substituiu recentemente as telhas originais de fibrocimento.

É visível a referência que a igreja de Vila Pureza faz ao templo unitariano de Shorewood Hills, em Wisconsin, projetado por Frank Lloyd Wright em 1947.

A expressão formal que as duas obras assumem as aproxima esteticamente. A igreja unitariana encerra em si a forma triangular e é igualmente envolvida por uma floreira que a circunda. Por ter plano triangular, assim como em Vila Pureza, rebate a mesma forma geométrica na cobertura.

A Igreja Nossa Senhora de Fátima parece estabelecer com o templo wrightiano mais que um diálogo, uma identidade formal. Wright rompe no projeto da Unitarian Church de Wisconsin, com a idéia da caixa esguia, abolindo o campanário e o pátio frontal clássicos, comuns nas construções religiosas da época nos Estados Unidos.

A supressão do campanário é o elemento que difere o templo de Wright da Igreja projetada por Gastão. Componente indispensável das construções católicas, teria sido suprimido mais facilmente por Wright no templo unitariano.

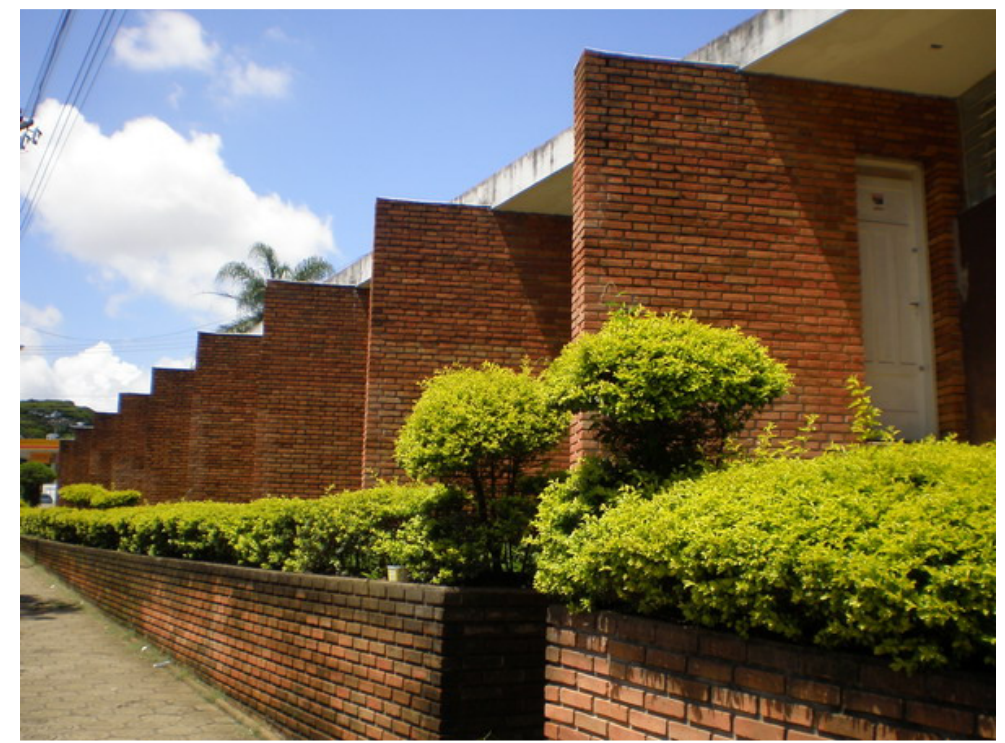




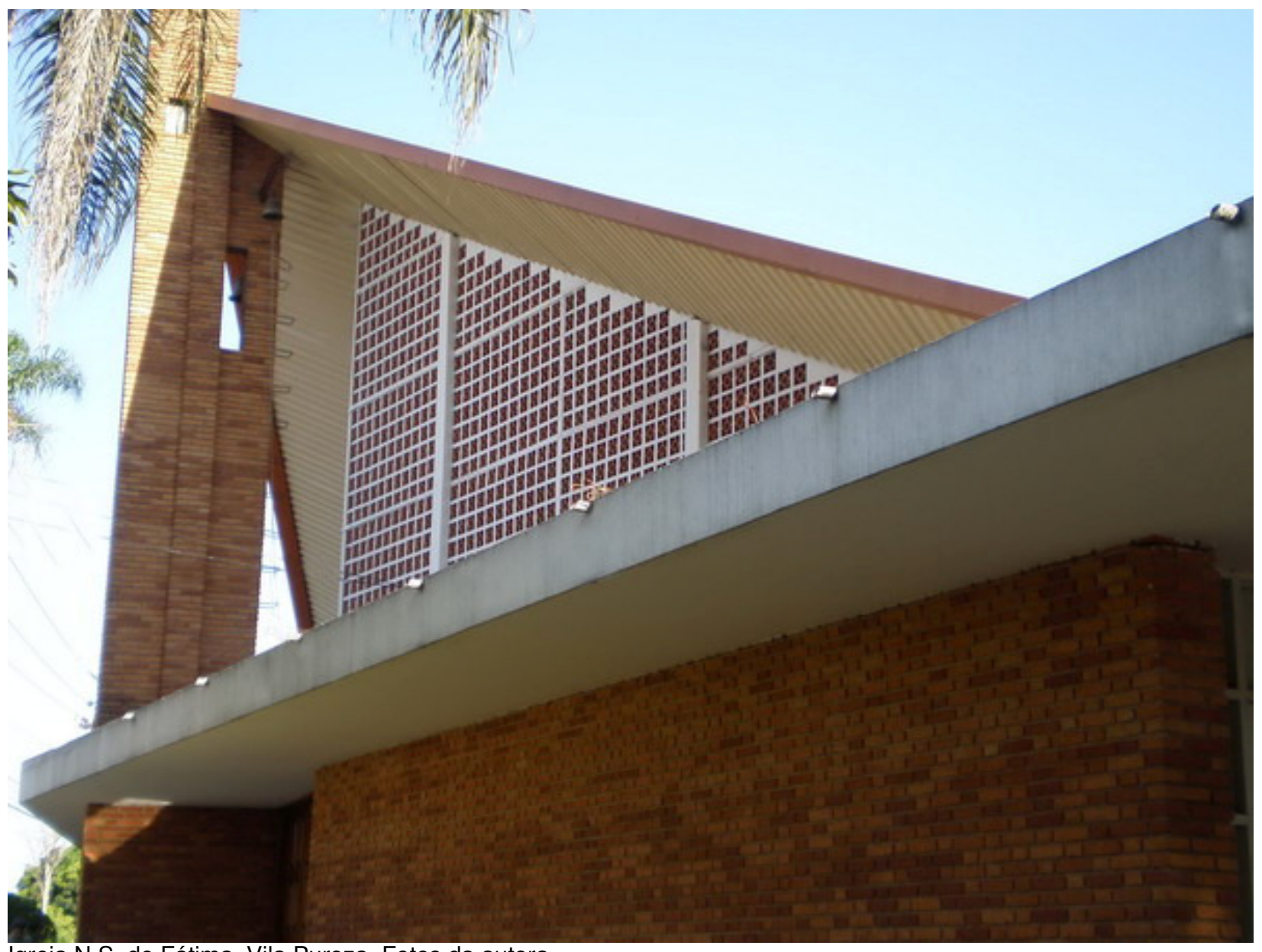

Igreja N.S. de Fátima. Vila Pureza. Fotos da autora.

A Igreja de Vila Pureza inaugura uma seqüência de projetos que Gastão viria a desenvolver nos anos seguintes. Alguns de forma independente, outros ligados à empresa Línea, sociedade que não teria vida longa.

Entre os projetos em parceria se destaca o São Carlos Clube. 
São Carlos Clube: Sede Social

Por necessidade advinda da contratação do arquiteto para o projeto do São Carlos Clube, foi constituída a Línea Arquitetura e Urbanismo S/C Ltda, empresa que Gastão manteve durante alguns anos, em sociedade com outros professores da EESC-USP. A boa parte deles tinha vínculos exclusivos com a Instituição e dedicava tempo restrito às atividades de projeto. Dentre eles, Admir Basso, Ricardo Martucci e Itamar Amador.

O projeto para a sede social do São Carlos Clube se diferencia plasticamente dos projetos anteriores e incorpora uma expressão mais austera de referência brutalista. No entanto, numa observação mais atenta, vê-se que a proposta se mantém fiel aos princípios orgânicos, defendidos até então.

O próprio arquiteto relata os caminhos percorridos durante o processo projetual até a proposta final, à medida que ilustra o descarte das primeiras idéias:

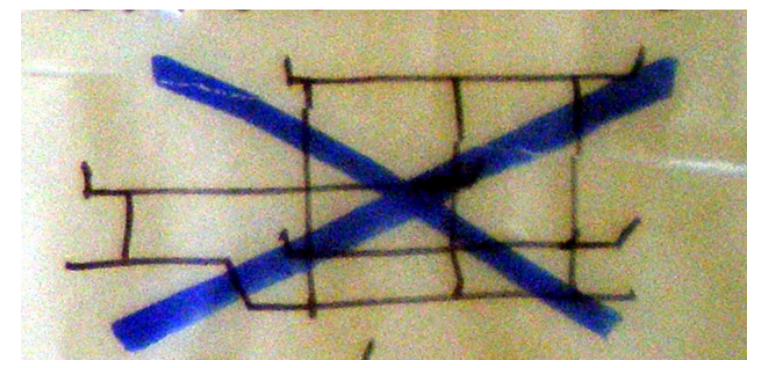

O partido arquitetônico adotado para a sede social do São Carlos Clube seguiu desde o princípio a determinação básica de uma organização espacial e dinâmica, informal e rica em proposta.

Inicialmente pensou-se em planos lineares, procurando insistentemente o conceito acima, o espaço final seria livre e descontraído, porém esbarrava-se na rigidez bruta do processo construtivo.

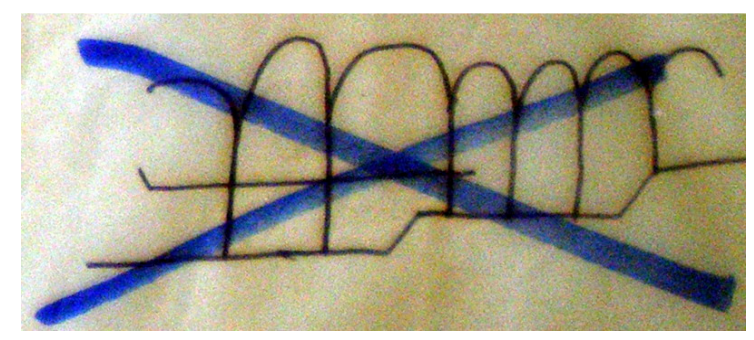

Deixada de lado esta proposta -inviável tecnologicamente- pensou-se em espaços abertos acoplados a um projeto monumental. Esta idéia mostrou-se inviável pela gratuidade da proposta, onde 
seria - a obra - bela apenas aos olhos, ficando o homem delegado apenas como mero expectador.

Descartadas as duas primeiras hipóteses, a terceira idéia acatada como idéia final, tem características mais próximas da organicidade que rege o conjunto de sua obra.

O projeto proposto segue a determinação de que a obra tem como "dever" propiciar a fruição total de seus espaços pelas pessoas que utilizam. Desta maneira procurou-se delinear uma implantação livre e aberta sobre o chão, trazendo o informal rico e dinâmico do espaço circundante para dentro da sede social, numa identificação completa de todo o ambiente propiciando dessa maneira o uso e consumo soberano de todo o conjunto pelas pessoas. $^{4}$

O projeto apresentado à diretoria do clube contava com o programa distribuído em quatro instantes, setorizados em atividades distintas: administração, salão de festas, convivência e auditório. Esse último não chegou a ser construído.

Embora se constitua como um bloco maciço e representativo em escala, a construção não representa um obstáculo. O prédio é permeável não apenas no aspecto visual, mas físico, na transposição dos ambientes nos três níveis. A fluidez espacial presente nas obras anteriores ganha corpo e novas dimensões no projeto do São Carlos Clube. Os espaços conseguem atingir a integração com o entorno circundante, ao mesmo tempo em que definem de forma clara seus próprios limites. 
Es's concitor provicionaram o pactido arquitetovico, que agora \& apresenta un istudo meliuinar, que nostra al persoulalidade da dra proprosta, paial auálise e distas.

- matido arquittonico bi definido funto cou o partido estutural, seguiudo a mesula linguageu, dinâkuica c. descoutraida, abrigando o desurofarinento das afivida. des, atraves de vula nolucāo coerente cour a tecudogia da coustrusāo. Saso arcos modulados en 6,00 metros finto con plawos e racadas, defiuidos nulas funsôs que suprotaräo, e por una viabilidade' tecnica cous-
trutiva.

Nivta menoria estāo conrubstauciados as couccitos de adeue de coucepcoio arquiterica, sequedo os parauetros mais fortes da maitica da mojeceso a quiterica on rya, o poduto fical desta mática i wue obra gerada pri idvias, que mocurau coucebu aubieutes

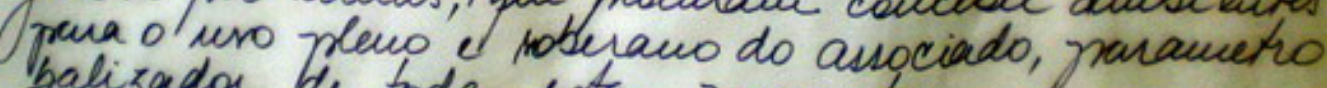
balizada de toda inta momsta.
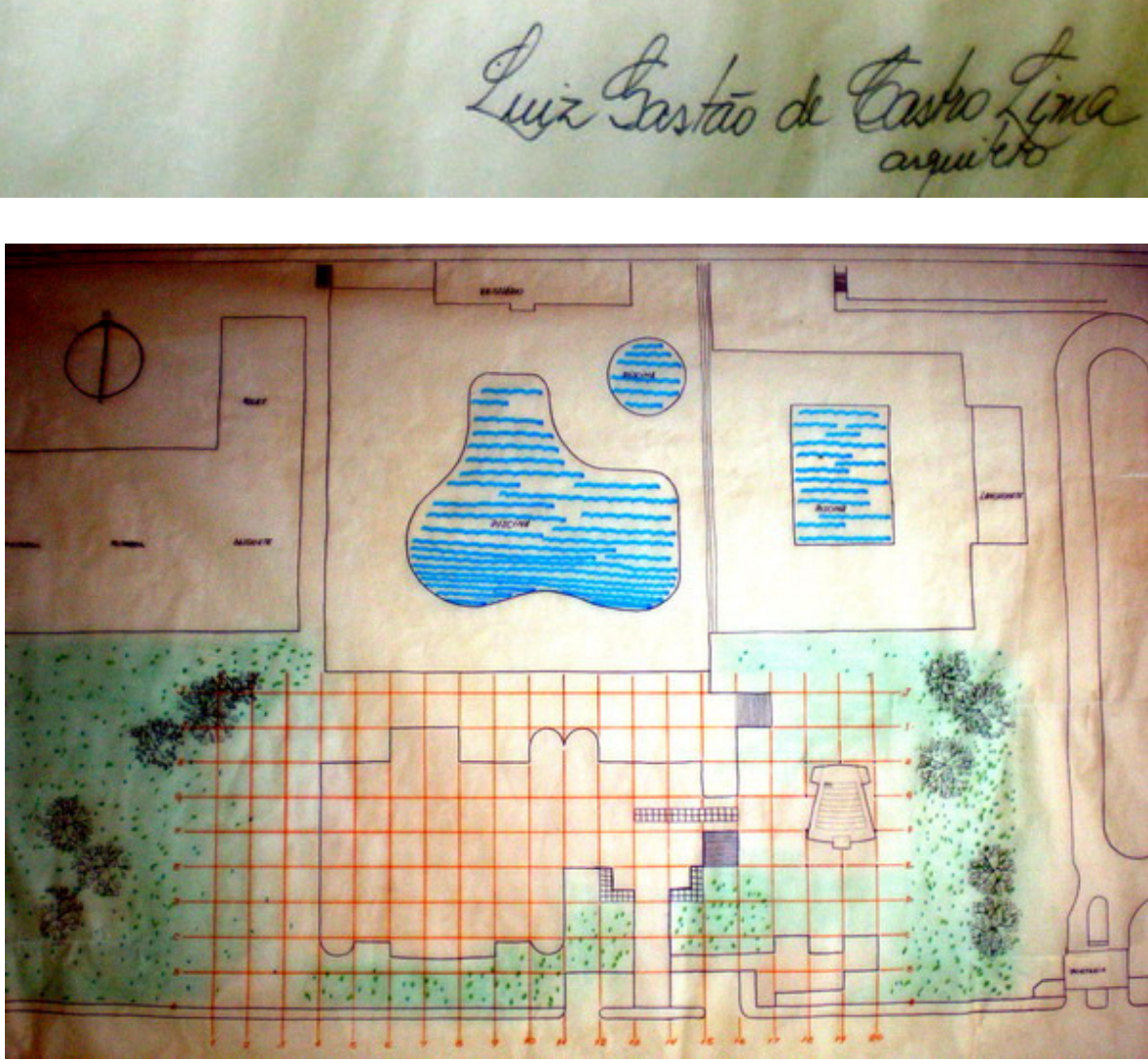

Parte do memorial e croqui apresentados como primeira proposta para o projeto. Fonte: Acervo S. C. Clube

${ }^{4}$ Trecho extraído de uma das pranchas do estudo preliminar para a Sede do S.Carlos Clube, assinadas por Gastão. 

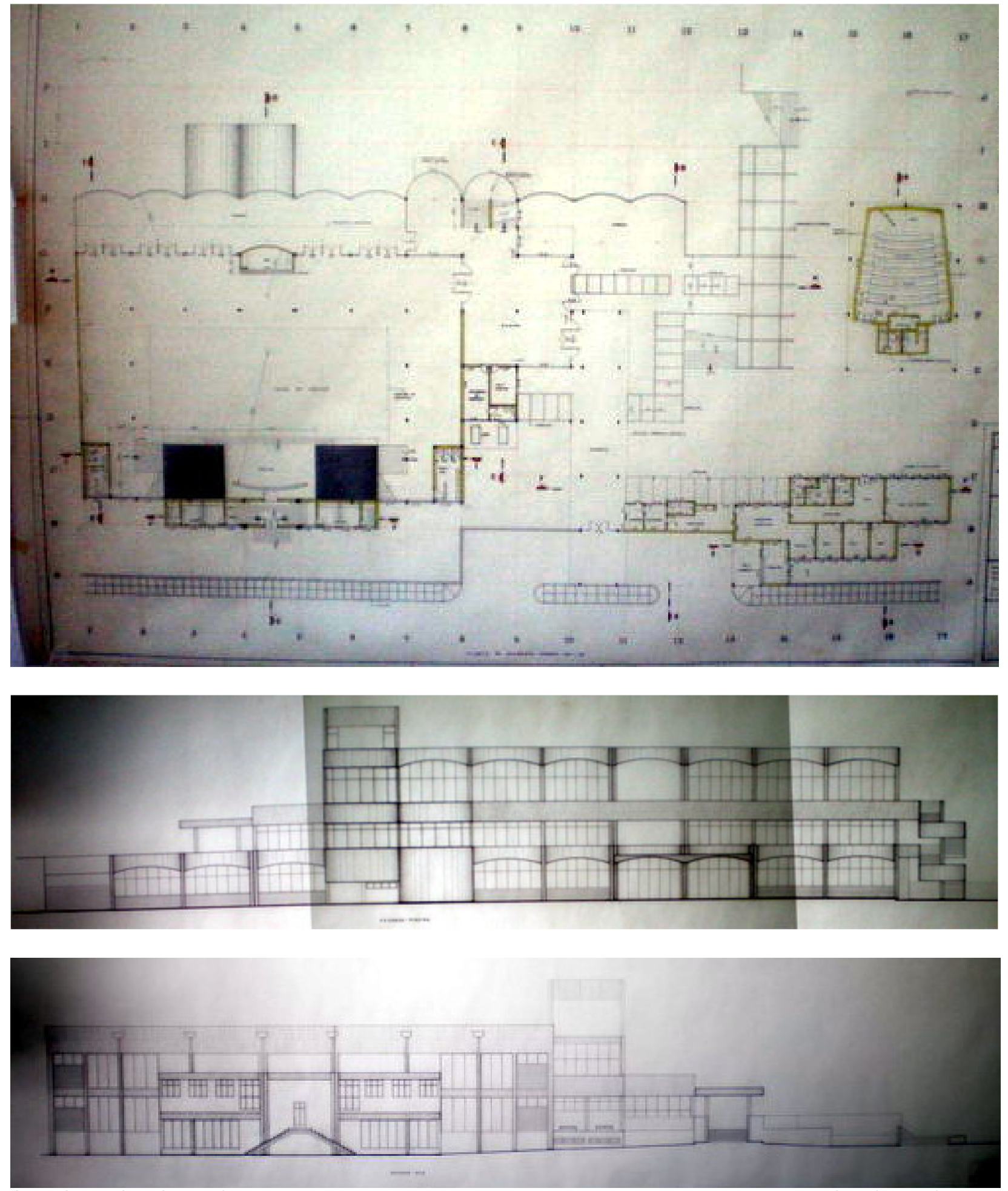

Sede Social São Carlos Clube. Implantação, elevação frontal e elevação posterior. Fonte: acervo São Carlos Clube 

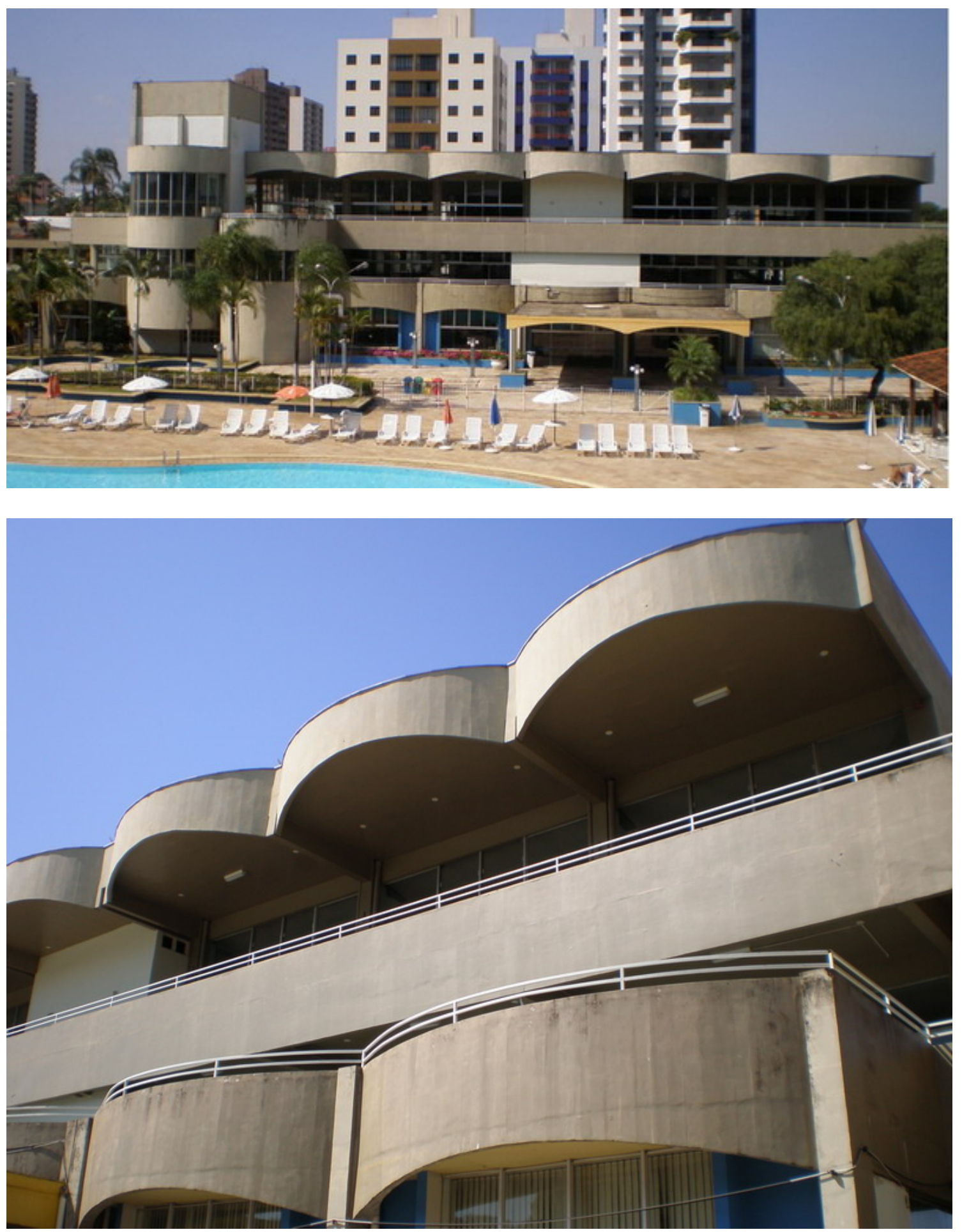

Fachada frontal e detalhe das sacadas. Fotos da autora. 


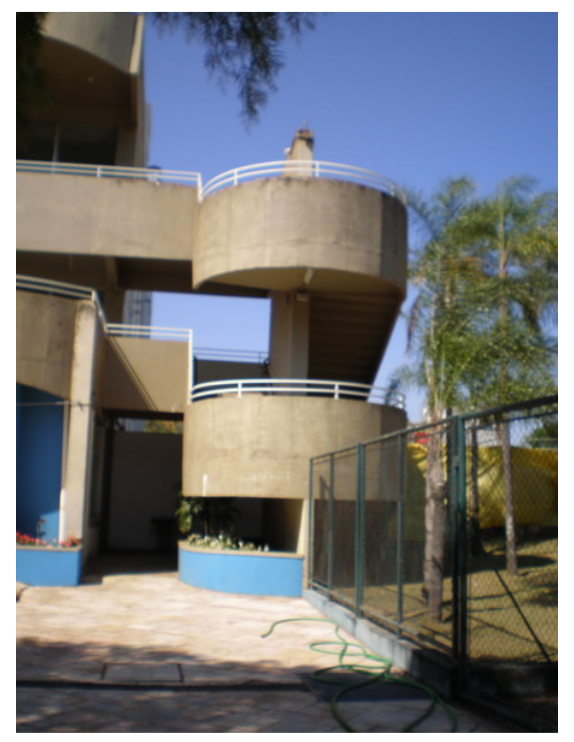

As sacadas poderiam se remeter às curvas da última fase wrightiana. Fujioka (2003) demonstra que desde os anos 30, Wright vinha investigando a questão da forma circular associando o círculo à idéia de plasticidade, unidade e continuidade, conceitos que perseguiu a vida toda e que permearam seus discursos.

O projeto do São Carlos Clube é marcado pelas aberturas generosas, pelo jogo dinâmico de recuos e projeções em balanço, pela fluidez do espaço interno e pela modulação quadriculada de $6 \times 6 \mathrm{~m}$ que regula aberturas e estrutura.

Uma linha horizontal marcante intercepta os dois pavimentos. Nove sacadas circulares dão ritmo à fachada e são interceptadas por outros volumes circulares que abrigam as caixas de escada.

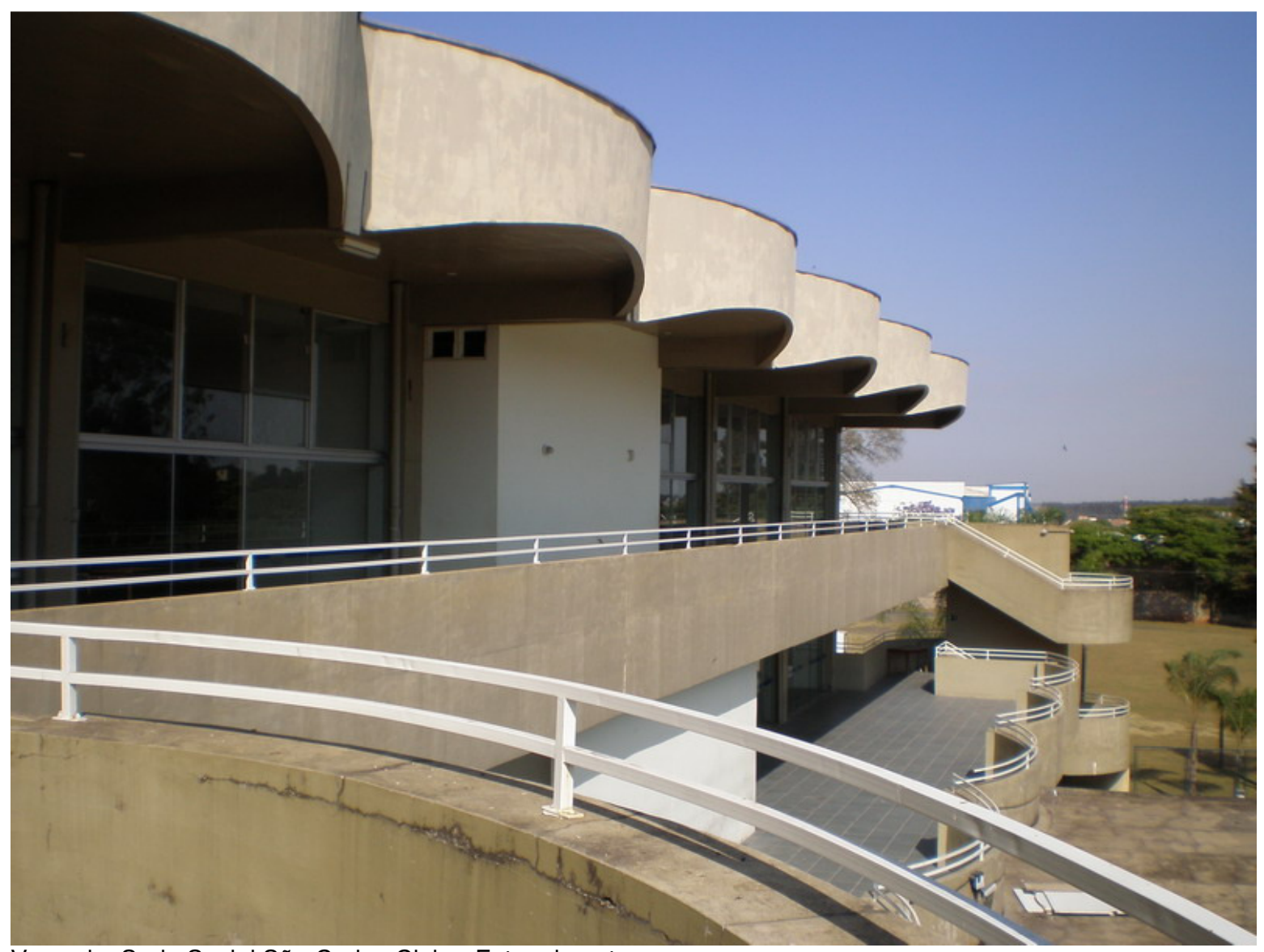



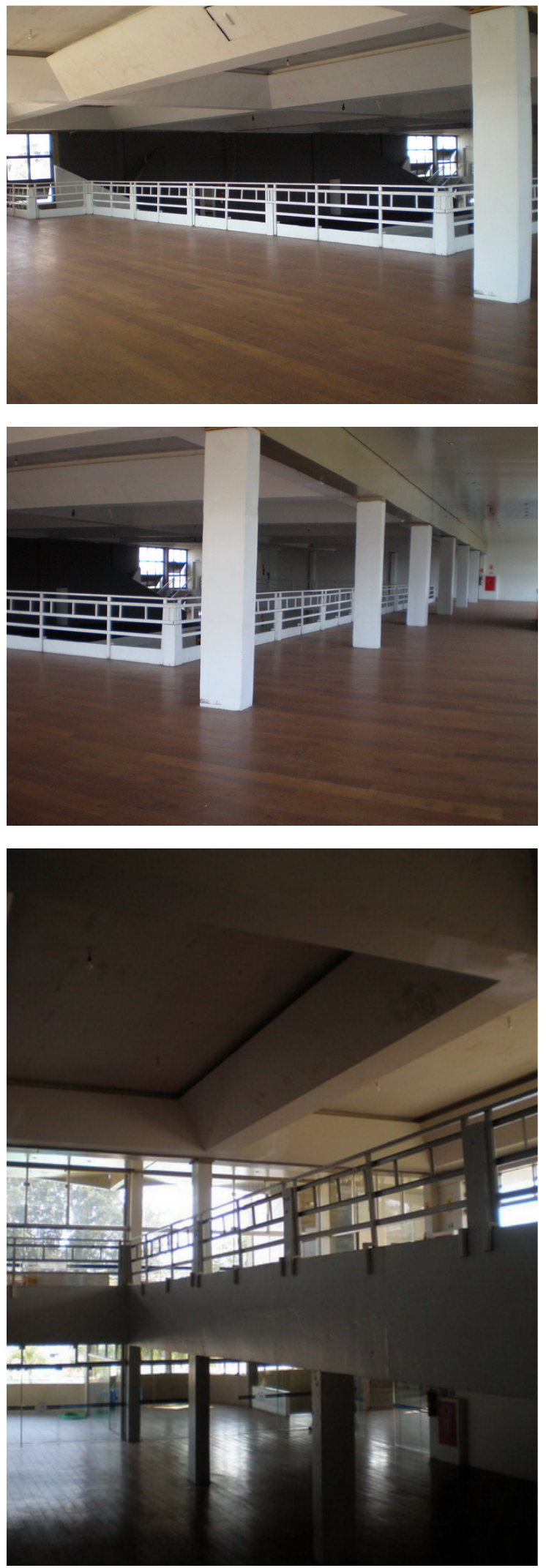

Vistas internas. Fotos da autora
Numa aproximação à Artigas, Gastão retoma em nova escala o conceito de arquitetura como abrigo. O grande salão de pé direito duplo é ladeado pelo mezanino envidraçado que se abre à varanda de frente para a piscina. Uma escada lateral descolada do corpo principal interliga as áreas avarandadas.

A cobertura se desenvolve com telhas de fibrocimento em sete águas rasas com calhas intermediárias que seguem a mesma modulação estrutural, conduzindo a água pluvial através dos pilares. Os pergolados surgem em alguns momentos, trazendo luz aos ambientes inferiores ou criando espaços transitórios entre interior e exterior.

Alguns projetos seguintes foram elaborados pela empresa Línea, com a participação de outros professores dentre eles, Celso Novaes e Roberto Luiz de Arruda Barbatto, que participaram inclusive dos cálculos estruturais do São Carlos Clube.

Após alguns trabalhos posteriores, a empresa se desfaz. Gastão estaria igualmente envolvido em compromissos com a docência que demandaram uma maior dedicação à Universidade. Um curto período de cerca de um ano seria dedicado à UNB, época em que se transfere para Brasília, deixando a família em São Carlos. Os anos que sucederam o período vivido na UNB estariam voltados ao ensino e à pesquisa de doutorado. Nesse período se implantava o mestrado na EESC e se estruturava o curso da ECA. 
III-ABRINDO CAMINHOS
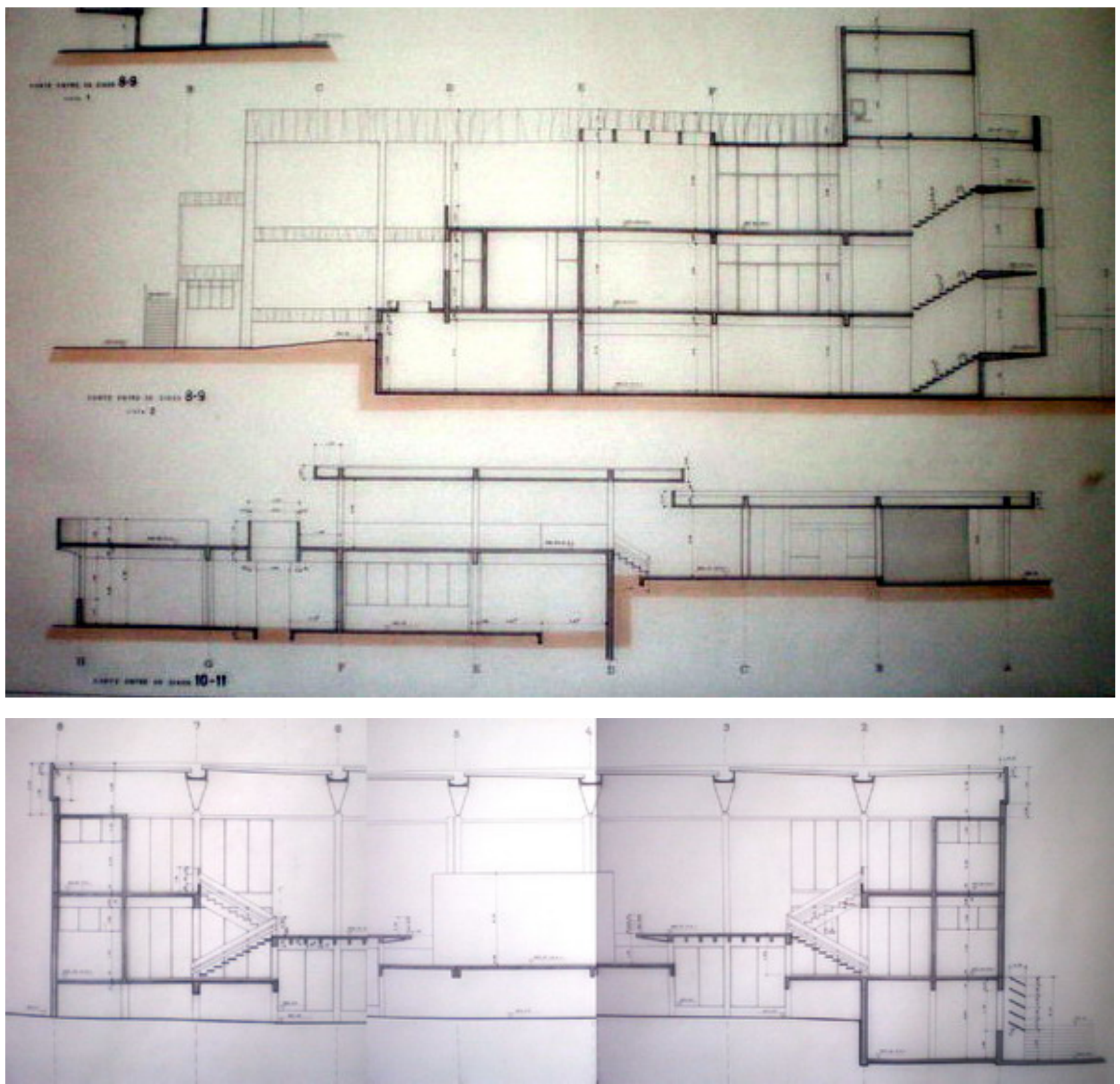

Sede Social São Carlos Clube. Cortes. Fonte: Acervo. São Carlos Clube

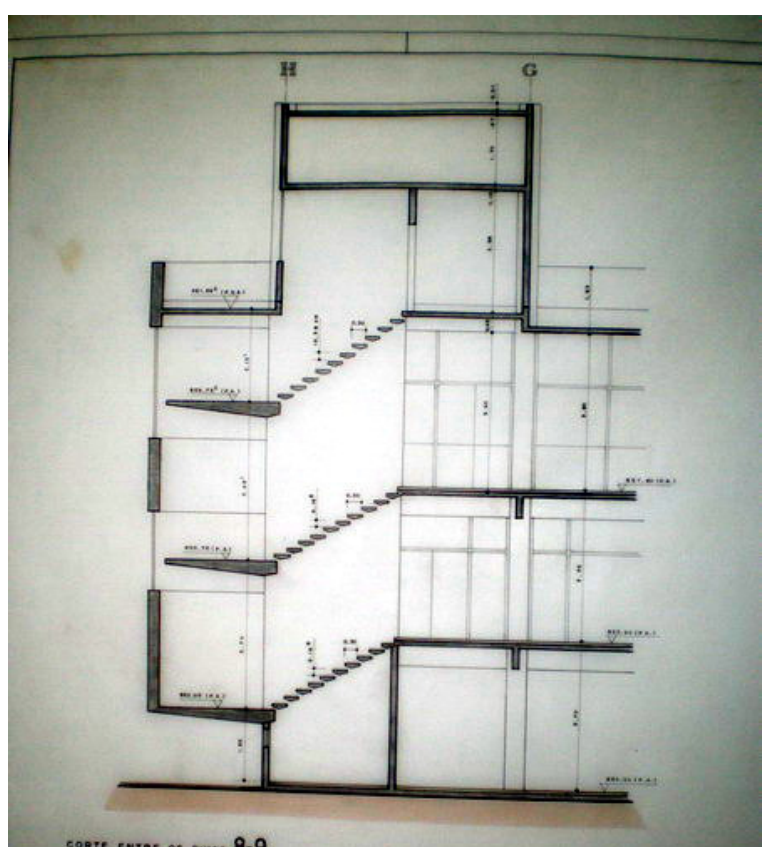




\section{Breves passagens: UNB e a ECA}

Em outubro de 1968, Luiz Gastão vai ao Distrito Federal como representante da FAU no Seminário de Re-estruturação do Instituto Central de Artes de Brasília, período em que a UNB passava por momentos delicados. Havia sido invadida em agosto, quando tropas do governo teriam agredido alunos, professores $\mathrm{e}$ parlamentares. Este ato precedeu o Al-5 e instaurou um clima ainda mais tenso no país.

Gastão havia sido eleito representante dos Instrutores da USP no Conselho Universitário para o triênio 1968-1970, no entanto em 1969, pede exoneração da Escola de Engenharia de São Carlos, prendendo-se ao fato de estar em vias de assinar contrato em regime de dedicação exclusiva com a UNB, como professor titular do Instituto Central de Artes da Universidade. Muito provavelmente, por razões políticas, Gastão ficaria em Brasília por pouquíssimo tempo. A situação dentro da Universidade na época da ditadura era algo que o entristecia profundamente e o clima na capital federal certamente era bem mais severo e tenso que no interior de São Paulo.

Voltando de Brasília, Gastão retoma suas funções na FAU e inicia um igualmente curto período como docente na recém criada Escola de Comunicações Culturais da USP, que acabava de incluir em seu currículo os cursos de Artes Plásticas e Música, passando a se chamar Escola de Comunicação e Artes (ECA).

Criada no contexto pós-golpe militar, num país com um plano político e econômico a ser viabilizado e um nacionalismo a ser silenciado, a escola 
nasceu com características muito mais ligadas à comunicação que às artes. $\mathrm{Na}$ época, tanto $\mathrm{o}$ Teatro como o Cinema não eram vistos como manifestações artísticas simplesmente, mas como meios de comunicação de massa.

Os primeiros professores foram contratados ainda em 66 através de um concurso público de títulos. Vindos das mais diversas áreas, trataram de desviar o curso do modelo inicial que obedecia à ideologia estabelecida pela ditadura militar.

(...) O projeto de criação da Escola de Comunicações Culturais da Universidade de São Paulo foi um projeto autoritário, dentro de um sistema autoritário (...)

Em 1968, o currículo original foi reformulado, incorporando as críticas e sugestões dos alunos, bem como as sugestões dos professores, no sentido de fugir aos padrões estrangeiros e adaptar mais o curso à realidade brasileira que incluía várias manifestações culturais como o Cinema Novo, os grupos do Arena e do Oficina,a Tropicália, o Pasquim, etc ${ }^{5}$

O ano de1969 inicia sob forte pressão do Al-5 nas universidades. No ano seguinte, o Conselho Federal de Educação (CFE) impõe o currículo mínimo para todas as escolas de Comunicação Social. A partir desse momento, a Escola perde autonomia curricular e passa a cumprir determinações do CFE. A Reforma Universitária vem em seguida, criando os departamentos.

Em março deste mesmo ano, Luiz Gastão é aprovado em concurso de títulos para exercer o cargo de professor colaborador na disciplina Artes

\footnotetext{
${ }^{5}$ Maria Helena Pires Martins. In A Escola de Comunicação e Artes e sua história. In Comunicações e Artes, São Paulo, (22) nov.1989. Pg 42
} 
Visuais junto ao Departamento de Cinema, Teatro, Rádio e Televisão (CTR) da ECA. Exerceria as funções de professor colaborador do departamento, cumulativamente ao cargo que mantinha na FAU.

$\mathrm{Na}$ ECA, teria sob sua responsabilidade promover atividades didáticas junto à disciplina Artes Visuais e Criatividade Visual. De acordo com o plano de trabalho que Gastão apresentou à Escola, todas as aulas deveriam ter caráter prático, havendo para cada conjunto de três semanas, uma aula de desenvolvimento teórico da matéria. Nesta ocasião, vinha desenvolvendo trabalhos de pesquisa e levantamento de dados para execução de sua tese de doutoramento e realizando pesquisas na área de Comunicação Visual, visando objetivamente os meios de comunicação coletiva (televisão, teatro e cinema). O objetivo central de sua pesquisa se embasava no desenvolvimento e aprimoramento das linguagens áudio-visuais dos meios de comunicação coletiva e o recebimento destas no plano da tecnologia do ensino. Gastão pretendia colaborar com os setores de televisão e cinema no tocante aos trabalhos de gravação de aulas e instruções, através das técnicas de vídeotape, tecnologia que vinha surgindo na época.

Embora este trabalho tenha sido considerado de grande relevância dentro do plano de ensino das diversas unidades da Universidade, não localizamos nenhuma gravação que mencionasse o trabalho de Luiz Gastão. Logo no início das atividades da Escola foram criadas várias instituições, dentre elas, o Museu da Imprensa. $O$ museu abrigou toda sorte de material gráfico e áudio visual produzido pela comunidade acadêmica. Durante a década de 70, muitos documentos da ECA e todo acervo do museu foram 
apreendidos e destruídos pela força repressiva da Ditadura.

Trata-se de mais um triste capítulo dos anos de chumbo. O Museu da Imprensa, idealizado pelo Prof. Marques de Melo, foi extinto e destruído em 1974, quando começava uma série de cassações de professores no Departamento de Jornalismo. Os responsáveis por esta execução achavam que o Museu abrigava material subversivo e decidiram exterminar tudo. O material nunca mais poderia ser recuperado. ${ }^{6}$

Gastão ficaria vinculado à Escola até maio de 1971, quando pede rescisão de contrato. A exemplo do fechamento do Museu, os anos seguintes seriam marcados por inúmeras medidas disciplinares, processos, sindicâncias, denúncias, reprovações em exames e cassações brancas. Em meio a greves e visitas militares, a ECA, assim como inúmeras outras Faculdades no país, andaram sob pressão até 75 sofrendo seus efeitos ainda nos últimos anos da década. ${ }^{7}$

\footnotetext{
${ }^{6}$ Bruder, Carsten. Forças e esforços: a criação do Departamento de jornalismo na ECA-USP

${ }^{7}$ Maria Helena Pires Martins. In A Escola de Comunicação e Artes e sua história. In Comunicações e Artes, São Paulo, (22) nov.1989. Pg 47
} 


\section{A organização de uma metodologia de trabalho e ensino}

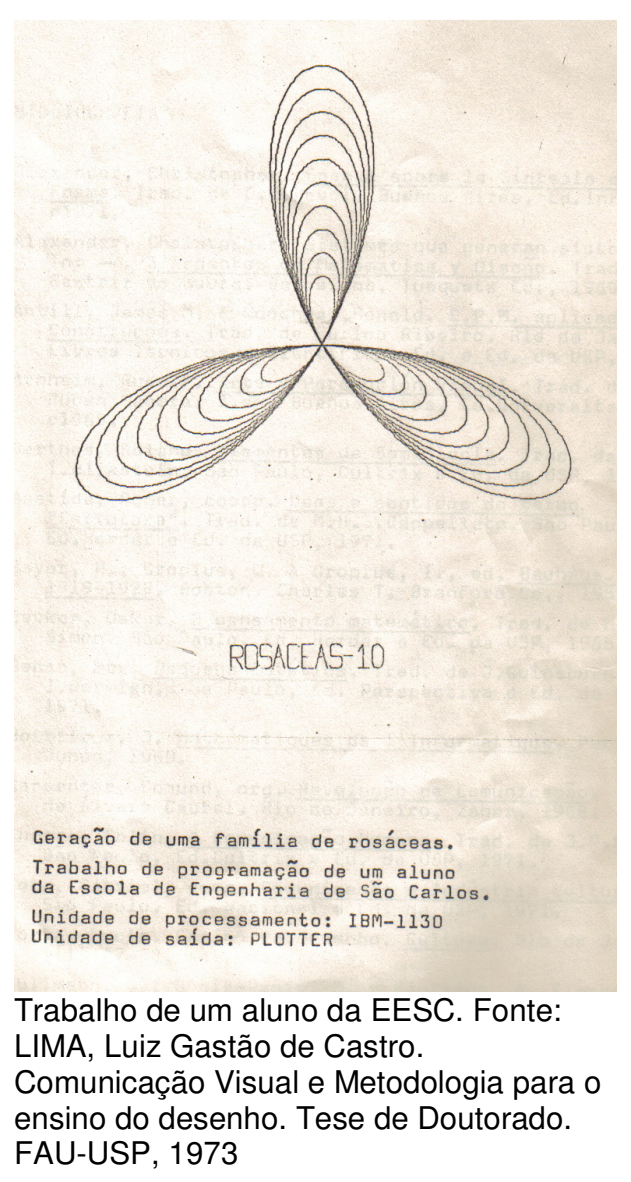

Raras vezes se deu conta de que os professores universitários estavam à míngua de conhecimentos capazes de estabelecer uma ponte que os ligasse à comunidade estudantil. (...)

Fizemos parte - de assistente a instrutor e depois de auxiliar de ensino da Faculdade de Arquitetura e Urbanismo- daquele elenco inteiramente despreparado para o ensino de arquitetura. Ensino cabalístico de uma escola de tradição, esclerosante quanto às origens, que de repente passou para um excesso de aberturas quanto aos objetivos.

Anos a fio oscilamos entre os atrativos da dedicação exclusiva e os encantos da atividade profissional.

chegamos, mesmo, a convencer-nos

de que o bom professor é o bom profissional liberal.

Era uma ilusão. ${ }^{8}$

Gastão continua, dizendo que sua experiência como educador mostrou-lhe que os únicos departamentos que foram capazes de estruturar bem seus cursos vincularam o corpo docente à dedicação exclusiva e à pesquisa voltada para a especialização com disciplinas pedagógicas. Isso não aconteceu na FAU, que tinha poucos professores exclusivamente ligados à Instituição. Estes, na sua grande maioria, dividiam-se entre as atividades didáticas e $\mathrm{o}$ trabalho de projeto em escritório de arquitetura. O empirismo marcou a estruturação das disciplinas oferecidas mesmo após a reforma do ensino em 1962. Segundo ele,

${ }^{8}$ Declaração de Luiz Gastão em LIMA, Luiz Gastão de Castro. Comunicação Visual e Metodologia para o ensino do desenho. Tese de doutorado. FAU-USP. São Paulo, 1973. 
houve um estudo intenso, individual e coletivo, que se aventurou na experimentação e foi marcado pela ausência de métodos de trabalho voltados para o ensino.

Buscávamos a biblioteca da Escola- verdadeiro paraíso onde engolíamos as obras e as palavras de algumas figuras exponenciais, tentando depois impingi-las aos alunos, através de fraca metodologia.

Claro está que com tal atitude, obtivemos evidente progresso: as idéias colhidas lá e cá transformaram-se em sedimento válido.

$\mathrm{O}$ que nos faltou foi uma digestão que tirasse a antropofagia necessária do estágio de indigestão bibliográfica.

Muitas vezes nossa formação foi "aprimorada" pela experiência das propostas dos escritórios e alimentada com a leitura apressada de revistas profissionais que mostravam o denier cri da moda arquitetônica internacional. ${ }^{9}$

$\mathrm{Na}$ altura em que a qualificação docente no nível de pós-graduação se torna condição de permanência nos quadros da universidade, a FAU inicia os cursos pós-graduados em Arquitetura.

Não fora nossa persistência no tentar vencer um desafio e teríamos deixado a docência nesse período. (...)

Não conhecíamos métodos de trabalho e não poderíamos conhecer métodos de aprendizagem. Felizmente, tivemos sempre plena consciência de todos esses problemas e procurávamos um caminho que nos orientasse na função universitária, decidido a deixá-la se nada

${ }^{9}$ Idem, ibdem 
encontrássemos - o que ocorreu com muitos dentre nós, que se afastaram. ${ }^{10}$

De início, os cursos de pós-graduação foram encarados como mera formalidade, legalmente necessária, mas com o tempo transcenderam a preocupação burocrática e foram o ponto inicial para o aperfeiçoamento do corpo docente e para o preenchimento da lacuna existente entre 0 aprendizado e o ensino. Gastão continua:

Elementos da casa e de fora foram recrutados e trouxeram a esta Faculdade uma contribuição que foi, em nossa opinião, a maior de toda sua história. A repercussão dos cursos de pós-graduação ali realizados foi também uma das mais importantes no currículo didático das Faculdades de Arquitetura nacionais.

Levado à qualificação, Luiz Gastão passa diretamente ao doutorado sem se submeter ao grau de mestre, e tem nesse momento a oportunidade de revisar os métodos didáticos aplicados até então no ensino do desenho.

Duas disciplinas cursadas na FAU em 66 teriam contribuído nessa revisão: "Introdução à teoria da Comunicação" com Ernst Robert de Carvalho Mange e "Metadesign", sob a responsabilidade de José Maria da Silva Neves com a participação do designer holandês Andries Van Onck. Teria nesse momento sido levado a um campo absolutamente novo, não apenas através da disciplina de Van Onck, mas da fusão destas com a leitura dos trabalhos de Teodoro Oniga.

\footnotetext{
${ }^{10}$ Idem, ibdem
} 
E foi também nesses cursos que germinou

a idéia aqui colocada, hoje,

sob a forma de tese e que,

intransigentemente, procuraremos defender:

A organização de uma metodologia de trabalho e de ensino. ${ }^{11}$

Sob o título "Comunicação Visual e Metodologia para o Ensino do Desenho", a tese apresentada por Luiz Gastão à Faculdade de Arquitetura e Urbanismo da USP para obtenção do grau de Doutor, apresenta base bibliográfica sedimentada basicamente na Teoria da Informação e se desenvolve apoiada nas teorias do design surgidas a partir do pioneirismo da Bauhaus e da Hochschule für Gestaltung de UIm.

O apoio bibliográfico a este trabalho, é pois, copioso, embora "informativo" demais (com fortes tendências, portanto, à entropia)

As idéias foram, por isso, desenvolvidas com a necessária cautela: a tese há que ser entendida como mais uma contribuição de um arquiteto ao complexo campo do ensino, contribuição esta que, por vício de origem, não poderia deixar de ser um pouco estrutural, mercê do relacionamento entre o autor e o "struere". ${ }^{12}$

Na tese Gastão se aprofunda no conceito de sistema com base na definição de Norbet Weiner, entendendo-o como um conjunto de partes interligadas, organizado para realizar um

${ }^{11}$ Idem, ibdem

12 Luiz Gastão de Castro Lima in LIMA, Luiz Gastão de Castro. Comunicação Visual e Metodologia para o ensino do desenho. Tese de doutorado. FAU-USP. São Paulo, 1973.

Associado à Teoria da Informação, o termo entropia aparece nesta frase de Gastão, cheio de significados. 
determinado processo, visando um objetivo definido.

Tomando a Escola como um sistema complexo, mas flexível a novas metodologias, Gastão constrói uma abordagem que direciona o ensino para sua finalidade dentro do sistema maior: as Escolas de Engenharia. A tese é uma síntese do trabalho que o arquiteto vinha realizando até então, junto às experiências acumuladas em vinte anos de vida docente. ${ }^{13}$ Dizia ele: "esse trabalho foi elaborado sobre nossa experiência didática, a partir da maturação forçada a que nos submetemos. "

Gastão questionava o método usual de ensino de desenho nas escolas técnicas, que caminhavam para exercícios de representação de objetos. Não descartava a representação em si, mas buscava demonstrar que esta deveria ser entendida dentro do processo criativo não como um fim, mas como meio. Entendia ter o curso, uma função formativa e defendia intransigentemente que se estruturassem fundamentos gerais e consistentes. Dizia ele:

\footnotetext{
Entendemos que 0 curso de engenharia tem aspectos de meta-lingagem científico-tecnológica, devendo dar formação suficiente ao profissional para habilitá-lo a enfrentar qualquer problema que surja na sua área de opção.
}

O doutorado se desenvolvia em paralelo à aplicação dessa nova metodologia nos cursos de Engenharia e esta servia de base empírica para as teorias defendidas na pesquisa. Gastão trabalhava

\footnotetext{
${ }^{13}$ A tese é defendida em setembro de 1973. Fizeram parte da banca julgadora, o Prof. Doutor José Maria da Silva Neves, Lafael Petroni, Paulus Pompéia, Lúcio Grinover e Hélio Duarte (orientador). Tendo os dois primeiros Ihe concedido as maiores notas. A tese foi publicada em edição restrita na FAUUSP.
} 
com os alunos com exercícios ligados ao desenho arquitetônico e a esquemas topográficos, estes últimos a fim de aferir capacidade de visualização espacial ligada aos cursos de Engenharia Civil, Engenharia Mecânica e Engenharia Elétrica.

A valorização crescente das disciplinas de desenho na escola de Engenharia de São Carlos indica que houve aceitação, pelo menos parcial, das idéias ventiladas a partir de 1968, e que foi desencadeado um processo de reformulação do ensino desta disciplina. Esta idéia está em ebulição e cremos possível ir implantando progressivamente os princípios aqui expostos. ${ }^{14}$

\section{A criação do SAP e o Mestrado em Industrialização da Construção}

Aqui no Brasil, partiu da Faculdade de Arquitetura e Urbanismo da USP em 1962 a primeira reformulação do ensino de Arquitetura, com a introdução do desenho industrial e comunicação visual como matérias curriculares, valendo-se da experiência dos grupos de Ulm.

Esta reformulação vem de ser extremamente aprimorada com a instalação do Curso de pósgraduação de Industrialização das Construções em 1971, na Escola de Engenharia de São Carlos, da USP. Como esta escola possui a infra-estrutura necessária, as condições que tem, de bem desenvolver o ferramental teórico-prático adequado, são as mais favoráveis. ${ }^{15}$

${ }^{14}$ Luiz Gastão de Castro Lima em LIMA, Luiz Gastão de Castro. Comunicação Visual e Metodologia para o ensino do desenho. Tese de doutorado. FAU-USP. São Paulo, 1973

${ }^{15}$ Luiz Gastão de Castro Lima em "Plano de Trabalho do Arquiteto Luiz Gastão de Castro Lima, que exercerá as funções de professor colaborador na Escola de Engenharia da Universidade de São Paulo, em regime de turno completo." Documento integrante do Processo de Contratação do arquiteto como Professor da Escola de Engenharia de São Carlos. 
O último ano da década de 60 foi marcante na história da USP. Em 1969 é aprovado o Estatuto da Universidade, em parte como conseqüência dos debates realizados no Fórum Universitário que teve lugar um ano antes. A partir do novo Estatuto é criado o SAP - Departamento de Arquitetura e Planejamento da Escola de Engenharia de São Carlos. A princípio, partindo da idéia de criar um campus de Arte, Ciências e Tecnologia, materializou-se como um desdobramento do departamento de Estruturas e Arquitetura, já existente. Num primeiro instante, oferecia apenas Mestrado e caminhava numa linha que muito interessava a Luiz Gastão.

"Até 73 eu mantinha um cordão umbilical ainda fortemente ligado à FAU. Em 72 eu transferi meu cargo para a Escola de Engenharia, departamento de arquitetura, porque em 71 se iniciava um curso de pós-graduação na área de arquitetura, com uma ótica voltada para uma problemática que me interessava muito, que era a dos problemas da construção e da tecnologia na arquitetura." ${ }^{16}$

$\mathrm{Na}$ época, grande parte dos cursos de arquitetura eram voltados ao planejamento, a exemplo da Universidade de Brasília, de Pernambuco, da Federal do Rio Grande do Sul e também o curso da FAU, que só se inclinaria a outras áreas futuramente.

Paulo de Camargo e Almeida, criador do Departamento, justifica o nome ao fato de se enquadrar o planejamento em um patamar mais abrangente que o urbanismo. Essa estruturação com base no planejamento era justificável. A escassez de profissionais pós-graduados na área 
de arquitetura levou muitos cursos a se estruturarem de forma interdisciplinar, onde seria possível compor um corpo docente com doutores em áreas diversas da arquitetura, como a sociologia, geografia, história e economia.

Apesar do nome, o Departamento de Arquitetura e Planejamento da Escola de Engenharia de São Carlos, previa o direcionamento das pesquisas no ramo da Industrialização das Construções do Planejamento, concebidos como temas indissociáveis desde o Seminário de Habitação e Reforma Urbana ocorrido em 1963. ${ }^{17}$

Gastão se lembra das dificuldades em estruturar os trabalhos iniciais, o que acabou por criar a necessidade de uma articulação entre o SAP e os departamentos de Engenharia Civil e Mecânica.

"Para que um curso de pós-graduação funcione é necessário que exista um número mínimo de docentes graduados, de doutor para cima, doutor adjunto, livre docente, titular. Não existe doutor no Brasil em arquitetura. Os únicos que existem são os da FAU, trinta e poucos.

O nosso curso é só voltado para a tecnologia, então tem lutado com muitas dificuldades, principalmente pelo fato de existirem poucos profissionais titulados em arquitetura ou engenharia." 18

Com o corpo docente articulado e valendo-se de seus contatos no meio acadêmico, Gastão convida professores de outras instituições a participar do programa de pós-graduação da EESC,

\footnotetext{
${ }^{16}$ Declaração de Luiz Gastão de Castro Lima in Instituto de Arquitetos do Brasil (1979) ${ }^{17}$ KOURY, Ana Paula. Arquitetura Construtiva. Tese de Doutorado. FAU-USP. São Paulo, 2005.

${ }^{18}$ Declaração de Luiz Gastão de Castro Lima in Instituto de Arquitetos do Brasil (1979)
} 


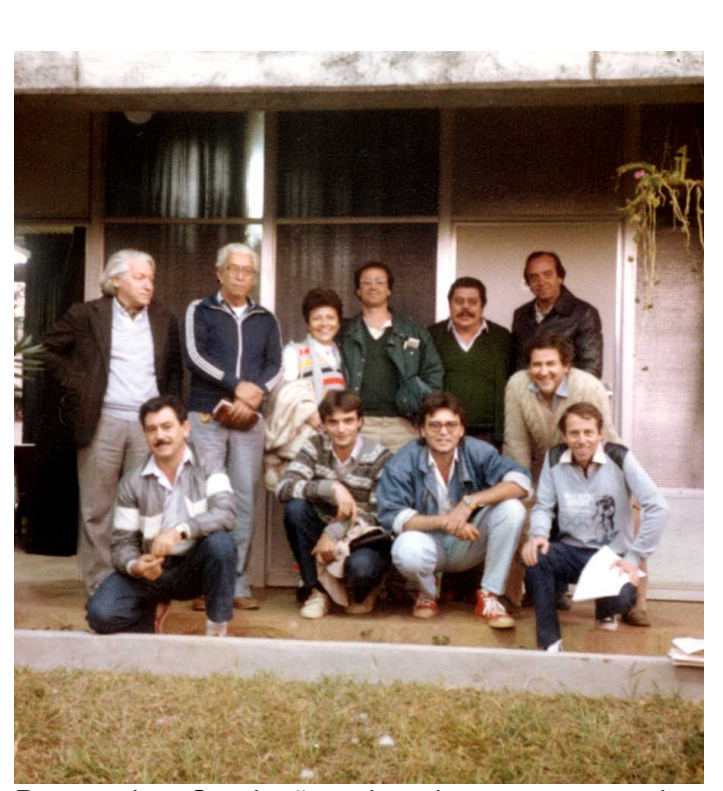

Parte da Comissão do departamento de Arquitetura e Planejamento da EESC. Em pé da esquerda para a direita: Cláudio Gomes (convidado externo); Luiz Gastão de Castro Lima (Chefe do SAP), Roti N. Turin (convidada externa); Agnaldo Farias; Itamar M. Amador; Spencer P. Nogueira (professor do SAP, mas, não membro da comissão). Sentados: Ruy L. Balseiro (secretário do SAP); Carlos A. F. Martins; Gelson de A. Pinto; Azael Rangel Camargo e Laercio F. e Silva.

A data provável da foto é 1972 ou 73.

Fonte: Camargo, Azael Rangel. Notas sobre a história do Departamento de Arquitetura e Urbanismo da Escola de Engenharia de São Carlos da Universidade de São Paulo. Texto fornecido pelo Prof. Eduvaldo Sichieri a fim de promover o crescimento e a consolidação do departamento.

A orientação do Planejamento no Programa de Pós-graduação da EESC seria abalada com a ida de Paulo de Camargo e Almeida para Paris por pressões políticas. Celso Lamparelli e Azael Rangel Camargo dariam seqüência aos trabalhos por mais alguns anos, mas a morte de Camargo e Almeida em 73 deixaria na EESC uma lacuna intelectual à espera de um novo líder. ${ }^{19}$

O Departamento de Arquitetura e Planejamento da EESC (SAP) se consolida até 1984 e retém a responsabilidade das disciplinas de Desenho na formação de profissionais dos cursos de Engenharia Mecânica e Elétrica, tarefa essa que ficou a cargo de Luiz Gastão.

As discussões acerca da montagem de um curso de graduação em Arquitetura na Escola de Engenharia de São Carlos começam a ganhar corpo nos anos seguintes. Gastão assume o cargo de Coordenador do Curso e Presidente da Comissão de Assessoramento Didático, que tinha a função de orientar e estruturar o currículo do curso de arquitetura pretendido pela EESC.

Gastão apoiou a implantação do curso até o fim. Defendeu-o com convicção perante a Congregação e a certa altura, deixou que tomassem a frente dos trabalhos, os jovens docentes: "esse curso é de vocês, dizia ele". ${ }^{20}$

Implantado em 1985, o curso de graduação da EESC foi centrado numa proposta que pretendia formar um profissional "apto à reflexão histórica e teórica, mas com domínio dos meios

${ }^{19}$ Sobre a criação do Departamento de Arquitetura e Planejamento da EESC, ver ALTAFIM (2003)

${ }^{20}$ Carlos Martins em depoimento à autora. 
contemporâneos", com ênfase nos aspectos projetual, tecnológico e teórico.

\section{O retorno definitivo a São Carlos}

Após as passagens por Brasília e pela Escola de Comunicação e Artes, Gastão recebe um convite insistente de Paulo de Camargo e Almeida para que se transfira definitivamente para São Carlos, assumindo as funções na EESC em regime de exclusividade. Nunca the ofereceu atrativo estabelecer vínculos exclusivos com a instituição. Gastão sempre buscou manter-se atuante profissionalmente realizando em paralelo à vida docente, projetos de arquitetura em seu próprio escritório.

Elabora na ocasião, um Plano de Trabalho para exercer as funções de professor colaborador em regime parcial, substituindo Battaglia que havia pedido demissão do departamento.

Dada indicação e insistência de Luiz Gastão, Carlos Welker e Domingos Bataglia, ambos seus ex-alunos na FAU, haviam sido contratados pela Escola de Engenharia de São Carlos em 1969. A chegada dos novos docentes havia permitido a divisão das turmas e um melhor assessoramento aos métodos propostos por Gastão para o ensino do desenho nos diversos desdobramentos da engenharia. Bataglia atuava na área de tecnologia e Welker na área de planejamento. Ao se desligar da Escola ao final de 1968, voltando sua atenção à Brasília, Gastão havia deixado a cargo de seus substitutos, a continuação das diretrizes iniciais e a ampliação do número das disciplinas dedicadas ao desenho. 
Em abril de 71, Nestor Goulart concorda com a transferência definitiva de Luiz Gastão para a EESC. $\mathrm{Na}$ ocasião, havia poucos profissionais dotados para a área de Comunicação Visual, o que tornava sua vinda muito importante e desejada pelo departamento.

Os vínculos com a FAU representaram inúmeros obstáculos à sua contratação. Nesta ocasião, Lafael Petroni, então chefe em exercício do SAP, encaminha uma carta a Morency Arouca, diretor da Escola, reiterando os pedidos anteriores. Justificava a insistência da solicitação a dificuldades em se encontrar professor titulado nessa área. Enfim, em 1973 se consolida a contratação, ano em que Gastão conclui o doutorado.

Ao retornar à Escola de Engenharia, Gastão assume a disciplina Desenho Técnico Civil e a coordenação de todo o grupo de disciplinas ligadas ao ensino do desenho (Geometria Descritiva, Perspectiva, Geometria cotada e axonometria, Desenho técnico civil, Desenho técnico mecânico e elétrico e uma optativa de Desenho arquitetônico) e introduz a disciplina Desenho Industrial, ainda como optativa.

A introdução de uma nova modalidade do desenho abre ao arquiteto a oportunidade de rever uma série de estudos realizados anteriormente no que diz respeito aos meios de produção industrial.

Logo nos primeiros anos do departamento, a pós-graduação em Industrialização da Construção já atraia grande número de alunos não apenas de São Carlos, mas de Ribeirão Preto, Bauru, Piracicaba, São José do Rio Preto e também da capital do estado. Muitos ficaram sob a orientação do arquiteto que acumulava grande carga didática. 
Nesse momento, assumia a coordenação de área da FAPESP, exercia atividades ligadas aos objetivos básicos da pesquisa proposta em sua tese e lecionava a disciplina Arquitetura e Comunicação Visual, parte integrante do grupo de disciplinas do SAP. Esta disciplina tinha como objetivo básico o complemento à formação cultural do pós-graduando, com a introdução de noções mais profundas emanadas das áreas de Comunicação, principalmente nos aspectos exploratórios da Teoria da Informação, da Semiologia e da Análise da Sociedade de massa.

Estes foram os principais aspectos norteadores de sua tese e mostram a preocupação inicial do departamento que mantém a mesma linha de pensamento até os dias de hoje, buscando formar profissionais com visão abrangente, elaborando um processo de trabalho que busca mais a formação global que a informação pontual.

Para Gastão, as noções de Semiologia e da análise da sociedade de massa, bem como das teorias da informação eram da maior importância para a abordagem dos problemas decorrentes da Industrialização das Construções.

$\mathrm{Na}$ época, manifestava a intenção de publicar, ainda que de forma resumida, os trabalhos desenvolvidos na disciplina. Esta aceitou alunos das mais variadas áreas ligadas à Comunicação e Arquitetura, sendo considerada isolada para os estudantes não inscritos no programa de mestrado da EESC. Este fato acabou por permitir o ingresso de alunos oriundos de áreas distintas e enriqueceu seminários e trabalhos programados, levando ao cumprimento de um programa comunitário e colaborando com áreas carentes de outros cursos de pós-graduação. 
Era uma disciplina muito concorrida e muito interessante, que tinha uma composição eclética. Havia alunos de várias áreas. Na minha turma, duas eram bibliotecárias, havia também dois advogados e os que eram da arquitetura e engenharia. Dessa forma, conseguíamos trocar uma quantidade de informação muito grande com universos diferentes. Eram mundos diferentes onde cada um colocava sua vivência, da sua escola. $^{21}$

Gastão também havia ministrado a convite da FAU-USP, a disciplina "Introdução ao Processamento de Dados com aplicações ao Planejamento Territorial", dentro do curso de Mestrado em "Estruturas Ambientais Urbanas". Esta disciplina teve o objetivo de introduzir toda metodologia estrutural de modelos quantitativos no Planejamento, a partir da idéia básica da pesquisa operacional e processamento de dados, abordando modelos de programação linear, modelos ligados à Teoria dos Grafos e Introdução ao PERT. ${ }^{22}$ arquiteto demonstra em sua tese de doutoramento que muitas destas teorias já haviam sido aplicadas por ele na EESC com excelentes resultados. ${ }^{23}$

${ }^{21}$ José Alfeu Rohm em entrevista concedida à autora em 22 de fevereiro de 2008. Rohm, amigo e colega de trabalho de Gastão, foi um dos alunos que cursou a disciplina sem estar inscrito no processo de mestrado.

${ }^{22}$ As técnicas denominadas PERT (Program Evaluation and Review Technique) e CPM (Critical Path Method) foram desenvolvidas de forma independente para auxiliar no planejamento e gerenciamento de projetos, no início dos anos 1950. Pensadas no sentido de auxiliar na execução não apenas de projetos, mas também em pesquisas e desenvolvimento de produtos, produção de filmes, instalação de sistemas de informação, utilizando principalmente os conceitos de redes (grafos) para planejar e visualizar a coordenação das atividades do projeto. Gastão se interessou intensamente pelo tema, quando ainda estava em fase de implantação no Brasil. Parte do resultado destes estudos está relatada em sua tese de doutoramento e no artigo A elaboração dos organogramas funcionais a partir da Álgebra de Boole e da Teoria dos Grafos, trabalho em andamento desde o início da década de 50, e que Gastão teria intenção em publicar. Este artigo faz parte do processo $6581 / 56$ da USP.

${ }^{23}$ LIMA, Luiz Gastão de Castro. Comunicação Visual e Metodologia para o ensino do desenho. Tese de Doutorado. FAU-USP, 1973 
Nesta altura, o arquiteto desenvolvia dois trabalhos para posterior publicação, um deles abordava a elaboração dos organogramas funcionais a partir da álgebra de Booles e da Teoria dos Grafos e o outro discorria sobre Holografia e Comunicação Visual. Orientava na Escola de Engenharia de São Carlos dez alunos de Mestrado, dentre eles, quatro vinham de Pernambuco, Itamar Amador da UNB e Admir Basso do Mackenzie.

Esta extensa jornada acadêmica demandava exaustivo trabalho de pesquisa e levantamento bibliográfico. Além disso, Gastão assumia grande carga didática na área de Desenho do Departamento de Arquitetura e Planejamento, sendo responsável por todos os cursos básicos de desenho, o que reunia cerca de mil alunos com sete disciplinas sob sua coordenação, sendo que quatro destas estavam sob sua responsabilidade direta. Além disso, procurava aumentar a atuação do departamento no programa de Prestação de Serviços à Comunidade, tendo executado o anteprojeto da Casa Do Professor (Unidade Regional do Centro do Professorado Paulista). A idéia seria desenvolver 0 ante-projeto através do Departamento, mediante convênios. ${ }^{24}$

Lafael Petroni, com quem Gastão dividia a chefia do departamento, atribui a este fato as razões que levaram sua produção de publicações não ter se consubstanciado completamente. Petroni atesta, em carta ao Presidente da CRTC, seu acompanhamento às pesquisas de Gastão, verificando 0 desdobramento do arquiteto ao ministrar disciplina tão concorrida como era Arquitetura e Comunicação Visual e ao mesmo tempo desenvolver intensa atividade de orientação.

\footnotetext{
${ }^{24}$ Não localizamos o ante-projeto supra citado.
} 
Durante muitos anos, ao longo da década de 70, dentro da Escola de Engenharia de São Carlos, Gastão foi o único docente com titulação de Doutor na área, o que fazia com que a procura de candidatos por sua orientação superasse a capacidade de seu tempo disponível. Essa grande procura acabou por levá-lo a orientar temas dos mais diversos, não se detendo exclusivamente a áreas de seu interesse.

"O Gastão dava grande margem de pesquisa para todos, não fechava em função de ser mais conhecimento pra ele, e isso deu margem a uma orientação direta. Talvez fosse isso que precisávamos naquele momento na pós, quando os grupos de pesquisa ainda não existiam. Dessa forma, ele deu oportunidade de cada um crescer naquilo que mais Ihe dava prazer." 25

Em pouco tempo, a EESC começou a receber um grande fluxo de estudantes vindos do norte e nordeste à procura de qualificação em São Paulo. Tal fato se pautava na expansão de Faculdades Federias nas capitais dos estados.

Segundo os depoimentos, Gastão exercia uma grande atração nos alunos. Estes o cercavam e a aula se estendia para além dos domínios da Escola.

As aulas da pós eram à noite. Tinha muitos alunos de fora que davam aulas na região e havia professores que estavam começando a carreira na Federal. Eles saiam depois da aula para o bar Barbosa, na [Rua] Conde, que era muito mais modesto do que é hoje. Era um local agradável, íamos lá, juntávamos as mesas e a aula

\footnotetext{
${ }^{25}$ Maria Ângela Bortolucci em depoimento à autora.
} 


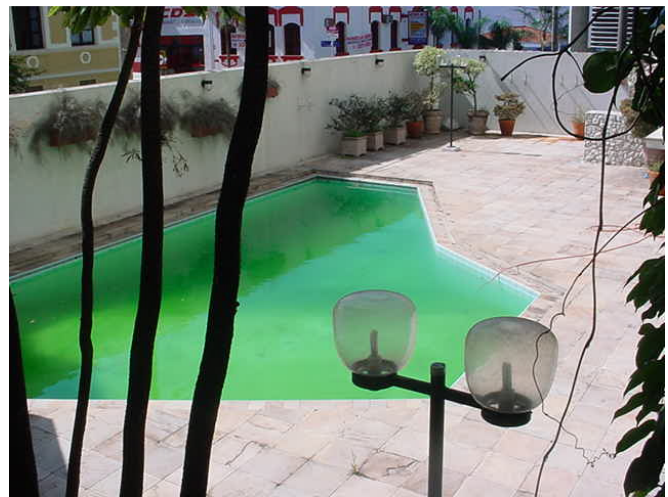

Piscina. Hotel Azouri antes da reforma iniciada em 2007. Fonte: Fotos da autora continuava. O Gastão tinha muito conhecimento, uma bagagem muito variada, de um assunto puxava outro e todos se encantavam com a conversa dele. ${ }^{26}$

Apesar da extensa atividade acadêmica, Gastão nunca abriu mão de algo que the dava muito prazer: a culinária. Segundo os amigos, seu conhecimento sobre o tema era tão profundo e variado, quanto seu conhecimento profissional. Conciliou tudo isso abrindo seu próprio bar na década de 80 , em parceria com o professor Mário Arturo Guide. Segundo relatos, era o bar da boemia onde o arquiteto se cercava de amigos, mas a experiência não durou muito tempo.

\section{COE}

Em São Carlos, durante a década de 70, em meio a diversos projetos residenciais, Gastão realiza uma série de intervenções no Hotel Azouri, época em que este passa a ser administrado pelo grupo Vila Rica. Dentre estas intervenções, visando incluir no programa requisitos exigidos em hotéis de alto padrão, está o estudo para a piscina e o muro(demolidos em 2007). O espaço deu lugar à entrada principal na reformulação do edifício feita pelo escritório paulistano Piratininga. $\mathrm{O}$ hotel passou a ser a partir de então, o Paço Municipal. ${ }^{27}$

Neste mesmo ano, Gastão é convidado a colaborar na implantação do COE - Centro Odontológico Especializado de São Carlos. O COE São Carlos foi idealizado pelo Dr Fábio de Angelis

\footnotetext{
${ }^{26}$ Maria Ângela Bortolucci em depoimento à autora.

${ }^{27}$ O Hotel Azouri, marco referencial na cidade de São Carlos, foi fruto de um concurso de anteprojetos realizado em 1953, vencido por Fábio Penteado e Lucjan Korngold
} 
Porto, como parte das pesquisas realizadas em sua tese de Livre Docência, defendida em 1975.

Convidado a realizar um projeto com base em planta pré-definida, Gastão inicia uma série de estudos para a implantação de uma clínica odontológica que previa um sistema operacional organizado de forma racional. $\mathrm{Na}$ época não existiam normas técnicas que tratassem do tema e o trabalho pioneiro de Angelis Porto serviu de referência para muitas cooperativas médicas e odontológicas que a sucederam.

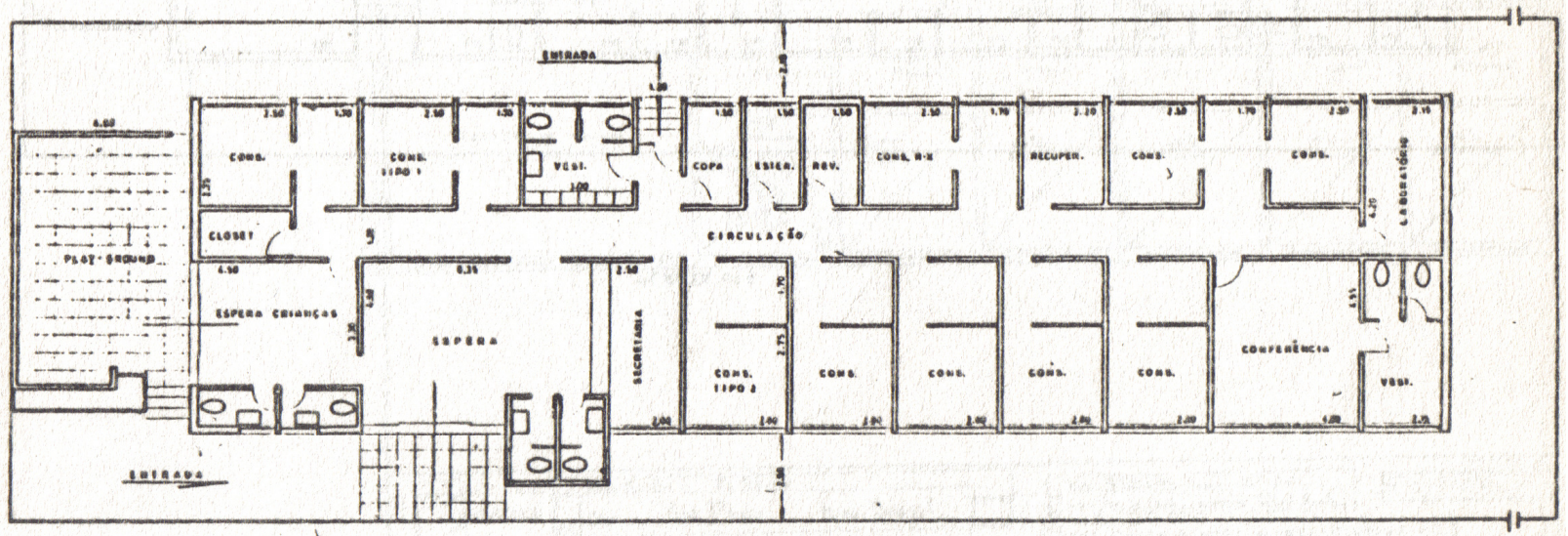

Planta geral 1:100 area $330 \mathrm{~m}^{2}$

PLANTA n? 9

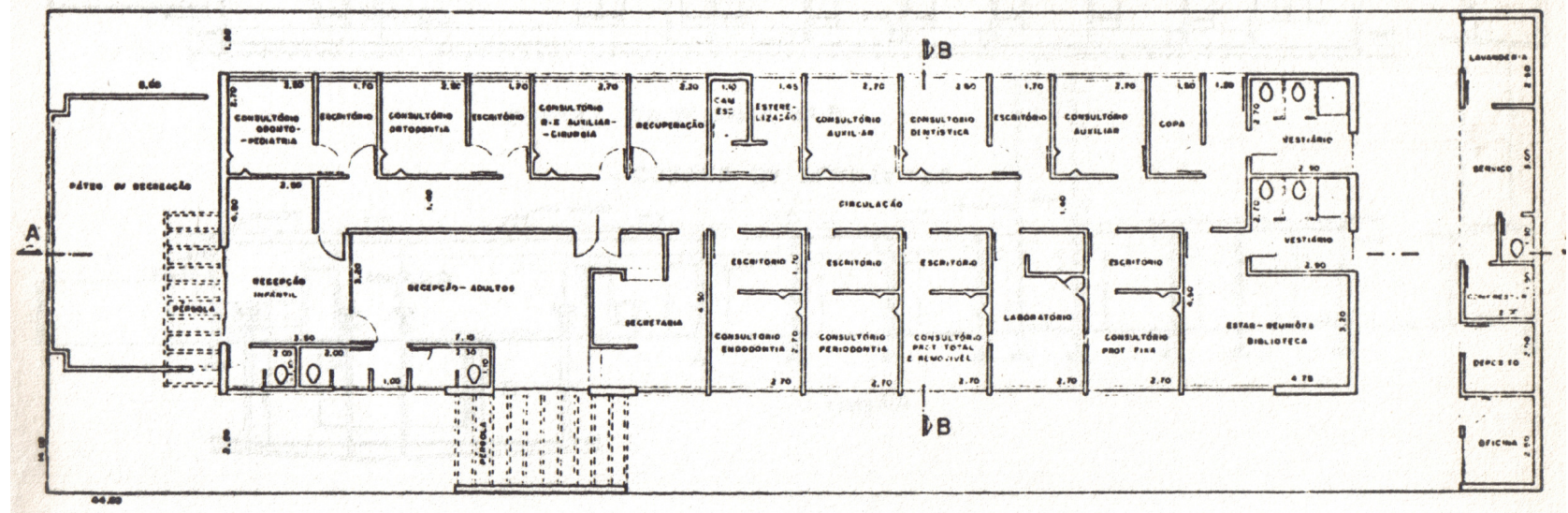

COE . Duas últimas versões de plantas feitas por Gastão. Fonte: PORTO (1975). È possível notar a edícula na planta final, solução que Gastão buscava evitar a todo custo. 
$\mathrm{Na}$ oportunidade, submetemos ao arquiteto escolhido os estudos que tínhamos em mãos para melhoria e apresentação de uma planta de execução da obra. ${ }^{28}$
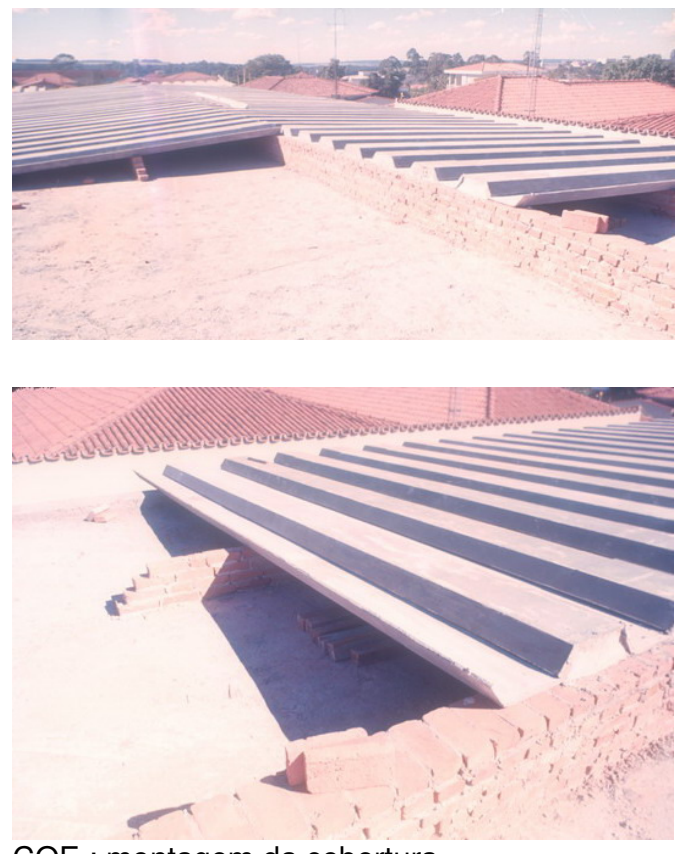

COE : montagem da cobertura. Fonte: acervo de slides COE
Foram elaborados diversos estudos a partir das plantas iniciais, onde Luiz Gastão foi aos poucos inserindo elementos de sua arquitetura, não só no efeito plástico, mas no que tange aos conceitos de acessibilidade, conforto e ergonomia.

A partir da análise das plantas apresentadas, nota-se a intervenção gradual do arquiteto principalmente na organização do espaço, buscando atender o corpo do centro odontológico em suas necessidades. Os desenhos revelam a inserção de conceitos de layout industrial levados à escala do consultório, fruto das experiências na Diamantul. A distribuição dos equipamentos e mobiliário também denota tal preocupação.

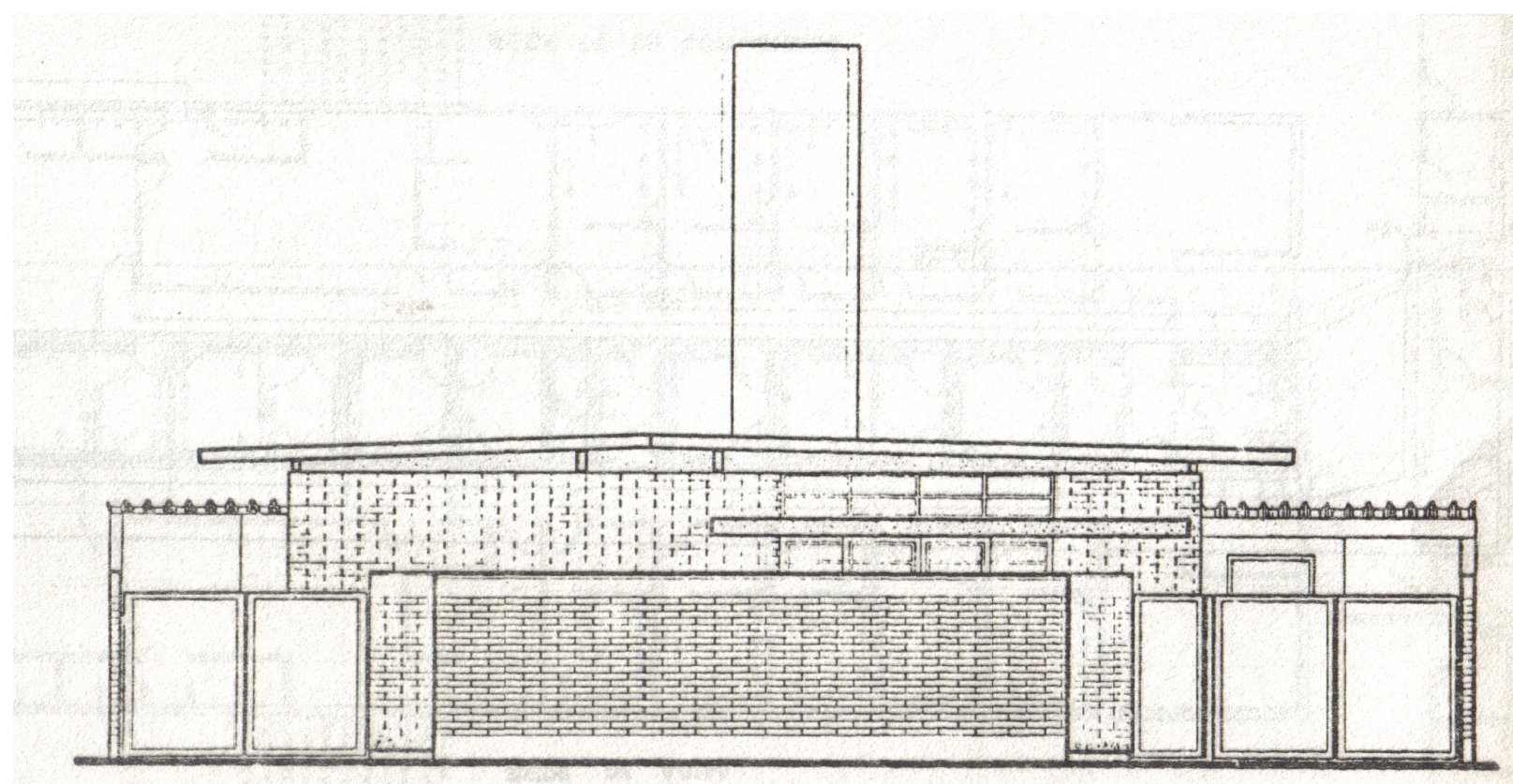

FACHADA DA PLANTA $n \div 9$

Fachada frontal COE. Centro Odontológico especializado. Fonte: PORTO (1975)

${ }^{28}$ PORTO, Fábio de Angelis. Estudos preliminares da planta de execução. In Odontologia de 

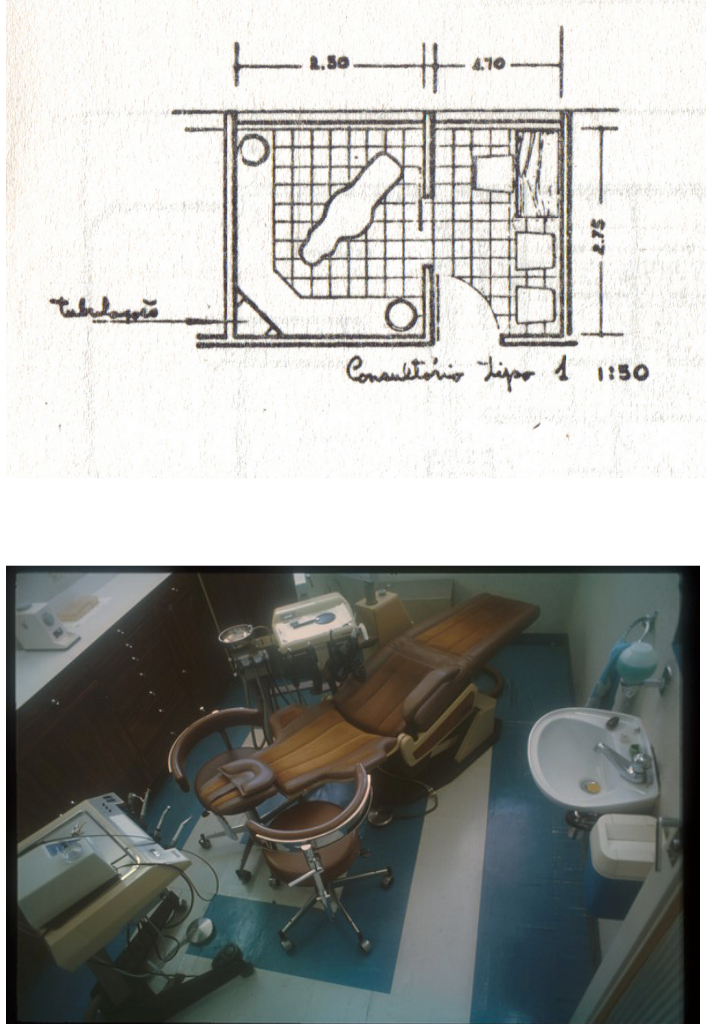

Lay out consultórios. Fonte: Foto: Acervo COE. Desenhos: PORTO (1975)

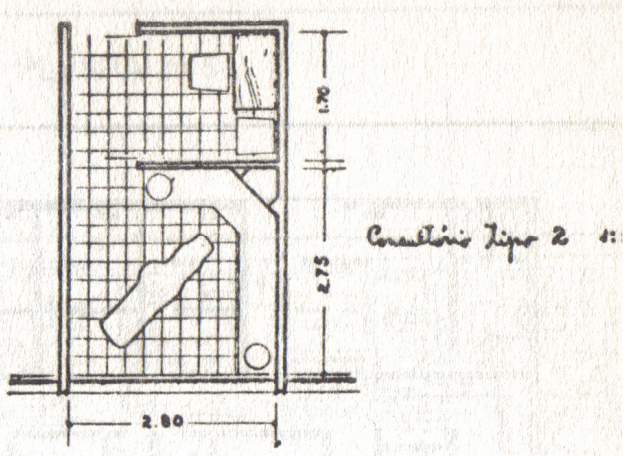

O projeto é pensado de forma a evitar o trânsito desnecessário a áreas de uso restrito, concentrando a odontopediatria na parte frontal do edifício, que no estudo inicial apresentado pela equipe médica se localizava na parte posterior.

Muitas das soluções dadas por Gastão foram incorporadas, outras negligenciadas durante a obra, a exemplo da supressão da iluminação zenital no corredor de acesso aos consultórios.

Durante a construção, o projeto sofreu algumas alterações e seria alvo de reformas posteriores que descaracterizaram a fachada da expressão original. Esta, de veia wrightiana, alcançava a horizontalidade a partir das linhas tênues da cobertura que por sua vez sugeriam leveza à fachada de tijolos à vista. A cobertura foi feita em placas pré-moldadas de concreto ou argamassa armada.

As floreiras surgem ancoradas aos muros frontal e lateral.A expressão wrightiana novamente é marcante no uso do tijolo, na horizontalidade e nos beirais pergolados, além de incorporar elementos reverberantes com a arquitetura paulista por meio do elemento vazado e da iluminação zenital. Esta, presente ao longo do corredor de 
circulação e acesso aos consultórios, foi abolida durante a execução da obra.
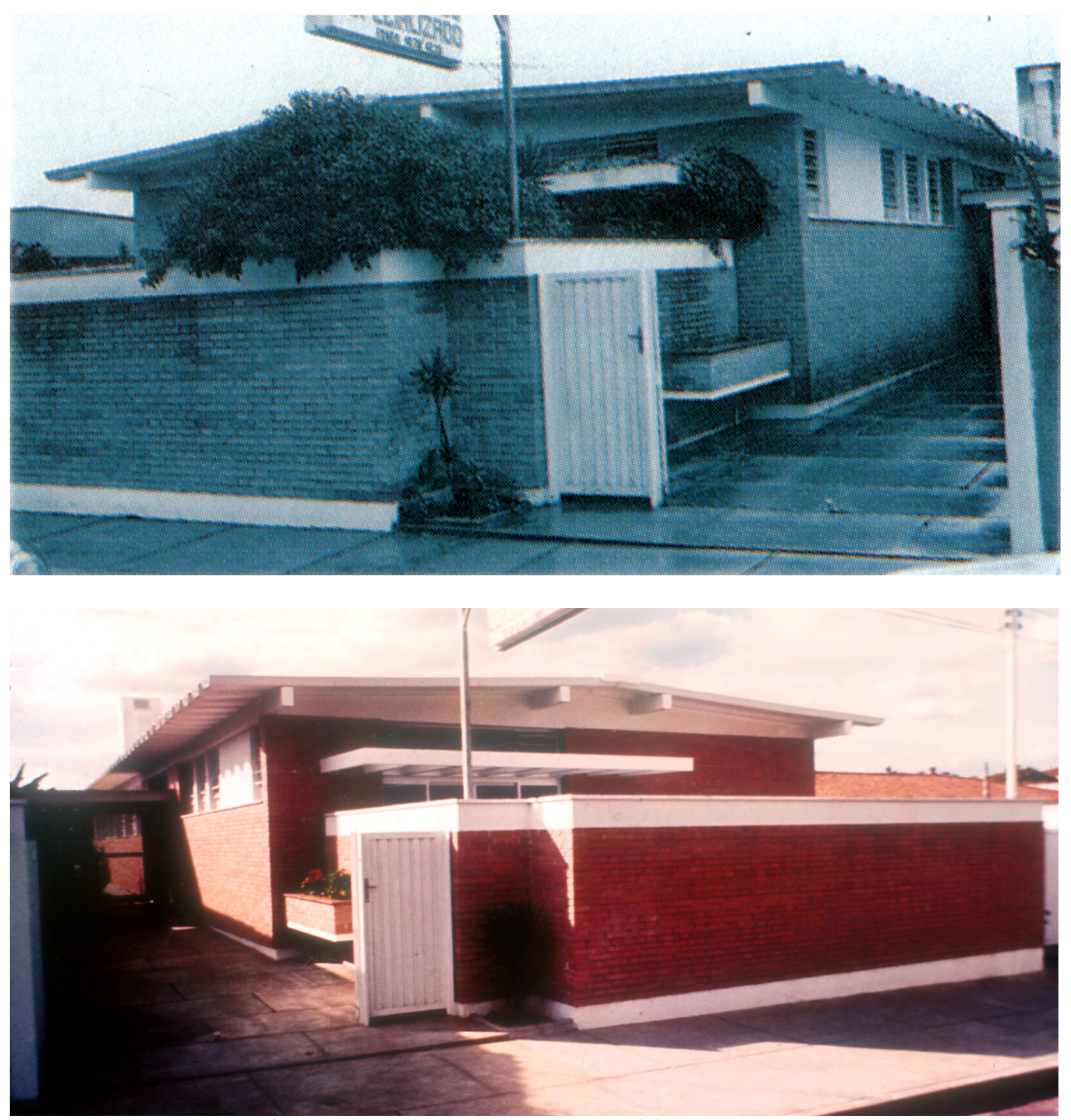

COE. Acima: fachadas na época da inauguração. Fonte: acervo COE
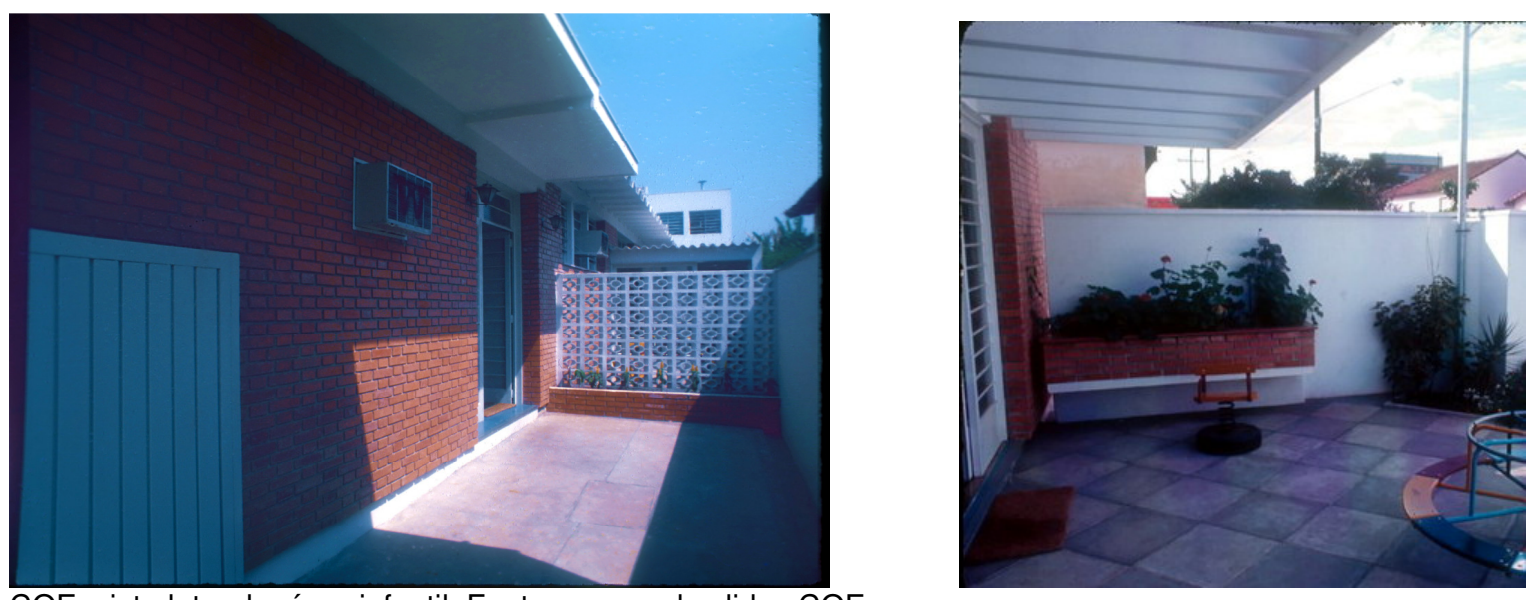


\section{Os projetos de Jaboticabal}
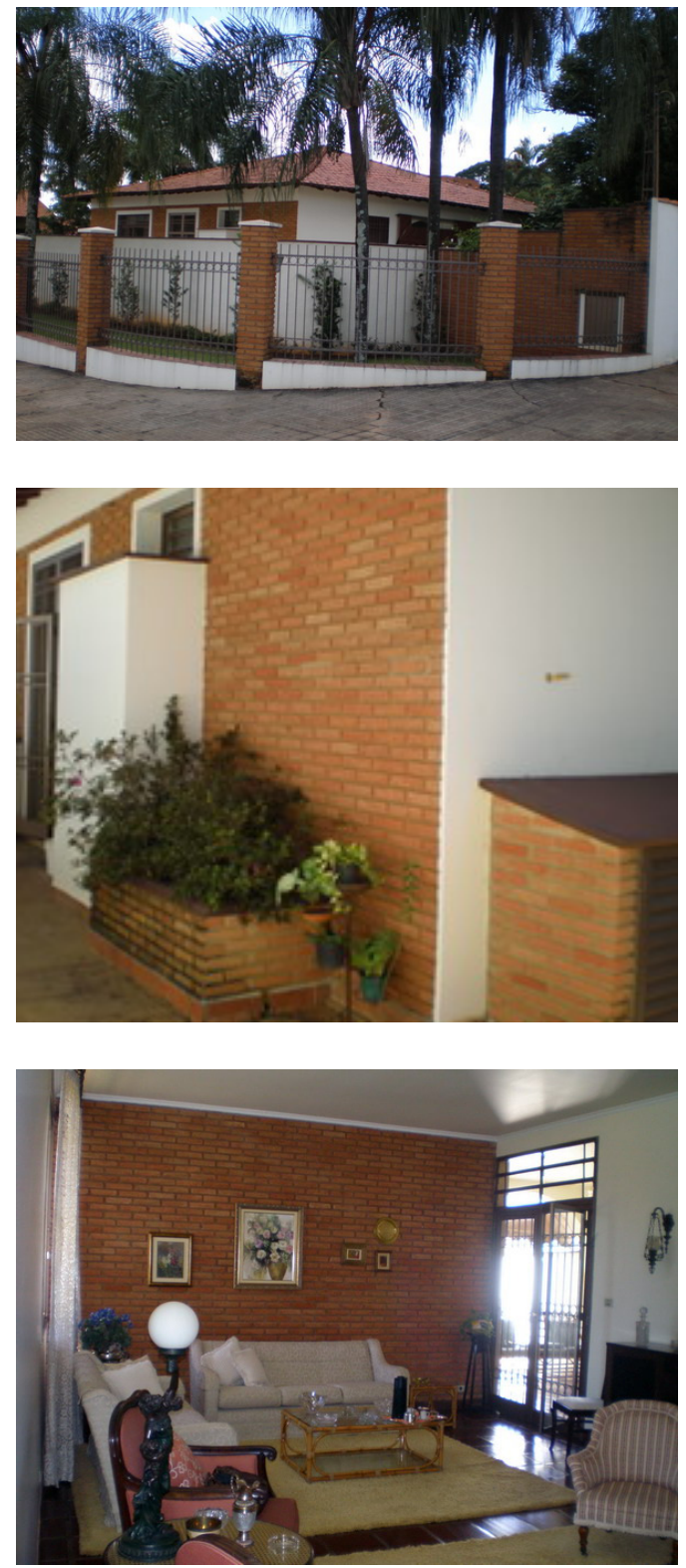

Casa Jamil Sader, Jaboticabal. Duas fotos acima: vistas externas. Abaixo: sala de estar. Fonte: fotos da autora
Em meados da década de 70, Luiz Gastão foi indicado por Ary Lolatto ao casal Maguita e Jamil Sader, para elaborar o projeto de sua residência em Jaboticabal no interior paulista.

$\mathrm{Na}$ época, a família de descendência árabe havia adquirido dois terrenos em um novo loteamento situado em área nobre da cidade. Obstetra, hoje profissional reconhecido internacionalmente na área médica e ex-prefeito de Jaboticabal, Jamil Sader dispunha na ocasião de recursos limitados para execução da obra. Esta andou devagar e tirou partido de materiais mais acessíveis, a exemplo da cobertura em telhas de fibrocimento; opção inicial que deu lugar às telhas cerâmicas em momento posterior. O tijolo à vista também era opção sempre que a idéia era diminuir custos.

O programa seguia a ordem de uma residência comum. O uso do tijolo aparente já não surpreendia tanto na fachada, mas não era prática comum em revestimentos internos, principalmente numa cidade do interior de hábitos tradicionais.

Me lembro que o Bispo esteve em visita à nossa casa e disse: "não entendo uma casa com a parede da sala em tijolo à vista". ${ }^{29}$

Gastão parece ter maior liberdade nas áreas menos nobres. $\mathrm{Na}$ residência de Jaboticabal, destaca o box do banheiro de serviços do corpo da casa, criando um volume mais baixo que permite locar o caixilho sobre este volume, privilegiando a entrada de luz na área central do ambiente. Arriscaria experiências desse tipo na volumetria dos 


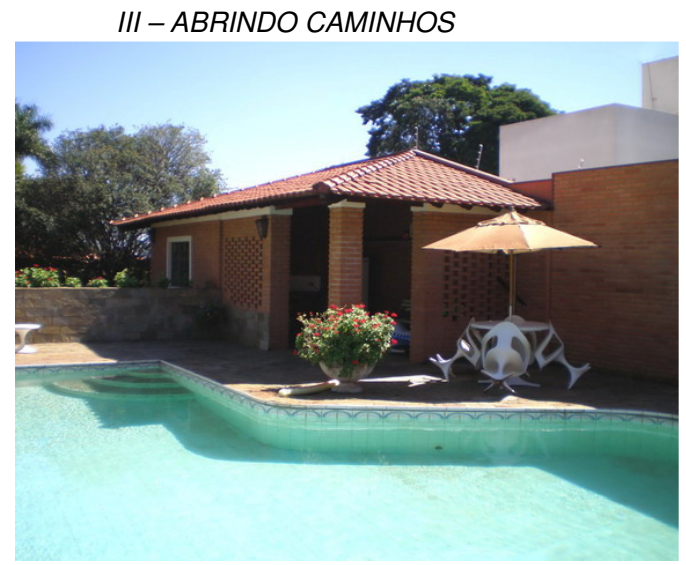

boxes dos banheiros da casa José Celso Contador (1968) e na sua própria residência (1974).

A churrasqueira expressa uma linguagem wrightiana mais evidente, não apenas no uso do tijolo, mas na dimensão dos beirais e na baixa inclinação do telhado. Bem ao estilo da casinha de Artigas (a primeira residência de 1942) é singela e delicada em suas proporções e incorpora aspectos

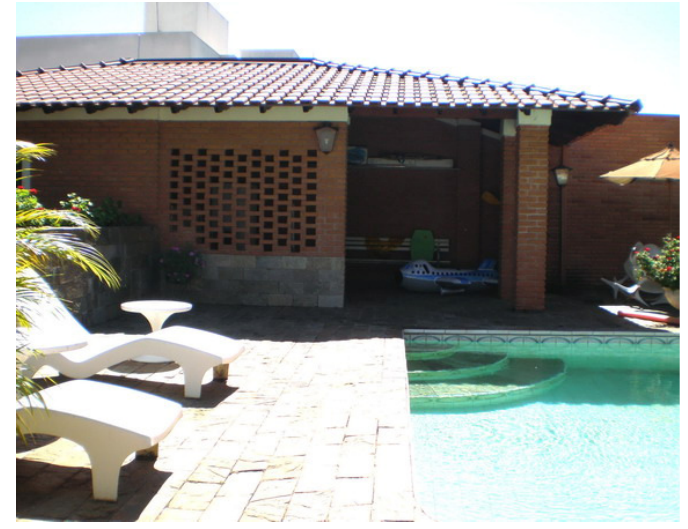
da arquitetura paulista no assentamento dos tijolos como elemento vazado.

A casa Jamil Sader se distribui de forma a valorizar o convívio íntimo familiar e se abre ao interior do lote, reservando à frente espaço para garagem, áreas de serviço e o pequeno consultório de entrada independente. Disposição pouco provável para o casal, foi vista com certas

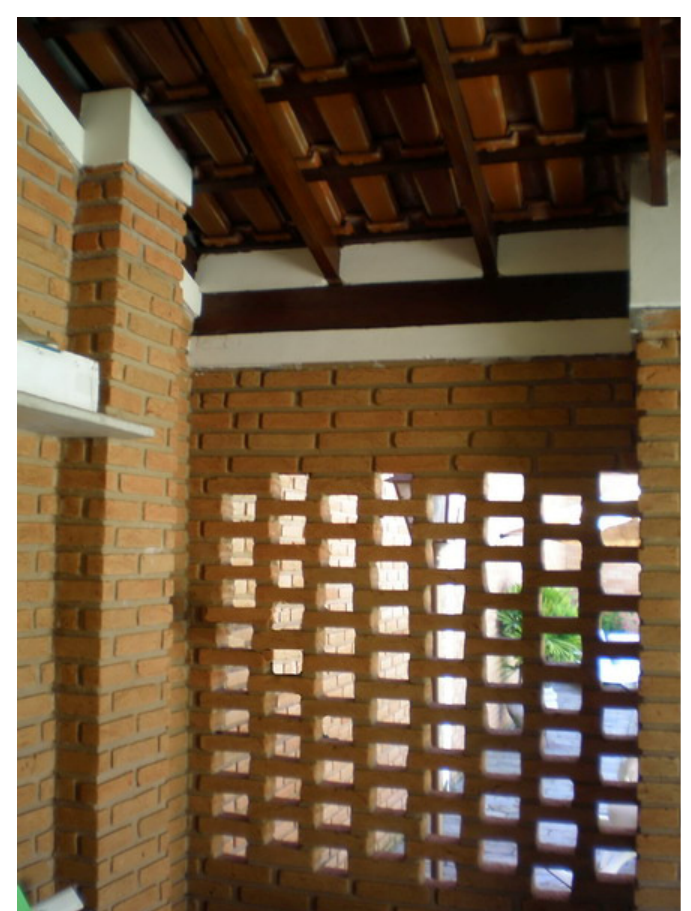
ressalvas.

Achei muito estranho quando vi a cozinha e a área de serviço assim, na frente da casa. Ele [Gastão] me disse: "não se preocupe Maguita, você se acostuma". 30

A solução em planta da casa Sader segue a linha do pensamento corbusiano presente nas concepções urbanísticas de Ville Verte, encampadas por Lúcio Costa no plano para Brasília e transpostas ao edifício na prática arquitetônica paulista durante a década de 60 . Nas palavras de Hugo Segawa, como crítica a valores e padrões burgueses, valoriza os espaços comunitários e Casa Jamil Sader, Jaboticabal. Duas fotos acima: piscina e churrasqueira. Abaixo: detalhes da churrasqueira. Fonte: fotos da autora compacta recantos privados. Sob este aspecto, Gastão dá indícios de uma ação reflexiva sobre Artigas.

\footnotetext{
${ }^{29}$ Maguita Sader em depoimento à autora em 16 de abril de 2008

${ }^{30}$ Idem, ibdem
} 

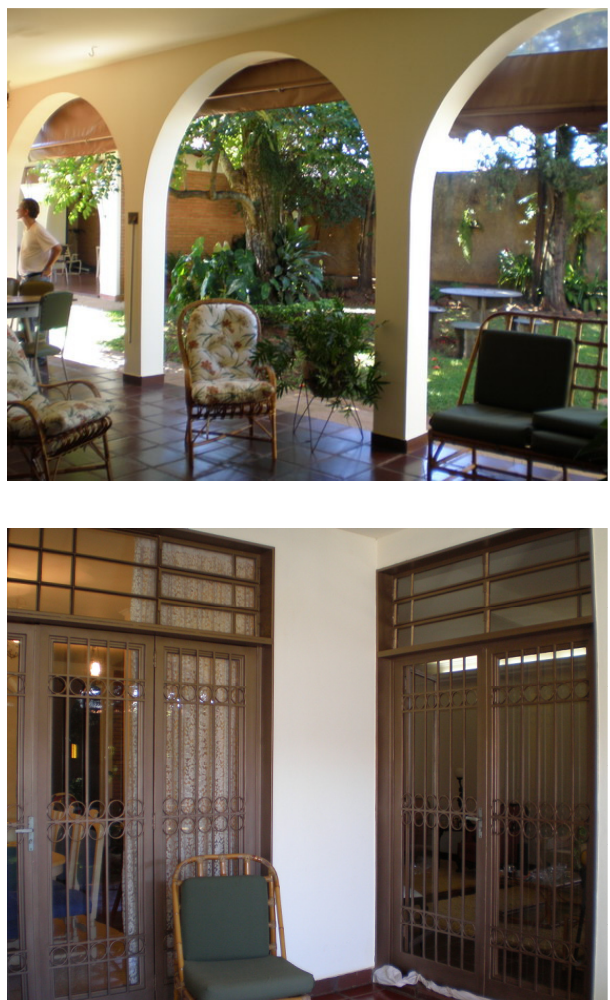

Casa Jamil Sader. detalhe da varanda posterior e caixilhos projetados pelo arquiteto. Fotos da autora.
A casa se articula em dois blocos que distinguem as funções dia/noite. A construção abre mão da lareira central, mas incorpora a idéia dos armários e estantes como divisores de ambientes e utiliza recursos de iluminação zenital. Estes pontos de luz que acontecem sobre o hall de circulação, receberam vitral desenhado pela proprietária.

Em vários projetos o arquiteto lançou mão dos arcos, em alguns deles usou arcos estruturais construídos em tijolos, como na casa Eugênio Cardinalli (1975). Muito provavelmente, a recorrência desse elemento se deva a um apreço pessoal, embora haja a possibilidade de referências remotas aos arcos richardsonianos presentes em alguns dos primeiros projetos de Wright.

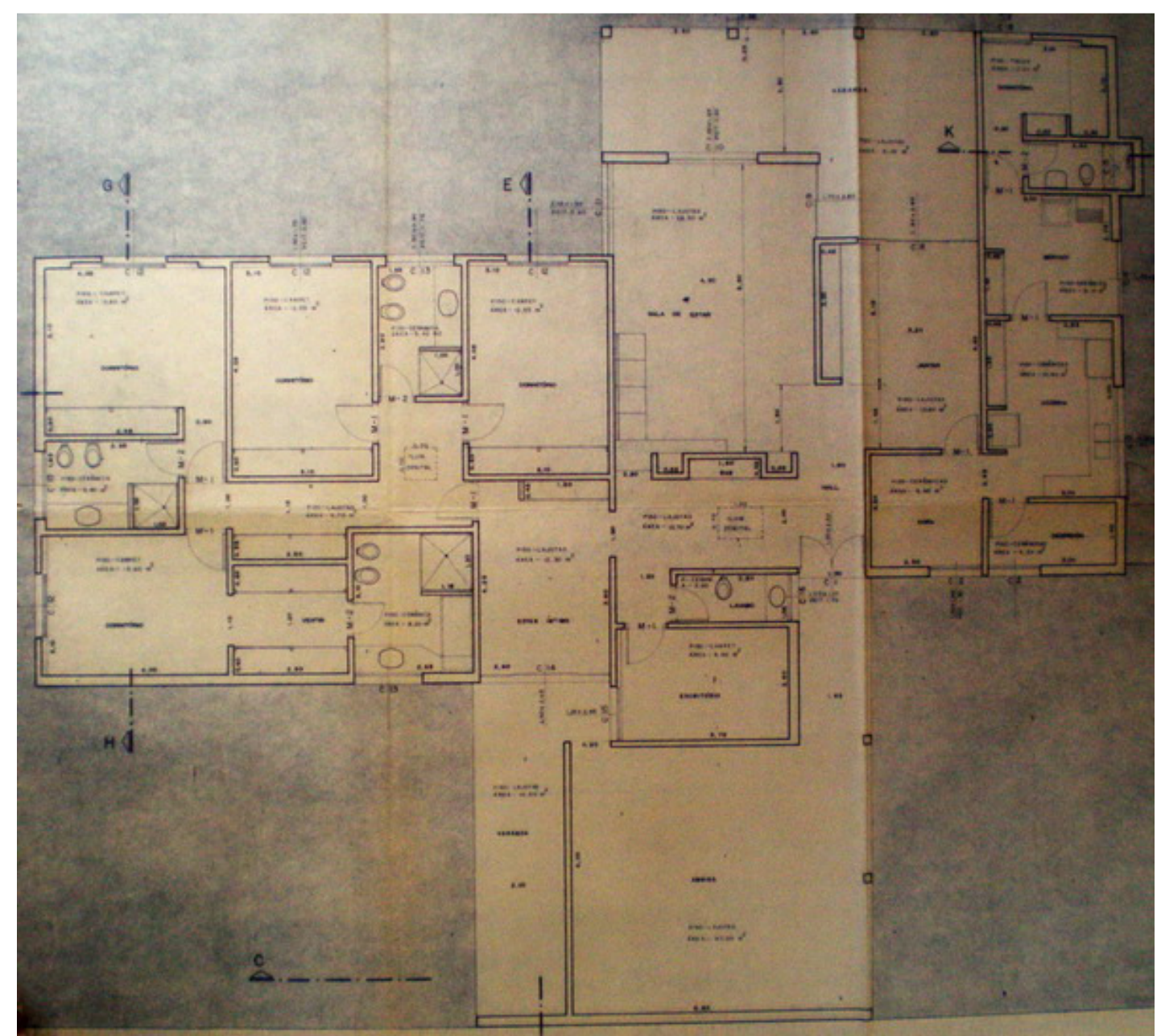



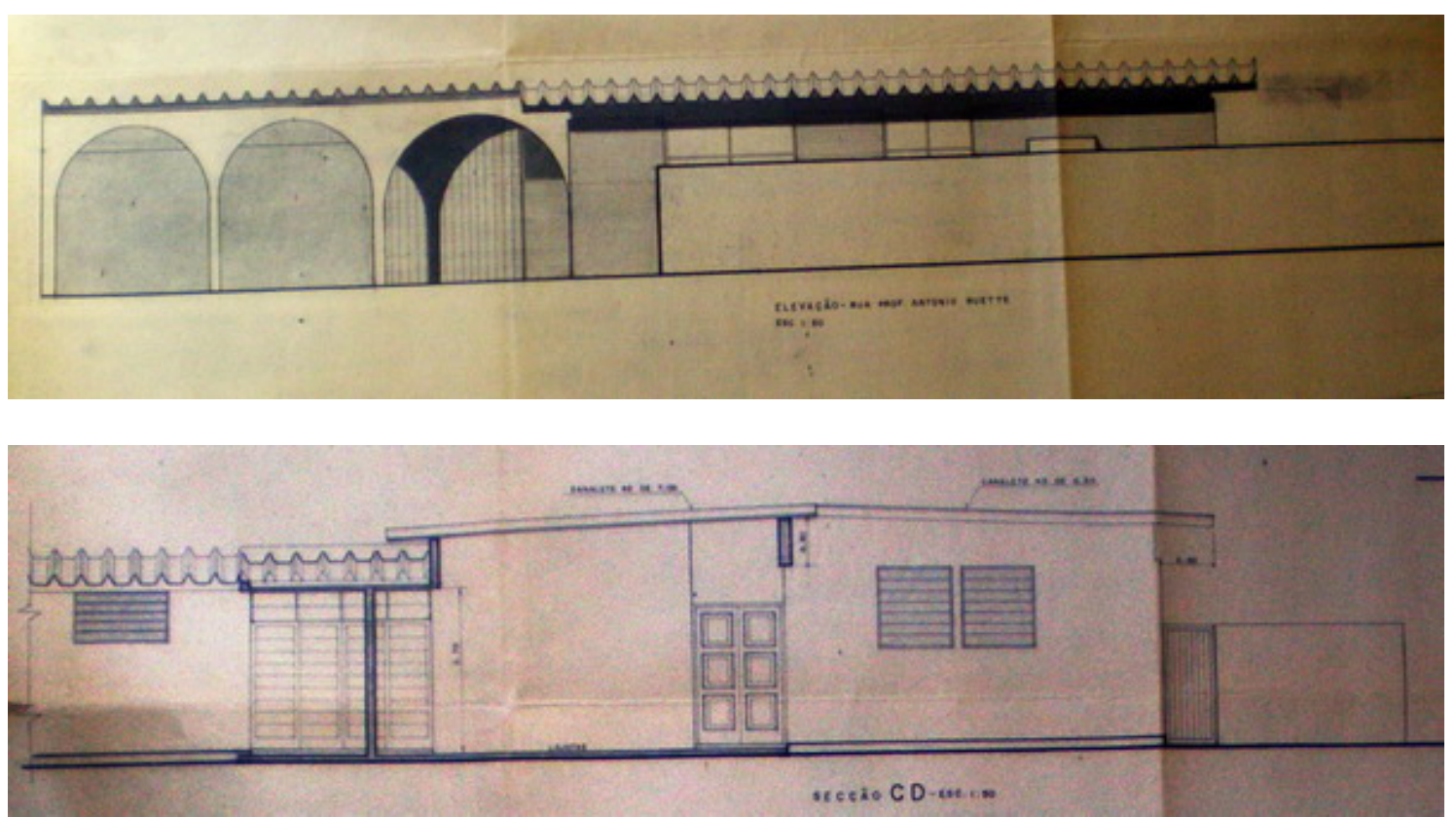

Casa Jamil Sader. elevação e corte. Fonte:acervo pessoal Jamil Sader.
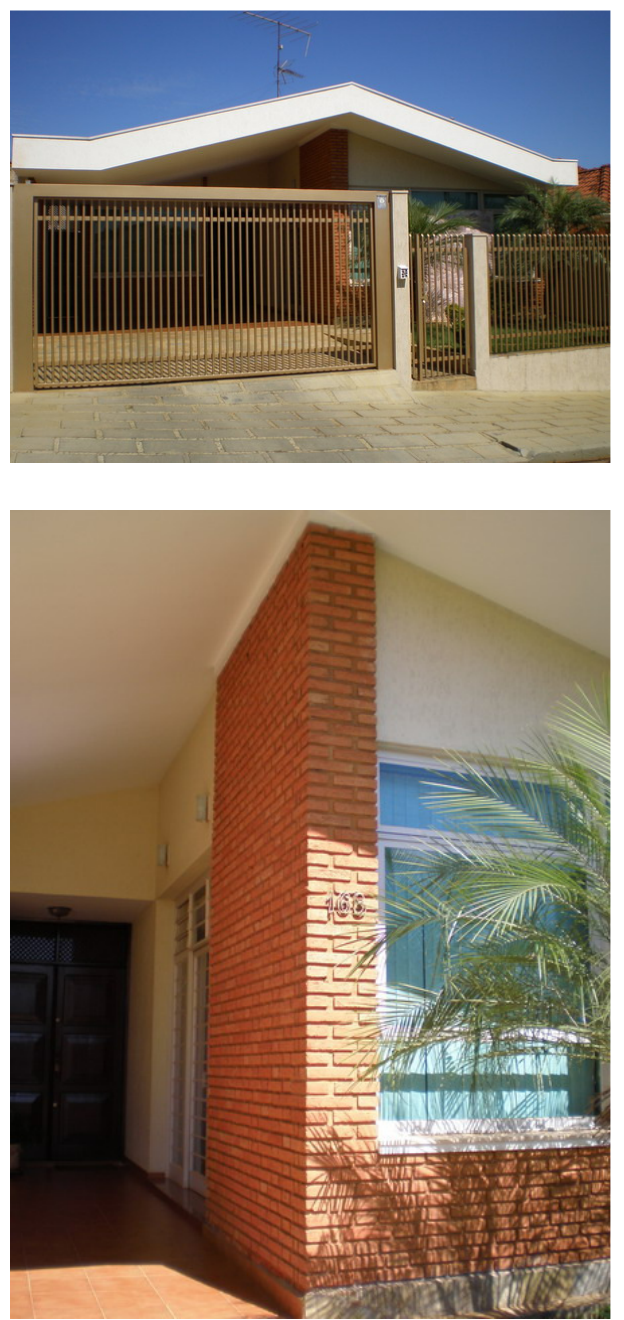

Casa Marry Junior. Jaboticabal. Fotos da autora
Ainda em Jaboticabal, Gastão elabora o projeto para o Hospital São Marcos e ainda durante as obras, uma casa na rua Marry Junior no 168 para um dos médicos ligados à área oftalmológica.

Não foi possível visitar a casa Marry Junior, mas na fachada a construção já demonstra proximidades formais e construtivas com grande parte do conjunto da obra de Luiz Gastão no uso do tijolo à vista e da cobertura única como pórtico.

O Projeto para o Hospital não surpreende com uma arquitetura arrojada do ponto de vista formal. Ao contrário, se mantém coerente tirando partido dos materiais disponíveis e de mão de obra local.

O conjunto hospitalar se organiza em um único piso, repousa sobre o terreno evitando movimentos de terra, intercalando os blocos através de suaves rampas escalonadas. A inclinação das rampas é tão imperceptível ao olhar quanto ao passo, marca registrada do arquiteto 

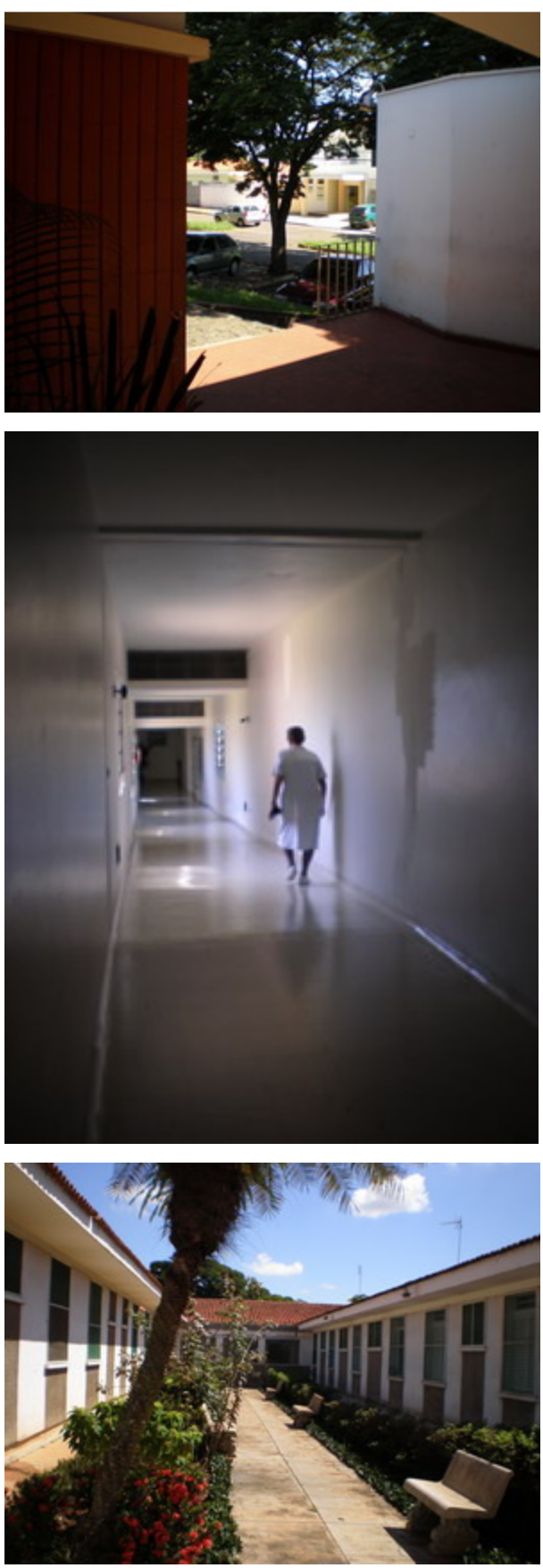

Hospital São Marcos Jaboticabal.

Acima: Vista de uma das entradas. Ao meio: rampa no corredor principal. Abaixo: vista de um dos pátios internos Fotos da autora.

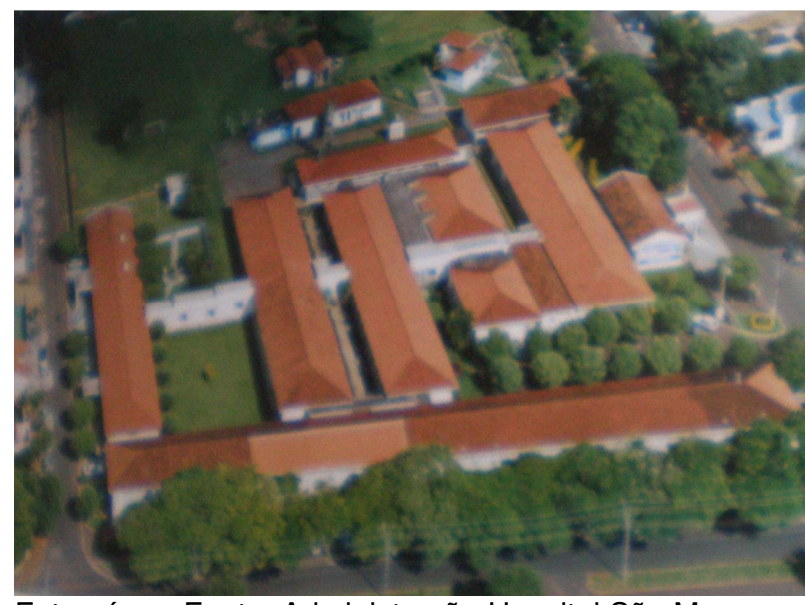

Foto aérea. Fonte: Administração Hospital São Marcos

A luz natural varre o edifício através de aberturas que dão acesso a diversos pátios internos. Um bloco central intercepta os demais perpendicularmente e concentra a circulação principal. Aberturas locadas junto à cobertura escalonada da rampa permitiam a entrada de uma luz difusa. Atualmente essas aberturas se encontram vedadas.

O edifício se distribui em blocos de atendimento interligados por um corredor central onde o acesso se dá por entradas independentes para cada setor. A idéia de setorização presente no projeto, segundo um dos administradores do hospital, revela a consciência do arquiteto ao conferir ao edifício uma característica que contribui na prevenção de infecções hospitalares.

Muitos médicos vêm do exterior imaginando encontrar um antigo prédio de cidade interiorana, escuro, mal distribuído e subutilizado. Todos, sem exceção, ficam surpresos ao ver como já havia sido pensado naquela época, um edifício dividido em blocos. $^{31}$

A solução de implantação em blocos articulados não era prática comum numa época em que a maioria dos edifícios erguidos para abrigar as casas de saúde era concebida em um corpo único.

\footnotetext{
${ }^{31}$ Declaração de um dos administradores do hospital durante nossa visita às suas instalações.
} 
UNESP

O ano de 1971 e os anos subseqüentes reservariam ao arquiteto alta carga de trabalho acadêmico e grande atuação profissional no desenvolvimento de mais de uma dezena de projetos, na sua maioria residenciais.

A partir de março, Gastão ingressa como professor adjunto na Escola de Engenharia da UNESP em Bauru ministrando as disciplinas Arquitetura e Construção de Edifícios, enquanto coordena o grupo de disciplinas de Programação Visual da FAU-USP. Gastão teve papel decisivo na UNESP, participando em 1988 do processo de implantação do Departamento Provisório de Arquitetura, Urbanismo e Paisagismo vinculado à Faculdade de Arquitetura, Artes e Comunicação. Como coordenador do Departamento, convida sua ex-orientanda, a arquiteta Maria Ângela Bortolucci e seu ex-colega na FAU, o arquiteto José Cláudio Gomes a integrarem o quadro docente da Escola.

"Graças a nós três, o departamento de Arquitetura, Urbanismo e Paisagismo pôde se consolidar, sair do provisório, pois já tinha três doutores." ${ }^{\text {32 }}$

A partir desse momento passa a ser cada vez mais marcante a ligação de Gastão à área tecnológica e aos estudos ligados à Comunicação e Programação Visual. É dessa época também a elaboração da logomarca para a construtora COCIBRA e os trabalhos de design Industrial e Comunicação Visual para a SAMBRA (Sociedade Anônima de Mármores). Consta em seu currículo que Gastão desenvolveu o projeto de um objeto de

\footnotetext{
${ }^{32}$ Maria Ângela Bortolucci em depoimento à autora.
} 


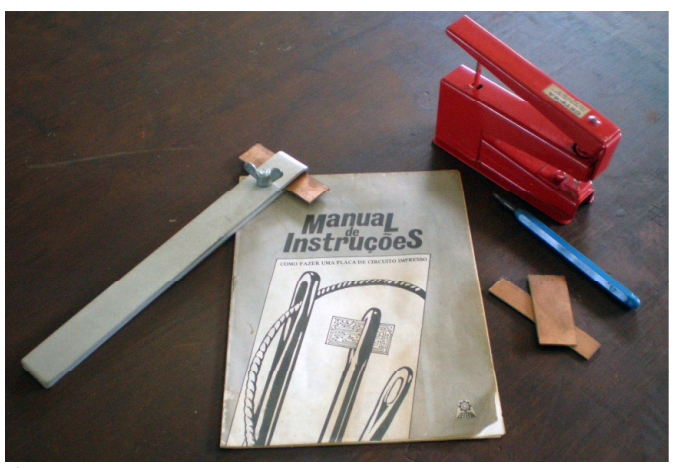

Objetos pessoais do arquiteto: Manual e ferramentas para montagem de circuito impresso. Fonte: acervo Luiz Gastão de Castro Lima. LIEP-UFSCAR. Foto da autora utilidade doméstica em mármore para a empresa. Infelizmente, esses trabalhos não puderam ser recuperados.

\section{A Universidade Federal de São Carlos e o LIEP}

Em 1976, Luiz Gastão inicia suas atividades na Universidade Federal de São Carlos (UFSCar), a convite do Reitor Luiz Edmundo Magalhães, que viu na contratação de equipes já constituídas, a possibilidade de implantar e incentivar a pesquisa na jovem instituição.

Um ano antes, a reitoria designava uma comissão de estudos a fim de iniciar a implantação de cursos de pós-graduação na UFSCar. Constituiu-se a partir daí, o primeiro órgão colegiado "ad-hoc", prestando assessoria à pósgraduação num período em que o Conselho de Ensino e Pesquisa (CEPE) ainda não havia sido efetivado.

Gastão é contratado nesse momento, a princípio como assessor da reitoria. O campus estava em vias de expansão e havia a necessidade de elaboração de projetos de arquitetura para as novas instalações, para tal se formou o escritório de desenvolvimento físico que na época se chamava ASPLAN (Assessoria de Planejamento). Em 79, é transferido da reitoria para o Departamento de Engenharia de Produção como professor adjunto, ficando vinculado à Instituição até 1995. Não há registros de projetos desenvolvidos pelo arquiteto junto à ASPLAN, apenas o testemunho de pessoas ligadas ao departamento, de que o arquiteto, ao lado de alunos do curso de produção, teria 

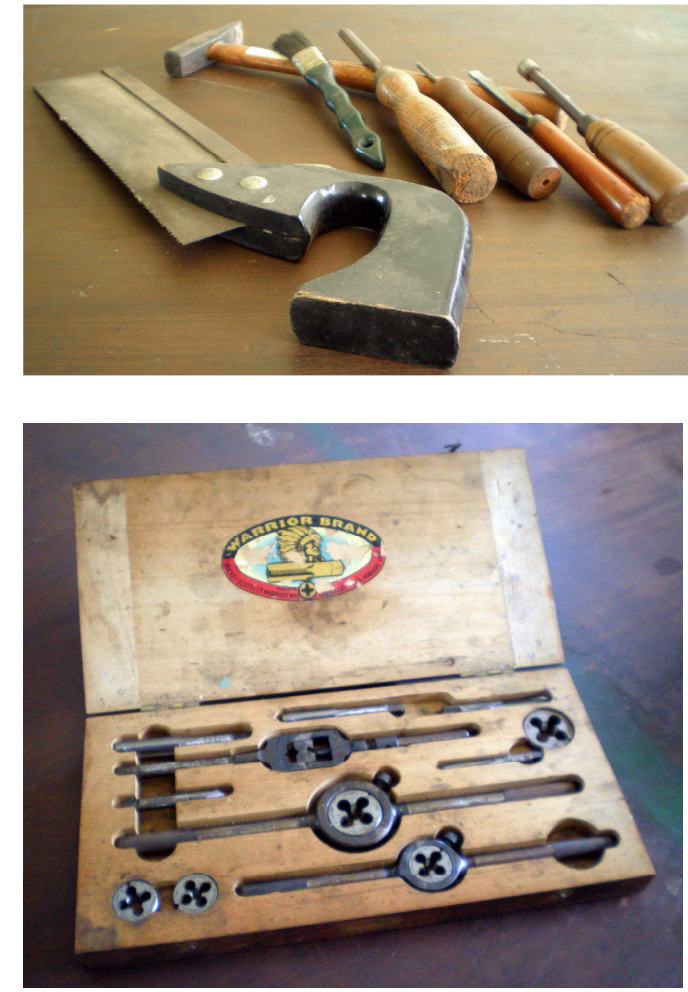

Objetos pessoais do arquiteto: Ferramentas de Luiz Gastão. Acervo Luiz Gastão de Castro Lima. LIEP-UFSCAR. Foto da autora. desenvolvido o projeto para o laboratório integrado (LIEP).

$\mathrm{Na}$ ocasião, já havia sido aberta a primeira turma do curso, mas ainda estavam por ser dadas as disciplinas de Projeto. Buscando atender às recomendações levadas ao MEC pela Secretaria de Tecnologia Industrial do Ministério da Indústria e Comércio, Gastão elabora uma proposta para o curso, ressaltando a importância de estruturá-lo com foco na produção e criação de tecnologia.

Neste primeiro manuscrito, Gastão coloca a importância do projeto do produto e destaca uma postura de afastamento por parte dos engenheiros em relação à prática projetual. Essa linha de raciocínio defendida por Gastão de aproximar o profissional da prática de projeto é ainda uma das diretrizes principais do curso de Engenharia de Produção da UFSCar.

A estruturação das disciplinas de projeto exposta pelo arquiteto procurava orientar o curso dentro de uma linha conciliatória entre a Engenharia de Produção e o Desenho do Produto, incluindo matérias de formação básica (desenho técnico, tecnologia mecânica e comunicação visual) e matérias de formação geral (tecnologia e mudança social, sociologia e psicologia da percepção).

No manuscrito, Gastão dá ênfase à formação profissional geral e específica, atribuindo disciplinas de abordagem técnica (materiais ferrosos e não ferrosos, polímeros e métodos de conformação) e disciplinas de caráter prático (processos industriais, metodologia, ergonomia, etc). Insere como essencial a prática de laboratório desde o início da formação, induzindo o aluno a uma oficina de 
desenho e produção e alerta para a necessidade de um estudo aprofundado de ergonomia.

"Consideramos da maior importância a ergonomia, pois ainda não existe uma escola brasileira de ergonomia. Toda experiência que adotamos é importada, baseada portanto em padrões físicos e de comportamento completamente diferentes daqueles do homem brasileiro." ${ }^{33}$

Com uma visão abrangente de todo o processo de produção, fruto inclusive de sua atuação junto à Dimanatul, buscava demonstrar a importância das pesquisas de base tecnológica e a necessidade de se investir na formação de um profissional visando o mercado internacional.

\begin{abstract}
A partir da idéia fundamental de que o processo de substituição das importações, o crescimento do mercado nacional e o esforço de competição no mercado internacional exigirão, por parte da indústria nacional de bens e equipamentos, um grande esforço no sentido de criação de tecnologia, pode-se deduzir a necessidade urgente de desenvolvimento de pesquisas na área das ciências exatas, pesquisas orientadas com 0 objetivo de permitir rebatimento tecnológico eficaz. ${ }^{34}$
\end{abstract}

Chamava ainda a atenção para a necessidade de se estabelecer uma integração com as indústrias regionais a fim de se promover estágios e desenvolver projetos em conjunto com grupos de trabalho da Universidade, criando uma sistemática de integração empresa-escola. Esse

\footnotetext{
${ }^{33}$ Luiz Gastão de Castro Lima. Manuscrito da Proposta para o curso de Engenharia de Produção, especialidade Engenharia do Produto. Acervo do arquiteto. LIEP-UFSCar
} 

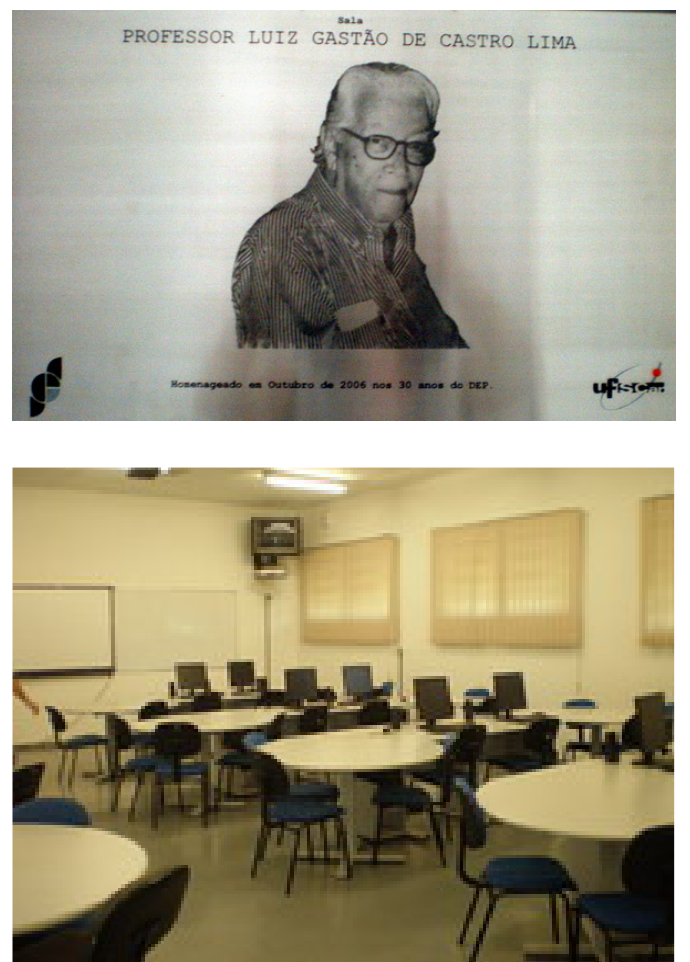

Sala Professor Luiz Gastão de Castro Lima. LIEP.DEP. UFSCar

Homenagem recebida em outubro de 2006 sistema cooperativista favoreceria a indústria que aproveitaria a tecnologia desenvolvida na Universidade e favoreceria a Universidade, que teria campo para aplicação do conhecimento gerado.

As disciplinas de projeto do curso de Engenharia de Produção da UFSCar foram criadas a partir das bases expostas neste manuscrito, visando a união de tecnologia em processamento de materiais cerâmicos, siderúrgicos e poliméricos com a gestão de processos industriais. Essa base inicial descrita por Luiz Gastão tem norteado até hoje o Departamento.

Com foco nesses princípios, Luiz Gastão cria - LIEP (Laboratório Integrado de Engenharia de Produção - Laboratório do Produto) buscando a formação continuada de um profissional que reunisse aptidões para as ciências exatas e as ciências humanas. A partir daí as disciplinas de projeto se estabelecem: Projeto do Produto, Projeto do Trabalho e Projeto de Fábrica. Apoiadas na infra-estrutura do LIEP foram desenvolvidas atividades práticas de confecção de maquetes, simulação de projetos de fábricas e exercícios avaliativos de tempos e métodos.

A contribuição de Luiz Gastão junto ao curso de Produção é sensível até hoje. Há três anos recebeu homenagem da Instituição com uma sala em seu nome nas instalações do LIEP. O departamento hoje abriga o acervo pessoal do arquiteto, ainda em fase de organização e catalogação.

\footnotetext{
${ }^{34}$ Luiz Gastão de Castro Lima. Manuscrito da Proposta para o curso de Engenharia de Produção, especialidade Engenharia do Produto.
} 

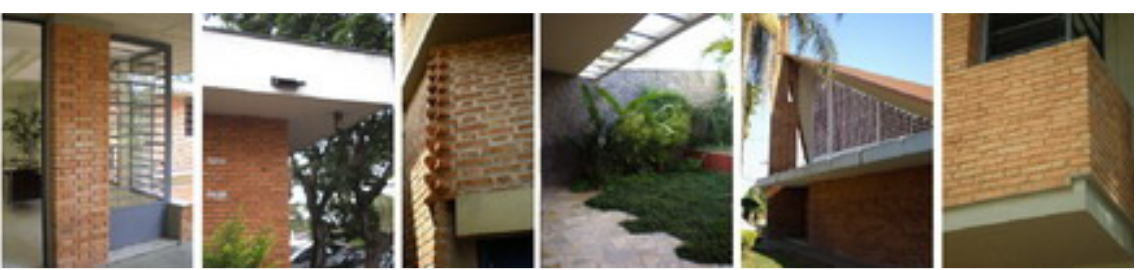
${ }^{1}$ Apud McCARTER, Robert. Frank Lloyd Wright, 1999. pg 14. 
Aproximações a Frank Lloyd Wright são notáveis em muitos projetos de Luiz Gastão, mas chamá-lo simplesmente wrightiano seria reduzir sua obra e correríamos o grave risco de limitar uma análise, sem vislumbrar os múltiplos conceitos que ela encerra. Outras influências em Gastão podem ser associadas a Charles Rennie Mackintosh, até mesmo pela relação de sua arquitetura com a de Frank Lloyd Wright e não podemos descartar a fase brutalista da escola paulista, que terá seu momento em algumas obras de Luiz Gastão assim como em muitos dos seus contemporâneos.

Assim como o organicismo, o termo brutalismo oferece escassa documentação e as fontes existentes permanecem limitadas a análises do texto de Banham, embora recentemente Ruth Verde Zein tenha dado novas interpretações a esse mesmo texto e contextualizado a fase paulista do brutalismo dentro de uma análise global. $^{2}$

Partindo de Corbusier nas obras posteriores à segunda guerra, mais precisamente na Unidade Habitacional de Marselha (1952) ou da difusão das idéias defendidas pelo casal Smithson, certas arquiteturas de proximidade plástica, construtiva e formal se proliferaram quase que simultaneamente por diversos países e encontraram na São Paulo dos anos 50-70 terreno fértil para ações significativas. $O$ uso do material bruto, sem revestimento, principalmente do concreto aparente

2 BANHAM, Reyner. El Brutalismo em Arquitectura. Etica o Estética?. Barcelona, Gustavo Gili, 1967 e ZEIN, Ruth Verde. Brutalismo, sobre sua definição (ou, de como um rótulo superficial é, por isso mesmo, adequado). Arquitextos Vitruvius. Acessível em http://www.vitruvius.com.br/arquitextos/arq084/arq084_00.asp 
que caracteriza essa produção particular estaria também associado à exploração tecnológica do béton brut. Dentre elas, se destacam as experiências com 0 uso de coberturas em abóbadas realizadas por Sérgio Ferro, Flávio Império, Rodrigo Lefèvre, Joaquim Guedes, Eduardo de Almeida, Pedro Antônio Cury, dentre outros.

Nome de menor repercussão que os demais citados, Pedro Cury é autor da casa Coriolano Meireles construída em São Carlos em 1971. Fruto de projeto com forte expressão plástica, dialoga formalmente com a casa Bernardo Issler de Sérgio Ferro erguida dez anos antes. A casa Meireles por vezes teve sua autoria atribuída a Luiz Gastão, mas apesar de grande amigo da família, Gastão não teve participação no projeto. 


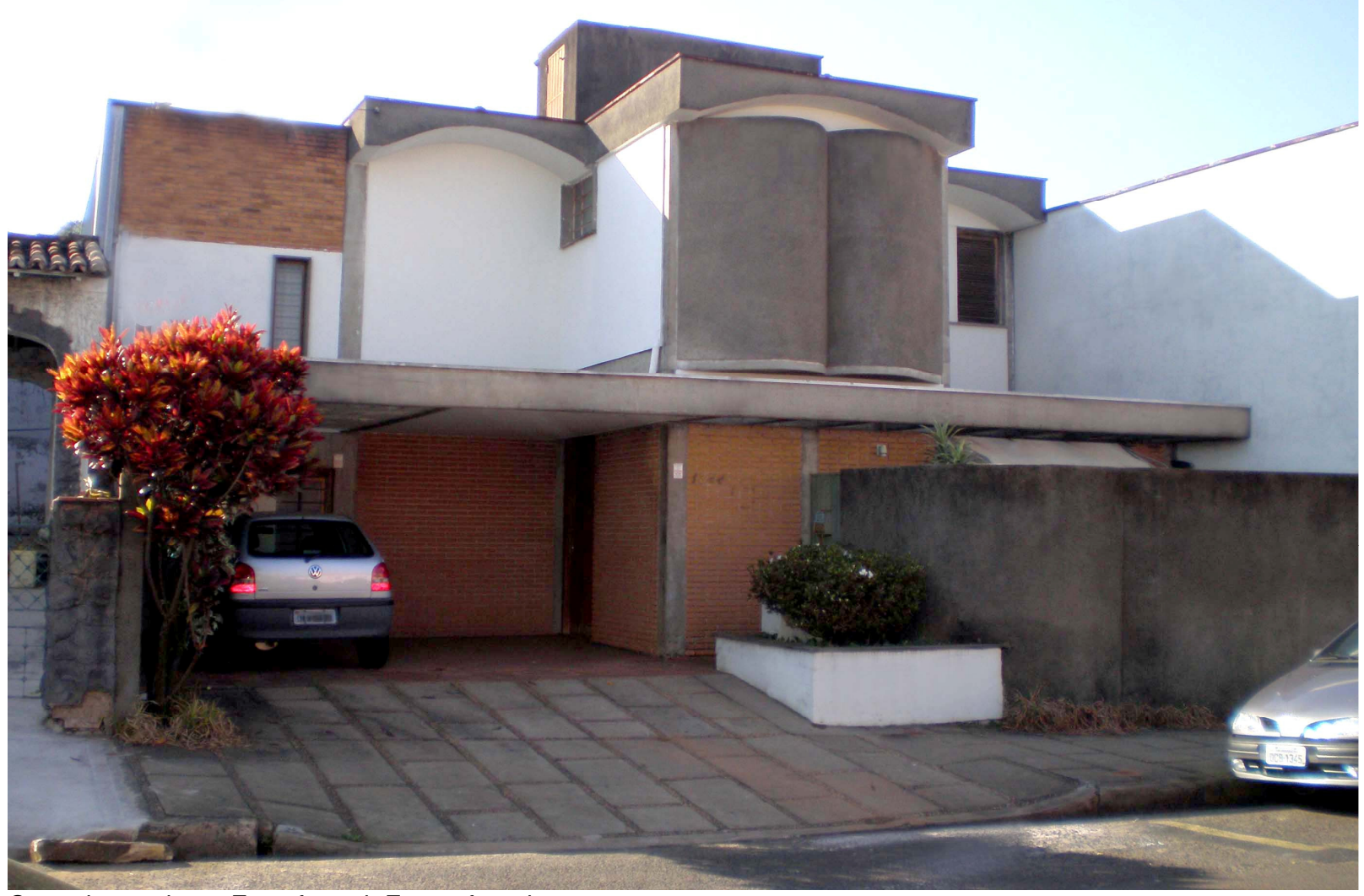

Casa do arquiteto. Face frontal. Fonte: foto da autora

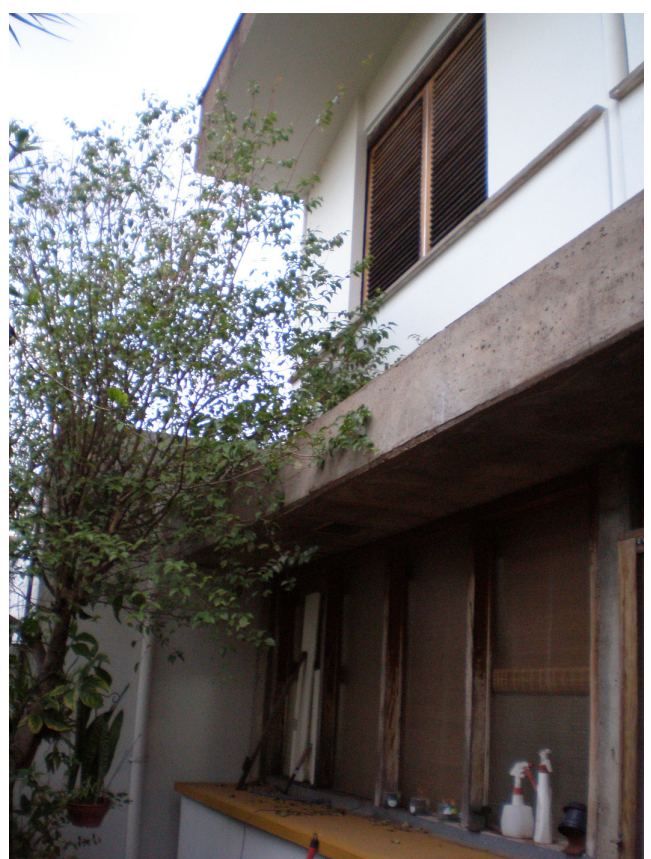

Residência do arquiteto- 1973

Projeto de 1973, a residência do arquiteto foi implantada num terreno de dimensões reduzidas, em área desmembrada de maneira incomum para um lote urbano. O programa envolve dois dormitórios, estúdio e oficina em uma área restrita a doze metros de frente e quinze de profundidade. Assim como os arquitetos ligados ao grupo Arquitetura Nova, Gastão demonstra habilidade em resolver a moradia em pouco espaço com uso de Casa do arquiteto. Face posterior. Fonte: foto formas não convencionais. ${ }^{3}$ da autora

${ }^{3}$ Sobre os arquitetos Sérgio Ferro, Rodrigo Lefèvre e Flávio Império, ver KOURY, Ana Paula. Grupo Arquitetura Nova. Dissertação de Mestrado, EESC-USP, 1999. e o livro da mesma autora Grupo Arquitetura Nova. Flávio Império, Rodrigo Lefèvre e Sérgio Ferro. Romano Guerra. Edusp, 2003. 

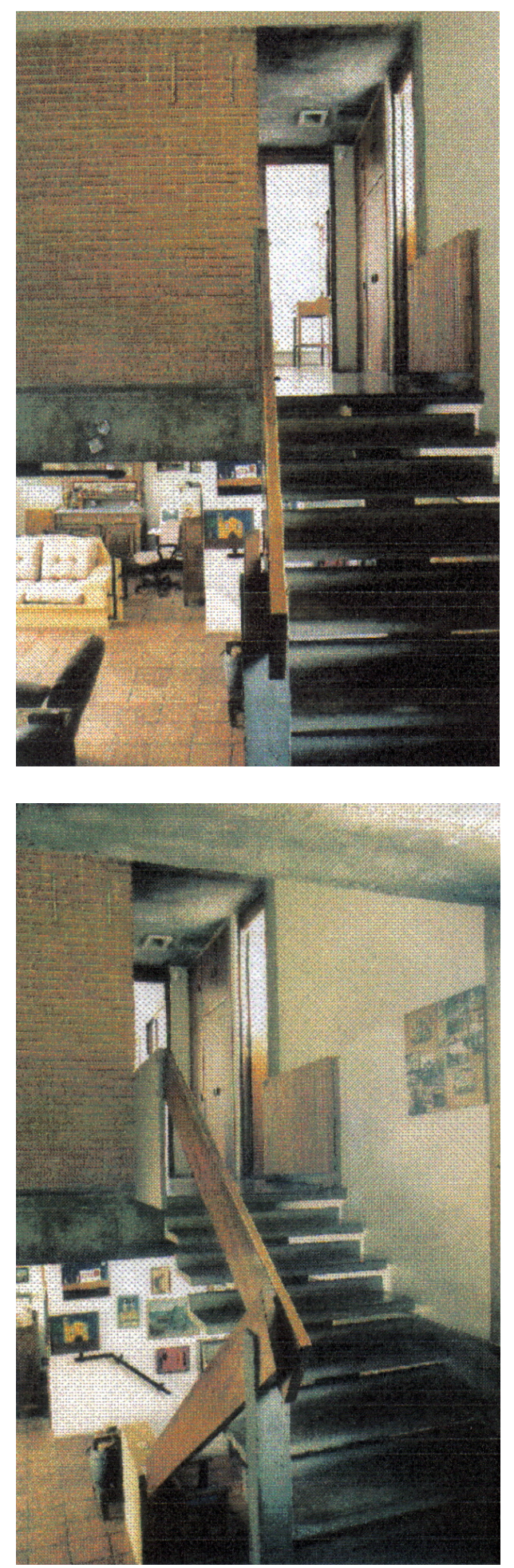

Casa Luiz Gastão de Castro Lima. Vistas internas. Fonte: Fundação Pró Memória de São Carlos
A partir da lareira, a casa se articula em dois níveis principais entremeados por níveis intermediários. Ao nível da entrada se localiza a garagem, serviços, lavabo e hall, alguns degraus acima, o estar e jardim social. Em nível intermediário, o estúdio que abrigou durante muitos anos o ateliê de projetos do arquiteto e no nível superior: a área íntima e dormitórios.

Há ainda dois outros níveis, um abaixo do estúdio designado como estar privativo, onde Gastão mantinha sua pequena oficina e um solário acima do mesmo estúdio acessível por uma escada caracol que não consta no projeto original.

O aproveitamento do terreno é total. Dos $187,20 \mathrm{~m}^{2}$ a casa ocupa $177,20 \mathrm{~m}^{2}$.

Mais uma vez, há a presença de uma linha horizontal que intercepta o conjunto seccionando pavimento térreo e superior.

Gastão arrisca experiências interessantes como o volume circular dos boxes dos banheiros destacados da fachada. Já havia utilizado recurso similar anos antes, nas casas Jamil Sader e José Celso Contador. A forma curva se repete no muro. Podemos notar em outros projetos do arquiteto, a presença recorrente de um elemento circular na fachada, muitas vezes como floreiras, onde Gastão lança mão da linha curva em contraponto à geometria de linhas retas do edifício.

A cobertura se dá a partir de três abóbadas com $3 \mathrm{~m}$ de vão, erguidas diretamente sobre paredes de alvenaria. As abóbadas estão presentes tanto na cobertura onde recebem uma camada em argila expandida como na laje de piso do pavimento superior, onde sobre camada em concreto foi instalado piso tipo durafloor. 
As abóbadas têm seu referencial nas Maison Jaoul de Corbusier, primeiro exemplar desse tipo de solução, que deu margem a inúmeras variações posteriores dentro da escola paulista.

Sempre que possível Gastão também projetava o mobiliário em alvenaria, de forma a obter maior domínio sobre o layout e definir o uso do espaço, além de promover economia na compra de mobiliário. Aqui, desenhou o mobiliário dos quartos, banheiros, cozinha, área de serviços, sala e lareira. Na cozinha, a iluminação é embutida na laje, dispensando instalação de luminárias.
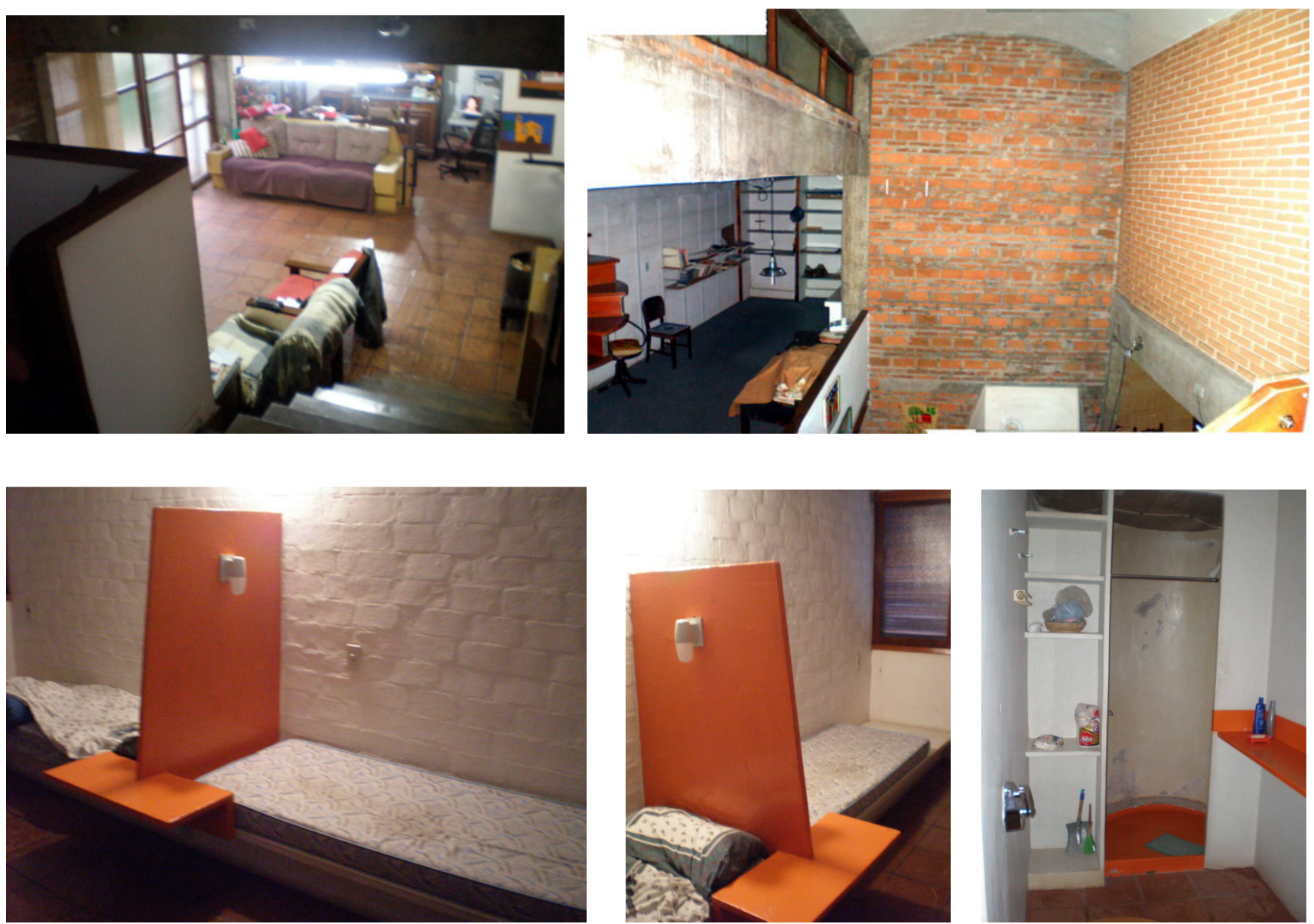

Vistas internas. Residência Luiz Gastão de Castro Lima. Fotos da autora 


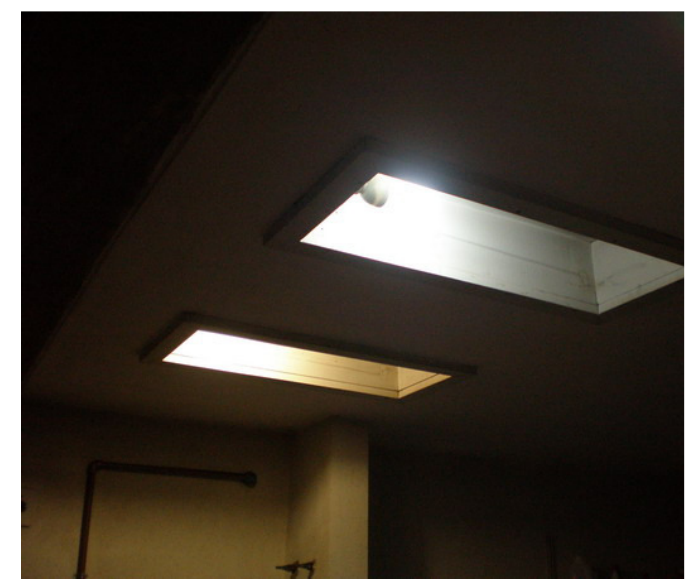

Residência Luiz Gastão de Castro Lima. Calha de iluminação embutida na laje da cozinha. Foto da autora
O aproveitamento racional dos dormitórios previa espaço de repouso e trabalho. As camas em concreto são interceptadas por duas lâminas: uma vertical (separa as duas camas como cabeceira) e outra horizontal (serve como apoio lateral dispensando o criado mudo).

A iluminação do quarto se dá por meio de arandelas instaladas na alvenaria e na lâmina vertical, permitindo criar ambiente de leitura. $\mathrm{O}$ armário embutido tem divisão intermediária e dispensa as portas. A exemplo das usonian houses, a rede hidráulica é concentrada em único núcleo (linha hidráulica) como medida de redução de custos.

Em vários ambientes a pintura foi aplicada diretamente sobre a alvenaria sem reboco, mantendo a textura do tijolo usado como material de vedação.
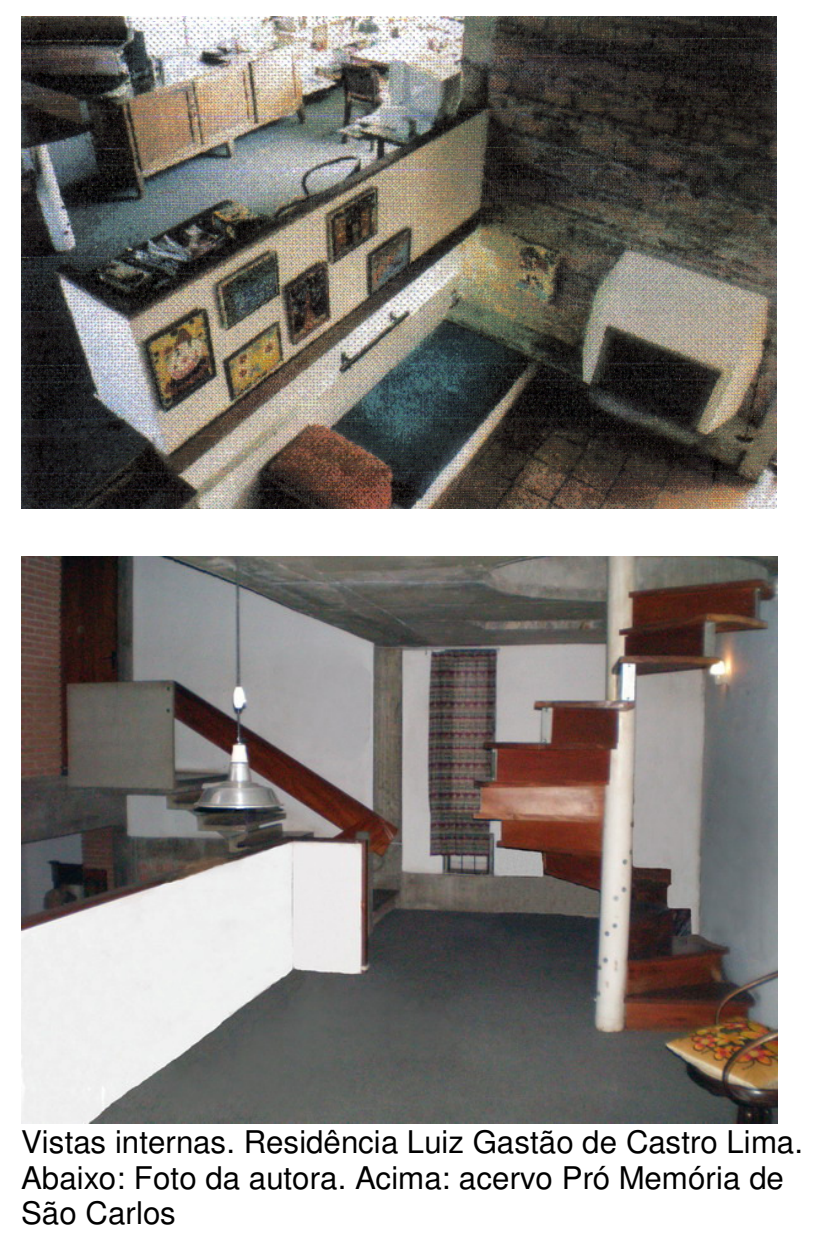


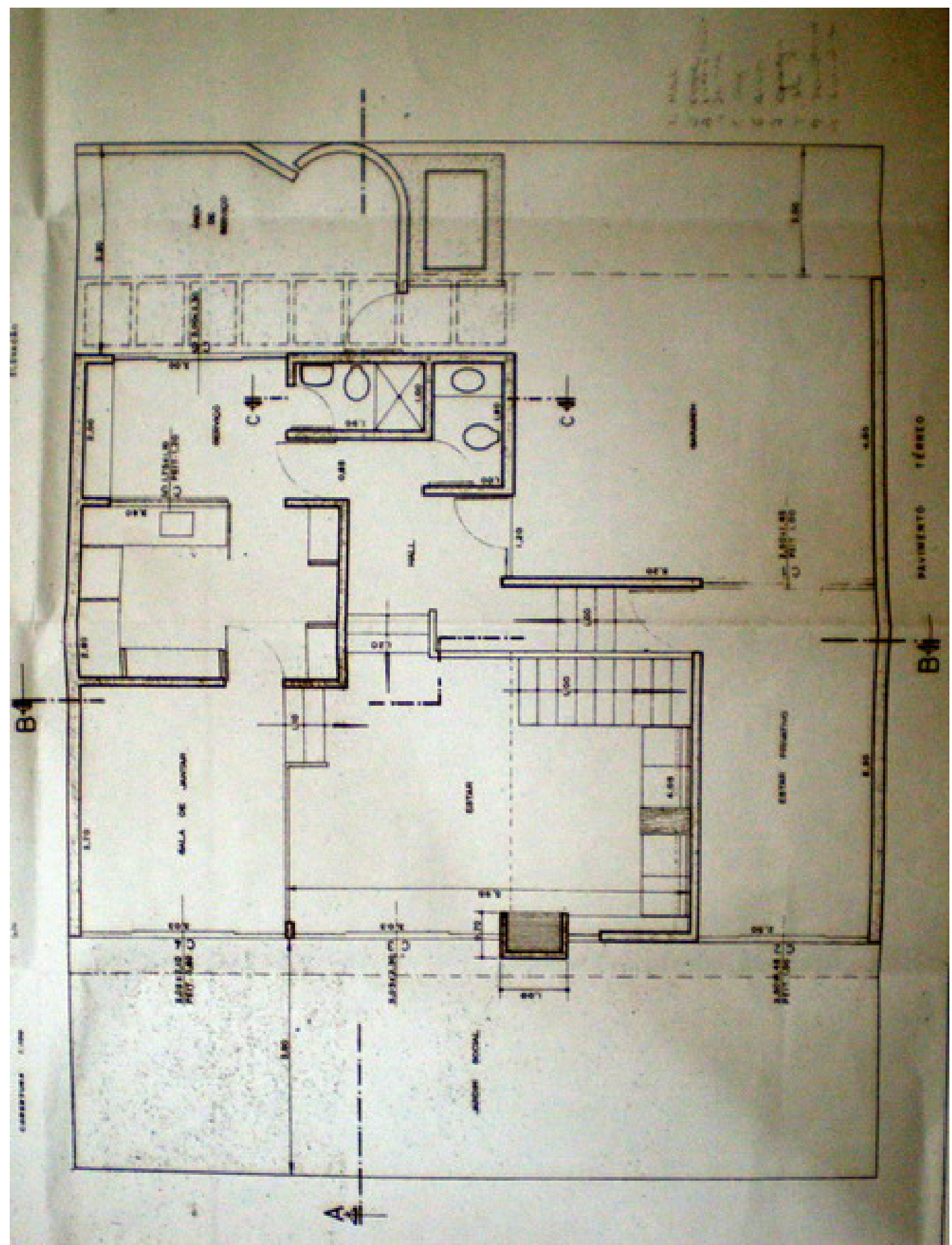

Casa Luiz Gastão de Castro Lima. Planta baixa Térreo. Fonte: Acervo pessoal da autora. 


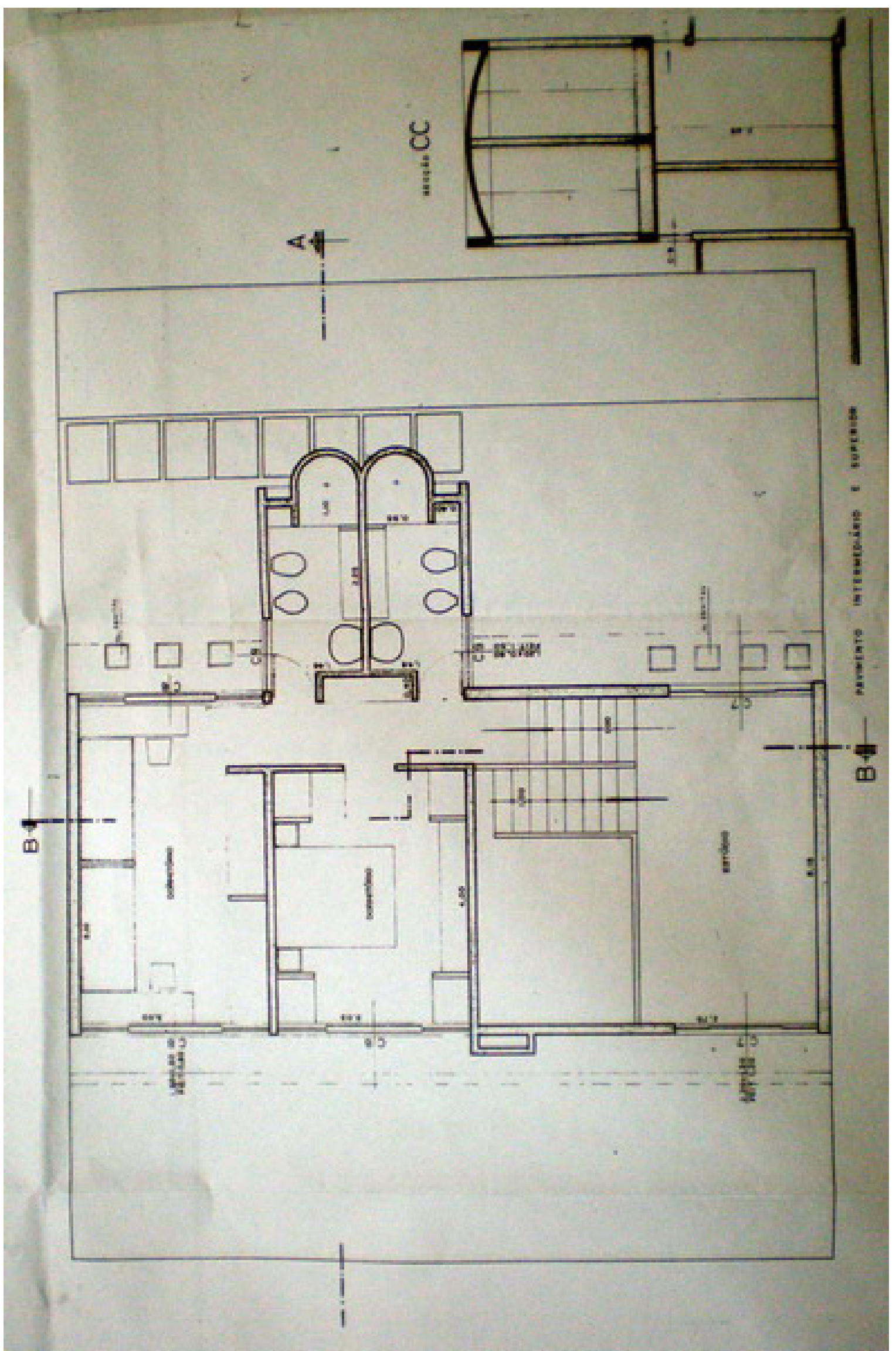

Casa Luiz Gastão de Castro Lima. Planta pavimento intermediário e superior. Fonte: Acervo pessoal da autora. 

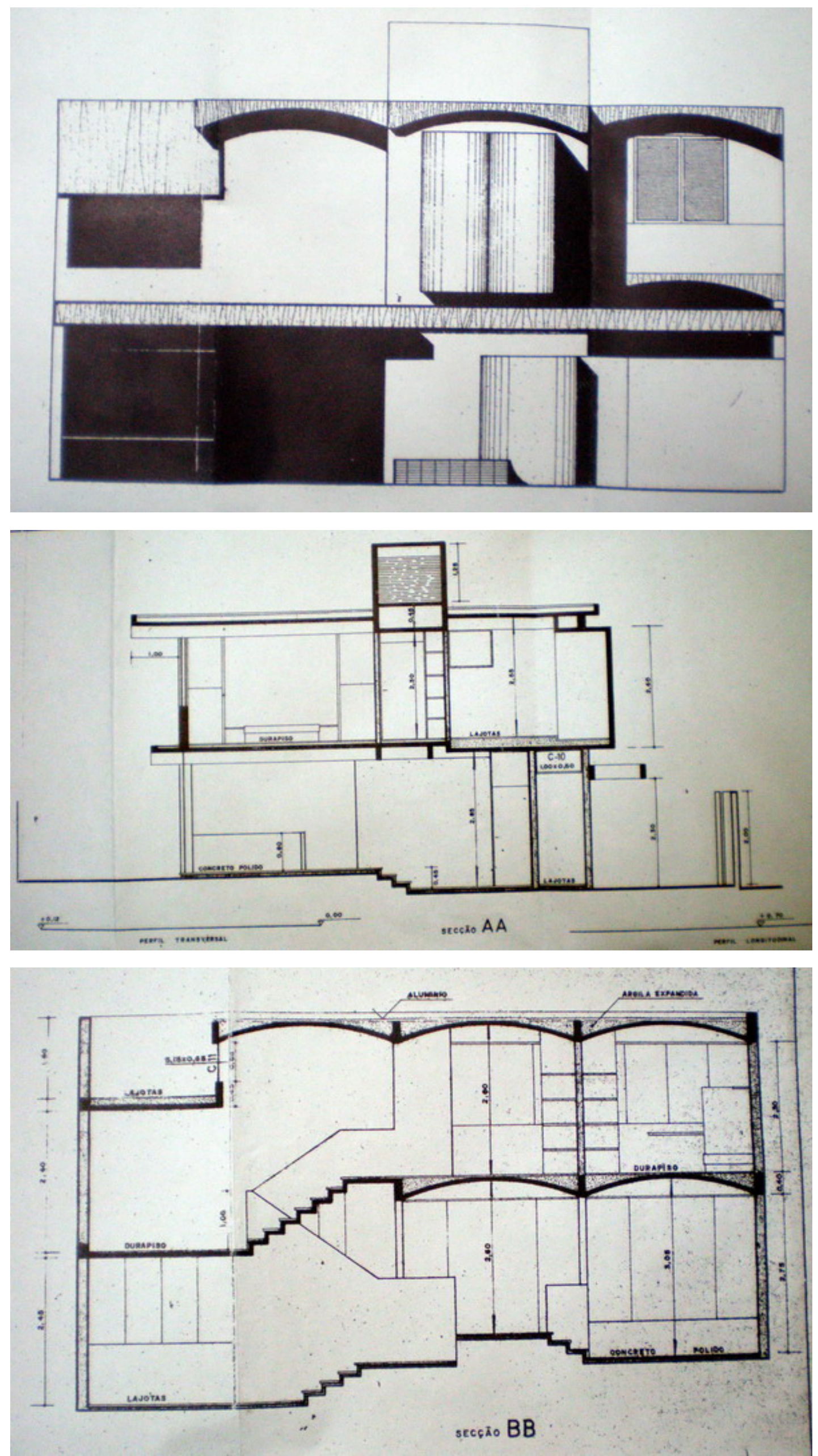

Casa Luiz Gastão de Castro Lima. Elevação frontal, Cortes AA e BB. Fonte: Acervo pessoal da autora 

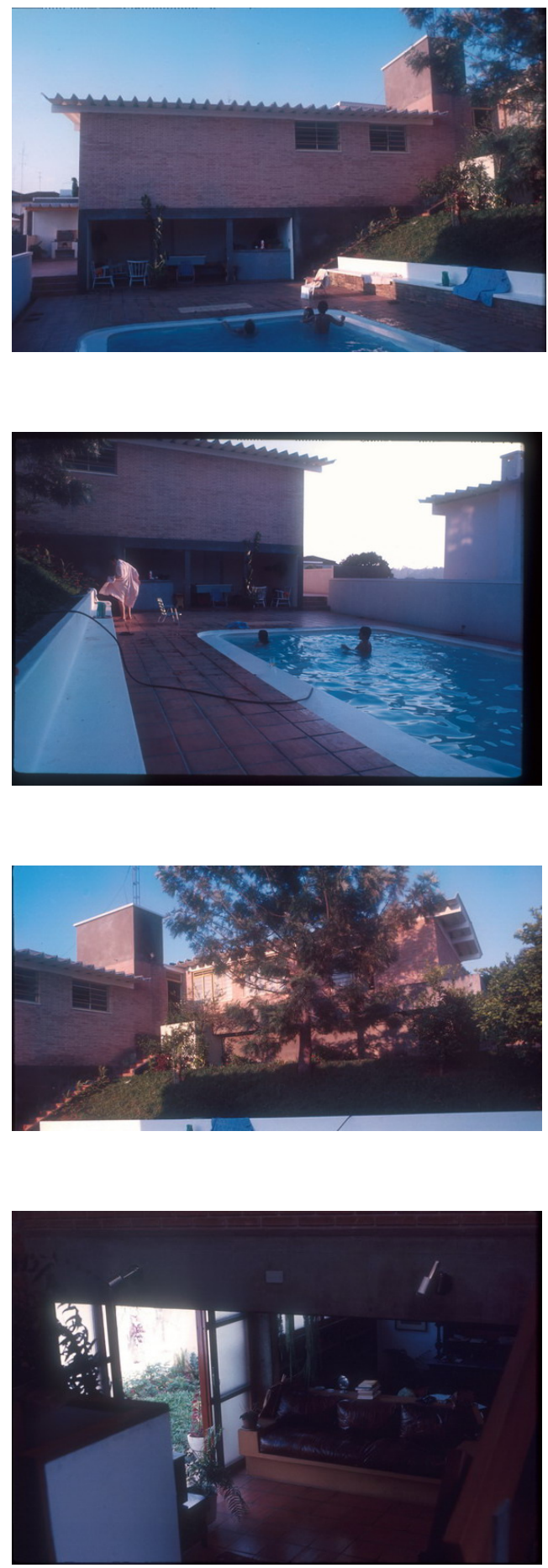

Residência em São Paulo. Próxima à Rua Cardeal Arcoverde. Acervo do arquiteto. LIEP-UFSCar

\section{Outras casas}

Ao longo da década de 70 e 80 os compromissos acadêmicos the reservaram alta carga de trabalho, ainda assim recebeu muitas encomendas de projeto, incluindo a Fábrica da Sanyo, da Wirth Latina e diversas residências.

Estas casas trazem em si elementos da arquitetura orgânica filtrados pela escola paulista, como a fluidez do espaço interno alcançado pela distribuição dos ambientes em vários níveis. Uma casa em São Paulo seria outra forte presença de Wright em seus projetos. Não localizamos 0 endereço preciso dessa construção. As fotos foram encontradas no acervo do arquiteto, que está ainda em fase de organização pelo Departamento de Engenharia de Produção da Universidade Federal de São Carlos. As informações que tivemos, através de Flávia de Castro Lima, é que se trata de um projeto elaborado pelo arquiteto para um médico em São Paulo, nas proximidades da Rua Cardeal Arcoverde.

Outros projetos manifestam igualmente elementos da arquitetura wrightiana como os generosos beirais, os pergolados e em alguns momentos, os terraços em balanço.
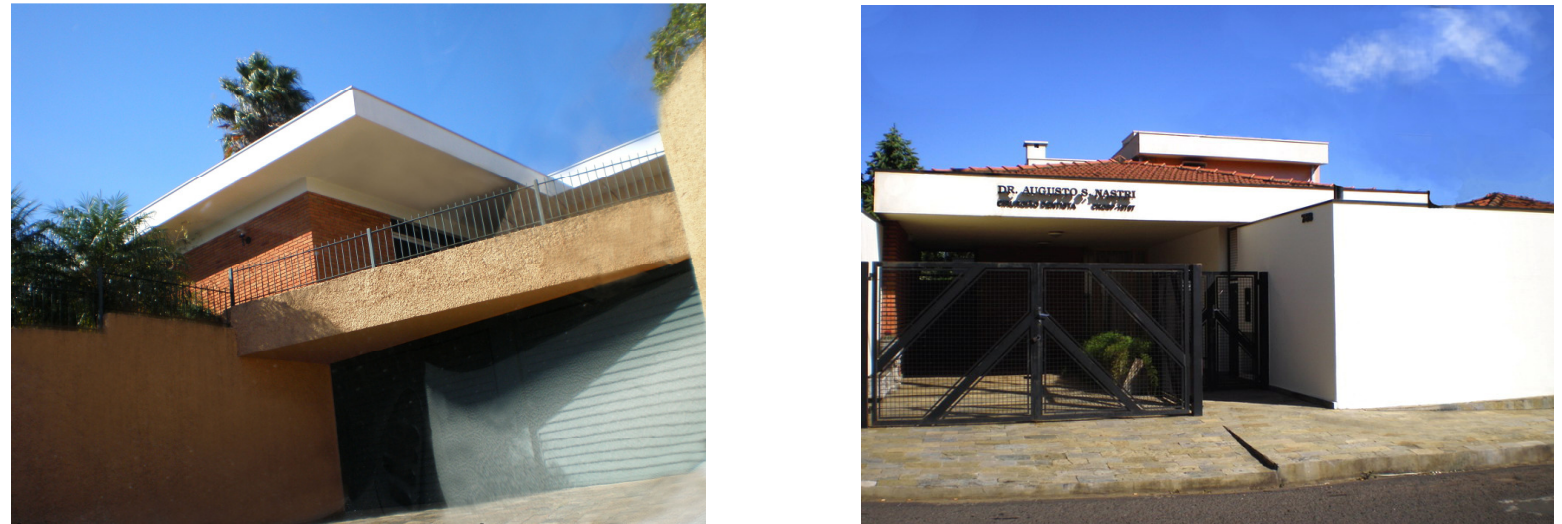

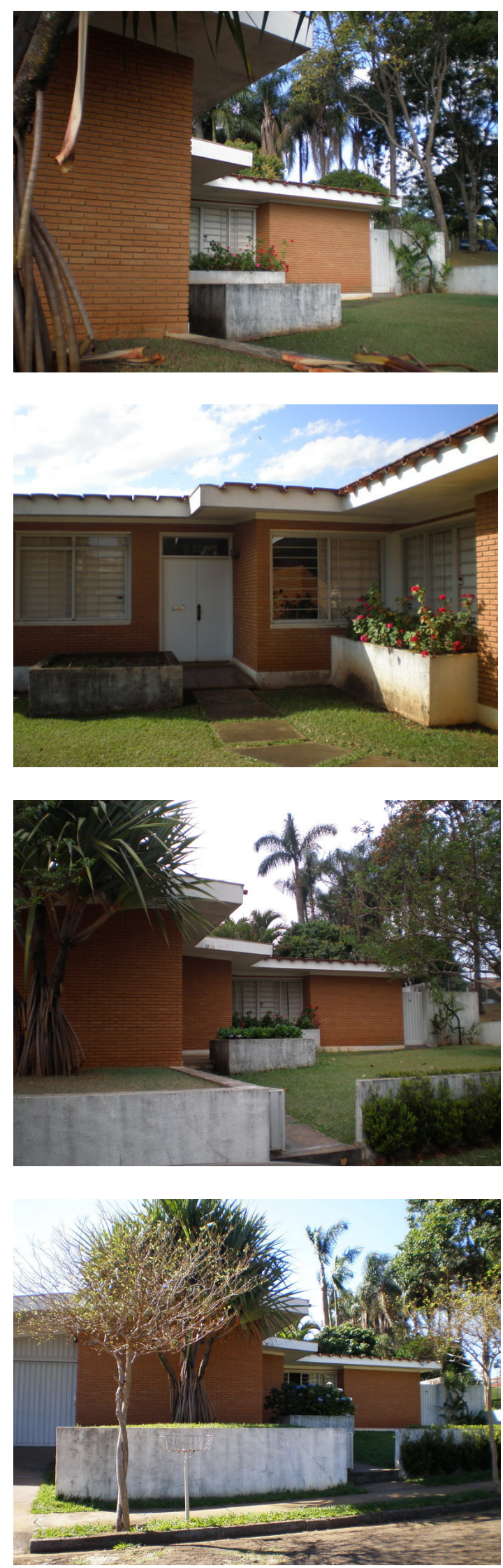

Casa Rizzoli em São Carlos. Fotos da autora
$\mathrm{Na}$ casa Álvaro e Lúcia Rizzoli em São Carlos, os beirais de águas rasas fazem uso da telha tipo taguá que favorece a baixa inclinação. Essa experiência se mostrou desfavorável com 0 tempo, pois as telhas permitiam o retorno das águas de chuva, causando infiltrações.

A casa surpreende por ainda manter as características originais, encontrando-se praticamente inalterada a sua linguagem e apresentando os revestimentos da época de sua construção.

Se abre inteiramente para uma praça lindeira e se deixa transpassar como parte do espaço público, limitado apenas pelas floreiras que vencem o desnível da rua.

Assim como a casa Senise, a casa Rizzoli adota um sistema de arandelas para a quase totalidade dos pontos de iluminação interna Mais uma vez, é setorizada em área privativa e área comum. A porta principal, ao mesmo tempo que separa, interliga. Uma vez aberta não permite ingresso direto ao interior da residência, mas dá acesso à varanda que intermedia os dois jardins (frontal e interno). A integração interior-exterior é ampliada na sala de estar através de caixilhos que ocupam todo pé-direito e se abrem às áreas verdes.

Infelizmente, durante a pesquisa não conseguimos localizar o projeto dessa residência, apesar das insistentes tentativas junto ao cadastro imobiliário e acervo histórico da Fundação Pró Memória de São Carlos. Por inúmeros motivos, não foi possível realizar um levantamento métrico no local, fato este entendido por esta pesquisa, como fundamental não apenas como documentação, mas como meio de propiciar uma melhor leitura do 
partido adotado. Acreditamos valer a pena manter o empenho e tão logo tenhamos êxito, procuraremos publicar este material em forma de artigo ou ensaio em meio de divulgação acessível.
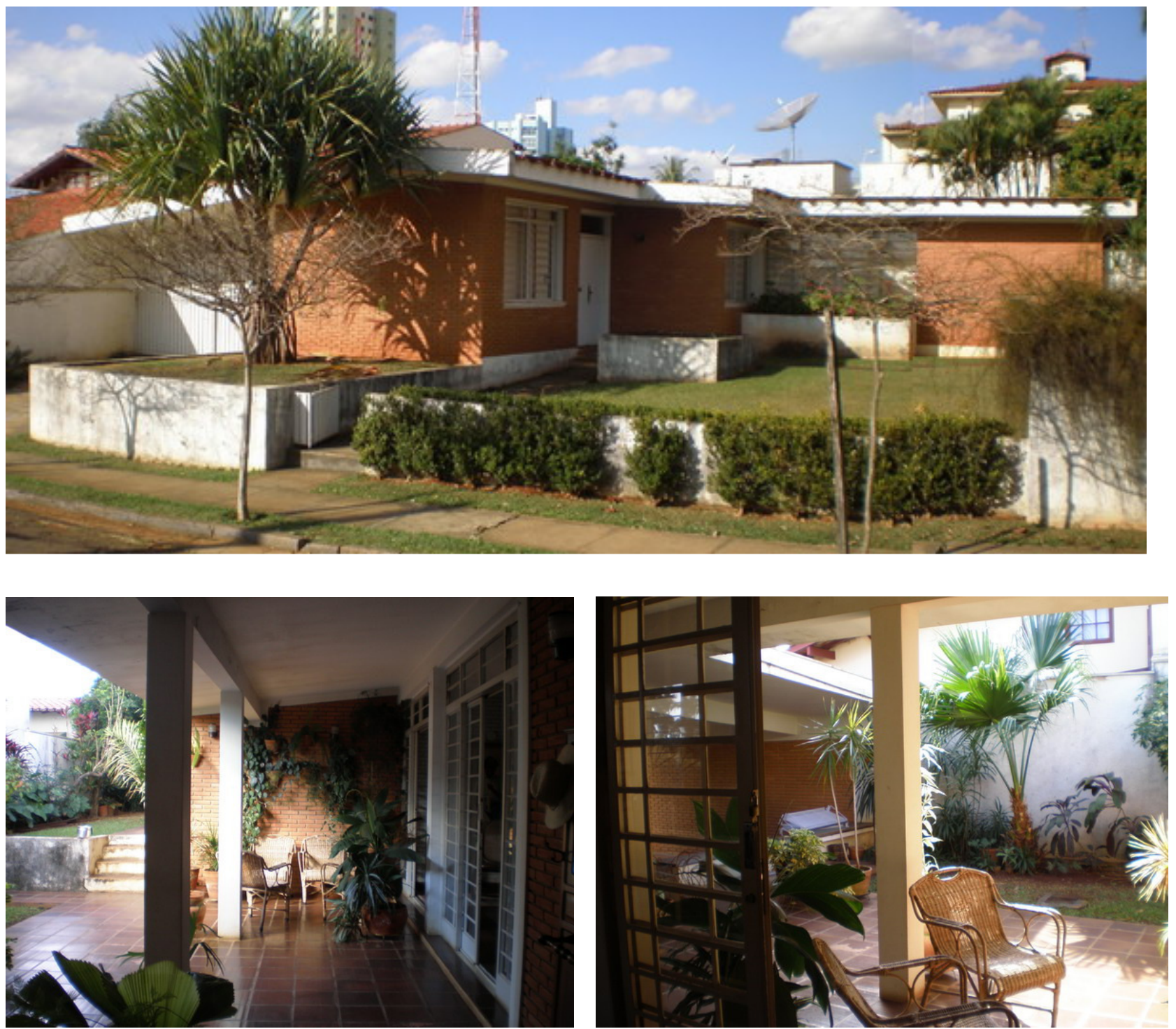

Casa Rizzoli. Acima: fachada frontal e Imagens da varanda lateral interna. Fotos da autora.
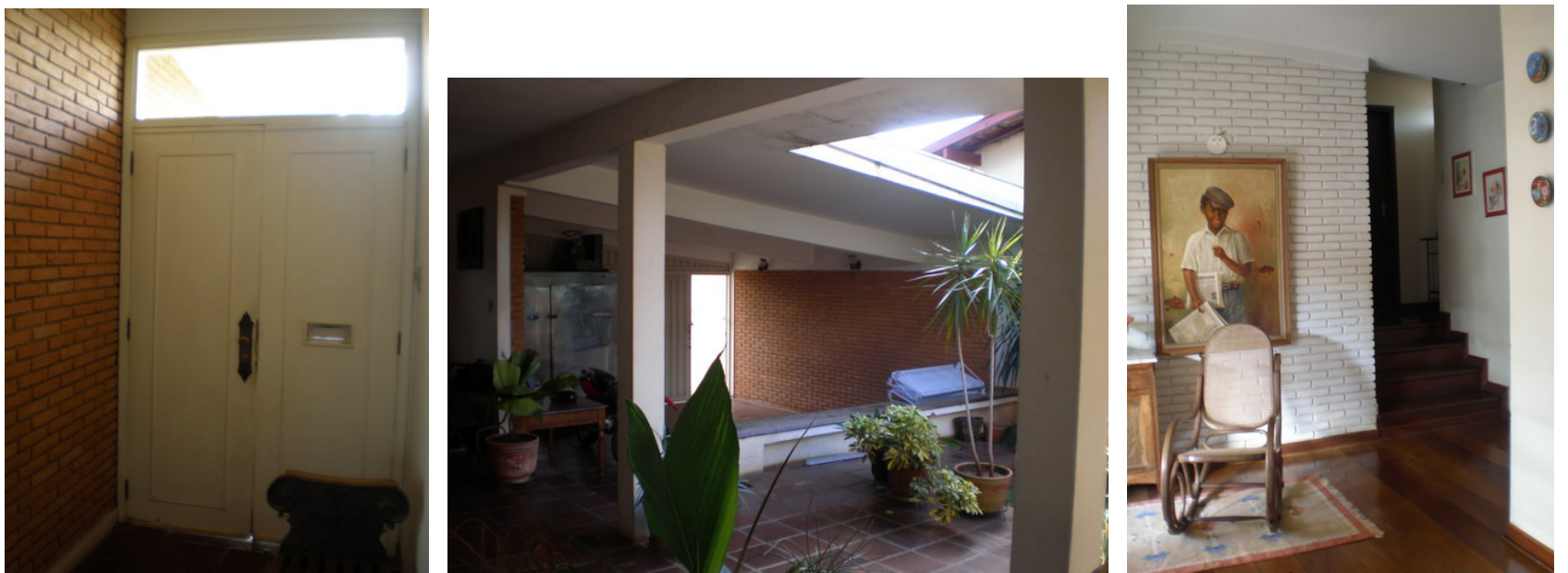

Casa Rizzoli. A esquerda: Porta de entrada vista da varanda, no centro: garagem vista da varanda. À direita: parte da sala de estar vista da varanda. Fotos da autora. 
Em muitas dessa casas, um elemento circular, geralmente associado ao muro ou a floreiras que vencem o desnível frontal nos moldes praire houses, se tornou marca registrada do arquiteto.

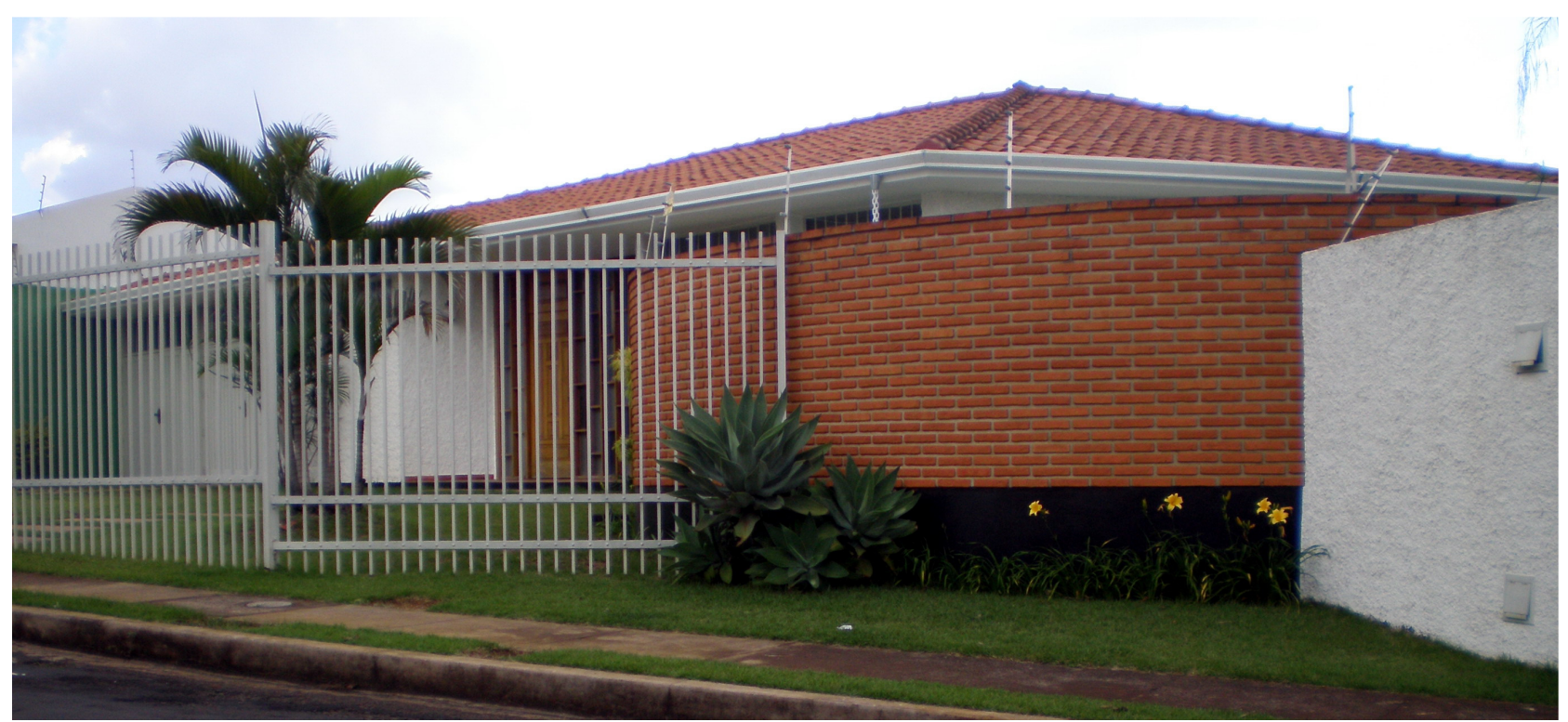

Casa da Rua Rafael de Abreu Sampaio em São Carlos. Foto da autora
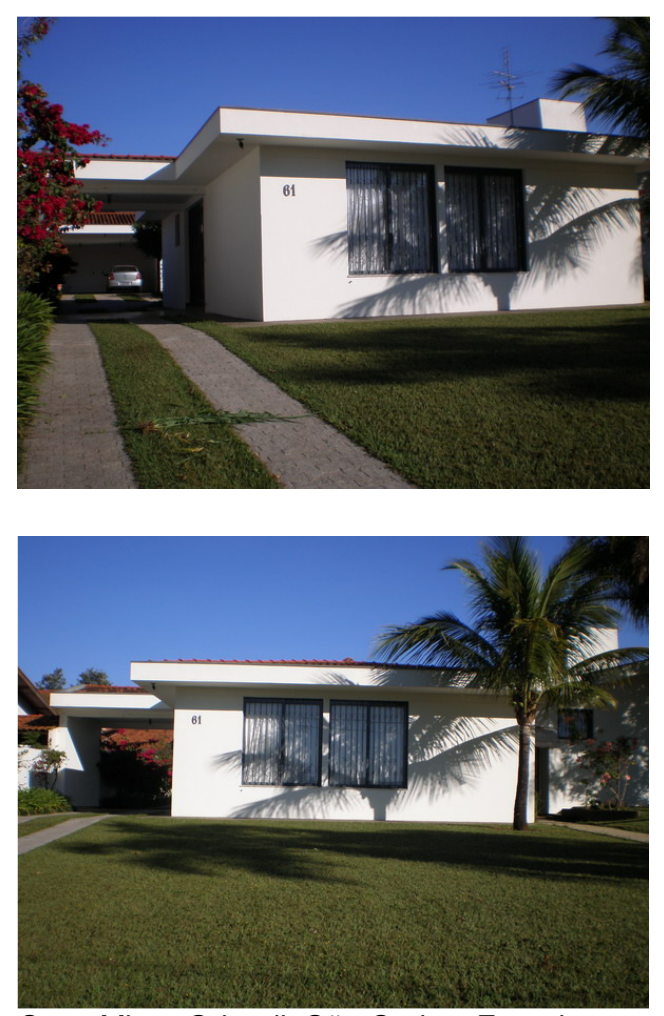

Casa Mirna Orlandi. São Carlos. Foto da autora
$\mathrm{Na}$ década de 80, dentre outras, Gastão projeta as casas Dario Rodrigues, Odney Martins e Mirna Orlandi, todas em São Carlos.

Nesta última, de 1984, a área resultante da unificação de dois terrenos de dimensões generosas está localizada em loteamento de uso estritamente residencial, no limite entre zona urbana e rural. Situada na última quadra do bairro, tem à frente uma extensa área de reflorestamento da Fábrica de Tapetes São Carlos.

A planta é composta de dois blocos interligados por uma área central de distribuição e circulação. Implantada suavemente sobre o terreno de pouca inclinação, se organiza em um único pavimento distribuído em dois níveis evitando 


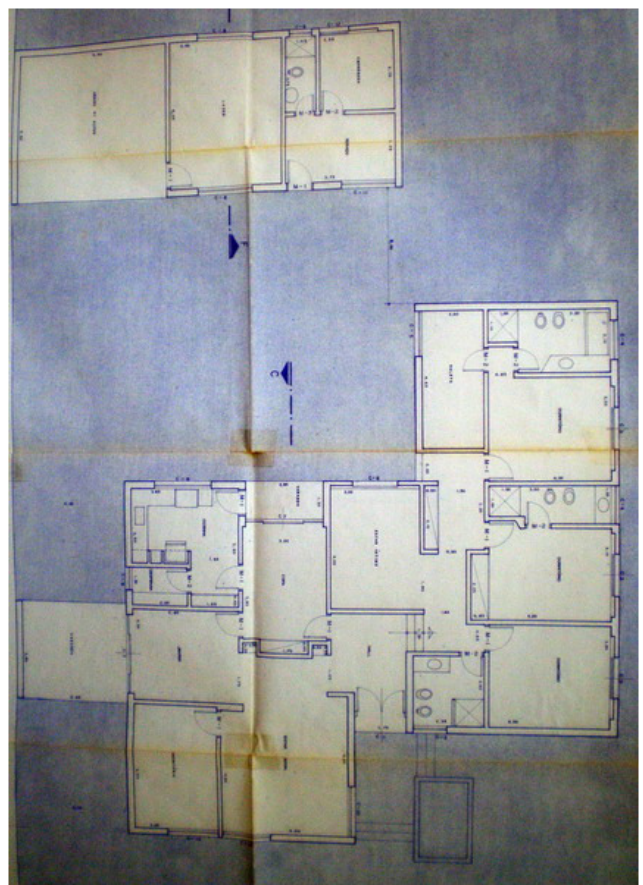

Acima: vistas externas. Abaixo: Planta baixa. Casa Mirna Orlandi. Fotos da autora. Desenhos fornecidos por Mirna Orlandi cortes ou aterros, ainda que oriundos de pequenas movimentações de terra. A inclinação da cobertura é suave, levada ao mínimo possível para um telhado com telhas de barro.

A casa tem as áreas íntima, social e de serviços organizadas em duas zonas: diurna e noturna, em aproximação às concepções binucleares de Marcel Breuer.

Esta obra revela passagens interessantes no enfrentamento da realidade de projeto colocada pelo programa. A proprietária revela:

Eu queria muito uma edícula, com a garagem no fundo do lote, com um dormitório e banheiro de serviços. O Gastão fez de tudo para me fazer desistir dessa idéia. Me deu uma aula de história da arquitetura, explicando que isso não se usava mais, que eram resquícios da época das cocheiras, mas eu quis que fosse assim.

Essa declaração revela a imagem do professor presente no arquiteto e mostra uma postura na tentativa de materializar uma tipologia que poderia ser melhor aceita na capital, mas que ainda encontrava resistência no contexto interiorano.

Contrariando os princípios wrightianos, Gastão dissolveu a concepção do workspace e da linha hidráulica e se viu na tarefa de retomar hábitos ou vícios da tradição que tanto evitou nos projetos anteriores. 

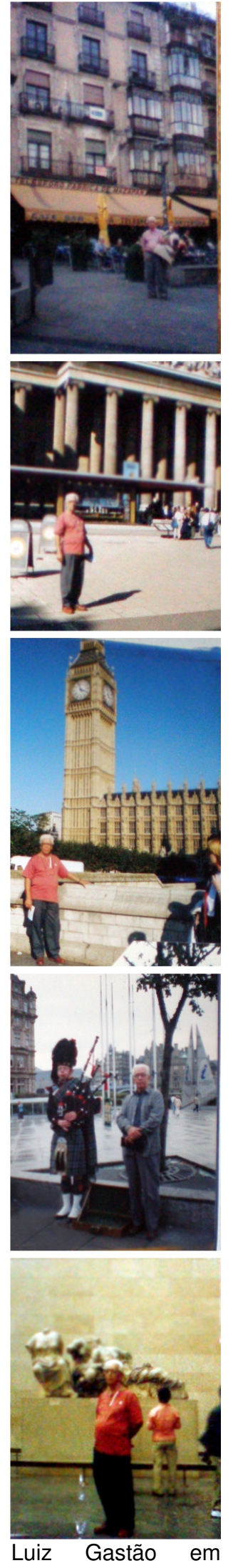

viagens à Europa.

Fonte:

acervo particular do arquiteto

\section{As viagens de estudo}

Gastão se dividia a esta altura entre os projetos de arquitetura e os compromissos acadêmicos.

Durante os traslados entre uma e outra instituição de ensino, orientando diversos alunos de graduação e pós-graduação, desenvolve trabalhos junto à Universidade Federal do Pará (UFPA) e ministra cursos na Universidade Estadual de Londrina e Universidade Federal de Alagoas. Em meio a todos os compromissos docentes, inicia um movimento a fim de trazer o IAB (Instituto de Arquitetos do Brasil) para o interior, enquanto é eleito presidente da AEASC - Associação dos Engenheiros, Arquitetos e Agrônomos de São Carlos, único arquiteto até hoje a ocupar o cargo.

Em 1986 o arquiteto apresenta um projeto de pós $\mathrm{DOC}$ e recebe em novembro, um comunicado da Fapesp sobre o deferimento de sua bolsa. Após 32 anos como docente, se aposenta e embarca para a Europa onde, durante dois anos, desenvolve programa de aperfeiçoamento científico. Passa parte do tempo trabalhando junto à Escola de Arquitetura de Grenoble e ao Instituto de Ciencias de la Construcción Eduardo Torroja, em Madri, onde tem a oportunidade de conhecer e trabalhar com Julian Sallas Serrano. Serrano vinha desenvolvendo pesquisas sobre soluções tecnológicas para habitações populares. Nesta ocasião, se tornariam grandes amigos. 
As experiências vividas no Instituto Torroja formaram a base conceitual da proposta de implantação de cursos de pós-graduação que Gastão pretendia desenvolver na UNESP em Bauru, onde atuava como docente desde o início dos anos 70. Estas propostas foram expostas por ele, na XIII Conferencia Latinoamericana de Escuelas y Facultades de Arquitectura, realizado na Universidade de San Carlo, na Guatemala em 1989, onde Gastão relata as experiências colhidas durante a estadia na Europa.

Durante el período de estância em el Instituto Eduardo Torroja, tuvimos la oportunidad de consultar uma extensa bibliografia relacionada com la arquitectura y la tecnologia de las construcciones, e incluso actualizar nuestros conocimientos relativos al "Estado del Arte" internacional sobre el tema de los asentamientos humanos y la vivienda de bajo coste. ${ }^{4}$

$\mathrm{Na}$ conferência, Gastão apresenta a estruturação de um curso de pós-graduação sólido e multidisciplinar, porém flexível de forma a se moldar de acordo com as necessidades, a partir de análises de desempenho.

Las líneas de investigación, desarrolladas a partir de esta etapa del curso, deben consolidarse em armonia com la experiência que se vaya acumulando, de manera que se transformen posteriormente, de acuerdo com el rendimento

\footnotetext{
${ }^{4}$ Luiz Gastão de Castro Lima: A problemática habitacional latinoamericana. In Catálogo XIII CLEFA. Conferencia Latinoamericana de Escuelas y Facultades de Arquitectura. San Carlo, Guatemala, 1989.
} 
constatado, em las líneas pretendidas por los objetivos y sus posibles énfasis.

Gastão tinha plena consciência da necessidade de criação de um curso livre e dinâmico, que buscasse alcançar o equilíbrio entre a teoria e a prática. Sendo assim, enfatizava a problemática urbana, o desenho e a construção com seus distintos matizes.

Sugeria como complemento indispensável, alguns tópicos pertinentes à industrialização das construções e habitação de interesse social e reunia a metodologia de enfoque tecnológico da Escola de Engenharia de São Carlos e sua aplicabilidade nas experiências vividas no Instituto espanhol.

Para o arquiteto que toma a si a responsabilidade de uma resposta, não basta apenas a solução dos problemas no plano profissional de seu escritório. A colocação desses problemas no campo do ensino, livre das limitações da prática profissional, é forma decisiva de contribuição. ${ }^{5}$

\footnotetext{
${ }^{5}$ Trecho do relatório Seqüência de desenho industrial, publicado in UNIVERSIDADE DE SÃO PAULO. Faculdade de Arquitetura e Urbanismo. Departamento de Projeto. Desenho Industrial 1962. Publicação 8. 1963. Estes relatórios representam as atividades desenvolvidas na FAU a partir da reforma curricular de 1962 e da introdução das disciplinas de D.I. e C.V. É parte desse encarte, os relatórios de Hélio Duarte, Marlene Picarelli e Lúcio Grinover (primeiro ano), Ernest Mange, João Baptista Alves Xavier e Cândido Malta Campos Filho (segundo ano), José Maria da Silva Neves, Abrahão Sanovicz e Luiz Gastão de Castro Lima (terceiro ano) e Roberto Cerqueira César, Luis Roberto Carvalho Franco e Dario Imparato (quarto ano).
} 


\section{Postura profissional}

Luiz Gastão de Castro Lima manteve o olhar sempre atento à produção de sua época e buscou encontrar em sua própria obra, um ponto de inflexão com a arquitetura que julgava digna de atenção, não se detendo exclusivamente ao eixo Rio-São Paulo. Em 1979 já chamava a atenção para uma obra no sul do Brasil, que só mereceria maiores créditos por parte da historiografia vinte anos depois.

$\mathrm{Na}$ minha opinião, um dos melhores projetos que vi produzidos no Brasil nos últimos anos foi o Ceasa de Porto Alegre. (...) O Ceasa de Porto Alegre foi projetado pelos grandes escritórios de Porto Alegre, de Cláudio Araújo, Obino e Fayet e teve uma assessoria de cálculo de um uruguaio chamado Eladio, com grande tradição no uso da alvenaria armada. Para vocês terem um idéia, o Ceasa de Porto Alegre tem vão de $35 \mathrm{~m}$ executado com tijolos armados em forma de casca, com a utilização da assessoria desse uruguaio, com sistema de protensão que não pagou royalties. Ele inventou um sistema de protender o aço, aço 50 comum, não é aço especial. ${ }^{6}$

Datado do início dos anos 70, o Ceasa de Porto Alegre, projeto que expressa arrojo estrutural

\footnotetext{
${ }^{6}$ Luiz Gastão de Castro Lima em depoimento In INSTITUTO DOS ARQUITETOS DO BRASIL São Paulo. Arquitetura e desenvolvimento nacional: depoimentos de arquitetos paulistas. Pini, São Paulo, 1979. O uruguaio Eládio a que Gastão se refere é Eladio Dieste, personagem ainda pouco estudado no Brasil. Dieste foi um dos mais brilhantes e criativos projetistas estruturais, com obras significativas em várias partes do país. Ver: COMAS, Carlos Eduardo; CANEZ, Anna Paula; BOHRER, Glênio Vianna. Arquiteturas Cisplatinas: Roman Fresnedo Siri e Eladio Dieste em Porto Alegre. Porto Alegre, UniRitter, 2004.
} 
traduzido numa solução simples, ficou mais conhecido depois da publicação em 2000 do livro Arquiteturas Cisplatinas, fruto do trabalho e pesquisa de Carlos Eduardo Comas, Glênio Boher e Anna Paula Canez.

O arquiteto destacava no contexto internacional a arquitetura catalã. Dizia sobre certa ignorância nossa sobre os arquitetos espanhóis uma vez que estávamos "implantados no modernismo como um paradigma" de forma que grande parte da arquitetura produzida era "arquitetura de moda, arquitetura de grife." Sobre o Ceasa, dizia ainda:

Está lá o testemunho do que é possível fazer com uma técnica arrojada, com materiais altamente convencionais. Realmente uma tecnologia que a gente poderia chamar de cabocla. ${ }^{7}$

Gastão chama a atenção para a realização do projeto absorvendo o potencial da arquitetura local, idéia defendida em toda sua vida. Essa visão de que os projetos deviam ser realizados pelos arquitetos da região foi uma das razões que o motivou a montar um dos primeiros núcleos do IAB no interior.

Ele [Gastão] queria montar o IAB exatamente por causa disso, porque ele tinha a visão de que as obras da região deviam ser feitas pelos arquitetos da região. Não por uma questão de mercado, mas 
por uma questão que a gente sempre reconheceu que é: aquele que está mais próximo do território é que é capaz de interpretar o território. Um arquiteto de São Paulo vai trazer a visão paulistana para resolver um problema local. Primeiro é irresponsável do ponto de vista de não ficar mais no lugar, ele faz e vai embora. Se você faz no seu lugar você continua a responder pelo resto da vida por aquilo que você fez. ${ }^{8}$

Uma primeira tentativa de reunir os arquitetos e constituir um núcleo do IAB na cidade teria sido feita por Luiz Gastão na década de 70, mas o núcleo de São Carlos só se consolidaria vinte e oito anos depois.

Gastão revela em sua trajetória a síntese de sua busca profissional, na convivência harmoniosa das possibilidades da tecnologia apoiadas na técnica simples e nos materiais disponíveis.

Como já demonstrado, seu compromisso como docente rendeu uma dedicação de anos de estudo no desenvolvimento e aprimoramento de uma metodologia de ensino do desenho. Seu interesse sobre o tema nas escolas de Engenharia advinha de uma postura como arquiteto, ciente da linha tênue que divide as duas profissões. Dizia ele:

"Embora os cursos de arquitetura e de engenharia tenham objetivos próprios, não há dispositivo legal que delimite as atribuições dos profissionais, o que

${ }^{7}$ Luiz Gastão de Castro Lima em depoimento In INSTITUTO DOS ARQUITETOS DO BRASIL - São Paulo. Arquitetura e desenvolvimento nacional: depoimentos de arquitetos paulistas. Pini, São Paulo, 1979.

${ }^{8}$ Araquém Martinho em depoimento à autora. 
torna os dois cursos irmãos quanto à diplomação, embora somente aparentados quanto aos currículos."

llustrado na página seguinte, o esquema clássico de Le Corbusier buscava demonstrar que ambas se complementavam "cabendo ao engenheiro maior soma de especialização e dedicação nas atividades eminentemente técnicas da construção, e ao arquiteto maiores interesses e afinidades com as áreas ligadas às chamadas ciências humanas".

Esse esquema ilustra a contracapa da tese de doutorado do arquiteto e denota uma profunda preocupação com o ensino e a profissionalização, sob o aspecto da má formação resultante de cursos de engenharia mal estruturados e sob o aspecto do distanciamento da ciência e da tecnologia por parte dos alunos de arquitetura.

Estes, segundo ele, caminhavam para uma "artistificação", pretendendo colocar a arquitetura em um "discutível pedestal de arte plástica para iniciados". 


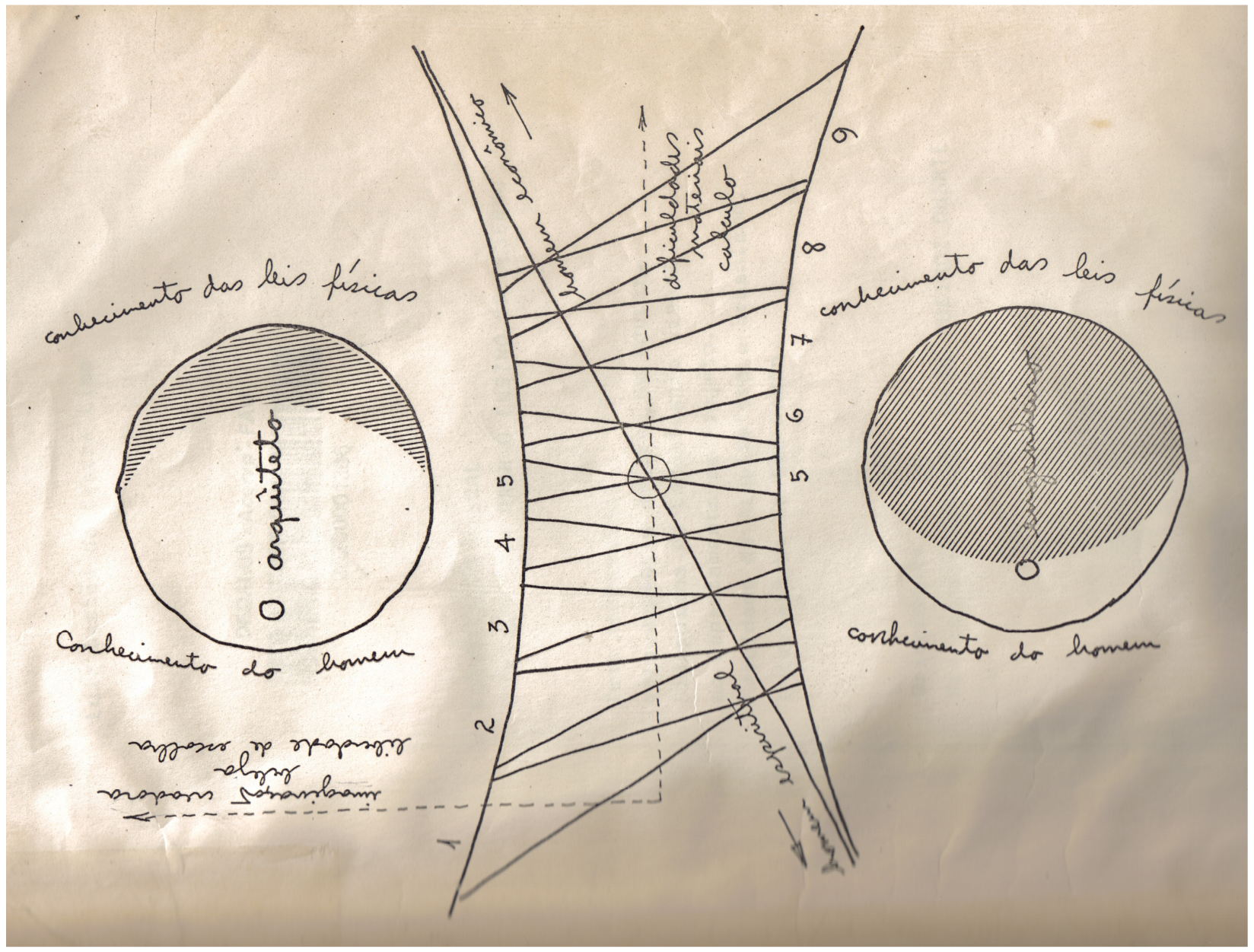


CONSIDERAÇÕES FINAIS

qualquer tolo, COM UM MINIMO de INTELIGENCIA, PODE CRIAR COISAS MAIORES E MAIS COMPLEXAS. MAS É PRECISO UM TOQUE DE GENIALIDADE - E MUITA CORAGEM - PARA CAMINHAR EM DIREÇÃO À SIMPLICIDADE. 


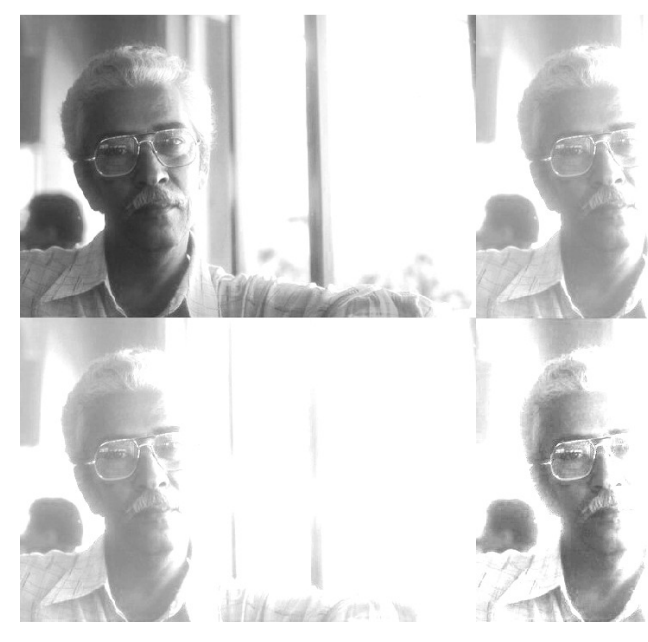

Em dezembro de 2003 se encerra a carreira de Luiz Gastão de Castro Lima, após uma vida inteira dedicada à arquitetura e ao ensino.

Esta pesquisa se propôs a apresentar e iniciar uma reflexão sobre sua obra, percorrendo os campos mais diversos pelos quais caminhou. Como primeiro estudo sobre a trajetória do arquiteto, assumiu desde o início certo cunho biográfico e buscou apresentar o perfil de um profissional dentro de sua área de atuação, em todos os segmentos.

Mostramos aqui os caminhos trilhados pelo arquiteto, pautados sempre na coerência ao seu tempo e lugar, revelando uma atuação consciente da dimensão cultural e tecnológica que se apresentava em cada projeto.

Durante sua vida, Luiz Gastão de Castro Lima viajou por diversos campos, estendendo a investigação com visão científica, além dos limites projetuais. Esse caráter técnico jamais o distanciou dos aspectos mais subjetivos que caracterizaram seu perfil de artista. Gastão se entregou aos apelos da música, das artes e curiosamente da culináriasegundo os amigos, um de seus maiores talentosdotado como sempre foi de uma capacidade enorme de dispersão de habilidades.

A análise dos projetos revelou um grande domínio técnico -Gastão costumava calcular suas 
obras- aliado a uma sensibilidade nem sempre perceptível aos olhos comuns. Muitos detalhes traduzidos em simples soluções construtivas só seriam revelados com uma observação minuciosa.

Luiz Gastão foi um arquiteto de laboratório. Sua preocupação esteve além do aspecto plástico. Denotava um profundo conhecimento e atenção na assimilação de conceitos de conforto ambiental, na viabilidade financeira, na proporção do passo. 0 cálculo preciso é presente em cada detalhe e revelado a partir do uso do espaço, desde o dimensionamento correto dos percursos que ritma um passo confortável até o escoamento das águas pluviais, no caimento correto e imperceptível dos planos horizontais ao nível do solo. Nesse sentido, a simplicidade de suas fachadas muitas vezes não revelou a riqueza das soluções internas.

Nos projetos institucionais, embora tenha trabalhado com edifícios isolados, conferiu identidade ao conjunto e determinou uma linguagem que foi adotada como "modelo" e reproduzida nos edifícios seguintes, de autorias diversas.

O valor de sua arquitetura está presente no conjunto, não apenas materializado em forma de construção, mas na semente deixada nas instituições de ensino por onde passou.

Discreto, modesto, simples, se manteve distante de grandes polêmicas e agitações. Unânimes em seus depoimentos, amigos e colegas de trabalho destacaram com veemência sua visão humanista e desenharam o perfil de um profissional 
competente, de grande cultura, de extrema generosidade e desapego material.

Uma grande admiração pela obra de Frank Lloyd Wright, que nascera ainda durante a graduação, o acompanhou a vida inteira e se materializou em uma obra pautada nos princípios humanistas de fundamento orgânico.

A honestidade de sua arquitetura, ainda que permeada de influências, referências e inspirações diversas, teve a marca de seu próprio traço e não se rendeu à hegemonia de uma época. Esboçados nos limites dessa mesma época, modulados por orçamentos enxutos, na sua grande maioria executados no âmbito privado, seus projetos manifestaram mais que uma releitura atenta de Wright, uma concepção que se debruçou sobre o projeto com demasiado apuro técnico.

Seu trabalho pioneiro foi sendo desvelado não somente a partir da análise dos projetos e dos depoimentos colhidos, mas de suas próprias palavras.

Não seria possível eu criar um nível de detalhamento em desenho muito alto porque percebi que estava desenhando pra mim, porque o pessoal que executava a obra não tinha a formação sofisticada do profissional de São Paulo ou de grandes firmas. Eu tive profissionais excelentes, incríveis pedreiros, absolutamente analfabetos. E que não sabiam em que escala estava a planta, simplesmente. Mas executavam fantasticamente bem, alvenaria, revestimento, mão de obra finíssima. ${ }^{1}$

\footnotetext{
${ }^{1}$ Luiz Gastão de Castro Lima em INSTITUTO DOS ARQUITETOS DO BRASIL - São Paulo. Arquitetura e desenvolvimento nacional: depoimentos de arquitetos paulistas. Pini, São Paulo, 1979.
} 
(...) Nos idos de 60, quando me formei, existiam em São Paulo somente dois cursos de Arquitetura (...)O número de profissionais era escasso.

(...) $\mathrm{O}$ interior não conhecia muito bem qual seria a real função do arquiteto, que começava a aparecer em diversas cidades. Confundia-se o mesmo com o decorador, uma espécie de simples rabiscador de bonitas fachadas.

Aos poucos, esses que optaram por uma qualidade de vida com menos atribulações, porém menos oportunidades e vantagens (principalmente de ordem cultural) em relação ao que se passava no grande centro urbano, começaram a desempenhar um crescente papel nas comunidades, mostrando quais eram nossas reais qualificações. $^{2}$

Sua trajetória, ainda que pautada na experiência individual, é capaz de lançar luz sobre a história da arquitetura moderna brasileira e sua difusão no interior do estado de São Paulo.

O descortinar da figura do arquiteto numa cidade de forte tradição na engenharia, a abertura de caminhos para o profissional de arquitetura na materialização de uma obra consciente e coerente talvez tenha sido seu maior legado.

Entre protagonistas, personagens esquecidos ou desconhecidos, a história se constrói. Se Luiz Gastão de Castro Lima foi protagonista ou coadjuvante, a resposta estará sujeita à relatividade do enfoque.

\footnotetext{
${ }^{2}$ Luiz Gastão de Castro Lima em depoimento durante a abertura do 3ํㅡㄹ Congresso Estadual de Arquitetos em São Carlos, em março de 2003. Fonte: Boletim IAB № 34 . março/03.
} 
"hOJE não faço maIs nada, mas se fosse fazer uMa casa, eu FARIA UMA CASA WRIGHTIANA."

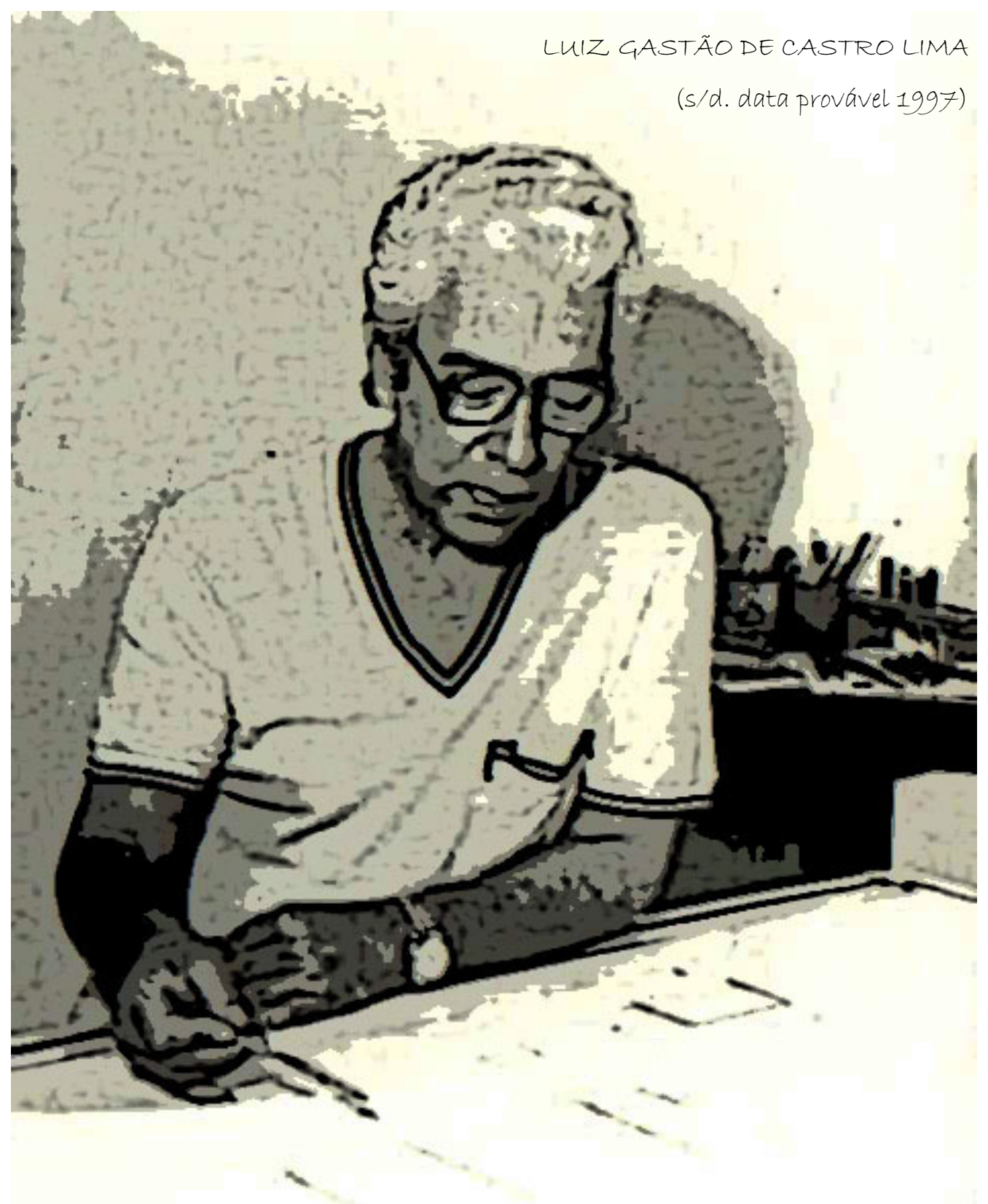


REFERÊNCIAS 
ACAYABA, M.M. Branco e preto uma história de design brasileiro nos anos 50. São Paulo: Instituto Lina Bo e P.M. Bardi, 1994.

. Residências em São Paulo, 1947-1975. São Paulo: Grupo EUCATEX, 1986.

ALTAFIM, R.A.C.; SILVA, M.A.A. 50 anos da EESC: um olhar no passado visando ao futuro. São Carlos: EESC, 2004.

ANDRADE, M. Cartas de Mário de Andrade a Luis da Câmara Cascudo. Itatiaia, 2000.

ANELLI, R.; GUERRA, A.; KON, N. Rino Levi: arquitetura e cidade. São Paulo: Romano Guerra, 2001.

ARANTES, O.; FAVARETTO, C.; SUZUKI JUNIOR, M. Arte em revista: anos 60, ano 1, n.1. São Paulo: Kairós, 1979.

ARANTES, P.F. Arquitetura nova Sérgio Ferro, Flávio Império e Rodrigo Lefèvre, de Artigas aos mutirões. São Paulo: [s.n.], 2000.

ARGAN, G.C. Projeto e destino. São Paulo: Ática, 2000. (Coleção Arquitetura e Design, 71).

Arte moderna - do iluminismo aos movimentos contemporâneos. São Paulo: Cia das Letras, 1993.

ARTIGAS, J.B.V. Vilanova Artigas: arquitetos brasileiros. São Paulo: Instituto Lina Bo e P.M. Bardi; Fundação Vilanova Artigas, 1997.

1986.

Caminhos da arquitetura. 2.ed. São Paulo: Fundação Vilanova Artigas,

ASSOCIAÇÃO BRASILEIRA DE ÁGUAS SUBTERRÂNEAS. Homenagem a Roch Lionel Lavoie. Disponível

em:<http://www.abas.org/index.php?PG=abas news\&DET ABN=00068>. Acesso em: 04/10/2007

BANHAM, R. El Brutalismo em arquitectura: etica ou estética?. Barcelona: Gustavo Gili, 1967.

BARONE, A.C.C. Team 10, arquitetura como crítica. São Paulo: Annablume, 2002.

BEHRENDT, C.W. Arquitectura moderna: su naturaleza, sus problemas y formas. Buenos Aires: Infinito, 1959.

BITTENCOURT, D.M.M.; SILVA, E. Análise comparativa entre as principais correntes do movimento modernista na arquitetura: o racionalismo funcionalista e o organicismo; os movimentos efêmeros: expressionismo, futurismo e construtivismo; consolidação de um "estatuto" da arquitetura modernista: constantes e variáveis dos códigos modernistas. Porto Alegre: Universidade Federal do Rio Grande do Sul, 1999. Apostila de aula. 
BLAKE, P. Maestros de la arquitectura: Le Corbusier, Mies van Der Rohe, Frank Lloyd Wright. New York: Knopf, 1961.

Frank Lloyd Wright e o domínio do espaço. Rio de Janeiro: Record, 1966.

BO BARDI, L. Tempos de grossura: o design no impasse. São Paulo: Instituto Lina Bo e P.M.Bardi. 1994.

BONDUKI, N. Origens da habitação social no Brasil. São Paulo: Estação Liberdade; FAPESP, 1998.

BONDUKI, N.G. A Poética da economia: o pensamento e a obra de três importantes arquitetos brasileiros dos anos 70 . Resenha publicada originalmente no Jornal Folha de São Paulo, em 14 de fevereiro de 2004.

Affonso Eduardo Reidy: arquitetos brasileiros. São Paulo: Instituto Lina Bo e P.M. Bardi, 2000.

BRASIL em síntese. 2008. Disponível em:<www.ibge.gov.br/brasil em sintese $>$. Acesso em: 03/05/2008

BRUAND, Y. Arquitetura contemporânea no Brasil. São Paulo: Perspectiva, 1981.

BRUDER, C. Forças e esforços: a criação do departamento de jornalismo na ECAUSP. Disponível

em:<http://www.marquesdemelo.pro.br/referencias/midiaticas/ref mid 04.htm>.

Acesso em: 20/02/2008

BUZZAR, M.A. João Batista Vilanova Artigas - elementos para a compreensão de um caminho da arquitetura brasileira - 1938-1967. 1996. 337p. Dissertação (Mestrado) Faculdade de Arquitetura e Urbanismo, Universidade de São Paulo, São Paulo, 1996.

Lúcio Costa, a ENBA e a arquitetura moderna brasileira. In: SEMINÁRIO ESCOLA DE BELAS ARTES 180 anos, 1996, Rio de Janeiro. Anais... Rio de Janeiro: EBA, 1996. p.397-405.

CAMARGO, A.R. Notas sobre a história do departamento de arquitetura e urbanismo da Escola de Engenharia de São Carlos da Universidade de São Paulo. [S.I.:s.n.], [200-?]. Texto cedido pelo Prof. Eduvaldo Sichieri- EESC-USP

CAVALCANTI, L. Quando o Brasil era moderno: guia de arquitetura 1928-1960. Rio de Janeiro: Aeroplano, 2001.

CERÁVOLO, A.L. Paulo de Camargo e Almeida: arquitetura total na trajetória profissional de um arquiteto brasileiro. 2000. 243p. Dissertação (Mestrado) - Escola de Engenharia de São Carlos, Universidade de São Paulo, São Carlos, 2000.

CHAUÍ, M. Seminários: o nacional e o popular na cultura brasileira. São Paulo: Brasiliense, 1983.

COMAS, C.E.; CANEZ, A.P.; BOHRER, G.V. Arquiteturas cisplatinas: Roman Fresnedo Siri e Eladio Dieste em Porto Alegre. Porto Alegre: UniRitter, 2004. 
REFERÊNCIAS

CONHEÇA a USP. 2008. Disponível

em:<http://www.radio.usp.br/programa.php?id=5\&edicao=050603>. Acesso em: $10 / 11 / 2207$

COSTA, L. Lucio Costa: registro de uma vivência. São Paulo: Empresa das Artes, 1995.

Sobre arquitetura. Porto Alegre: Centro dos Estudantes Universitários de Arquitetura, 1962.

FERRAZ, G. Warchavchik e a introdução da nova arquitetura no Brasil: 1925 a 1940. São Paulo: Habitat, 1965.

FORSEE, A. Frank Lloyd Wright, su vida y su obra. Buenos Aires: Victor Leru, 1960.

FRAMPTON, K. "Frank Lloyd Wright and the text-tile tectonic" in studies in tectonic culture. The Poetics of construction in nineteenth and twentieth century architecture. London: John Cava, 1995.

História crítica da arquitetura moderna. São Paulo: Martins Fontes, 1997.

FUJIOKA, P.Y. Princípios da arquitetura organicista de Frank Lloyd Wright e suas influências na arquitetura moderna paulistana. 2003. 313p. Tese (Doutorado) Faculdade de Arquitetura e Urbanismo, Universidade de São Paulo, São Paulo, 2004.

GIMENEZ, L.E. Arquitetura paulistana da década de 1960: técnica e forma. 2004. 250p. Tese (Doutorado) - Faculdade de Arquitetura e Urbanismo, Universidade de São Paulo, São Paulo, 2004.

GUERRA, A. (Org.). Eduardo de Almeida: arquiteto brasileiro contemporâneo. São Paulo: Romano Guerra, 2006.

HITCHCOCK, H.R. Frank Lloyd Wright: obras 1887-1941. Barcelona: Gustavo Gili, 1978.

IRIGOYEN DE TOUCEDA, A.M. Frank Lloyd Wright e o Brasil. 2000. 146p.

Dissertação (Mestrado) - Escola de Engenharia de São Carlos, Universidade de São Paulo, São Carlos, 2000.

IRIGOYEN DE TOUCEDA, A.M. Frank Lloyd wright e o Brasil. Dissertação de mestrado. São Carlos, EESC-USP, 2000

IRIGOYEN, A. Wright e Artigas: duas viagens. São Paulo, Ateliê Editorial/FAPESP 2002

IRIGOYEN DE TOUCEDA, A.M. Da Califórnia a São Paulo: referências norte americanas na casa moderna paulista 1945-1960. Tese de doutorado, FAU-USP, 2005

KATINSKY, J.R. Vilanova Artigas: invenção de uma arquitetura. São Paulo: Instituto Tomie Ohtake, 2003.

KOURY, A.P. Grupo arquitetura nova: Flávio Império, Rodrigo Lefèvre e Sérgio Ferro. São Paulo: Romano Guerra; EDUSP, 2003. 
Arquitetura construtiva: proposições para a produção material da arquitetura contemporânea no Brasil. 2005. 296p. Tese (Doutorado) - Faculdade de Arquitetura e Urbanismo, Universidade de São Paulo, São Paulo, 2005.

Grupo arquitetura nova. 1999. 139p. Dissertação (Mestrado) - Escola de Engenharia de São Carlos, Universidade de São Paulo, São Carlos, 1999.

LANNA, A.L.D. (Org.). Cidades Universitárias: patrimônio urbanístico e arquitetônico da USP. São Paulo: EDUSP, 2005.

LEÃO, R.M. 30 anos em CENA. São Paulo : EDUSP; Piracicaba: CENA, 1996.

LIMA, L.G.C. A Elaboração dos organogramas funcionais a partir da álgebra de Boole e da Teoria dos Grafos. [S.I.:S.n.], 1956.

- A Problemática habitacional latinoamericana. In: CONFERENCIA LATINOAMERICANA DE ESCUELAS Y FACULTADES DE ARQUITECTURA, 3., 1989, San Carlo. Catalogo... San Carlo: Universidad de San Carlos, 1989.

Nov./dez. 1958.

O Equipamento da habitação (introdução). Bem Estar, São Paulo, v.1, n.3, p. Comunicação visual e metodologia para o ensino do desenho. 1973. 84p. Tese (Doutorado) - Faculdade de Arquitetura e Urbanismo, Universidade de São Paulo, São Paulo, 1973.

. Informação, comunicação e linguagem. São Carlos: CPD/EESC/USP, 1967.

. In TAMASHIRO, H.A. Desenho Técnico arquitetônico: constatação do atual ensino nas escolas brasileiras de arquitetura e urbanismo. Dissertação de Mestrado. EESC-USP, 2003 p.227-243 (entrevista concedida ao autor em 20/11/2002)

MARTINS, M.H.P. A Escola de Comunicação e Artes e sua história. Comunicações e Artes, São Paulo, v.22, p.29-52, nov. 1989.

McCARTER, R. Frank Lloyd Wright. London: Phaidon, 1999.

MELO, V. de. A obra folclórica de Cascudo como expressão do movimento modernista no Brasil, col. Mossoroense, no 643, 1989

MINDLIN, H.E. Modern architecture in Brazil. New York: Reinhold, 1956.

MUMFORD, P. Frank Lloyd Wright e outros escritos. Buenos Aires: Infinito, 1959.

NOSELLA, P.; BUFFA, E. Universidade de São Paulo, Escola de Engenharia de São Carlos: os primeiros tempos - 1948-1971. São Carlos: EDUFSCAR, 2000.

PATTERSON, T.L. Frank Lloyd Wright and the meaning of materials. New York: Van Nostrand Reinhold, 1994.

PFEIFFER, B.B. Frank Lloyd Wright. Koln: Benedikt Taschen, 2000.

PORTO, F.A. Odontologia de equipe. 1975. Tese (Livre-Docência) - Faculdade de Odontologias, Universidade de São Paulo, Bauru, 1975. 
REIS FILHO, N.G. Quadro da arquitetura no Brasil. São Paulo: Perspectiva, 1970. REVISTA HABITAT, São Paulo, n.14, fev.1954.

SCULLY JR, V. Arquitetura moderna: a arquitetura da democracia. São Paulo: Cosac \& Naify, 2002.

SEGAWA, H. Arquiteturas no Brasil - 1900-1990. São Paulo: EDUSP, 1998.

SMITH, N.K. Frank Lloyd Wright: a study in architectural content. Englewood Cliffs: Prentice-Hall, 1966.

SOUZA, A. Arquitetura no Brasil: depoimentos. São Paulo: Diadorim; EDUSP, 1978.

TAMASHIRO, H.A. Desenho técnico arquitetônico: constatação do atual ensino nas escolas brasileiras de arquitetura e urbanismo. EESC-USP, 2003. Dissertação de Mestrado

TWOMBLY, R.C. Frank Lloyd Wright: his life and his architecture. New York: John Wiley, 1979.

UNIVERSIDADE DE SÃO PAULO. Faculdade de Arquitetura e Urbanismo.

Departamento de Projeto. Desenho industrial 1962: seqüência de desenho industrial. São Paulo: FAU/USP, 1963. (Publicação 8).

VAN ECK, C. Organicism in the nineteenth-century architecture. Amsterdam: Architectura \& Natura, 1994.

XAVIER, A.; LEMOS, C.A.C.; CORONA, E. Arquitetura moderna paulistana. São Paulo: Pini, 1983.

XAVIER, A.F.M. Depoimento de uma geração: arquitetura moderna brasileira. São Paulo: Cosac \& Naify, 2003.

ZEIN, R.V. Brutalismo, sobre sua definição (ou, de como um rótulo superficial é, por isso mesmo, adequado). Disponível em:<http://www.vitruvius.com.br/arquitextos/arq084/arq084 00.asp $>$. Acesso em: $10 / 11 / 2007$

ZEVI, B. Storia dell'architettura moderna. 3.ed. Torino: Giulio Einaudi, 1955.

Towards an organic architecture. London: Faber and Faber, 1949.

Saber ver a arquitetura. São Paulo: Martins Fontes, 1978. 
- BORTOLUCCI, Maria Ângela. Entrevista concedida à autora em 04/12/2007. São Carlos, SP. ${ }^{1}$

- CAMAROTTO, João Alberto. Entrevista concedida à autora em 16/02/2008. São Carlos-SP. ${ }^{2}$

- GOMES, José Cláudio Gomes. Entrevista concedida à autora em 05/06/2007 São Paulo-SP. ${ }^{3}$

- INSTITUTO DOS ARQUITETOS DO BRASIL - São Paulo. Arquitetura e desenvolvimento nacional: depoimentos de arquitetos paulistas. Pini, São Paulo, 1979.

- INSTITUTO DE ARQUITETOS DO BRASIL - Departamento do Rio de Janeiro. II Inquérito Nacional de Arquitetura: depoimentos. Rio de Janeiro: IAB, 1982

- LAVOIE, Luis Paulo. Entrevista concedida à autora em 31/10/2007

- LIMA, Flávia de Castro. Entrevista concedida à autora em março de 2007 e correspondências trocadas via e-mail. ${ }^{5}$

- LIMA, Luiz Gastão de Castro. Aula Prof. Gastão e Prof. Caron. EESC-USP. Aula gravada em vídeo-tape. CEDOC. EESC-USP. s/d (data provável:1997)

- MARTINS, Carlos Alberto Ferreira. Entrevista concedida à autora em 12/04/2007. São Carlos, SP. ${ }^{6}$

- MARTINHO, Araquém. Entrevista concedida à autora em 01/05/2008. Jundiaí, SP.

- OTONNI, Dácio Araújo Benedicto. Entrevista concedida à autora em 2006. São Paulo, SP. ${ }^{7}$

\footnotetext{
${ }^{1}$ Maria Ângela é arquiteta e Professora da EESC-USP. Foi orientanda, amiga e colega de trabalho do arquiteto na EESC e na UNESP.

${ }^{2}$ Camarotto é graduado em Engenharia Mecânica pela Universidade de Brasília (1976), professor da Universidade Federal de São Carlos, foi orientando de doutorado e colega de trabalho do arquiteto na UFSCar.

${ }^{3}$ José Cláudio Gomes é arquiteto, formado pela FAU-USP em 1953. Fez parte do grupo de wrightianos da FAU. Foi colega de trabalho e amigo de Luiz Gastão de Castro Lima na EESC e na UNESP em Bauru.

${ }^{4}$ Luis Paulo Lavoie é filho de Rock Lionel Lavoie, sócio fundador da DIAMANTUL S.A, onde Luiz Gastão de Castro Lima trabalhou durante o ano de 1964. Anos mais tarde, Lavoie contrata novamente o arquiteto para o projeto da fábrica da Wirth Latina.

${ }^{5}$ Flávia de Castro Lima é esposa do arquiteto e nos recebeu com enorme gentileza em sua residência por duas vezes, prestando seu depoimento e permitindo registros fotográficos. Durante toda a pesquisa, trocamos correspondência via e-mail, na busca de elucidar e compreender alguns aspectos da vida e obra de Luiz Gastão.

${ }^{6}$ Carlos Martins é arquiteto e professor da EESC-USP, participou junto ao arquiteto da criação do departamento de Arquitetura e Planejamento da EESC.
} 
- ROCHA Fo, Gustavo Neves da. "A origem remota do AUH". Texto fornecido ao Prof. Lúcio Gomes Machado. s/d

- ROHM, José Alfeu. Entrevista concedida à autora em 22 de fevereiro de 2008. São Carlos-SP. ${ }^{8}$

- SADER, Jamil Calil e Maguita Sader. Entrevista concedida à autora em 16/04/2008, em Jaboticabal-SP. ${ }^{9}$

- CONTADOR, José Celso. Correspondência trocada entre José Celso Contador e a autora via e-mail, em outubro de $2007 .{ }^{10}$

- Currículo do arquiteto. Acervo LIEP-UFSCAR

- Processo no 11.174/61.7 Universidade de São Paulo

- Processo no 6581/56 Universidade de São Paulo

- Processo no 453/64 Universidade de São Paulo

- Processo no 30.974/64 Universidade de São Paulo

- Processo no 3488/65 Universidade de São Paulo

- Processo no 5543/65 Universidade de São Paulo

- Processo no 19130/66 Universidade de São Paulo

- Processo no 957/76 Universidade Federal de São Carlos

- Processos de aprovação de projeto. Prefeitura Municipal de São Carlos.

- Pasta 1a Bienal de São Paulo. Arquivo Histórico Wanda Svevo. São Paulo. Fundação Bienal. 1951

- Relatório das atividades de docência e pesquisa do docente Luiz Gastão de Castro Lima - Universidade de São Paulo.

\footnotetext{
${ }^{7}$ Arquiteto, formado pela FAU-USP em 1960 e membro do grupo wrightiano, Ottoni foi colega e amigo do arquiteto.

${ }^{8}$ José Alfeu Rohm foi responsável pelo LIEP (Laboratório Integrado do Produto da UFSCar) do curso de Engenharia de Produção da Universidade Federal de São Carlos. Foi colega de trabalho e amigo do arquiteto. O final da entrevista foi assistido por Nazaré Rohm, esposa de José Alfeu Rohm, que também privou de sua amizade. Nazaré Rohm contribui fornecendo dados importantes.

${ }^{9}$ Médico, ex-prefeito de Jaboticabal, Sader e sua esposa Maguita (que participou ativamente da entrevista) foram clientes e amigos do arquiteto.

${ }^{10}$ José Celso Contador, engenheiro, foi amigo e cliente de Luiz Gastão de Castro Lima.

Trabalhou junto à Construtora COCIBRA
} 


\section{ANEXO1}
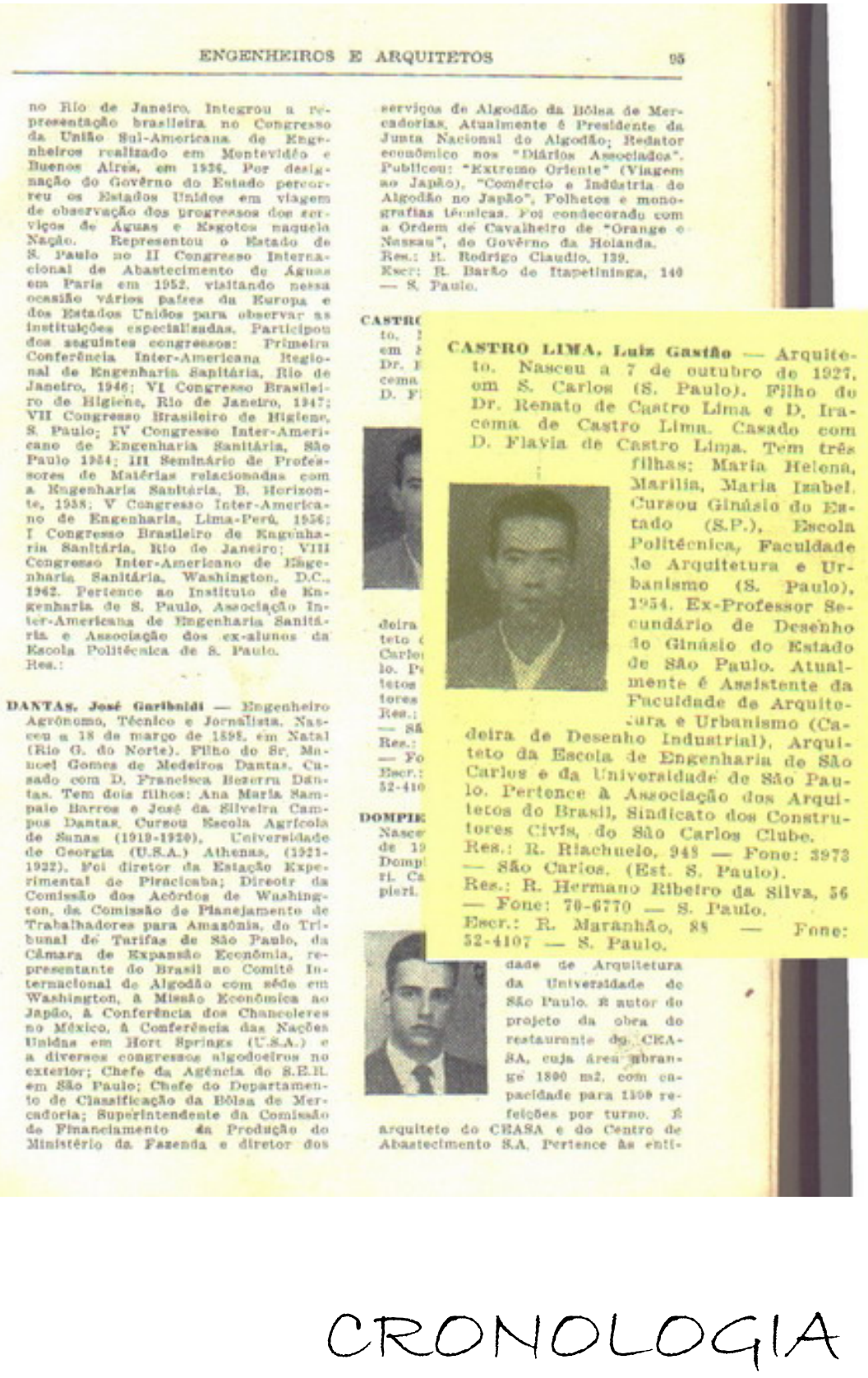


\section{7}

Nasce em São Carlos, em 07 de outubro, Luiz Gastão de Castro Lima, filho de Iracema e Renato de Castro Lima. Poucos anos depois, a família se transfere para São Paulo.

\section{8}

Mario de Andrade publica Macunaíma. Oswald de Andrade publica o Manifesto Antropófago no primeiro número da recém-fundada Revista de Antropofagia, veículo de difusão do movimento antropofágico brasileiro. Paulo Prado escreve "Retrato do Brasil" onde aponta a tristeza, o romantismo, a luxúria e o vício da imitação como os maiores problemas da nacionalidade.

\section{9}

Inaugurado em de São Paulo o Edifício Martinelli, o maior da América Latina, com 30 andares.

Le Corbusier visita o Brasil, faz estudos urbanísticos para São Paulo e Rio de Janeiro e profere palestras na ENBA.

Quebra da bolsa de Nova York

\section{0}

Lúcio Costa é nomeado diretor da ENBA e inicia uma reforma no ensino de arquitetura.

Explode a Revolução de 30. Um levante armado depõe Washington Luís e Getúlio Vargas toma posse como chefe do governo provisório.

O governo determina a queima de milhares de sacas de café, numa tentativa de elevar o preço do produto no mercado internacional. Sem dinheiro para honrar os compromissos externos, o Brasil decreta a sua primeira moratória.

O ensino da língua inglesa torna-se obrigatório quebrando o predomínio do francês nas escolas secundárias, enquanto mais de $60 \%$ dos brasileiros ainda são analfabetos.

O dirigível Graf Zeppelin aporta no Rio de Janeiro e no alto do Corcovado é inaugurada a estátua do Cristo Redentor, projeto do arquiteto francês Paul Landowski. Em 12 de outubro, de uma estação radiotelegráfica em Gênova, partem ondas eletromagnéticas que iluminam a estátua do Cristo do outro lado do oceano.

\section{1}

À frente de uma comissão formada por Anita Malfatti, Manuel Bandeira, Celso Antônio e Cândido Portinari, Lúcio Costa promove a XXXVIII Exposição Geral de Belas Artes, que ficou conhecida como Salão Revolucionário de 1931.

José Mariano Filho lidera uma campanha contra Costa, que culmina com a demissão do arquiteto poucos dias após a abertura do Salão.

Tem início a greve de estudantes na ENBA em protesto à demissão sumária de Lúcio Costa.

Frank Lloyd Wright vem pela primeira vez ao Brasil, como membro do júri do Concurso para o Farol de Colombo. Na ocasião profere palestras na ENBA e apóia os estudantes a favor de Lúcio Costa.

1932

Eclode a Revolução Constitucionalista visando à derrubada do governo provisório de Getúlio Vargas. 

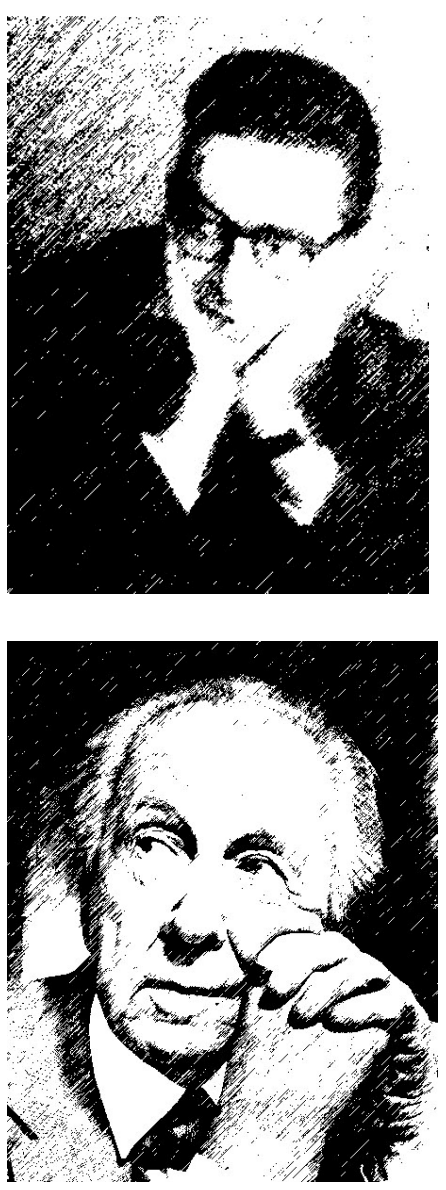

1933

Tem início nos EUA, o New Deal .Hitler torna-se o $1^{\circ}$ ministro alemão

\section{6}

Realizada pela BBC de Londres, a primeira transmissão de imagens por ondas.

\section{7}

Em 30 de novembro é o criado o SPHAN que definiu o patrimônio histórico e artístico nacional como o conjunto de bens vinculados a fatos memoráveis da História do Brasil, de valor arqueológico ou etnográfico, bibliográfico ou artístico e monumentos naturais dotados pela natureza ou agenciados pela indústria humana.

1939

Hitler invade a Polônia. Tem início a Segunda Guerra Mundial.

\section{1}

Ataque japonês a Pearl Harbour precipita a entrada dos EUA na Guerra.

\section{2}

Gastão conclui os estudos do curso secundário.

O Brasil declara guerra aos países do Eixo. Se une às forças aliadas e inicia um estreitamento de relações com os Estados Unidos.

\section{3}

Luiz Gastão ingressa no Colégio do Estado, concluindo o colegial em 1945.

\section{5}

Fim da Segunda Guerra após os ataques atômicos à Yroshima e Nagasaki.

\section{7}

Luiz Gastão ingressa na Escola Politécnica.

Pela mãos de Assis Chateaubriand, é criado o Museu de Arte de São Paulo (MASP)

\section{8}

É criada a FAU - Faculdade de Arquitetura da USP

É criado o Museu de Arte Moderna de São Paulo (MAM) pelo industrial Francisco Matarazzo Sobrinho.

Lúcio Costa publica um artigo no primeiro número da revista Cultura, onde aborda a problemática do ensino do desenho no curso secundário, que na época passava por reformulações.

\section{9}

Depois de dois anos na Poli, Gastão deixa o curso de engenharia e ingressa na recém criada Faculdade de Arquitetura da USP, contrariando sua família que desejava ter um filho Engenheiro.

Faz o curso de História da Arte ministrado por Pietro Maria Bardi, para trabalhar como monitor do MASP.

Ao lado de Antonio Carvalho, Plínio Venanzi, José Cláudio Gomes, Toshio Tone e Roberto Pinto Monteiro fundam o Centro de Estudos Folclóricos (CEF) da FAU.

Em oito de março é inaugurado o MAM com a exposição "Do Figurativismo ao Abstracionismo". 


\section{0}

Luiz Gastão recebe menção honrosa no Concurso de Cartazes para a $1^{\text {a }}$ Bienal Internacional de Arquitetura de São Paulo, onde se inscreve com três desenhos sob o pseudônimo de Macunaíma.

Getúlio Vargas é eleito presidente

\section{1}

Acontece na esplanada do Trianon, a1aㅡ Bienal Internacional de Artes de São Paulo.

\section{3}

Gastão inicia sua vida docente como professor secundário de Desenho no Ginásio da rede pública de ensino de Indianápolis EE Prof Alberto Levi, onde leciona até 1956.

Nasce Marília, sua primeira filha com Flávia de Castro Lima.

É criada a Escola de Engenharia de São Carlos (EESC), instalada inicialmente em prédio cedido pela "Societá Dante Alighieri".

\section{4}

Gastão se forma na FAU ao lado de Joaquim Guedes, Toshio Tone, Ariaki Kato e Ginez Velanga.

São Paulo comemora seu IV Centenário e inaugura o Parque do Ibirapuera, projeto de Oscar Niemeyer com a colaboração de Carlos Lemos, Zenon Lotufo e Eduardo Corona.

Acontece em São Paulo, a $2^{\text {a }}$ Bienal contando com uma Mostra Internacional de Arquitetura.

Jânio vence as eleições para o governo paulista e Vargas comete suicídio.

1955

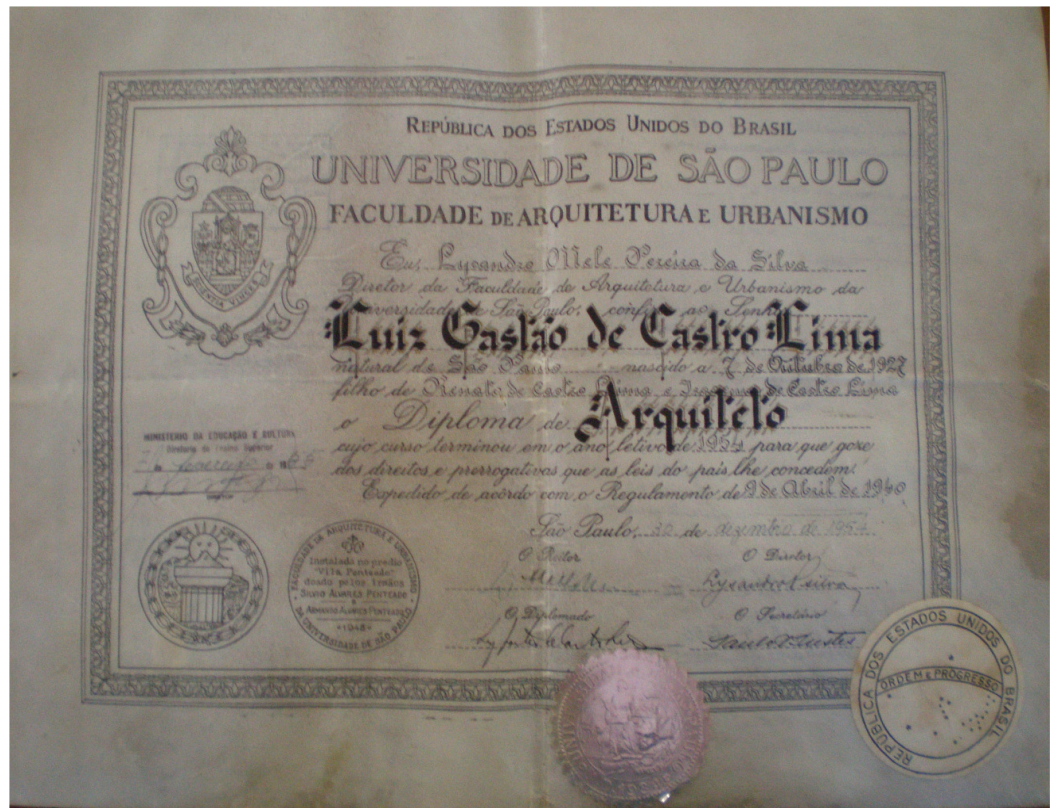

Luiz Gastão de Castro Lima. Diploma de Arquiteto. FAU-USP. Fonte:

Gastão viaja ao Peru a convite do Arquiteto Fernando Belaunde Terry. Na ocasião vai também à Argentina e ao Chile, a fim de documentar a arquitetura produzida nos dois países.

Recebe bolsa de Estudos do Governo Italiano para freqüentar o curso de desenho industrial na Faculdade de Arquitetura da Universidade de Florença, mas desiste da bolsa.

Juscelino Kubitschek é eleito presidente pelo voto direto. 


\section{6}

Nasce Maria Isabel, segunda filha de Luiz Gastão e Flávia de Castro Lima. A convite de José Maria da Silva Neves é contratado como professor assistente junto à cadeira no 22 de Composição Decorativa pela FAU.

É instalada a Indústria automobilística no Brasil com a fabricação da RomiIsetta, primeiro automóvel fabricado inteiramente no país.

\section{7}

Gastão profere palestra sobre Arquitetura Japonesa na FAU e publica trabalho sobre o mesmo tema em órgão interno da Instituição. (publicação não localizada)

A EESC inicia a implantação do novo campus com a construção do Bloco E-1, edifício de expressão corbusiana.

Tem início a guerra do Vietnã

\section{9}

Morre Frank Lloyd Wright. O grupo de corbusianos da FAU faz um enterro simbólico, como provocação ao grupo wrightiano. Este, promove uma exposição com obras do mestre norte-americano.

Ocorre de 17 a 25 de setembro em São Paulo, Rio e Brasília o Congresso Internacional Extraordinário dos Críticos de Arte com a presença de Bruno Zevi. Na ocasião, Zevi faz críticas às cidades planejadas.

Tem início em São Paulo, o governo de Carvalho Pinto e o Plano de Ação.

\section{0}

Luiz Gastão é indicado pelo diretor da EESC Theodureto de Arruda Souto para acompanhar as obras no campus.

Nasce Maria Helena, sua terceira filha. Gastão se transfere com a família para São Carlos.

Recebe o 4 Prêmio no Concurso de Ante Projetos para o Ginásio de São Caetano do Sul.

É montado no Anhembi, o primeiro Salão Internacional do automóvel. Inauguração de Brasília

1961

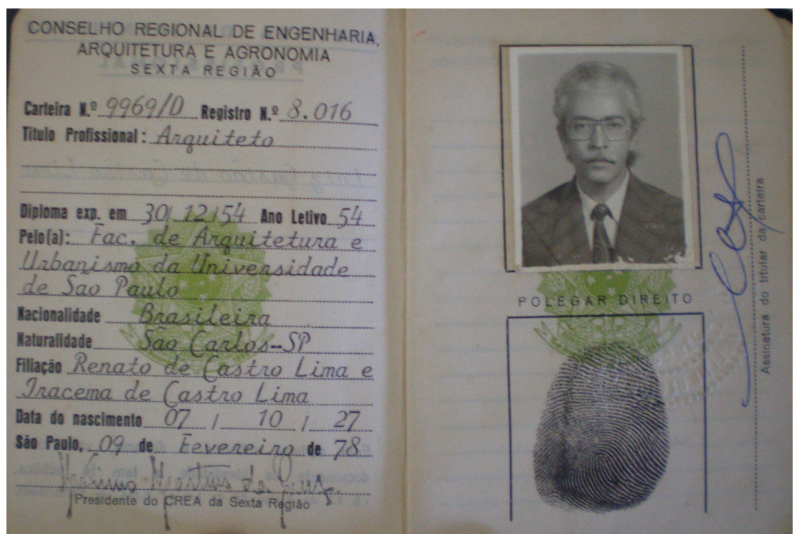

Luiz Gastão de Castro Lima. CREA . Carteira

Profissional. Fonte: acervo do arquiteto. LIEP-UFSCar

Projeta o Laboratório de Análises Clínicas Dr Gastão Fleury Silveira da Rua Cincinato Braga e a Casa Eduardo Pellegrini em São Paulo (esta última demolida) É dado início na EESC a uma série de obras oriundas do Plano de Ação do Governo Carvalho Pinto. Gastão projeta o Restaurante e Centro Social, Anfiteatros e salas de aula, Habitação de alunos e reforma o prédio para o Centro de Processamento de dados da Escola. 


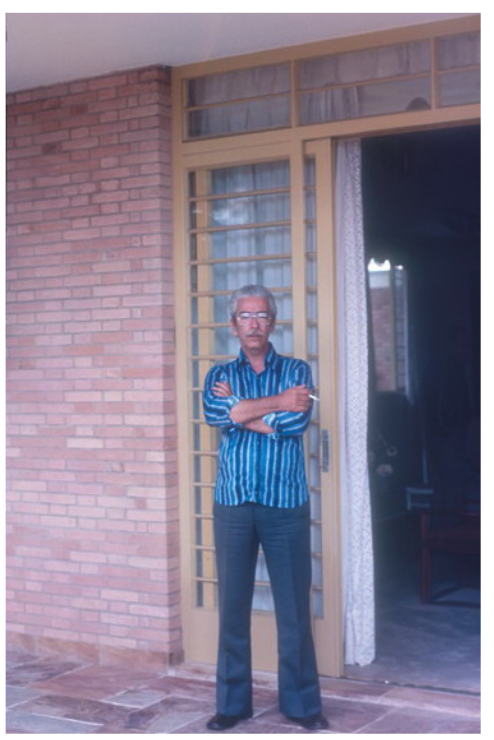

Vilanova Artigas e Carlos Cascaldi elaboram o projeto da FAU-USP. Flávio Império projeta a Casa Simão Fausto em Ubatuda e Sérgio Ferro a Casa Bernardo Issler em Cotia.

\section{2}

Projeto da Residência Lia, em Araraquara

Gastão participa do Seminário "Lineamento com o emprego de cônicas e tecnologia dos plásticos reforçados com fibra de vidro" - EESC - este seminário teve como objetivo o treinamento para montagem da Seção de Plásticos da FAU (anexa às cadeiras de Desenho Industrial e Comunicação Visual)

Encabeçada por Vilanova Artigas, tem início a reforma curricular no Ensino de Arquitetura na FAU. Na ocasião se estabelecem os fundamentos da estrutura de ensino que posteriormente viriam a formar os três departamentos: Projetos, História e Tecnologia. Com a reforma curricular, a cadeira de "Composição decorativa" ocupada por Luiz Gastão passa a se chamar "Desenho Industrial III"

\section{3}

Profere a palestra "Raízes da Arte Contemporânea" no Instituto Álvaro Guião e projeta os Anfiteatros e Departamentos de Mecânica da ESALQ. Carvalho Pinto chega ao fim do mandato.

O presidente Kennedy é assassinado nos EUA.

\section{4}

Com o fim do governo Carvalho Pinto no ano anterior, Gastão é exonerado do cargo de Arquiteto do campus e ingressa como docente na EESC.

Profere a palestra "A iluminura medieval" na Escola de Biblioteconomia e Documentação de São Carlos.

Projeto da Biblioteca Central da ESALQ. Realiza trabalhos de Desenho Industrial junto à empresa Diamantul, participando de todo processo de projeto, fabricação, embalagem e transporte do produto.

Um golpe militar dá início à ditadura no Brasil.

\section{5}

A convite da Faculdade de Arquitetura de Porto Alegre da UFRGS profere seminário sobre "Modelos plásticos reforçados com fibra de vidro" com o objetivo de introduzir esta técnica no setor de Desenho Industrial e instruir professores, profissionais e artistas sobre as possibilidades dos plásticos e sua tecnologia usual.

Ministra o curso Elementos de Desenho Industrial na Pós Graduação em "Elementos de Máquinas e Desenho Industrial" na ESALQ em Piracicaba. Projeta o prédio do CENA (Centro de Energia Nuclear) e do Centro de Estudos de Solos da ESALQ. Piracicaba

O General Castelo Branco leva sonora vaia em aula inaugural na UFRJ.

A UNB assiste a protestos anti-ditadura. A PM invade o Crusp (alojamento estudantil) em represália à greve estudantil na USP. A PUC-SP inaugura o auditório do Tuca com o auto de denúncia e esperança Morte e Vida Severina, com versos de João Cabral de Melo Neto, música de Chico Buarque.

O Brasil se integra ao sistema Intelsat e são criadas a Embratel e a Rede Globo.

O estilista francês André Courrèges mexe com a moda ao apresentar sua coleção primavera-verão, recheada de vestidos de linhas retas, botas e aquela que viria a se tornar a vedete da década, a minissaia. 


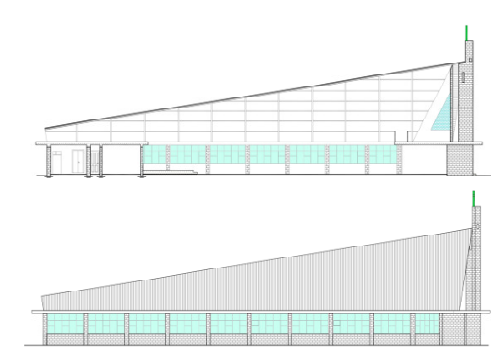

Igreja N. S. de Fátima. Vila Pureza, São Carlos
O primeiro festival de música premia Arrastão, de Edu Lobo e Vinícius de Moraes, interpretada por Elis Regina.

\section{6}

Gastão inicia o doutorado. Faz duas disciplinas na FAU: "Metadesign" e "Introdução à teoria da Comunicação" ministrado por Ernest Robert de Carvalho Mange.

Se torna membro da Comissão de Coordenação e Planejamento da EESC e substitui José Maria da Silva Neves regendo a cátedra Desenho Industrial III na FAU.

Projeto da Igreja Nossa Senhora de Fátima em Vila Pureza em São Carlos, Residência Wilson Senise e São Carlos Clube (sede de campo):

administração, portaria, salão social e auditório, este último não construído. As obras do teatro Municipal de São Carlos são retomadas. Gastão participa da empreitada como voluntário.

Acontece eleições indiretas para governador em doze estados brasileiros. A ditadura vence em todos.

Criado o FGTS (Fundo de Garantia por Tempo de Serviço) e decretado o fim da estabilidade nas empresas privadas.

Lançada no Rio de Janeiro, a Frente Ampla, unindo Lacerda, Goulart e JK. Jorge Amado publica Gabriela Cravo e Canela e Dona Flor e Seus Dois Maridos enquanto Chico Buarque e Nara Leão movimentam a MPB com $A$ banda

A guerra do Vietnã ganha contornos dramáticos.

\section{7}

Projeto do Clube Municipal de Guaira, Casa Nelson Onishick na Rua Paulo Botelho Sampaio. É provado no concurso de pós-graduação de Projeto na USP "Metadesing e Introdução à Teoria da Comunicação". Faz curso de especialização em "Programação FORTRAN IV" na EESC.

Recebe $02^{\circ}$ Prêmio no Concurso de Projetos para remodelação da Praça Coronel Salles, em São Carlos.

Desenvolve trabalho de Planejamento, pré-fabricação e paisagismo na Fazenda Sapé, primeira tentativa nacional de industrialização da Pecuária em conceitos de Pecuária Intensiva Internacional.

O General Castelo Branco sanciona sob protestos de intelectuais, artistas e jornalistas, a nova lei de censura da imprensa que atingiu não apenas periódicos, mas também a radiodifusão. Pouco tempo depois Castelo Branco é substituído na presidência por Artur da Costa e Silva.

É criado o Ministério das Comunicações e instalada a discagem direta a distância (DDD), as transmissões de TV de âmbito nacional, as transmissões internacionais (via satélite), a televisão em cores e a discagem direta internacional (DDI)

É criada a Universidade Estadual de Campinas (UNICAMP) Inaugurado em São Paulo o Museu Lasar Segall e reaberto o Teatro Oficina, com a comédia O Rei da Vela, de Oswald de Andrade.

\section{8}

Gastão vai ao Distrito Federal em outubro, como representante da FAU no Seminário de Reestruturação do Instituto Central de Artes de Brasília e é eleito representante dos Instrutores da USP no Conselho Universitário.

Projeta o Hospital São Marcos em Jaboticabal e as residências José Celso Contador, Silvio Montmorency e Nilson Gandolti em São Carlos, e em Jaboticabal: as casas Jamil Sader e Marry Junior.

É criada a Fundação Universidade Federal de São Carlos. 


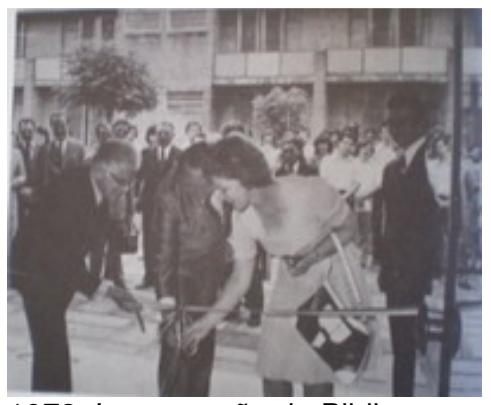

1973. Inauguração da Biblioteca Central da EESC. Ao fundo, a imagem do alojamento
Greve geral na França. A rebeldia estudantil e operária ecoa no Brasil e no mundo.

Em agosto, a UNB é invadida pela terceira vez. O governo edita o Ato Institucional no 5 (Al-5)

Manifestações estudantis e artísticas são reprimidas em várias cidades do país. Estudantes secundaristas e universitários são reprimidos violentamente no restaurante Calabouço (RJ) pela Polícia Militar.

Caetano lança o LP "Tropicália" ou "Pane et Circenses" e, no mesmo ano, se apresenta com os Mutantes no Tuca, em São Paulo, com a música "É Proibido Proibir", sob vaias e tomates lançados ao palco.

Lançado o filme Yellow Submarine no formato de desenho animado.

A sonda espacial norte-americana Surveyor 7 aterrisa na superfície lunar.

O primeiro homem pisaria na Lua no ano seguinte.

Computador e habilidade humana passam a andar juntos após a invenção do mouse.

\section{9}

Gastão projeta a Biblioteca Central da EESC, Departamento de Matemática e a Residência Miguel Abdelnur Filho em São Carlos.

Em 15 de abril, pede exoneração do cargo de instrutor em substituição junto à Cátedra Arquitetura e Planejamento da EESC, prendendo-se ao fato de estar em vias de assinar contrato em regime de dedicação exclusiva com a UNB, como professor titular do Instituto Central de Artes da Universidade. Gastão não ficaria em Brasília por mais de um ano.

Após obras precárias e improvisos, é oficialmente inaugurado o teatro Municipal de São Carlos Alderico Vieira Perdigão, com Cacilda Becker em uma de suas últimas atuações.

Lançado o jornal O Pasquim, reduto do humor no auge da ditadura. É determinada a apreensão de livros, jornais, revistas e outras publicações que atentam contra o regime militar.

O Festival de Woodstock_reúne 800 mil jovens no auge do movimento hippie.

É criada a Empresa Brasileira de Correios e Telégrafos e a EMBRAER. Emílio Garrastazu Médici é eleito presidente pelo Congresso Nacional. Neil Armstrong e Edwin Aldrin são os primeiros homens a pisar na Lua A Darpa (agência de pesquisas do Pentágono) inaugura a Internet, rede de computadores projetada para sobreviver a uma guerra nuclear.

\section{0}

Gastão participa de curso de extensão universitária com palestras de Abraham Moles na FAAP.

É aprovado em Concurso de Títulos para professor da disciplina "Artes Visuais" da Escola de Comunicação e Artes da USP (ECA).

É Coordenador do grupo de disciplinas de Programação Visual da Faculdade de Arquitetura e Urbanismo da USP e do Setor de Comunicação Visual coordenando a exposição da FAU na $2^{\underline{a}}$ Bienal de Desenho Industrial e Comunicação Visual, no museu de arte Moderna da Guanabara.

Na década de 70 realiza uma série de intervenções no Hotel Azouri, época em que este passa a ser administrado pelo grupo Vila Rica.

Projeto da Clínica Odontológica Especializada - COE - São Carlos.

Fundada a Universidade Estadual de Londrina, integrando as faculdades de Filosofia, Ciência e Letras

Em sua primeira visita a São Paulo, o presidente Emílio Garrastazu Médici inaugura a Praça Roosevelt e o Estádio do Morumbi. 
John Lennon, numa entrevista ao jornal Rolling Stones, aos 30 anos de idade, declara The Dream is Over, frase cheia de significados no contexto da época, que será depois apropriada por Gilberto Gil no LP Expresso 2222.

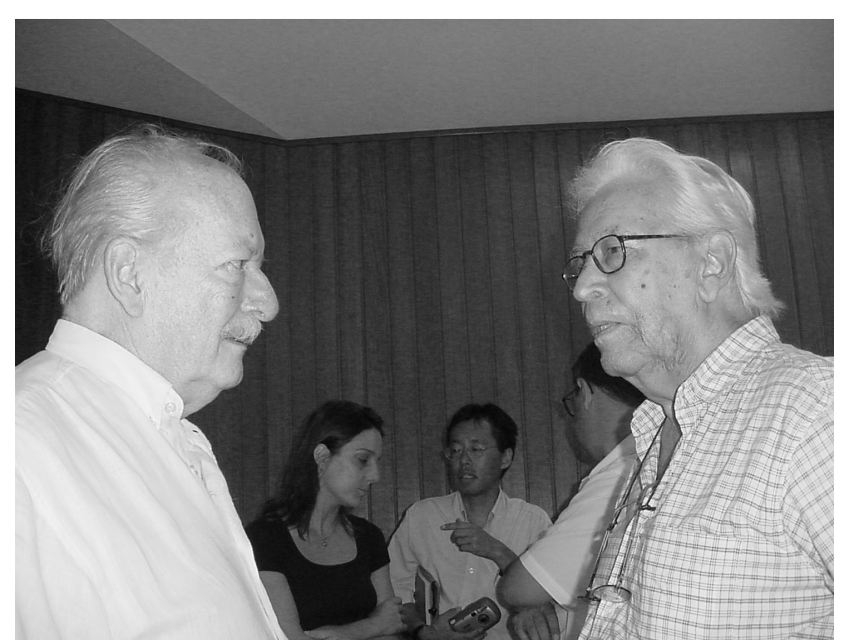

Aula Magna na EESC, em 03/05/2002. Luiz Gastão e Ernest Mange. Ao fundo, Hugo Segawa. Foto cedida pelo arquiteto Julio César Alves Ferreira

1971

Gastão ingressa a partir de março, como professor adjunto na Escola de Engenharia de Bauru ministrando as disciplinas "Arquitetura e Construção de Edifícios".

Coordena o grupo de disciplinas de Programação visual da FAUUSP

Ministra a disciplina de Pós-graduação "Arquitetura e Comunicação Visual" do curso de pós-graduação "Industrialização das Construções do Departamento de Arquitetura e Planejamento da EESC

Ministra o curso de Extensão Universitária "Introdução às Teorias da Comunicação e Comunicação Visual" na faculdade de Filosofia de Penápolis e na Faculdade de Ciências da Fundação Educacional de Bauru. Profere palestra "O Desenvolvimento dos Meios Tecnológicos de Comunicação" em São Paulo, durante o Ciclo "Revolução na Comunicação" e a palestra "Comunicação e Cultura de Massa" na Fundação Educacional de Bauru. Elabora projeto de programação visual, desenvolve logomarca da empresa COCIBRA e realiza trabalhos de Desenho Industrial e Comunicação Visual para a empresa SAMBRA/SA, elaborando Projeto de utilidade doméstica em mármore.

É produzido o primeiro microship.

O prefeito de São Paulo, Paulo Maluf, inaugura o elevado Presidente Artur da Costa e Silva, que passa a ser conhecido como Minhocão, em São Paulo.

\section{2}

Gastão se desliga da FAU. Nestor Goulart Reis Filho referenda a 18 de abril, despacho concordando com a transferência definitiva de Luiz Gastão para a EESC.

O ensino de pós-graduação é formalmente instituído na Escola.

É criado o $1^{\circ}$ vídeo game e lançada a 1a tela colorida VCR.

Desenvolvidos os primeiros sistemas para ligar computadores em rede mundial. O Brasil chega aos 100 milhões de habitantes enquanto a Estrada de Ferro Sorocabana é incorporada à Ferrovia Paulista S/A (Fepasa) 


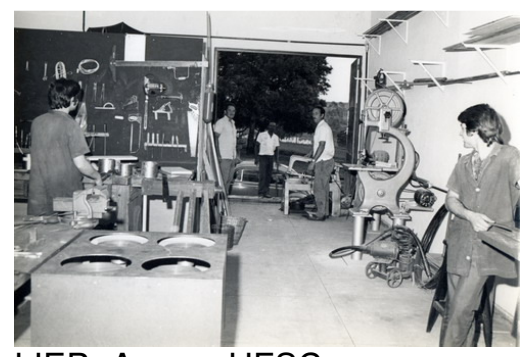

LIEP- Acervo UFSCar

\section{3}

Sem passar pelo Mestrado, Gastão conclui o Doutorado onde defende uma nova metodologia para o Ensino do Desenho nas Escolas de Arquitetura e Engenharia.

Ministra as disciplinas de Desenho Técnico e Desenho Arquitetônico para os cursos de Engenharia Civil, Engenharia Mecânica e Engenharia Elétrica na EESC.

Assume junto a Lafael Petroni a chefia do departamento de Arquitetura na EESC até se aposentar em 86.

É Presidente da Comissão de Assessoramento Didático, instalada para orientar e estruturar os currículos do curso de arquitetura pretendido pela Escola.

Inicia a coordenação e implantação de nova metodologia nos cursos de Desenho, metodologia esta defendida em sua tese de doutoramento.

É firmado um acordo entre Paraguai e Brasil que permite a construção da hidroelétrica de Itaipu.

\section{4}

Gastão desenvolve dois trabalhos para posterior publicação, um sobre a Elaboração dos organogramas funcionais a partir da álgebra de BOOLES e da teoria dos Grafos e o outro sobre Holografia e Comunicação Visual.

Como único docente com titulação de Doutor na área, assume grande carga didática nas disciplinas de Desenho do Departamento de Arquitetura e Planejamento da EESC, sendo responsável por todos os cursos básicos nas engenharias.

Ernesto Geisel é eleito presidente por um colégio eleitoral. Se intensifica a censura aos comerciais de rádio e televisão.

Começa a rodar em São Paulo a $1^{\underline{a}}$ linha do $1^{0}$ metrô do Brasil

\section{5}

Projeto a fábrica da Wirth Latina em São Carlos.

É efetivada a unificação dos antigos Estados da Guanabara e Rio de Janeiro, passando a constituir uma única unidade federativa.

É criado o Programa Nacional do Álcool a fim de estimular o consumo do produto no Brasil

Comunistas tomam a cidade de Saigon e colocam fim à Guerra no Vietnã.

\section{6}

Gastão ingressa como professor adjunto na UFSCAR no departamento de Engenharia de Produção ficando vinculado à Instituição até 1995, onde cria o laboratório do produto (LIEP).

É fundada a Academia de Letras e Música do Brasil (ALMUB)

A Fiat inaugura sua fábrica em Betim.

Juscelino Kubitschek morre em acidente de carro na via Dutra, em circunstâncias não esclarecidas. Seu sepultamento se transforma em manifestação contra a ditadura com cerca de trinta mil pessoas presentes.

\section{9}

Gastão participa do Centro de Estudos Superiores do estado do Pará e recebe em Belém reconhecimento do CREA por sua atuação profissional.

João Baptista Figueiredo assume a presidência prometendo um país democrático "a ferro e fogo". Inúmeras greves sucedem em todo o país 


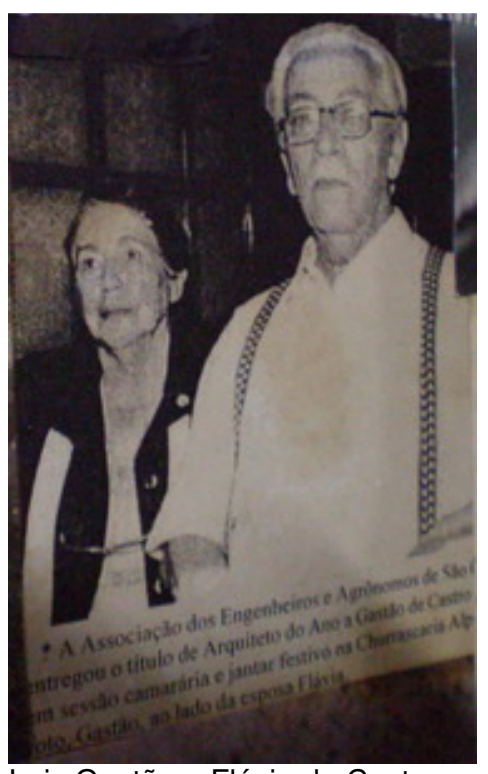

Luiz Gastão e Flávia de Castro Lima. Cerimônia em Homenagem ao arquiteto, na Câmara de Vereadores em São Carlos. 1996. Fonte: acervo do arquiteto

\section{0}

Gastão é eleito presidente da AEASC - Associação dos Engenheiros, Arquitetos e Agrônomos de São Carlos, único arquiteto a ocupar o cargo até hoje.

Começa a grande greve de 330 mil metalúrgicos no $A B C$ e mais 15 cidades em São Paulo.

\section{1}

Gastão ministra o curso "Campo de Comunicação Visual na arquitetura" na Universidade Estadual de Londrina, durante a semana da Cultura.

Desenvolve o tema "COMUNICAÇÂO VISUAL" no programa de Seminários de Estudos Integrados promovido pelo Projeto RONDON e pela Universidade Federal de Alagoas, em Maceió.

Uma bomba explode em atentado no Riocentro durante as comemorações de $1^{\circ}$ de Maio. Seus autores são militares do Exército.

É lançado nos Estados Unidos, o primeiro ônibus espacial.

O papa João Paulo II é vítima de um atentado

\section{2}

Desativada formalmente a empresa Línea Arquitetura e Urbanismo.

\section{3}

A convite da CAPES, Gastão participa em Brasília de Reunião de Consultores de área da Pós-graduação em Arquitetura.

É realizado em São Paulo o Congresso de fundação da CUT (Central Única dos Trabalhadores). A Taça Jules Rimet, conquista brasileira na Copa do Mundo de 1970 é roubada no Rio.

\section{4}

Projeto da Residência Mirna Orlandi

É rejeitada pela Câmara a emenda constitucional que previa eleições diretas para presidente

\section{5}

Gastão participa em Atenas, como único representante brasileiro, do Congresso "FIRST CONSULTATION ON THE BUILDING MATERIALS INDUSTRY" com o tema Indústria de Materiais de Construção nos Países em Desenvolvimento. O arquiteto participou do conclave, como único representante brasileiro, com vistas a propiciar oportunidade de intercâmbios e estabelecer contato com Universidades que mantinham cursos da mesma natureza que a EESC.

Morre João Batista Vilanova Artigas, figura central da arquitetura paulista nas décadas de 60 e 70.

Morre Tancredo Neves, eleito presidente pelo voto indireto.

Mikhail Gorbatchov assume o poder na União Soviética e inicia uma série de medidas como a Glasnost (transparência política) e a Perestroika (reestruturação econômica).

\section{6}

Luiz Gastão apresenta um projeto de pós DOC e recebe em novembro o comunicado da Fapesp sobre o deferimento de sua bolsa. Se aposenta após 32 anos de atividade docente.

José Sarney, então presidente, suspende o pagamento dos juros da dívida externa por tempo indeterminado. 


\section{7}

Suspende contrato de trabalho com a UFSCar. Inicia programa de aperfeiçoamento científico no exterior - pós-doutorado na Escola de Arquitetura de Grenoble. No Instituto Eduardo Torroja em Madri trabalha com Julian Sallas, ocasião em que se tornariam grandes amigos.

\section{8}

Ao retornar da Europa, é contratado como professor assistente doutor da Faculdade de Arquitetura, Artes e Comunicação da UNESP em Bauru onde fica até 1996.

\section{0}

Participa da Comissão de Sinalização da Expo Unesp realizada de 13 a 16 de setembro de 1990

Recebe carta do prefeito de Bauru Eng Antonio Izzo Filho convidando-o a integrar a Comissão Assessora para as providências preliminares do projeto do Teatro Municipal de Bauru.

Fernando Collor de Mello é eleito presidente da República pelo voto direto, depois de 30 anos de eleições indiretas. Ao assumir, lança o desastroso Plano Collor.

A Alemanha é reunificada.

Nelson Mandela é libertado na África do Sul e Margaret Thatcher renuncia ao cargo de primeira-ministra na Grã-Bretanha.

Quatro anos depois, Fernando Henrique, o pai do Plano-Real, é eleito presidente e Mandela tome posse como primeiro presidente negro da África do Sul.

\section{5}

Recebe homenagem na Câmara de Vereadores de São Carlos. Se diverte com o equívoco de algumas congratulações recebidas, que atribuem ao arquiteto o título de "Engenheiro do Ano". Viaja à Europa e Estados Unidos onde visita e registra as obras de Frank Lloyd Wright e Charles Rennie Mackintosh. Se aposenta definitivamente deixando a Universidade Federal de São Carlos.

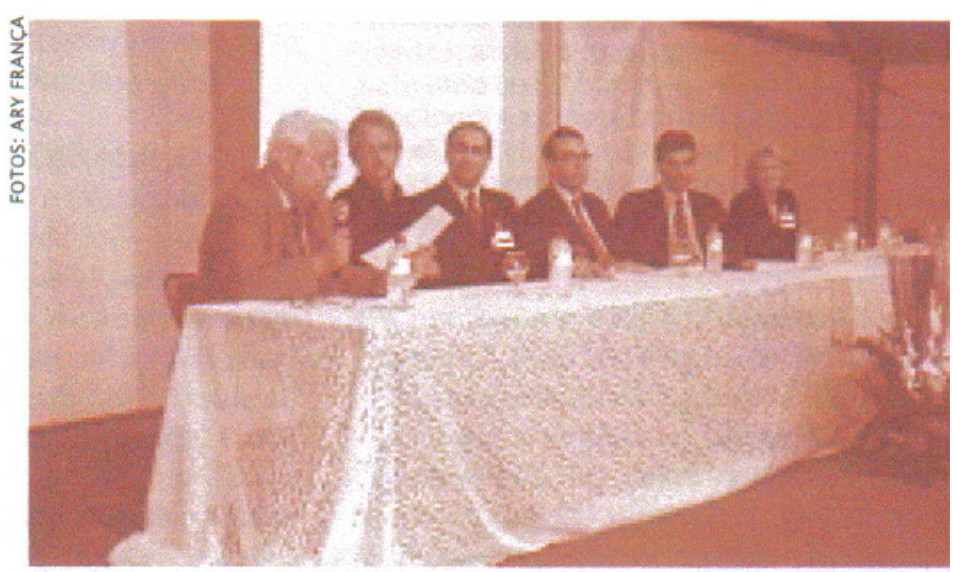

Abertura histórica - Solenidade de abertura do $3^{\circ}$ Congress à mesa (da esquerda para a direita) Gastão Castro Lima,

o homenageado, Henrique Cambiaghi, Haroldo Pinheiro, Gilber Belleza, Carlos Martins (representando o governo municipal) e Elisabeth Bottamedi, presidente do núcleo de São Carlos Acima: Homenagem a Luiz Gastão de Castro Lima no $3^{\circ}$ Encontro Regional de Arquitetos em São Carlos, em 2003. Fonte: Boletim IAB. Abaixo: Sala Professor Luiz Gastão de Castro Lima. LIEP.DEP. UFSCar. Homenagem recebida em outubro de 2006

\section{6}

Já aposentado, Gastão dá uma aula em forma de depoimento na EESC, onde conta sobre a criação da escola e sua trajetória profissional.

\section{7}

O Senado aprova a reeleição para presidentes da República, governadores e prefeitos.

\section{0}

Os 500 anos do Descobrimento do Brasil são comemorados com festa em todo país. Em São Paulo, as comemorações terminam em conflito entre policiais e manifestantes, índios e trabalhadores sem terra.

É mapeado o genoma humano.

\section{3}

Luiz Gastão recebe homenagem do IAB em São Carlos.Vem a falecer em 3 de dezembro, aos 76 anos de idade 
ANEXO 2

CRONOLOGIA DE PROJETOS 


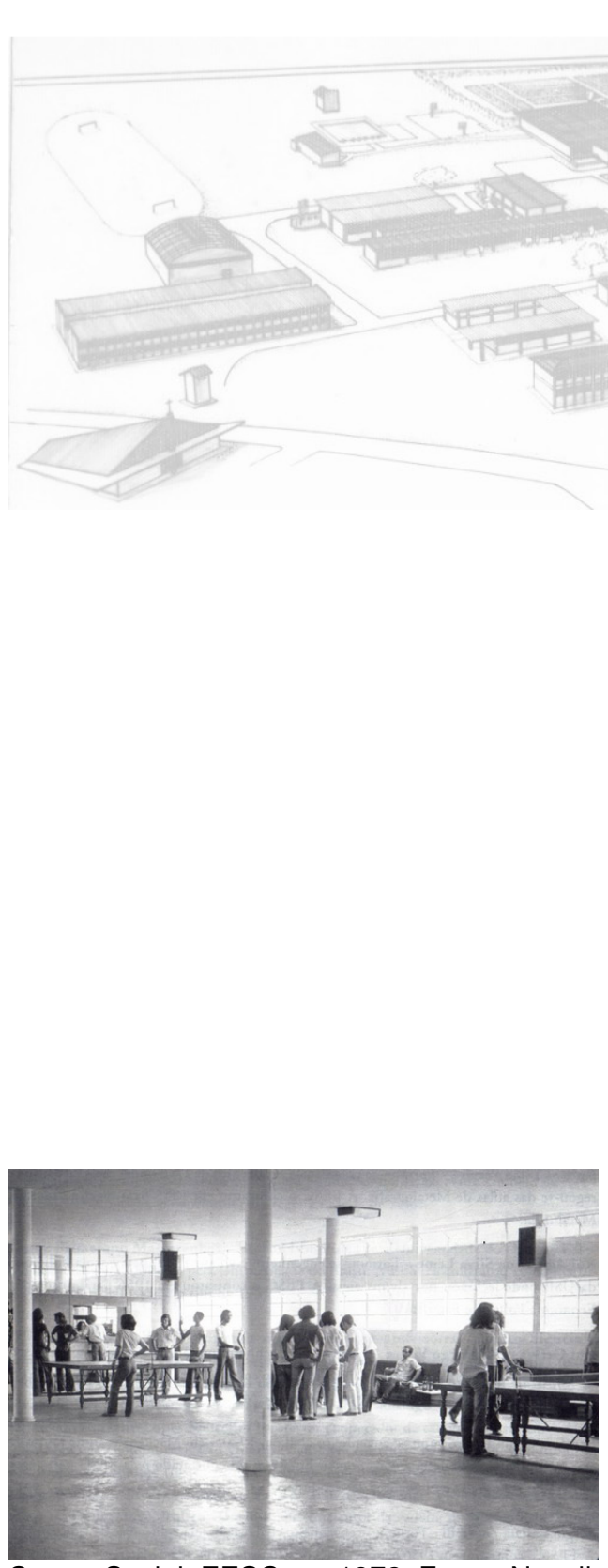

Centro Social. EESC em 1972. Fonte: Nosella (2000) p. 53

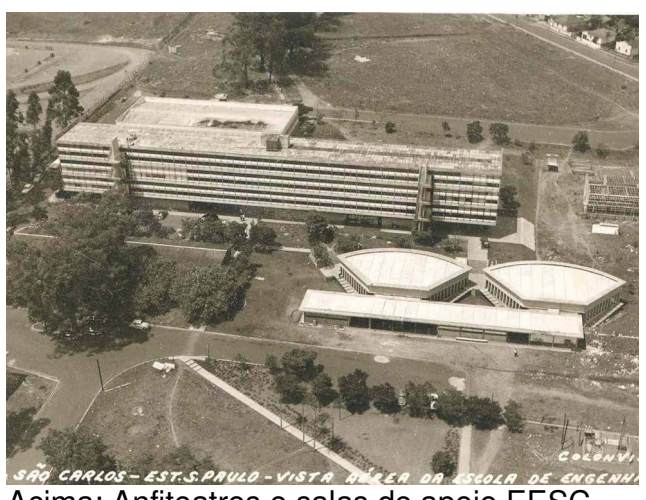

Acima: Anfiteatros e salas de apoio EESC-

USP em 1967. Fonte: Fundusp

\section{1}

Residência Eduardo Pellegrini. Rua Curitiba, 171. São Paulo (demolida) Laboratório de Análises clínicas $\mathrm{Dr}$ Gastão Fleury Silveira. Rua Cincinato Braga, 282. São Paulo

\section{de 1961 a 1964}

Anfiteatros e salas de aula EESC-USP. São Carlos Restaurante e Centro Social EESC-USP. São Carlos

Habitação dos alunos EESC-USP. São Carlos

Reforma do prédio para o Centro de Processamento de dados . EESCUSP . São Carlos

\section{2}

Casa Lia em Araraquara (autoria atribuída ao arquiteto pelo artigo Arquitetura Moderna em Araraquara de Eduardo Lauand Sobrinho, Francisco José Santoro e René Antonio Nusdeu. Apresentado no DOCOMOMO (sem data) disponível em:

http://www.docomomo.org.br/seminario\%203\%20pdfs/subtema_A2F/Ed uardo_lauand.pdf

1963

Anfiteatros e Departamentos de Mecânica da ESALQ. Piracicaba

\section{4}

Biblioteca Central da ESALQ. Piracicaba

Trabalhos de desenho Industrial junto à empresa Diamantul (ferramentas diamantadas) São Carlos

\section{5}

Prédio do Centro de Energia Nuclear (CENA) ESALQ. Piracicaba Centro de Estudos de Solos ESALQ. Piracicaba

\section{6}

Igreja Nossa Senhora de Fátima. Vila Pureza. São Carlos

Sede de campo do São Carlos Clube em sociedade com Admir Basso, Ricardo Martucci e Itamar Amador: administração, portaria, salão social e auditório (este último não construído) São Carlos

Casa Wilson Senise Rua Padre Teixeira nํ 1457

\section{7}

Planejamento, pré-fabricação e paisagismo na Fazenda Sapé. São Carlos

Clube Municipal de Guaira

Casa Nelson Onishick na Rua Paulo Botelho Sampaio n 441

\section{8}

Residência José Celso Contador na Rua Conde do Pinhal no 1756

Hospital São Marcos. Jaboticabal

Casa Silvio Montmorency Ernfrid Frick no 455

Casa Nilson Gandolti Rua Adolfo Catani $n^{\circ} 1356$

Casa Rua Marry Junior no 168 . Jaboticabal

Casa Jamil Sader. Rua Antonio Ruette no 777, Nova Jaboticabal. Jaboticabal - SP 


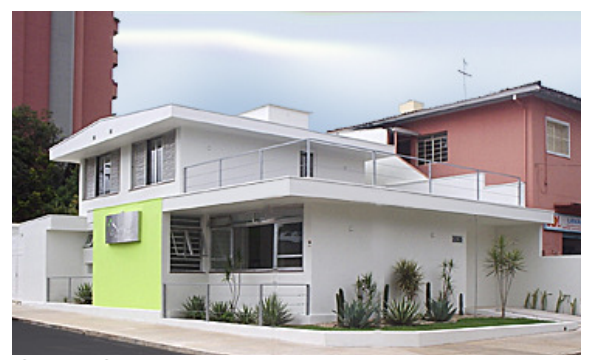

Casa Censoni. Abaixo como era originalmente. Acima, após reforma em 2006. Fonte: Mori \& Kako Arquitetura
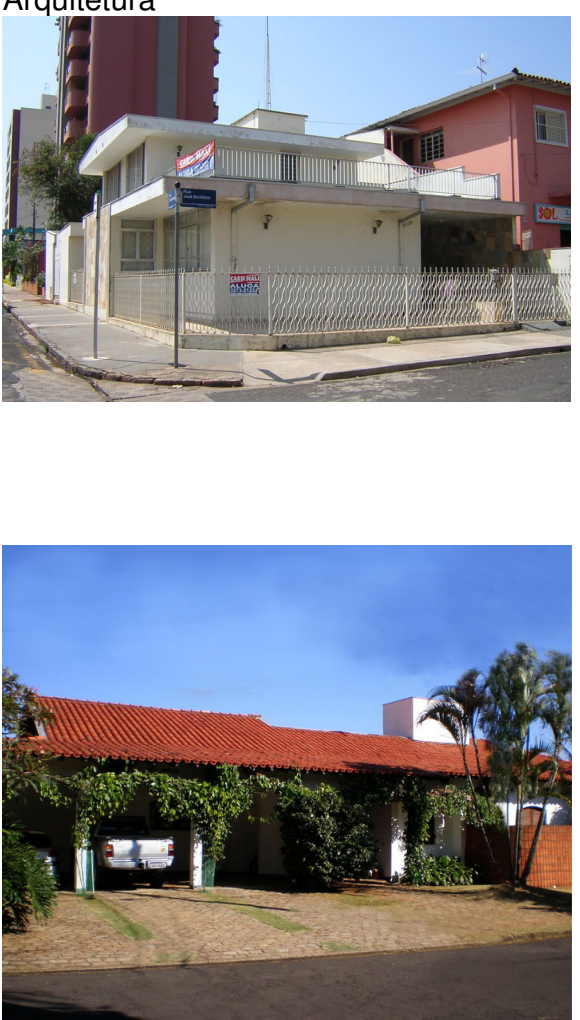

Casa Eugênio Cardinalli. Foto da

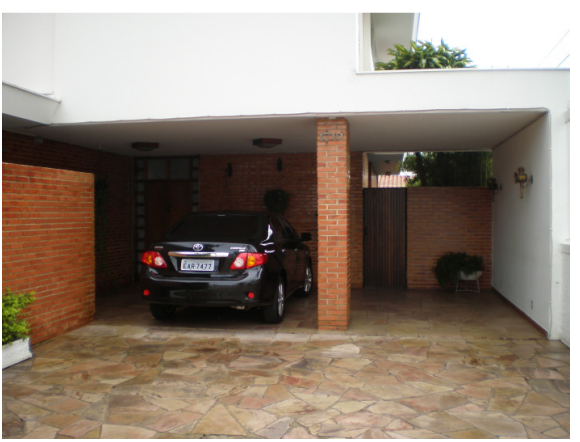

Casa Miguel Abdelnur Filho. Foto da autora

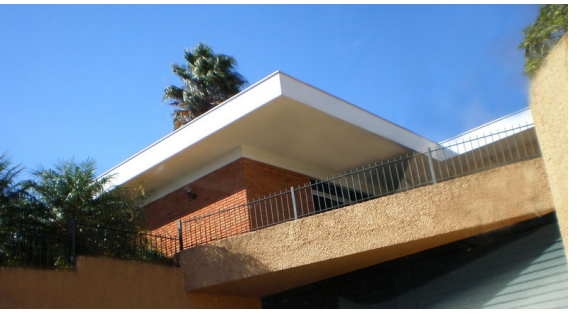

Casa Luiz Gonzaga. Fonte: foto da autora
1969

Biblioteca Central da EESC. São Carlos

Departamento de Matemática. EESC . São Carlos

Casa Miguel Abdelnur Filho. São Carlos

1970

COE - Centro Odontológico Especializado - São Carlos

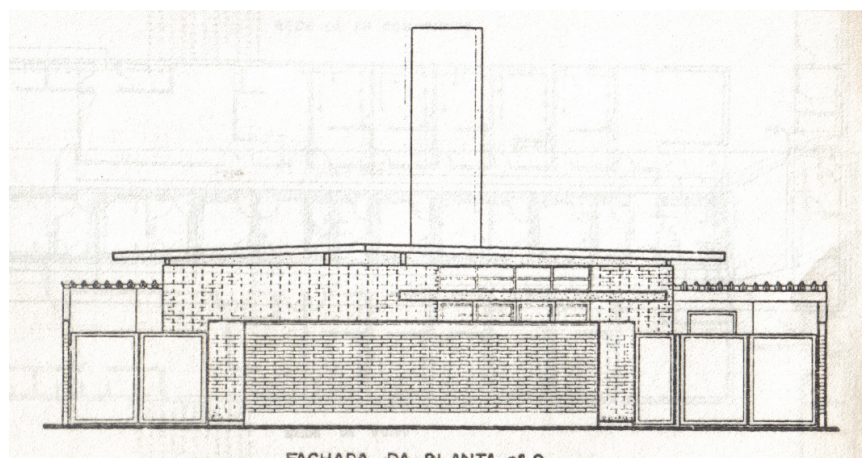

COE. Centro Odontológico especializado. Fonte: PORTO (1975)

1971

Desenvolvimento de Logomarca para a empresa COCIBRA-Companhia Brasileira de Construções Civis S.A.

Trabalho de Desenho Industrial e Comunicação Visual para a empresa SAMBRA/AS (Sociedade anônima de mármores) - Projeto de utilidade doméstica em mármore

1973

Casa Aldo ventura na Rua Rafael de A. S. Vidal $n^{\circ} 2337$

Casa na Rua XV de Novembro, 714

Casa na Orlando Damiano, 2412

Casa do Arquiteto. Rua Visconde de Inhaúma

1974

Casa Guilherme Kleber Marconi na rua Ernfrid Frick

Casa na Rua São Sebastião $n^{\circ} 319$

Casa na Rua Serafim Vieira de Almeida $n^{\circ} 183$

Casa Álvaro e Lucia Rizzoli na Rua Ernfrid Frick no 720

Casa na Rua XV de Novembro, 904

Casa na Rua XV de Novembro, 826

Fábrica Sanyo . Manaus

1975

Fábrica da Wirth Latina na Rua Rio Amazonas,479. Jockey club. São Carlos

\section{6}

Casa Leni Corsi na Rua José Gonçalves Carneiro, no 701

Casa na Rua XV de Novembro $n^{\circ} 620$

Casa na Rua XV de Novembro, 656

Casa Ernesto Pereira Lopes na Rua Mal Deodoro n 1325

\section{7}

Casa Wilson Nazari na Rua Madre Saint Bernard n 620 

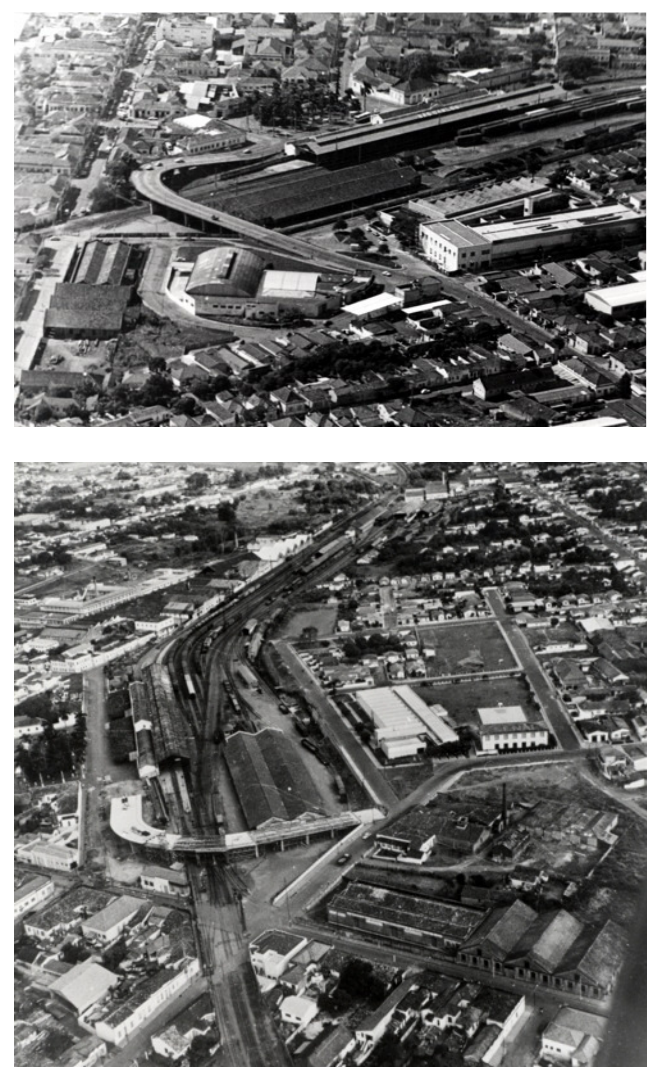

Passagem de nível sobre trilhos da ferrovia. Fonte: Fundação Pró Memória de São Carlos

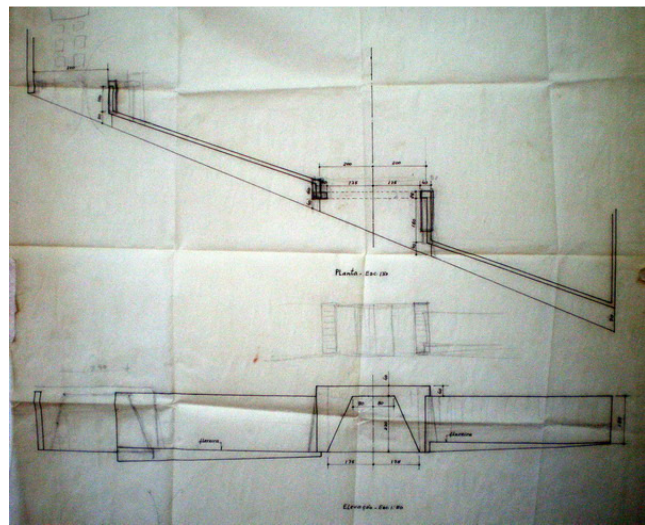

Croquis Casa Mirna Orlandi. Fonte: arquivo pessoal Mirna Orlandi.
1978

Casa Augusto Nastri - Rua Maestro João Sepe $n^{\circ} 763$

Casa Hungai na Rua Princesa Isabel $n^{\circ} 280$

\section{9}

Casa Ítalo Cardinali na Rua Urano Martins n 445

1980

Casa Eudemir Blanco na Rua São Sebastião n` 900

Casa Esenhower de Alcântara. Rua 24 lotes 6 e 7 Q 73 Jd Santa Felícia (Línea Arquitetura)

\section{1}

ongeng

Casa Odney Sebastião Martins. Rua Maestro João Sepe n 501

\section{2}

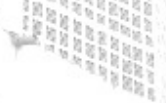

Casa Dario Rodrigues. Rua Paulino Botelho $n^{\circ} 881$

Casa Rua Madre Saint Bernard n 1000

\section{3}

Casa Ari Pedroso. Rua São Sebastião n²480

Casa na Rua Mal Deodoro $n^{\circ} 2681$

Casa Benedito Sacomano na Rua Mal Deodoro ${ }^{\circ} 2890$

\section{4}

Casa Rua Princesa Isabel $n^{\circ} 330$

Casa Mirna Januária Leal G. Orlandi. Rua Prof Nelson Montmorency, Jardim Cardinalli. São Carlos

\section{Projetos sem data}

Passagem de Nível sobre trilhos da ferrovia: Projeto arquitetônico e urbanização. São Carlos

Laboratório Pasteur - São Carlos

CGO Rua São Sebastião com D Pedro

Casa Maria Isabel de Castro Lima - São Carlos

Casa Marília de Castro Lima - Mogi das Cruzes

Clínica Dr Joaquim Portugal

Fábrica de Papéis em Birigui

Casa na Rua Maestro João Sepe

Casa na Rua Marechal Deodoro

Casa na Rua São Joaquim

Condomínio Parque Sabará - São Carlos

Casa na Rua Mário Correa

Casa da fazenda de Ronald Golias

Tulha e casa da Fazenda Dr Roberto Verzola

Casa Luis Pereira Lopes

Casa Dr Mário Augusto Conti na Rua Oscar Jensen, 220

Casa Peter Sicora

Casa Cano

Casa Eugênio Cardinali Jr

Casa Celso Garcia

Casa Vamberto Vanzo na Rua São Sebastião no 413

Casa João Gilberto Bortoloti na Rua São Sebastião, n 413

Casa Dr Luiz Gonzaga

Casa na Rua XV de Novembro, 1080

Casa na Rua XV de Novembro $n^{\circ} 715$

Casa Walter Rugai Rua Ernfrid Frick no 344

Casa na Rua Serafim V. A. $n^{\circ} 605$

Casa na Rua Américo Walter Ríspoli $n^{\circ} 509$

Casa Dr Fábio Porto

Casa na Rua Mal Deodoro n 1358 


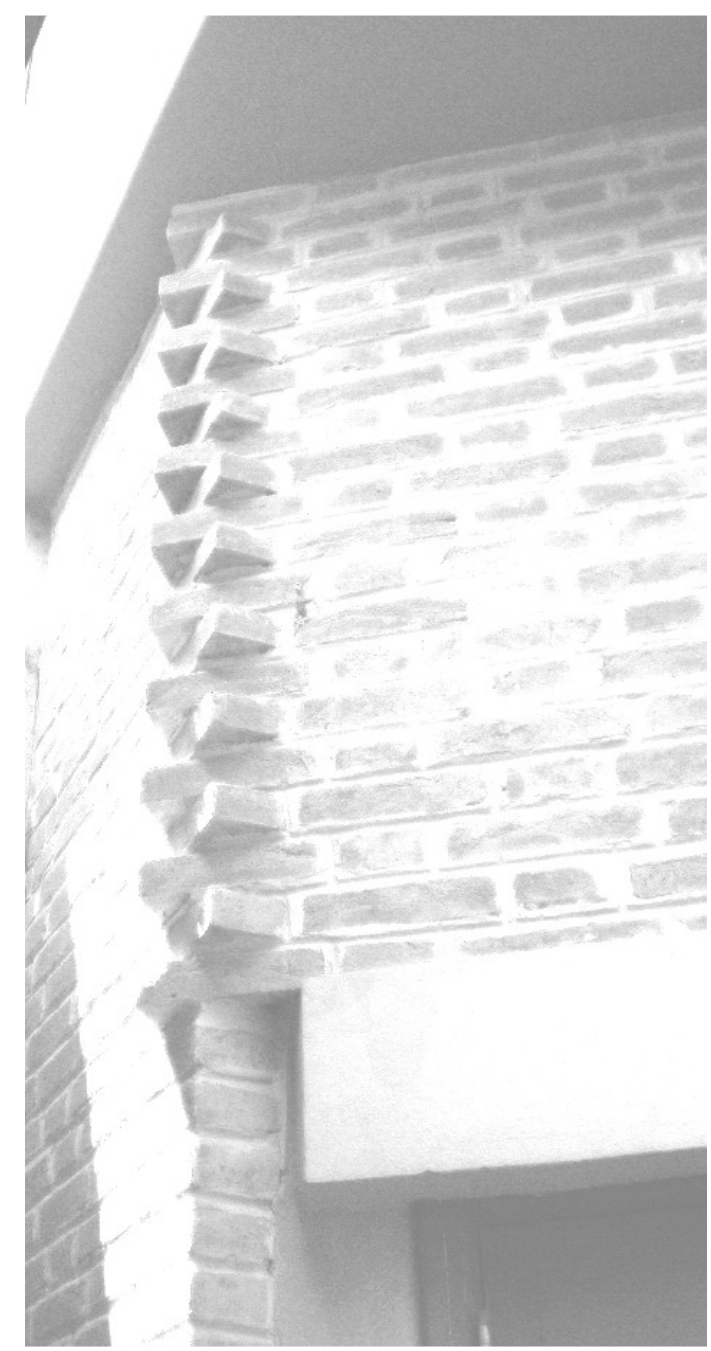

Casa na Rua Mal Deodoro $n^{\circ} 1030$

Casa na Rua Rafael de Abreu Sampaio Vidal $n^{\circ} 2411$

Casa Nélio Gaioto. Rua Antônio Rodrigues Cajado n²295

Casa Sérgio Ostronoff. Rua Antônio Luiz Cajado esquina com Rua Alfredo Lopes

Casa na Rua Rafael de A. Sampaio Vidal $n^{\circ} 2214$

Casa Censoni Rua São Sebastião

Casa Rua Dom Pedro II, no 1466

Casa em Mogi das Cruzes

LIEP. Laboratório do Produto. UFSCar

Fazenda Sertãozinho - Propriedade de João Luiz de Oliveira Pedroso. Trabiju-SP

Conjunto de Consultórios Médicos - Bauru.

Dr Márcio Matheus Tolentino, Tadashi Nishiyama e Antônio Pádua Leal Galesso

Rua Gustavo Maciel com Capitão Gomes Duarte

Casa em São Paulo - Próxima à Cardeal Arcoverde. Endereço não localizado. Projetada para um médico.

Esta relação foi elaborada a partir de informações colhidas junto à Fundação Pró-Memória de São Carlos, USP, ESALQ, UFSCar e a partir de depoimentos de ex-colaboradores, familiares, amigos e colegas de profissão. Também foram extraídas do currículo do arquiteto, que apontava apenas as consideradas por ele como mais relevantes. Não se trata, portanto, do conjunto completo das obras de Luiz Gastão de Castro Lima, apenas um primeiro levantamento. 


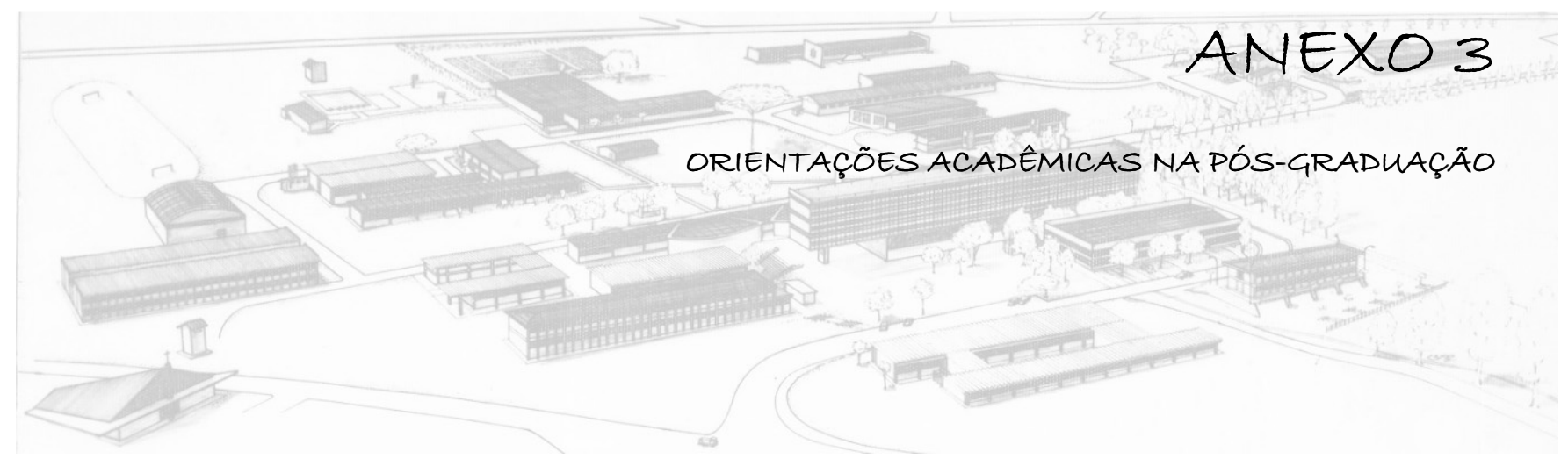

AMADOR Itamar Moraes. Urbano São Carlos: vinte anos de política urbana: 1960/1980. São Carlos, 1981. Dissertação (Mestrado). Escola de Engenharia de São Carlos. Universidade de São Paulo. $141 \mathrm{p}$.

Orientador: Luiz Gastão de Castro Lima

ANDRADE, Eliana Maria de. Proposta para integração urbana da faixa marginal lacustre a oeste de Maceió. São Carlos, 1982. Dissertação (Mestrado). Escola de Engenharia de São Carlos. Universidade de São Paulo. 80 p.

Orientador: Luiz Gastão de Castro Lima

BADARÓ, Ricardo de Souza Campos. O Plano de Melhoramentos Urbanos de Campinas, 19341962. São Paulo, 1987. Dissertação (Mestrado). Faculdade de Arquitetura e Urbanismo. Universidade de São Paulo.

Orientadores: Dr. Luiz Gastão de Castro Lima e Dr. Lafael Petroni.

BASSO, Admir. Considerações sobre as variáveis que interferem no relacionamento entre ruído de tráfego urbano e perturbação. São Carlos, SP, 1979. Dissertação (Mestrado em Arquitetura). Escola de Engenharia de São Carlos. Universidade de São Paulo.

Orientador: Luiz Gastão de Castro Lima

BORTOLUCCI, Maria Ângela Pereira de Castro e Silva. O Alto da Sé de Olinda, uma Proposta de Preservação. São Paulo, 1983. Dissertação (Mestrado em Arquitetura e Urbanismo). Faculdade de Arquitetura e Urbanismo. Universidade de São Paulo.

Orientador: Luiz Gastão de Castro Lima

BUSATO, Sérgio Luiz. Arquitetura Virtual: 0 uso do computador na confecção de maquetes eletrônicas. 1996. Dissertação (Mestrado em Projeto, Arte e Sociedade) Universidade Estadual Paulista Júlio de Mesquita Filho, FAAC UNESP.

Orientador: Luiz Gastão de Castro Lima

CAMAROTTO, João Alberto. Estudo das relações entre o projeto de edifícios industriais e a gestão da produção. São Paulo, 1998. Tese (Doutorado). Faculdade de Arquitetura e Urbanismo. Universidade de São Paulo.

Orientador: Luiz Gastão de Castro Lima.

CARVALHO, Rômulo Sérgio Soares de. Assimilação dos conjuntos habitacionais pela malha urbana da cidade: Estudo de caso conjunto Castelo Branco. São Carlos, 1986. Dissertação (Mestrado). Escola de Engenharia de São Carlos. Universidade de São Paulo. 155 p. Orientador: Luiz Gastão de Castro Lima

ESPÍRITO SANTO, Anaizi Cruz. Percepção visual na cidade de Pelotas: identificação e representação dos referenciais urbanos. São Carlos, SP,1987. 2v. Dissertação (Mestrado em Arquitetura).Escola de Engenharia de São Carlos, Universidade de São Paulo. 114 f.

Orientadores:Luiz Gastão de Castro Lima e José Cláudio Gomes 
ESTEVES JÚNIOR, Milton. Considerações sobre a compreensão e expressão da Cidade. São Carlos, 1990. Dissertação (Mestrado em Arquitetura). Escola de Engenharia de São Carlos. Universidade de São Paulo. 175p.

Orientador: Luiz Gastão de Castro Lima.

FERRARI, Marisa. Desenho básico como linguagem no ensino de engenharia enquanto instrumento de trabalho. São Carlos, 1986. Dissertação (Mestrado). Escola de Engenharia de São Carlos. Universidade de São Paulo.

Orientador: Luiz Gastão de Castro Lima

FIGUEIREDO, José Luiz Valero. Combinando tipos: uma aplicação da matriz da descoberta na programação visual. 1996. Dissertação (Mestrado em Artes e Comunicação) Universidade Estadual Paulista Júlio de Mesquita Filho. Orientador: Luiz Gastão de Castro Lima

FORTES Alzira Margarida Licht. Noções fundamentais sobre estruturas. São Carlos, 1986. Dissertação (Mestrado). Escola de Engenharia de São Carlos. Universidade de São Paulo. 333 p.

Orientador: Luiz Gastão de Castro Lima

GOIS, Ronald Lima de. Natal crescimento urbano através de conjuntos habitacionais. São Carlos, 1982. Dissertação (Mestrado). Escola de Engenharia de São Carlos. Universidade de São Paulo. 84 p.

Orientador: Luiz Gastão de Castro Lima

GONÇALVES, José Luiz. Reforma de residências para deficiente físico em cadeira de rodas.

São Carlos, 1982. Dissertação (Mestrado). Escola de Engenharia de São Carlos. Universidade de São Paulo. 251p.

Orientador: Luiz Gastão de Castro Lima

LAURENTIZ, Luis Carlos de. Considerações sobre a preocupação social na arquitetura moderna no Brasil das origens a 1945 no eixo São Paulo-Rio de Janeiro. São Carlos, 1986. Dissertação (Mestrado). Escola de Engenharia de São Carlos. Universidade de São Paulo. 208 p. Orientador: Luiz Gastão de Castro Lima

MENECHINO, Luís Antônio Parreiras. Restauração da Antiga Casa de Câmara e Cadeia de São José do Rio Pardo, SP. São Carlos, 1986. Dissertação (Mestrado em Arquitetura). Escola de Engenharia de São Carlos. Universidade de São Paulo.

Orientador: Luiz Gastão de Castro Lima

MERCADANTE JÚNIOR, Carlos Maurício Dias: Levantamento das Características Arquitetônicas de Ribeirão Preto, 1856 - 1960. São Carlos, 1988. Dissertação (Mestrado em Arquitetura). Escola de Engenharia de São Carlos. Universidade de São Paulo.

Orientador: Luiz Gastão de Castro Lima

MIGUEL, Jorge Marão Carnielo. Casas projetadas por Rino Levi: um estudo de concepção espacial. São Carlos, 1985. Dissertação (Mestrado). Escola de Engenharia de São Carlos. Universidade de São Paulo. $137 \mathrm{p}$.

Orientador: Luiz Gastão de Castro Lima

MORENO ESTRADA, Violeta Margarita de Jesus. Conceituação e pré-figuração de sistemas reticulares: a linguagem conceitual de um módulo triangular na prática de ateliê. São Carlos, 1989. Dissertação (Mestrado). Escola de Engenharia de São Carlos. Universidade de São Paulo. 223 p.

Orientador: Luiz Gastão de Castro Lima

NOGUEIRA, Spencer de Morais Pupo. Ocupação Ecológica da Amazônia. São Carlos, SP, 1983. Dissertação (Mestrado em Arquitetura). Escola de Engenharia de São Carlos. Universidade de São Paulo.

Orientador: Luiz Gastão de Castro Lima

OLIVEIRA, Ana Lúcia Costa de. Estudo da metodologia de abordagem da reciclagem de prédios. São Carlos, 1985. Dissertação (Mestrado). Escola de Engenharia de São Carlos. Universidade de São Paulo. 137 p.

Orientador: Luiz Gastão de Castro Lima 
OLIVEIRA, Eslo Glacy de. Metodologia para o projeto arquitetônico. São Carlos, 1979. Dissertação (Mestrado). Escola de Engenharia de São Carlos. Universidade de São Paulo.

Orientador: Luiz Gastão de Castro Lima

PIZZIGATTI, Clemencia Pecorari Arte na formação do terapeuta ocupacional. Contribuição ao ensino da arte-educação para o curso de terapia ocupacional. Piracicaba: 1990. 278 f. BBE. Dissertação de Mestrado em Filosofia da Educação - Universidade Metodista de Piracicaba. Orientador: Luiz Gastão de Castro Lima.

RAIOL, José de Andrade. Arquitetura hospitalar: alternativas e informações no processo de escolha de unidade de internação hospitalar. São Paulo, 1979. Dissertação (Mestrado). Faculdade de Arquitetura e Urbanismo. Universidade de São Paulo.

Orientador: Luiz Gastão de Castro Lima

RODRIGUES, Celso Luiz Pereira. O dimensionamento de estações de trabalho e seus reflexos nas condições de segurança. São Paulo, 1993. Tese (Doutorado). Faculdade de Arquitetura e urbanismo. Universidade de São Paulo.

Orientador: Luiz Gastão de Castro Lima

ROLAND, Luiz de Franca. Expectativas significantes de usuários de um espaço determinado unifamiliar contido numa comunidade urbana média e a produção desse espaço enquanto arquitetura - a sala de estar. São Carlos, 1987. Dissertação (Mestrado). Escola de Engenharia de São Carlos. Universidade de São Paulo. 251p.

Orientador: Luiz Gastão de Castro Lima

RORIZ, Maurício. Zona de Conforto Térmico: um estudo comparativo de diferentes abordagens. São Paulo, 1987. Dissertação (Mestrado). Faculdade de Arquitetura e Urbanismo. Universidade de São Paulo.

Orientador: Luiz Gastão de Castro Lima

SANCHES, Suely da Penha. Contribuicao da metodologia de dinamica de sistemas para a construcao de modelos de planejamento urbano e regional. São Carlos, 1980. Dissertação (Mestrado). Escola de Engenharia de São Carlos. Universidade de São Paulo. 78p.

Orientador: Luiz Gastão de Castro Lima

SILVA, Francisco de Assis Gonçalves da. Clima e Habitação - Análise de conjuntos habitacionais de baixa renda na cidade de João Pessoa - Estado da Paraíba. São Paulo, 1986. Dissertação (Mestrado em Arquitetura). Faculdade de Arquitetura e Urbanismo. Universidade de São Paulo.

Orientador: Luiz Gastão de Castro Lima

SILVA, Sonia Lúcia Medeiros da. Casa da cultura em casa de detenção:considerações sobre a reutilização de um presídio do século XIX construído em Recife. São Carlos, 1981. Dissertação (Mestrado). Escola de Engenharia de São Carlos. Universidade de São Paulo.

Orientador: Luiz Gastão de Castro Lima

SOBENIS, Nadya Beatriz Soto. Conforto térmico na arquitetura habitacional. São Carlos, 1982. Dissertação (Mestrado). Escola de Engenharia de São Carlos. Universidade de São Paulo. 228p.

Orientador: Luiz Gastão de Castro Lima

YUNES, Gilberto Sarkis. Participação do contexto urbano na formação das reduções jesuiticoguaranis. São Carlos, 1987. Dissertação (Mestrado). Escola de Engenharia de São Carlos. Universidade de São Paulo. 167p.

Orientadores: Celso Monteiro Lamparelli e Luiz Gastão de Castro Lima

ZANI, Antônio Carlos. Repertório arquitetônico e sistema construtivo das casas de madeira de Londrina - PR. São Carlos, SP, 1989. Dissertação (Mestrado em Arquitetura). Escola de Engenharia de São Carlos. Universidade de São Paulo. Orientador: Luiz Gastão de Castro Lima 